
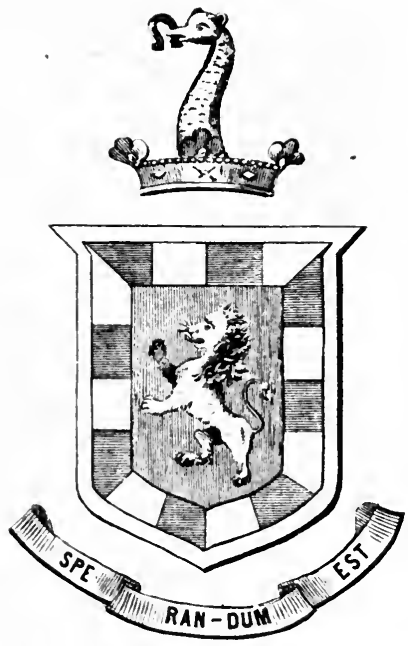


$$
\begin{aligned}
& \text { UCSB LIBRARY } \\
& x-63072
\end{aligned}
$$




$$
\text { - }
$$




\section{The Fuxal Srienre Sexies}

Edited BY I. H. BaIlex

\section{THE PRINCIPLES OF FRUIT-GROWING}




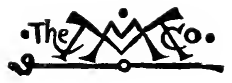




\title{
THE PRINCIPLES OF FRUIT-GROWING
}

\author{
BY \\ L. H. BAILEY
}

FIFTH EDITION

\section{New 12Tork \\ THE MACMILLAN COMPANY \\ LONDON: MACMILLAN \& CO., LTD. 1902}




\section{Copyright, 1897 \\ By L. H. BAILEI}

Set up and electrotyped June, 1897

Reprinted July, 1898; July, 1900; July, 1901

and June, 1902 


\section{PREFACE TO THE SECOND EDITION.}

IT is nearly a year since I left this work with the printer. The first copy of the book which I saw was procured in a foreign land; and now that a second edition is called for, I find myself again in fields and orchards of another country. These personal remarks are not of themselves worth making here; but they shall be my excuse for writing a few contrasts of American and European fruit-growing.

Classified in respect to the objects in view, there are two kinds of fruit-growing, - that which desires the product primarily for home use, and that which desires it primarily for market. Of market or commercial fruit-growing, there are again two types,that which aims at a special or personal market, and that which aims at the general or open market. The ideals in these two types of fruit-growing are very unlike, and the methods and the varieties which succeed for the one may not succeed for the other. The man who grows fruits for the special market, has a definite problem. The product is desired for its intrinsic qualities; and special products demand special prices. The man who grows fruit for the world's market, has no personal customer. The product is 
desired for its extrinsic or market qualities; and the world's products bring the world's prices. The special-market fruit-grower generally works on a small base. The world's-market fruit-grower works on a large base; or he sells to another who, by combining similar products of many persons, is able to command the attention of the market.

Now, it is the large. base upon which American fruit-growing is established which enables it to enter European markets. In America are thousands of acres of one variety, and the conditions under which the fruits are grown are so similar as to produce uniformity in the product. We speak one language, and, although we are two nations, we live in practically the same political environment. We go to Europe, and to our own great markets, with wholesale quantities.

In Europe, on the contrary, nearly every fruitgrowing center is unique. The industry is the outcome of years, may be of centuries, of local effort and tradition. There is no general uniformity of methods and varieties. Community of interests on a large base is impossible. There are insurmountable difficulties of physiography, of races, languages and political systems. In the staple products, the European grower may not be able to compete with Amerieans in his own markets, so long as those markets remain naturally open.

The American fruit-grower quickly assimilates new methods. He is unfettered by tradition; and how much this means only those can understand who know 
the European customs and ideals. $\mathrm{He}$ is bold and confident. He easily buys and sells land. He controls his own efforts and destinies. He has more help from teachers and experiment stations than the European has. A single instance will illustrate all this. Spraying for fungous diseases is a European development, whereas large-area spraying for insects is an American development. The American has assimilated the spraying for plant diseases and has made improvements in the machinery, while he has at the same time made equal progress in fighting insects; but the European has not assimilated the American methods of handling insects, and spraying for plant diseases is probably less generally understood than in America.

In many parts of Europe, the farmer is a tenant, and he therefore has little interest in planting trees. But even if he owns land, the area is usually small, notwithstanding the fact that there are many very large individual plantations. There are few great geographical regions which are adapted to fruit-growing, or which, if they are adapted, can be utilized for that purpose. The environments of the Old World farmer are relatively inflexible. The result is that his methods tend to become stereotyped and rigid. He lacks the inspiration which comes of conditions which are easily recast and modified. His small areas must be so crowded with many kinds of plants that machinework is impossible. There are few orchards in Europe, as that word is understood in America, meaning an area devoted exclusively to tree fruits set at regular 
distances and cultivated systematically with laborsaving machinery.

For these and other reasons, as well as for the fact that our fruits and their manufactured products are attractive and of good quality, I believe that the American fruit-grower will find an increasing market in Europe. But the greater the quantity sent abroad, the more discriminating will that market become; and it must be true that the brands and the varieties of inferior quality tend to supply the inferior markets.

But if I believe that American fruit-growing is in advance of the European in its general commercial aspects, I am equally convinced that the European is in advance in growing for special and personal uses. The narrowness of the enterprises, the competition in restricted areas, the respect for traditional methods and varieties, conserve the very elements which appeal to the discriminating consumer, while, at the same time, they develop great skill in the fruit-grower. The care which is bestowed on individual plants, the niceties of exposure and of training, the patient handwork, may almost be said to develop personal traits in the fruits themselves. Such fruits may not find a place in the open market, but for that very reason they may have a higher commercial value.

At the head of a little valley, closely shut in by the $A l p s$, is a famous apple orchard. The trees are trained upright on the opposite sides of a double espalier or trellis, the sides of which are less than two feet apart. In each of these rows, the trees are two to four feet asunder. These trellises are perhaps ten feet 
the one from the other, and between each two is a row of apples on cordons or single horizontal wires; and in the spaces potatoes or other annual crops are often planted. Even the wires that brace the end posts of the trellises have apple trees trained on them like strands of vines. Each tree is trained to a definite number of branches or arms, and even the fruit-spurs are carefully determined. This plantation is the property of a company whose business it is to care for the land and the trees, and to find a market for the fruit. It is expensive to grow apples in this way; but the best Calvilles often bring a gulden (about forty-one cents) apiece.

Perhaps the most important lesson which the American fruit-grower has yet to learn is the fact that there are two types of effort in commereial fruitgrowing, and that there may be pecuniary reward in fruits which are unknown in the market. Failure to distinguish these two categories is the result of a confusion of ideas. One grows fruit either for a special and personal market, in which case he looks for his own customer and is independent of general trade; or he grows what the market demands, and allows the machinery of trade to handle the product. In the latter effort, the American fruit-grower is preëminent; but in the former he has made little more than a beginning.

Bozen, Trrol, May 20, 1898.

\section{H. BAILEY.}




$$
\text { - }
$$




\title{
CONTENTS
}

\author{
CHAPTER I.
}

INVENTORY OF FRUITs. Orchard culture or tree-fruit culture-Pomaceous fruits-Drupaceous or stone fruits-Citrous fruits-Moraceous fruits-Anonaceous fruits-Myrtaceous fruits-Sapotaceous fruits-Anacardiaceous fruits-Ebenaceous fruits-Leguminous fruits-Nut-fruits-Palmaceous fruits-Miscellaneous tree-fruits. - Vine-fruit culture-Viticulture-Passifloraceous fruits. - Small-fruit culture-Rubaceous fruits-Ribaceous fruits-Miscellaneous bush-fruits -Strawberry culture-Cranberry culture.-Non-woody or herb-like fruits-Musaceous fruits-Pineapple-Cactaceous fruits-Miscellaneous herb-like fruits . . . . .

The geography of Fruit-growing. The temperature determinant-The moisture determinant-The soil determinant-The parasite determinant . . . . . .

The course of evolution of a Frutt-Region. .

ThE oUtLOOK For FRUIT-Growing. The two factors concerned-Farmers do not become rich-Always a demand for the unlike-Choice of business is a matter of taste and capital-Farmer must master his local conditions-The fruitgrower, thcrefore, must be trained-Best farmers are often not brought up on the farm-The farmer is his own business manager-Outlook best in those fruits which make the greatest number of secondary products. - Is there over production of fruit?-Insufficient distribution-Tendency must be for cheaper fruit-Normal failure of many plantations. . 


\section{CHAPTER II.}

THE PLACE. The geography of a fruit farm-Choiee with reference to markets and frosts. - Location with reference to market-Importanee of transportation facilities-The personal markets.-Location with reference to frosts-Frosts and freezes-Proximity to bodies of water-Nature of the influence of lakes-Retardation of bloom-Eleration and frost-Climate held responsible for too much-The declining peach areas. - Winds and air-currents in relation to fruityrouing-High and rolling lands-High winds to be avoided -Effeets of winds in drying up land and plants-Low windbreaks to lessen eraporation.-A tmospheric drainage-The currents of air-Cold and dense air settles in low placesThe frosty belt below a wood-Very small objects intercept movement of cold air-Temperatures of high and low stations.

The site for the FRIIt plantation. Elevated sites usually better-The exposure.-The aspect-North and south slopes. . . . . . . . . . . .

WiNd-BREAKs fOR FrUit plantations. Tabulated opinions of fruit-growers-Epitome of benefits of wind-breaksExperiences adverse to wind-breaks.-Statements of authors - Wind-breaks for many kinds of fruits and in various parts of the country.-Forests and fruit-grouing-Influenee upon wind and moisture-Its relation to inseets and diseases.Reriew of the influences of wind-breaks upon fruit plantations - What winds it is desired to break - Winds from bodies of water-The effect of a wind-break upon winds.-Position of the wind-break with reference to the fruit plantation-The prevailing winds-Opinions of fruit-growers. - How to make the $u$ ind-break-Kinds of trees-Opinions of fruit-growersConclusions.-General summary upon wind-breaks-Condensed statements of benefits and injuries . . .

Protecting plantations from frost. Mulching to enable plants to escape frost-Experiments at Ithaea-Mulching strawberries-Conclusions. - Corering plants for protectionMethods of covering-Laying down blackberries and raspberries-Protecting peach trees.-Adding vapor of uater 
to the air-Irrigating and flooding-Spraying for frost-Tilling-Systematic evaporation 'of water in orchards.-The making of smudges - Characteristics of a good smudge-Materials to use-Spraying the smudges-An account of European experience.-Making currents of air-Heating the air - Use of large fires . . . . . . . .

THE PREDICTION OF FRost. Records of frosts-Frost charts-The psychrometer-Finding the dew-point.

$121-131$

\section{CHAPTER III.}

The Tillage of Fruit Lands. . . . . . 133-174

Evolution of tillage-Apparently contrary to nature-Comparison with the forest-Weeds-Neglect of apple orchards.

THE PHILOSOPHY OF TILLAGE. Three main objects of tillage. - The texture of the soil-Physical conditions more important than mere plant-food.-The moisture of the soilDrought and rainfall-The moisture reservoir-Fall plowing - Tillage to save moisture-The earth-mulch.

USE OF THE VARIOUS TOOLS IN RELATION TO CONSERVATION of Molsture. Plowing to save moisture-The test of good plowing.-Harrowing to save moisture-The springtooth harrow-The acme harrow-The disc harrows-The smoothing harrows.-Cultivators and conservation of moisture-Level culture $\mathrm{ss}$. ridge culture.-The roller in its relation to soil moisture-Difficulty of using the roller properly-Its relation to seeding-Should be followed by tillage . 145-154

SugGestions FOR THE TILLING OF FRUIT LANDS. Draining-Subsoiling-Preliminary preparation of land for fruit plantations-The plowing of the orchard-Level cultureThe tools-Harnesses-The tillage in the early and late years of the orchard. - Specific remarks -1 , Begin to till when the orchard is planted, and till the entire surface-The deep rooting of trees -2 , Tillage should be begun early in the season, in orchards-The early growth of trees-3, Tillage should generally be stopped in late summer or very early fall-4, Till in such manner that the land may be in uniform fine tilth5, Tillage may be orerdone-Too rapid growth . . . 154-169 
Cropping the orchard. The open space about the treePages The kind of erops for an orcharl-Nursery stock in fruit plantations-Sod in the orchard-Fallowing the orchard

\section{CHAPTER IV.}

The Fertilizing of Frut Laxds . . . . 175-223

Plants will grow without fertilizers-Profit may lie in nsing additional plant-food, however-Humus-Formation of soils-Weeds.

THE LESSON OF NCRSERY LANDS. Injuries to such landsSource of fertility in soils-Man's treatment of the landThe features of the nursery lands - The conclusions respecting the depletion of nursery lands . . . . . . . 178-183

Cover crops. What they are-Objects of their use-Experiments with covers at Cornell.- The kinds of cover crops -A local question-Rye-Corn, buckwheat and cereals-Peas and beans-Cow pea-Veteh-Crimson Clover-Analyses . 184-202

Fertilizing the freit plantation. Trees vs. annual crops-Plant-food taken up by trees-Effects of the various elements-New Jersey experiments in fertilizing peaches.Stable manure-Rotation in manures-Danger of over use of barn manures. - Chemical fertilizers-Nitrogen-PotashPhosphoric acid-Recommendations by Voorhees.-Summary statement . . . . . . . . .

\section{CHAPTER V.}

The Plantixg of Fruit Grounds . . . . . $224-276$

THE cholce of varieties. A personal question-The mental ideal-1, Follow personal preferences-2, Obtain a specific ideal of the purpose for which the fruit is to be grown-3, Do not covet rarieties of other geographical regions -4 , Choose with reference to local environment -5 , Choose with reference to inter-pollination-The mixing of varieties-Lists of self-fertile and self-sterile varieties -6 , The choice should be aided by inquiry of many persons and accessible writings 
The SELection of the plants. What is first-elass stock? PAges -Age at which to buy.-Dwarfs vs. standards-The parentage of the stock may affect its value-Buying the treesPeddlers-Near-by nurseries . . . . . . .

The setting of the plants. When to plant-Fall vs. spring-Stripped trees.-Distance apart-The mixing of species, or double planting-The opinions of Van Deman.How to plant the stock-Preparing the land-Making the holes-Mulching-Puddling.-Trimming the trees-The two ideals-Illustrations of methods-Trim after planting-Trimming fall-set trees . . . . . . . .

The laying out of the fruit plantation. Surveying the land-The corn marker-Tree placers. - To lay out with the plow-Laying out with a line-Another line methodStaking methods-Orchard plans-The hexagonal or Van Deman plan-The alternate plan-The Wellhouse planThe Parker Earle plan-The Olden plan-Hale and Olden plans for peach orchards.-The family fruit plantation . $237-254$ 


\section{CHAPTER VII.}

PAges

Diseases, Ixsects AND SPRAyixg.

Historical contrast respecting spraying-Secondary results of the spraying idea-Calls attention to pests-Forces new ideals - Will bring in some of the discarded varieties-Forces a eloser study of companionships of pests and erops, and of rotations-Will take its place as one of the cardinal operations of fruit farming-Will force better care of the plantation-Will make the grower more watchful-Will enlarge his horizon-Classification of pests and diseases-Insects-Parasitic fungi-Physiological and germ diseases-Borers-Rootgalls-Injuries by hail-Bagging.

SPECIFIC ReMarks cPoN SPRAYING. 1, Spraying is only one of the requisites to success in fruit-ruising-2, spraying is an insurance-3, Spraying is of some value every year. upon apples, pears, plums, quinces, grapes and varions other. fruits-4, Spray thoronghly, or not at all-5, Prepare for next year's work during the winter-6, The style of pump aud nozzle to use depends almost wholly upon the particular. kind of work to be done-7, The furmer should know what he wats to kitl bcfore he begins to spray-8, The time to spray must be determined for each particular case-9, Prepare stock solutions for the Bordeaux mixture, vather than to make each batch in the quantities called for by the formula10, How can one tell if soluble arsenic is present in Paris green?-11, How can one determine if Paris green is pure? -12 , What becomes of the arsenic when it falls upon the soil?-Summary.

. 353-37

\section{CHAPTER VIII.}

Harvesting and Marketing Freit . . , , 378-4i9

Pickixg freits. When to pick-Long-keeping and ripeness-Apples-Pears-Peaches and apricots-Cherries and plums.-How to pick-Pick by the stem-Leave the stem on - Fruit is picked in temporary reeeptacles-Ladders-Fruitpickers-Keep fruit away from the sun--Keeping records with the pickers-Necessity of hand-picking. 
The PaCkING OF FRUIT. What is first-class fruit?-Importance of uniformity in size.-How to pack-The tiers or layers of fruit-Facing fruit in barrels-Packing for export -Packing in California-German agitation-Wrapping the fruits-Snugness in packing-Trade-marks-Fruit must be well grown.-Packages . . . . . • . .

Packing houses and appliances. Two types of houses - Packing tables-Sorting tables-Apple presses . . $425-434$

Storing Fruts, General advice-Storage is a business by itself-Temporary storage-Risks in storing-Coöperative storage.-Requisites for domestic storage-Ventilation -Moisture-Fruit trays. - Storage Buildings-Various types -Vermont apple house-Alwood's house-Alcoholic vapor as a fruit preservative. . . . . . . . . 435-461

ShIPPING AND REACHING THE CONSUMER. The grower and the consumer-How to reach the market.-Refrigerator cars-Shipping associations-An illustration of a fruit market. . . . . . . . . . . .461-479

\section{APPENDIX (pages 481-500)}

I. How did the varieties of FRUits oRiginate? 481-482

II. Remarks on classifying and Describing Fruits 483-487 III. AMERICAN BOOKS ON FRUIT-GROWING. . . 488-501 

$+$ 


\section{THE PRINCIPLES OF FRUIT- GROWING.}

\section{CHAPTER I.}

\section{INTRODECTORY DISCUSSION.}

FRUIT-GROWING and pomology are synonymous terms. They comprise the whole art of raising fruits and fruit-trees, and the applications of the various sciences thereto. It is impossible to define what a fruit is, in the sense in which the term is universally understood in pomological writings. It is best delimited by giving a list of those products which are commonly known as fruits. If a definition were attempted of the use of the word in its pomological application, it would be approximately correct to say that a fruit is the edible product of a woody or a tree-like plant, - as of a tree, bush, or vine,- and which is intimately associated in its development with the flower. This conception of a fruit is wholly unlike the botanical idea, for the botanist defines the fruit to be the ripened pericarp and attachments. It should be said, however, that this confusion in terminology is not the fault of 
the horticulturist, for the botanists have taken this common-language word and have given it a technical meaning. The word belongs primarily to gencral literature and horticulture, and if the botanist desires to impress it into other service, he must be prepared to accept the confusion which arises.

\section{INVENTORY OF FRUITS.}

Pomological fruits may be ronghly classified under four heads, - tree fruits, vine fruits, small fruits, and herb-like fruits. The following is an inventory of the staple fruits of the United States and Canada, and of those lesser known speeies whieh, having been tried in this territory, either give promise of sueessful cultivation here or have been more or less prominent subjects of discussion:

\section{Class I. Orchard* Culture, or Tree-fruit Culture.}

Seb-class 1. Pomaceous fruits.

Apple, Pyrus Mfulus.

Crab apple, Pyrus baceata.

Prairie erab, Pyrus Ioensis.

Atlantic crab, Pyrus coronaria.

Pear, Pyrus communis.

Sand pear, Pyrus Sinensis.

Quince, Pyrus Cydonia.

Chinese quince, Pyrus Cathayensis.

Japan quince, Pyrus Japonica.

Maule's quince, Pyrus Maulei.

Medlar, Mespilus Germanica.

Loquat, Eriobotrya Japonica.

* Orchard (originally herb-yard, and now rarely written hortyard). An assemblage or plantation of fruit trees. 
SUB-CLASS 2. Drupaceous or stone fruits.

Plum, Prunus domestica.

Myrobalan plum, Prunus cerasifera.

Japan plum, Prunus triflora.

American plum, Prunus Americana.

Wild Goose plum, Prunus hortulana.

Chickasaw plum, Prunus angustifolia.

Sand plum, Prunus Watsoni.

Beach plum, Prunus maritima.

Pacific plum, Prunus subcordata.

Apricot plum, Prunus Simonii.

Sweet cherry, Prunus Avium.

Sour cherry, Prunus Cerasus.

Sand cherry, Prunus Besseyi.

Peach and nectarine, Prunus Persica.

Apricot, Prunus Armeniaca.

Japan apricot, Prunus Mume.

Purple apricot, Prunus dasycarpa.

Sub-class 3. Citrous fruits.

Orange, Citrus Aurantium.

Tangierine orange, Citrus nobilis.

Citron, Citrus Medica.

Lemon, Citrus Medica var. Limon.

Lime, Citrus Medica var. Limetta.

Sour lime (lime of the U. S.), Citrus Medica var. acris.

Grape-fruit, Shaddock or Pomelo, Citrus Decumana.

Kumquat, Citrus Japonica.

Trifoliate orange, Elgle (or Citrus) trifoliata.

Glycosmis, Glycosmis aurantiaca.

Lime berry, Triphrasia trifoliata.

White sapota, Casimiroa edulis.

Sub-class 4. Moraceous fruits.

Fig, Ficus Carica.

White (and Russian) mulberry, Morus alba.

Black mulberry, Morus nigra.

Red mulberry, Morus rubra.

Downing mulberry, Morus multicaulis.

Japan mulberry, Morus Japonica.

Bread-fruit, Artocarpus incisa. 
Sub-class 5. Anonaceous fruits.

Sour-sop, Anona muricata.

Sugar-apple, Anona squumosa.

Cherimoya, Anonu Cherimolia.

Pond-apple, Anona laurifolia.

And other anonas.

Northern Papaw, Asimina triloba.

SCb-Class 6. Myrtaceous fruits.

Guava, Psillium Guajara, and others.

Rose-apple, Eugenia $J_{\text {atmbos. }}$

Surinam cherry, Eugenia uniflort.

And other eugenias.

Stb-class 7. Sapotaceous fruits.

Sapodilla, dehras Sapota.

Marmalade tree, Lucuma mammosa.

Star-apple, Chrysophyllum Cainito.

And others.

Sub-class 8. Anacardiaceous fruits.

Mango, Mangifera Iulica.

Jew plum, spondias dulcis.

Sub-class 9. Ebenaceous fruits.

Kaki (Japan persimmon), Diospyros Kaki.

Persimmon, Diospyros Virginiana.

Sub-class 10. Leguminous fruits.

Tamarind, Tamarindus Indica.

St. John's Bread, or Carob, Ceratonia siliqua.

Sub-class 11. Nut-fruits (Nuciculture).

Walnut, Juglans regia.

Japan walnut, Juglans Sieboldiana.

Black walnut, Juglans nigra.

Butternut, Juglans cinerea.

Pecan, Hicoria Pecan.

Shell-bark hickory, Hicoria ovata and H. laciniosa. 


\section{The Orchard and Vine Fruits.}

European chestnut, Castanea vesca.

American chestnut, Castanea Americana.

Japan chestnut, Castanea Japonica.

Chinquapin, Castanea pumila.

Filbert, Corylus Avellana.

Litchi, Nephelium Litchi.

Ginkgo, Ginkgo biloba.

Almond, Prunus Amygdalus.

Russian almond, Prunus nana.

Tropical almond, Terminalia Catappa.

Cashew, Anacardium occidentale.

Pistacio, Pistacio vera.

Sub-class 12. Palmaceous fruits.

Cocoa-nut, Cocos nucifera.

Date, Phonix dactylifera.

And others.

Sub-Class 13. Miscellaneous tree-fruits.

Olive, Olea Europaa.

Pomegranate, Punica Granatum.

Papaw, Carica Papaya.

Hovenia, Hovenia dulcis.

Jujube, Zizyphus Jujuba, and others.

Myrica, Myrica Nagi (M, rubra).

Sea-grape, Coccoloba uvifera.

Otaheite gooseberry, Phyllanthus disticha.

Spanish lime, Melicocca bijuga.

Alligator pear, Persea gratissima.

Strawberry tree, Arbutus Unedo.

Mammee apple, Mammea Americana.

\section{Class II. Vine-fruit Culture.}

Sub-Class 1. Viticulture; comprising

Wine grape, Vitis vinifera.

Fox grape, Vitis Labrusca.

Summer grape, Vitis astivalis,

Post-oak grape, Vitis astivalis, var. Linsecomii.

Muscadine and Scuppernong grapes, Vitis rotundifolia. 
Sand grape, Vitis rupestris.

River-bank grape, Vitis vulpina.

And other native species of vitis.

Scb-class 2. Passifloraceous fruits.

Granadilla, Passiflora edulis.

And others.

\section{Class III. SMall-fruit* Culture.}

Sub-class 1. Bush-fruits.

Group $a$. Rubaceous fruits (cane-fruits, or bramble-fruits).

Raspberry, Rubus Ideus.

Black-cap raspberry, Rubus occidentalis.

Red raspberry, Rubus strigosus.

Wineberry, Rubus phanicolasius.

Blackberry, Rubus villosus.

Northern dewberry, Rubus Canadensis.

Southern dewlerry, Rubus trivialis.

Paeific dewberry, Rubus vitifolius.

Group $b$. Ribaceous fruits.

Currant, Ribes rubrum.

Black currant, Ribes nigrum.

Buffalo currant, Ribes arereum.

Gooseberry, Ribes Grossularia.

American gooseberry, Ribes oxyacanthoides.

Group $c$. Miscellaneous bush-fruits.

Juneberry, Amelanchier oblongifolia.

Buffalo berry, shepherdiu argentea.

Goumi, Elevagnus multiflora (E'. longipes).

Caraunda, Carissa Carundas.

* small-fruits. A term applied to all small and berry-like fruits which are produced upon bushes or perennial herbaceous plants; as eurrant, blackberry, rasplerry, strawberry. In Europe the strawberry is classed with garden vegetables. Small-fruits is an Americau term.

Bush-fruits. Fruits which are borne upon bushes, or small woody plants destitute of a central stem or axis. 1t is an English term, and is equivalent to small-fruits, except that it does not include the strawberry. 


$$
\text { Non-woody Fruits. }
$$

SuB-Class 2. Strawberry culture.

Garden strawberry, Fragaria Chiloensis.

Hautbois strawberry, Fragaria moschata.

Alpine strawberry, Fragaria vesca.

Virginian strawberry, Fragaria Virginiana.

Sub-class 3. Cranberry eulture.

Common cranberry, Vaccinium macrocarpon.

CLASS IV. NoN-woody or Herb-like Fruits.

Sub-Class 1. Musaceous fruits.

Banana, Musa Sapientium.

Plantain, Musa paradisiuca.

Sub-class 2. Pineapple.

Common pineapple, Ananas sativus.

Sub-class 3. Cactaceous fruits.

Prickly pear, Opuntia Tuna, and others.

Indian fig, Opuntia Ficus-Indica.

Barbadoes gooseberry, Pereskia aculeata.

Sub-Class 4. Miscellaneous herb-like fruits.

Cyphomandra, Cyphomandra betacea.

Ceriman, Monstera deliciosa.

THE GEOGRAPHY OF FRUIT-GROWING.

Fruit-growing, in common with all agricultural pursuits, thrives best in certain geographical areas. That is, the business is not capable of equal development in all parts of the country. The leading determinative factor in the distribution of fruit-culture is climate. The particular quality or factor of elimate which determines the fruit-zones differs with each 
type or group of fruits; but in general it may be said that the relative annual temperature is the most influential factor.

The temperature determinant. - It is eustomary to recognize three general elimatal fruit-zones,-the temperate (typified by the apple and the peach), the semi-tropieal (citrous tribes, fig, olive, pomegranate), and the tropical (cocoa-nut, banana, anona, mango). There are no positive limits of temperature which mark off or separate these zones; but it is enough for our purpose to say that the temperate zone is one which is marked by a long winter of freezing and by the deciduons types of fruits; the semitropical zone is one in which the winter is a short season of light frosts or only oecasional freezes, and in which the fruit trees are evergreen or very nearly so ; and the tropieal zone is frostless, and is marked by evergreen and mostly ever-growing fruit-plants.

The limits of these elimatal zones are exceedingly devious. In eastern North Ameriea, the northern limit of profitable fruit-growing is not far from the forty-fifth parallel, and the limit sinks considerably lower than this in the middle west, and rises much above it on the Paeific slope. The northern limit of the sub-tropieal zone in the east is Northern Florida and a narrow area skirting the Gulf of Mexico, and upon the western side of the continent it extends in the valley elimates as high as the fortieth parallel. The only portion of the tropical fruit-zone which lies in the United States is in extreme southern Florida, comprising about two 
degrees of latitude (reaching northwards to about $\left.27^{\circ}\right)$. Beyond all these bounds there are special localities in which fruits of the adjacent zone may thrive for a series of years, and the fruits of contiguous zones overpass. The strawberry is probably the most tractable of all our fruits as respects climates, because its stature and habit allow it to be protected from extreme cold and its short period of growth allows it to thrive in the cool season of the warmest sub-tropical regions.

The annual temperature of a region is chiefly determined by three factors, - the latitude, the altitude, and the proximity or remoteness of large bodies of water.

The moisture determinant.-The second chief factor of climate in determining the fruit-zones is relative humidity. Whilst the isotherms - or lines of equal temperatures - run easterly and westerly, the isohyetals-or lines of equal rainfall-have no intrinsic direction. They are determined by physiographical characters. In the United States, there are three general fruit-zones which are marked by peeuliarities of rainfall. These are the Atlantic zone, a moist area which is bounded westward approximately by the Mississippi River; the plain zone, extending westward to the mountains; and the Pacific slope zone. The two latter are relatively dry.* The interior or plains region is particularly

* We should, perhaps, make a fourth division, to comprise the arid or Sonoran zone of New Mexico and Arizona, bnt this area is yet too little known in a pomological way to demand specific treatment here. 
trying to fruits because of the strong and dry winter winds, which evaporate the moisture from the trees whilst the ground is often so deeply frozen that the roots cannot supply moisture. There is probably always evaporation from tree tops in winter when the air is drier than the wood.

The fact that moisture may be lost from winter twigs is a most important consideration in the study of the winter injury of trees, and it throws light upon the severe damage which often follows the "dry freezing" of nursery trees in transit and of fall-planted trees. A few figures will show the extent to which evaporation may take place through the bark of dormant twigs.*

The extent to which loss of moisture may take place through the bark of dormant twigs may be determined by eutting off the twigs and quickly sealing over the ends with wax, weighing them, and then detecting the loss in weight from time to time. The following figures of such measurements will serve to emphasize the fact that moisture is lost from winter twigs, althongh they are not designed to show the actual rate of this loss when the twigs occupy their natural position on the tree.

April 7, a cion of apple weighing 4.425 grams was placed on a balance, and the loss by evaporation measured at intervals during three days. The cut end of the cion was sealed with wax to confine evaporation to that which may take place through the bark. The balance or scales was placed

* Bailey, Cornell Exp. Sta., Bull. 117, pp. 385-388. Work done in Michigan. 
in a living-room, where the readings could be taken at frequent intervals. It will be noticed that the rate of evaporation was nearly constant, averaging about one-half a centigram per hour:

\begin{tabular}{|c|c|c|c|c|c|c|c|c|c|c|c|c|c|c|c|}
\hline & $\begin{array}{l}\text { Lost } \\
\text { in } \\
2 \text { hrs }\end{array}$ & $\begin{array}{l}\text { Addi- } \\
\text { tional } \\
\text { loss } \\
\text { in I2 } \\
\text { hrs }\end{array}$ & $\begin{array}{c}\text { In } \\
\text { 18 } \\
\text { hrs }\end{array}$ & $\begin{array}{l}\text { In } \\
24 \\
\text { hrs }\end{array}$ & $\begin{array}{l}\text { In } \\
26 \\
\text { hrs }\end{array}$ & $\begin{array}{l}\text { In } \\
36 \\
\text { hrs }\end{array}$ & $\begin{array}{l}\text { In } \\
44 \\
\text { hrs }\end{array}$ & $\begin{array}{l}\text { In } \\
48 \\
\text { hrs }\end{array}$ & $\begin{array}{l}\text { In } \\
51 \\
\text { hrs }\end{array}$ & $\begin{array}{l}\text { In } \\
60 \\
\text { hrs }\end{array}$ & $\begin{array}{l}\text { In } \\
64 \\
\text { hrs }\end{array}$ & $\begin{array}{c}\text { In } \\
68 \\
\text { hrs }\end{array}$ & $\begin{array}{l}\text { In } \\
77 \\
\text { hrs }\end{array}$ & $\begin{array}{c}\text { To- } \\
\text { tal } \\
\text { loss }\end{array}$ & $\begin{array}{l}\text { Per } \\
\text { cent } \\
\text { loss }\end{array}$ \\
\hline $\begin{array}{l}\text { weighing } \\
4.425 \\
\text { grams. }\end{array}$ & $\begin{array}{c}1 \\
\mathrm{eg} .\end{array}$ & $5 \mathrm{cg}$. & $\begin{array}{c}2 \\
\mathrm{cg} .\end{array}$ & $\begin{array}{c}5 \\
\mathrm{cg} .\end{array}$ & $\begin{array}{c}2 \\
\mathrm{cg} .\end{array}$ & $\begin{array}{c}5 \\
\mathrm{cg} .\end{array}$ & $\begin{array}{c}4 \\
\mathrm{eg} .\end{array}$ & $\begin{array}{c}2 \\
\mathrm{eg} .\end{array}$ & $\begin{array}{c}2 \\
\mathrm{cg} .\end{array}$ & $\begin{array}{c}4 \\
\mathrm{cg} .\end{array}$ & $\begin{array}{c}2 \\
\mathrm{cg} .\end{array}$ & $\begin{array}{c}2 \\
\mathrm{eg} .\end{array}$ & $\begin{array}{c}3 \\
\mathrm{eg} .\end{array}$ & $\begin{array}{l}39 \\
\text { cg. }\end{array}$ & 8. \\
\hline
\end{tabular}

It has been said that the rate of the loss of moisture from trees in winter determines the relative hardiness of different varieties of apples, and of some other fruits; and similar inferences have been made respecting the ability of foliage to endure summer droughts. The following table shows studies of twigs of varieties of different degrees of hardiness, but it will be seen that the per cent of loss of moisture bears no relation to the supposed hardiness of the varieties.

Early in April, twigs from the previous year's growth were taken from several varieties of apples, which vary much in their ability to endure our climate (those marked by asterisks being supposed to be the hardiest varieties). The twigs were carefully weighed, and the cut ends were then sealed with wax to prevent evaporation only through the bark. At the expiration of two days the wax was removed and the twigs were again weighed. The twigs were kept in an open shed: 


\begin{tabular}{|c|c|c|c|c|}
\hline Varieties. & $\begin{array}{l}\text { Original } \\
\text { weight. } \\
\text { Grams. }\end{array}$ & $\begin{array}{c}\text { Weight at } \\
\text { the expira- } \\
\text { tion of two } \\
\text { days. } \\
\text { Grams. }\end{array}$ & Loss. & $\begin{array}{l}\text { Per cent } \\
\text { of loss. }\end{array}$ \\
\hline 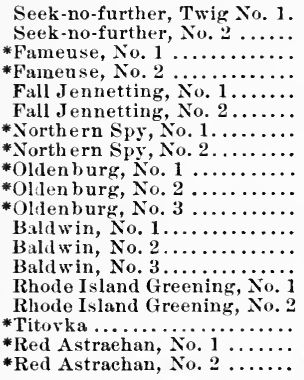 & $\begin{array}{l}1.07 \\
1.3275 \\
1.095 \\
.82 \\
1.0475 \\
1.45 \\
1.38 \\
1.155 \\
1.595 \\
1.8475 \\
1.3725 \\
2.11 \\
1.34 \\
.93 \\
1.1825 \\
1.055 \\
1.8075 \\
1.45 \\
1.4825\end{array}$ & $\begin{array}{l}.985 \\
1.255 \\
1.025 \\
.725 \\
1 . \\
1.3875 \\
1.3125 \\
1.0925 \\
1.55 \\
1.7475 \\
1.265 \\
2.0025 \\
1.26 \\
.87 \\
1.11 \\
.99 \\
1.7075 \\
1.3425 \\
1.4075\end{array}$ & $\begin{array}{l}.085 \\
.0725 \\
.07 \\
.085 \\
.0475 \\
.0625 \\
.0675 \\
.0625 \\
.045 \\
.1 \\
.1075 \\
.1075 \\
.08 \\
.06 \\
.0725 \\
.065 \\
.1 \\
.1075 \\
.075\end{array}$ & $\begin{array}{c}7.94 \\
5.46 \\
6.39 \\
10.3 \\
4.53 \\
4.31 \\
4.89 \\
5.4 \\
2.8 \\
5.3 \\
7.8 \\
5.09 \\
5.9 \\
6.4 \\
6.1 \\
6.1 \\
5.5 \\
7.4 \\
5.1\end{array}$ \\
\hline
\end{tabular}

The following table shows that there is great variation in the rate of water loss between twigs of the same variety of apple:

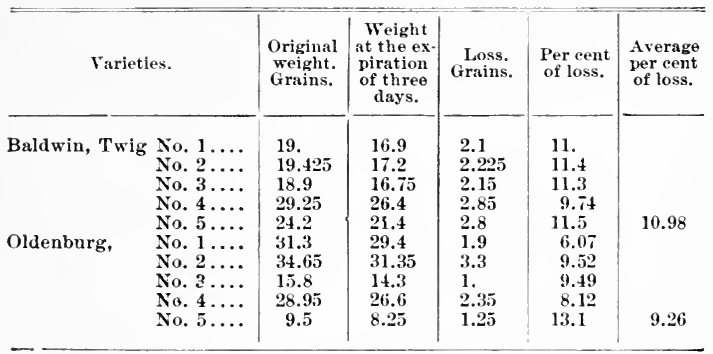


This subject of moisture loss from dormant trees seems to be a most important one, and it is strange that the matter seems to have escaped the attention of pomologists. In order to spread a knowledge of the subject, further studies in the evaporation from winter twigs have been made for me by my student, A. L. Knisely, M.S.:

"In January, 1897, I ent twigs of various kinds about one foot in length, and took them to the laboratory. When ready to weigh the twigs, they were cut down to about four or five inches in length, the object of the second cutting being to leave as little time as possible between the eutting of the twigs and the weighing. As soon as the short twigs were cut, they were weighed, and the freshly cut ends were then dipped in melted paraffine, thus sealing the cut surfaces and preventing evaporation except through the bark and buds of the twigs. After dipping in the paraffine, they were weighed again, and then put in places as much exposed as were the trees from which they eame; in fact, in some cases, the twigs were tied on the trees and left there for 72 hours, and then weighed. They were afterward exposed for another 72 hours and weighed again, making a total length of time of 144 hours, or 6 days, that the twigs were exposed. During all this period, the thermometer registered below the freezing point. That there is loss of moisture by evaporation is shown by the following table, which gives the data obtained from the twigs of a number of our most common fruit and shade trees: 


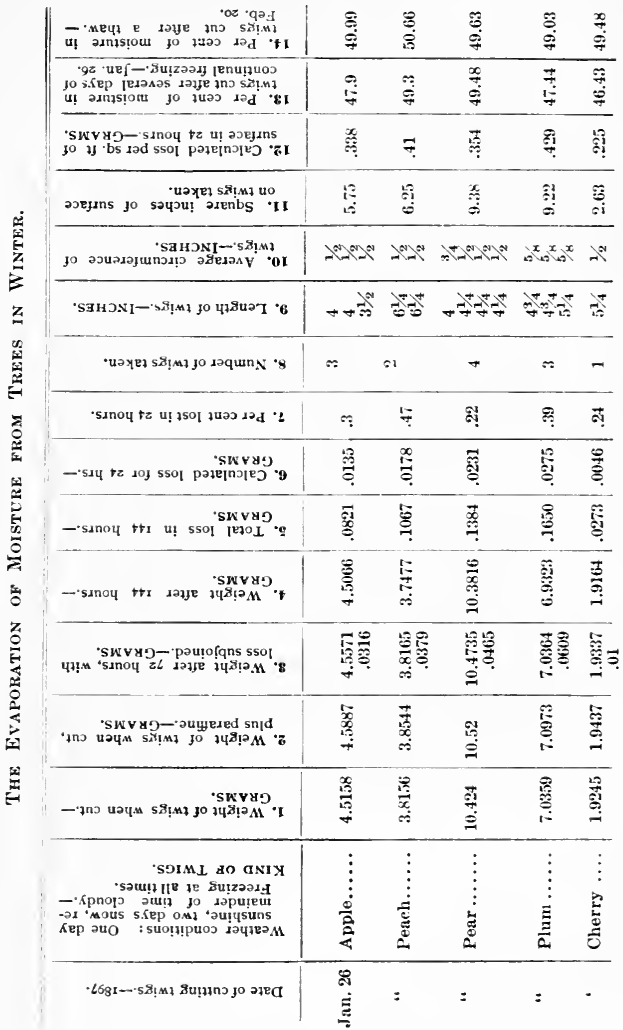




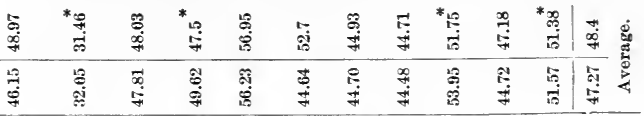

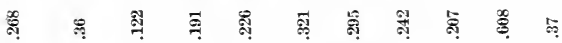

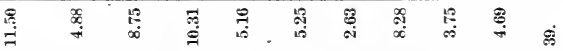

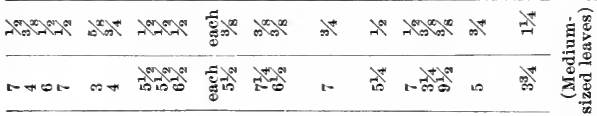

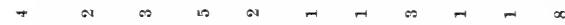

ซุ.

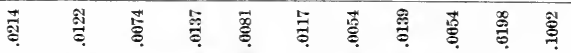

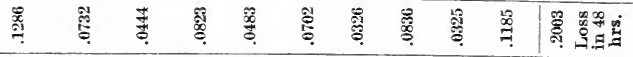

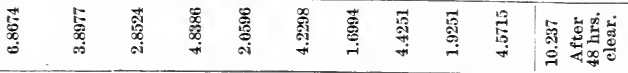

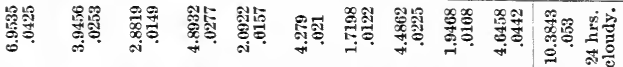

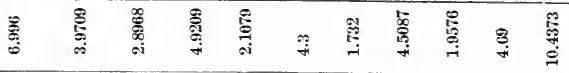

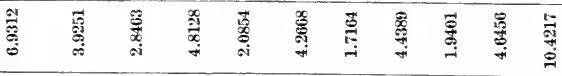

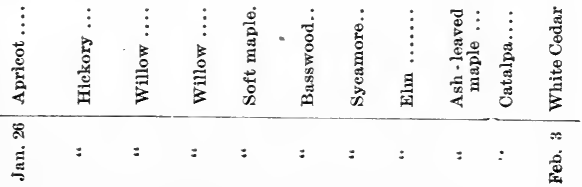


"In observing trees in continuons severe winter weather, $m y$ attention has often been called to the fact that the twigs seem somewhat duller and more somber than usual, and in some cases tend to shrivel up and have the appearance of drying out. When a warm spell comes, this condition changes, and the twigs become brighter and seem to freshen up, and sometimes I imagine that they become more plump. The freshening-up feature is especially noticeable on large clumps or groves of willow; the twigs usually take on a much brighter eolor during warm spells in winter than during the continued freezing weather. During thawing weather, the equilibrium is maintained between the noisture or sap in the tree top and that taken in by the roots, and as fast as moisture evaporates from the tree top, sap flows up from the roots and the equilibrium is re-established. In freezing weather, the moisture, even though frozen, is probably evaporating from the tree tops; and the sap, being frozen, does not flow up from the roots and replace the evaporated moisture. Thus the equilibrium between the tree tops and roots is unbalanced, and it is at this time that the twigs become shriveled by reason of moisture being lost and not replaced.

"In support of these statements, I made the following investigation: After several days of continnous freezing weather, and at a time when I expeeted a thaw, I cut twigs of a variety of trees and estimated the percentage of moisture contained in them. Again, just as soon as a thaw eame, I cut 
twigs from the same trees and from the same parts of the trees, and estimated the percentage of moisture again, the object being to determine if the twigs contained less moisture after several days of continued freezing than they did a short time later, during a thaw. The last two columns of figures in the table (pages 14 and 15) are upon this subject. The average water content of those twigs cut during a freeze was 47.27 per cent, while that of those cut later, during a thaw, was 48.40 per cent, being an increase of 1.13 per cent, even though the trees had been constantly losing moisture by evaporation. Therefore I conclude that during every thaw in winter, the tree top fills with sap, and then if a sudden severe freeze comes, we are likely to have injured trees, due, no doubt, to the sudden freezing of the sap, and to the loss of moisture when none can be supplied.

"It will be interesting to calculate what weight of moisture a tree may lose in winter. A certain soft maple, standing 30 to 35 feet high, with a trunk of 15 to 18 inches in diameter near the ground, exposes from 750 to 800 square feet of surface, and loses daily by evaporation from 170 to 180 grams of moisture. A given elm tree, 12 to 15 inches in diameter at the base, possesses some 300 to 400 square feet of surface, and loses daily from 70 to 100 grams of moisture. An apple tree 30 years old, with a trunk 15 inches in diameter, with a dense, bushy top, possesses approximately from 800 to 1,000 square feet of surface, and loses daily from 275 to 
350 grams of moisture." These ealculations, therefore, may explain some of the injuries which follow very dry winters.

Since evaporation takes place through the bark of winter twigs, it is reasonable to suppose that the tenderness of some trees in dry winter climates (as in our plains regions) may be due to such an anatomical structure of the bark as does not resist evaporation, and that, on the other hand, hardiness may sometimes be a matter of thickness or denseness of bark. Studies in this direction have been made at Cornell, and they indicate that this supposition may be well founded in certain eases, but the investigations are not yet sufficiently extended to allow of any definite statements.

The soil determinant.-There are special adaptations of fruits to soils. Pomologists are well aware of this fact as a general truth, but very little close attention has been given, in this country, to the minor applications of it. To be explieit, it is well understood that pears flourish best on elay soils and peaches best on sandy soils, but there are, no donbt, distinet preferences amongst the varieties of pears and peaches themselves. It is possible, in fact, that each distinct family or type of varieties of any species has preferences of land and location, and it will be the business of coming generations to determine what these peenliarities are. With the increasing refinements and competitions of the future, the special and local problems must receive more and more attention. If these positions are well taken, it 
must follow that the promiscuous and wholesale dissemination of a few varieties over the country must eventually cease, and that local and special sorts must constantly tend to drive out the cosmopolitan and general varieties. In this country, it is only in the strawberry that the peculiarities of adaptation of varieties to soils have begun to be well understood; and this is rather because the subject is forced upon the attention by the short generations and constantly shifting plantations of the plant than from any investigational motive.

Many of our fruits are very cosmopolitan as to soils, although there are, probably, none of them which are indifferent to even comparatively minor variations in land. Of the temperate fruits, the apple undoubtedly has the most generalized adaptabilities to soils, and this is closely seconded by the domestic plum. Amongst semi-tropical fruits, the orange thrives upon a wide range of soils. The peach and grape are more exacting, and the same may be said of the pineapple amongst semi-tropical fruits.

Now and then fruits are made to grow in soils which are uncongenial to them by working them upon adaptive stocks. Thus the plum may thrive in sandy regions when it is budded upon the peach, the pear is sometimes grown upon very light lands by working it upon the mountain ash, and the mahaleb cherry is thought by most persons to be a better stock for strong soils than for light ones. We may look for the time when certain varieties of the same species may be selected as stocks for 
given soils. But all this forced adaptation to soils is a very special matter, and it only illustrates the more strongly the great importance of giving particular attention to the general subject of the adaptabilities of species, varieties, and even of strains, to variations in soils.

The parasite determinant.-Inasmuch as many of the organisms which seriously interfere with fruitgrowing are more or less restricted in their range, it would seem to follow that the zones of profitable fruit-culture may be determined more or less by the parasite factor. A moment's reflection will show, however, that the geographical distribution of the parasite is determined primarily by climate and by the distribution of its host-plants; so that, on the one hand, the climatal limit of the cultivation of the fruit may be approximately the climatal distribution of the pest, and, on the other hand, the parasite is local or cosmopolitan according as the fruit is either local or widely grown.

Many of the common pests are restricted in range because they have not ret reached the full limit of their distribution. An excellent illustration of this fact occurs in the case of the codlin-moth. A generation ago, Michigan was represented to be the Eutopia of the apple-grower because of the absence of this pest, and in our own day similar recommendations have been made of Oregon and other far western states. To the naturalist, however, it was evident from the first that the insect was following closely behind the apple frontier, as a storm follows 
an area of high pressure. It is evident, too, that no amount of legislative enactment could have stayed the dispersion unless it should have forbidden the planting of apple trees.

As a matter of practice, the energetic and intelligent fruit-grower will think last and least of the parasite factor when locating his plantation, for this factor is variable and migratory, and, moreover, there are means of keeping most fruit pests under control. Insects and fungi are apt to be bugbearssometimes literal bugbears-to the fruit-grower; but, after all, they are rarely to be counted upon as permanent factors, and they are the direct and perhaps the most efficient means of keeping the farmer in a state of mental alertness. There are a few cases, of course, to which these remarks will not well apply, but they are clearly exceptions. One of these is the dreaded nematode root-knot. of the southern states, and one might seriously hesitate in planting peaches where the ground does not freeze deep enough to destroy the pest. The professional experimenters can determine the course of the lifehistories of the various pests, and can point out their most vulnerable points, and may even devise general means for their eradication; but the final application of this knowledge is a local problem, which each man must work out for himself. Laws are generally of little avail for the destruction of pests, except in those few cases in which disease is more or less permanent or perennial, and in which there is no practicable recourse but to destroy the 
plant or the part affected. Such troubles are peach yellows, and black-knot of the plum and cherry. A law cannot be enforced unless public sentiment is behind it, and when public sentiment is aroused the law is not needed. Yet a law is often useful for a time to awaken public sentiment and to eall attention to the evil. The final recourse is always greater knowledge and enlightenment.

There are also insurmountable difficulties in the enforcement of laws designed to control the spread of noxious insects and fungi, because it is practically impossible to detect the eggs of inseets or spores of fungi upon a large number of plants, and beeause there are so many natural and uneontrollable ways in which the parasites may spread. The original Maryland law, designed to prevent the introduction of fruit-tree diseases and pests, was a case in point. It required that "whenever any trees, plants or vines are shipped into this state from another state, every package thereof shall be plainly labeled on the outside with the name of the consignor, and a certifieate showing that the contents had been inspected by a State or Govermment officer, and that the trees, plants or vines therein eontained are free from all San José scale, yellows, rosette and other injurious insect or disease." It would be impossible for any botanist to certify that a dormant tree were free of all disease; and even in the matter of San José scale, an entomologist could not give a clean bill of health without giving more time to the examination of a tree than it is worth. In the operating of 
this law, trees were allowed to pass if an officer certified that he had examined them and had found no evidence of disease thereon, which is a very different matter from asserting that they are free from dis. ease, and which is a virtual acknowledgment that such provisions of laws really cannot be enforced. The best laws of this nature, and for the regulation of spraying and the like, are probably those which are not mandatory, but which provide a protection or a legal remedy in case any person considers himself to be endangered or injured by the perverseness or the negligence of another; and it is a question if the common law does not provide ample redress for such grievances. There are instances, too, in which it may be wise to make a general effort to stamp out a pest when it first obtains a foothold in America, but this is a very different matter from the endeavor to control the spread of insects and fungi between the different parts of the country. The fact is, that most insects and diseases are beyond the reach of legislative fiats, and it is time that the fact were fully learned. The demand for functionary proceedings against the bugs sometimes recalls the laborious efforts of the Middle Ages. "At one time," writes Fernald,* "a thoroughgoing procedure, according to all the rules of jurisprudence, occurred before the spiritual judge. The accused insects were summoned, and in ease of non-appearance, which always occurred, unless the insects were moving to new feed-

*C. H. Fernald, "The Evolution of Eeonomie Entomology," Proe. Eighth Annual Meeting Assoe. Econ. Entomologists, 1896. 
ing grounds and the court-house happened to be in their way, a proxy was appointed to represent the accused insects, who debated the whole subject with the accuser, after which judgment was rendered, invariably against the accused insects in the form of an excommunication, which was carried into effect only when the insects disappeared at the time of pupation."

The suggestion which Washington is said to have made upon the constitution whilst that instrument was under discussion, is not inapplicable to the present subject. A clause having been proposed that the standing army should be limited to five thousand men, he suggested that another clause be inserted forbidding any foreign power to invade us with more than three thousand men!

It is probably advisable to provide for inspeetion of plants at ports of entry, but too much should not be expected of such examinations. The examination soon comes to be largely a perfunctory matter, and the most serious pests may easily slip through the hands of officers. It is probable that no law could be devised which could have kept the codlin-moth, Hessian-fly, gipsy-moth, and a seore of other pests, out of the country, to say nothing of the fungous diseases, which are more difficult to detect. Then, again, one can never tell what insects are likely to become troublesome upon introduction into a new country. Many insects which are comparatively innocnous in their native country, and against which, therefore, no suspicion exists, may become scourges in an- 
other country. A comparatively harmless insect in France becomes the dreaded horn-fly in America. Again, the demand for legislation usually arises because of the incursion of some new intruder, but a pést is commonly worst when newly introduced, for, like a prairie fire, it finds its course unimpeded. After a time it reaches an approximate limit to its furious spread, parasites overtake it, and other pests contest its feeding grounds. Nearly all insect pests lose Tmuch of their terrors after they have once ruu over the country. This is admirably illustrated in the potato-bug.* In other words, the first appearance of a pest in formidable numbers is apt to result in a scare, to which, it is to be hoped, the San José scale, which is now attracting so much attention in the east, is no exception. The fact is, that insect and fungous pests are inevitable, and the farmer ean have no peace of mind until he accepts the fact, and then resolutely prepares to meet them, both by strategy and direct battle. Yet, if now and then a serious pest can be kept out of the country, even for a few years, by means of inspection upon the frontiers, the effort may be eminently worth the while.

\footnotetext{
* It may as well be said, once for all, that the writer uses the word bug for any hard-shelled insect. The entomologist uses it technically for a certain classificatory group of inseets, and be generally insists that everyone else use it in the same way; but it should be remembered that the word was a common-language term long before the entomologist impressed it into special use. This common usage, therefore, has prior rights; and since it is impossible to make people use it in the entomological sense, it is plain that the entomologist must be prepared to accept any confusion which arises from his use of it. He can probably arrive at his purpose quicker and better by using purely technical terms.
} 
THE COLRSE OF EVOLU'TION OF A FRUIT REGION.

Fruit-growing is nsually a comparatively late development in any region. The epochs which precede the agricultural occupation of a country are commonly about as follows: Discovery, exploration, hunting, speculation, lumbering or mining. The real and permanent prosperity of a country begins when the agriculture has evolved so far as to be self-sustaining and to leave the soil in constantly better condition for the growing of plants. Lumbering and mining are simply means of utilizing a reserve which nature has laid by, and these industries are, therefore, self-limited, and are constantly moving on into unrobbed territory. Agriculture, when at its best, remains forever in the same place, and gains in rirhes with the years; but in this country it has so far been mostly a species of mining for plant-food, and then a rushing on for virgin lands.

The first effort in an agricultural regiom is generally the growing of the staple crops, like the grains or bread-stuffs. This is both because the capabilities of the country are all unknown, and becanse such regions are far removed from the markets, and must, therefore, grow such commodities as can be stored or shipped long distances; and it may be said, also, that the growing of these crops in a new country demands comparatively little special skill. The second development is very often a stock-raising or grazing industry. If the country possesses special adaptabilities for fruits, a man here and there will be found en- 
larging his orchards or small-fruit plantations, and in time there is a wide-spread revolt from general farm practices to fruit-growing. The growing of specialties, or perishable products, or those which are essentially luxuries, demands the finer skill, the more enlightened ideals, and the less fluctuating employments of an old or at least of a well-settled country; and it is in such areas, too, that the best special markets are to be found. It has been the general experience that when any area has fully committed itself to the raising of any particular fruit, the business is soon carried too far, and after a time a revulsion and contraction have come. The lesson is that mixed industries are best for any community, and that it is practically impossible to reduce the agriculture of any large region to a dead level of uniformity.

THE OUTLOOK FOR FRUIT-GROWING.

Two sets of factors chiefly control or determine the outlook of the fruit-grower: the personality of the grower, and the prospective conditions of the market. Few people appreciate how personal a thing success is: yet everyone knows that any two persons placed in the same physical and environmental conditions, and given an equal chance, will arrive at very various results in business. The real directive forces are matters of character and personality, of which the most important requisites seem to be love of the occupation, indomitable energy, cool judge- 
ment, and sterling honesty. The man should not set before himself the single standard of moneygetting, when entering upon a rural life. The end of life is happiness, and it may often be secured just as well on a moderate income as on a large one. It is pernicious to represent that the farmer can become rich, as that term is commonly employed. It is one of the blessings which agriculture bestows upon both the individual and the nation, that it makes its devotees happy and comfortable without making them wealthy. Of all the leading occupations in which men engage, perhaps there is less mere scramble for money in agriculture than anywhere else; and for this very reason the farmer must forever remain a stalwart and conservative element in our national structure. Farming upon a modest scale is capable of yielding a competent income; but the larger part of the wealth of the small farmer is of a wholly different kind from that of the tradesnian or manufacturer.

It is indispatable that there is always a demand for the best. There is not enough of the best in any commodity. A man cannot make the best unless he has ability for it. It is more important, therefore, that the first tillage and fertilizing and pruning and spraying should be applied to the man and not to the land nor the erop; and whilst the man is acquiring discipline for the direct prosecution of his business, he is at the same time opening his mind to all the sweetest pleasures of living. On the other hand, there is always a surplus of the 
ordinary. In fact, it is the ordinariness of it which makes it a surplus. Now, inasmuch as most men are ordinary, it follows that most things which they make will be ordinary; and it does not matter if we raise the standard of all men, the greater part will still be ordinary, for we have only raised the ordinariness of the mass. This would seem to argue that the great majority of fruit-growers-to specialize the problem - can never really suceed. This demands that we define what is commonly meant by "the best." That kind of fruit usually sells the best of which there is the least. It may not be intrinsically the best. It is simply that in which there is the least competition. The key-note to the business, therefore, is diversifieation or individuality. The grower should aim to have something or to do something which his neighbors do not do, although it may really not be any better than what they do. We are apt io be discouraged by being told that "there is room at the top," for if we all get to the top then we are all. on the bottom. It is better to say that "there is room at the top and on the sides." The best, as commonly understood, is really the unlike.

If every occupation is already full, then it follows that the choice of an occupation resolves itself into what one cares for and what he has capital for. He need have no fear of his success if he grows what people want, or puts it up so as to make them believe that they want it. In its common levels, fruit-growing, like every other business, is undoubtedly overdone, and there is only a precarious 
living in it. This is most emphatically illustrated in apple-growing-to which the least skilful attention has been given-for the years of crop are years of low prices. This means that apple-growers allow the seasons and other environmental circumstances to absolutely dictate the bearing time of the orchard, and when one man has a erop other men may have one. Yet there is no fruit which comes so near to being a staple commodity as the apple does, and none which has a longer market season, or is capable of manufacture into a greater number of secondary produets.

Perhaps the last thing which the farmer learns, in respect to his own business, is to thoroughly master his local conditions. He must feel that his problems of soil and exposure, his limitations of eapital, and his own tastes, are all unique and personal, and he must then begin to work ont his results in his own way. What he ean learn from books and teachers are principles and truths, he ean pick up suggestions, and he can, above all, acquire an ability to grasp his local problems; but he must solve his problems for himself. This is the secret of that close and singleminded attention to business which makes for the greatest success.

The most profitable stock in trade of the fruitgrower, therefore, as already indicated, is training: and if a good part of this training is in pure business methods, very much will be gained, for there are probably ten men who ean grow a given quality of fruit where there is one who can sell it to advan- 
tage. All this is proved by the fact that very many of our best farmers are men who were not brought up on the farm, or who, at least, soon left it for other business. Good business men nearly always make a success of farming. They come into the business with trained minds, skilled judgment, and espeeially without too much stereotyped knowledge, and, therefore, without prejudice. They are willing to learn, and they quickly assimilate new ideas. It sometimes seems as if the farmers of the future are to eome largely from other oceupations, where men are free from the bonds of tradition.

In other words, there are two distinct lines of effort in farming: one is farming proper, or the growing of crops; and the other is business method, which is a matter of exeeutive management. One difficulty with agrieulture at the present time is the fact that every farmer is his own business manager, and it is probably true that less than one-fourth of the men, taking them as they run, are competent to manage a business. When the boys leave the farm for the eity, they fall under the management of the proprietor of an industry or a business, and after a time all those individuals who show special aptitude for executive business rise to their opportunities, and themselves become managers and proprietors. In the increasing complication and complexities of the future, those farmers who are not good executive business men will be obliged to give their attention solely to those enterprises to which they are best adapted; so that there must gradually come to be a separation be- 
tween the business of growing fruit and the business of handling and marketing it.

It may be stated as a general principle that the commercial outlook is best in those fruits which readily yield themselves to the greatest number of secondary or manufactured products, such as canned or evaporated goods, jellies and sauces, liquors, oils, or other commodities used in the arts. In these fruits the grower is not dependent upon a single outlet for his erop; and it should be said that if there is but a single important outlet for a fruit, that outlet is usually the sale in the fresh state, which is the most precarious disposition which ean be made of perishable produets. This truth is well illustrated in the eastern grape business. The grape is consumed almost wholly as a dessert fruit, the only other emphatic outlet being in wine-making, which is eomparatively unimportant in the east. As a eonsequence, the grower is largely at the merey of the market, and this market may be definitely and easily overstocked. In the ease of apples and peaches, the grower has the alternative of eanning or drying the erop, and he may, therefore, be comparatively independent of the contemporaneous market.

In years of heavy crops the returns from poor fruit are the least, and it often happens that the only good which comes from such yields is the lesson upon the business and the morals of good grading and paeking; yet even this forceful lesson seems either not to reach the major part of fruit-raisers, 
or else it is forgotten before the next year of superfluons yields. The enormous apple erop of 1896 was one of these epochs. W. C. Barry* makes the following remarks upon this crop, quoting at first from an English fruit-receiver: "In the first place, quantities have been far too excessive, and a very large proportion of the fruit has been and is of a class that prevents rather than favors extended consumption. With the knowledge of the exceptionally abundant erop, we should have thought shippers would see the necessity for extra care in selecting the fruit, but instead of this, indiscriminate shipping seems to have been practiced largely, while the heavy percentage of faulty conditioned barrels indicates that the packing has also been defective.' In this way, at home and abroad, the crop was practically lost. The outlook is certainly discouraging, but if we are willing to profit by the experience of the year and learn a lesson, it will be of advantage to us. It must be self-evident that hereafter greater care must be exercised in packing, and choicer fruit must be selected for both home and foreign markets. It will probably be many years until a similar crop will be produced. In the meantime, growers should provide themselves with storage houses, where the fruit ean be kept till the time arrives to market it advantageously. * * * As the years pass and our experience increases, it becomes evident that a greater variety of products is necessary to success. The fruit-grower should en-

* President's Address to Western New York Horticultural Soc., Jan. 27, 1897. 
large his sphere of work, and cultivate fruits for the varions seasons of the year, thus giving employment to a regular force of hands, who, on account of their proficiency, become indispensable on a fruit farm. Crops should be anticipated, and markets provided just as the manufacturer seeks and secures sale for his goods."

Is there over-production of fruit?-All these remarks bring up the old question as to whether there is an over-production of fruit. The probability is that there is not an absolute over-production except in speeial years; that is, that there is not more fruit grown than can be consumed in one way or another. It is very likely, however, that there is frequently a relative over-production, - that there is more fruit grown than can be consumed in the markets which are ordinarily at the disposal of the grower. The difficulty is probably rather more one of nnequal or imperfect distribution than of absolute over-production of the commodity. The tendency of the time is to remedy this defect through more perfect means of dissemination, but it is too much to hope for a perfectly equal distribution of fruits, since the fruit areas are more or less limited in their geographical distribution, whilst the fruit consuming population is distributed far and wide. When there are heavy gluts in some markets and fruit does not pay for the freight, there are very often other places, a few hundred miles away, in which the commodity is scarce. The recent introduction of special fruit and refrigerator ears has 
lessened the difficulties of distribution. But the reader should be reminded that these appliances are of use only to organizations, or to those growers who have a large quantity of product; or, at any rate, to those localities in which so much fruit is grown that the community of interests amounts to an organization.

There can be little doubt that fruit must tend to become cheaper rather than higher, except for special kinds and special markets, but the cost of producing it will grow less at the same time. The fruit-grower must acquire the skill to make his plantations bear in the years of least heavy crop, and thereby escape, to a large extent, the effects of over-production. This can certainly be done. The very fact that there are years of over-production and under-production shows that fruit-growers have not yet mastered the conditions which control their plantations. In orchards, at least, there are more persons who discover their crops of fruit than there are who produce them. With the cheapening of the product, the demand will be increased. The United States now leads all countries in the extent, variety, excellence, and abundance of fruits, and our people are pronounced fruit-consumers: and this desire for fruit is very rapidly increasing. In particular fruits, as in grapes in the east, the price seems already to have fallen to the very lowest point of profitable production, and in these cases salvation seems to lie in the hunting out of special markets, in devising more secondary means of disposing of the product (as in 
manufactured goods), and especially in improving the quality of the product and increasing the attractiveness of the packing.

It is a common practice to estimate the amount of fruit which will be produced at any given time in the future by multiplying the number of acres of plantation by the yield of a normal acre of that kind of fruit. The fallacy in these calculations lies in the fact that very many of the orchards which are planted in hope and expectation yield only bugs and fungi. It is probably not too much to say that fully half of the fruit plantations which have been set in the past fail to produce any crop for the market. There are numbers of people who devote their entire energies to copying their neighbors; but having no original grasp of the subject, they are likely to achieve only a haphazard success. 


\section{CHAPTER II.}

THE LOCATION AND ITS CLIMATE.

IT Is apparent that any advice respecting the proper place for engaging in fruit-growing must be of the most general nature, since the species of fruits are so numerous, and the elements which enter into a choice of location and soil are so various and indefinable. Yet there are certain considerations which are approximately fundamental, and to which the reader may profitably give heed. These may be found to be suggestive in improving one's practice upon his established plantation, as well as useful in aiding him in the choice of location and land.

\section{THE PLACE.}

The choice of the place in which to grow fruit, leaving aside the element of soil, ${ }^{*}$ is determined by the location and the site. The location is the position of the place as fixed by the map or the surveyor. It is in such and such a township, and lies along such and such a highway. It is a matter of

* The problems comprised in the selection of the proper soil must be de. termined for each particular fruit. They are, therefore, special questions, and must be treated in the books to be given to the different fruits, and not in a general work npon fruit-growing. 
local geography; it may lie in auy one of a thousand places in the general fruit zones which were outlined in the last chapter. The site is the particular or actual place, in the location or upon the farm, upon which the plantation is set. It comprises the aspect as to whether the exposure is towards the north or the south, and the consideration of the minor elevations and other topographical features of the place. To proceed, then, from the general to the speoific, we may say that a eertain fruit plantation is located at Willow Creek, in New York, and that it has a high site, with a sharp eastward exposure.

In the choice of a location with reference to its geographical position, there are two chief elements to be considered, the choice with reference to market and that with reference to frosts; and to these we may now proceed.

Location with reference to market. - Time has overcome distance. Market facilities are, therefore, determined more by transportation facilities than by nearness to the market itself. To have the choice of two or more means of shipping - as by rail or water, or by more than one railroad - is a most desirable feature in the location of any fruit farm. This is not only because competitive rates may be secured, but also beeause more and various markets may be reached. The choicer the fruits and the greater the desire to reach personal markets, the more should the grower prize any means which shall enable him to reach a number of markets. Such a grower will desire to locate within easy reach of a 
number of cities or large towns. He will not care, perhaps, to grow what may be called the staple varieties, leaving that effort to those persons who are farther removed from points of consumption. It would seem to be unwise, therefore, for the fruitgrower who has access to several or many nnlike markets to attempt to copy the methods of those in the west or south, who must grow largely of one thing and grow that in sufficient quantity to command concessions from transporters and salesmen. Fruit-growing can never be reduced to a dead level of ideals and practice. In one place great specialization may be most profitable, but in another place generalization - the extensive growing of generalpurpose varieties - may be best.

Location with reference to frosts. - In the last chapter, the general influence of cold and heat in determining the fruit zones was discussed. At that place, the subject was the average annual temperature. But within these various zones there are endless minor variations in physiographical features which have a direct influence in determining the areas of the incidental frosts of late spring and early fall. The reader must clearly distinguish between frosts and freezes. Frosts occur on still, clear nights, and are more or less local; freezes are usually accompaniments of storms, often of high winds, and are general or even continental in range, and their courses are not marked by the whiteness of frost. . It was a freeze, and not a frost, which swept over Florida in the winter of $1894-5$, and over the north- 
eastern states in May, $1895 ;{ }^{*}$ and most of the serions disasters of untimely cold are of this kind. These freezes are mostly beyond the reach of man. He can ouly move beyond their limits. But injurious frosts may not only be avoided, in many cases, by the selection of the location or even of the site, but they may sometimes be prevented upon the very night when they are expected.

The chief local determinant of immunity from frost is proximity to bodies of water. These bodies act as equalizers of temperature. The water holds latent heat, and it does not respond quickly to the atmospheric fluctuations. It is, therefore, cooler in summer and warmer in winter than the adjacent land is. The larger and deeper the body of water, the greater is this equalizing effert upon the temperature of the shores. As between the two, great depth is more important than great expanse of surface. Lakes which are only a mile or two wide may exert a very profound influence over the adjacent

* In order to show the natural history of one of these wide-area freezes, the following aceount is given (by E. T. Turner, Neteorologist of the Wenther Bureau of the Department of Agriculture of the State of New York) concerning eauses which led to the disastrons cold suap of May 13, 189., in New York state:

"For about a wcek preceding the 12th, the temperature had been very high, from 80 to 8.5 degrees in the daytime and from 50 to 60 degrees at night. The temperature of the soil must, therefore, have been considerably higher than usual at that time of the year. The conditions which produced the freeze were very general rather than local. About the 9 th, the pressure increaserl and the temperature fell over the western and central parts of the continent. Early on the 11th a large low-pressure or storm area passed eastward over Canada, southerly winds flowing into it, giving the high temperature observed here at noon of the 11th. But after the storm center passed further to the eastwarl we were subject to the cold westerly winds which flowed into the depression from the cold high-pressure area in the west, and which continued 
land if they are very deep. This is admirably illustrated in the slender lakes of central New York, about which the fruit-growing has disposed itself. The distance to which the ameliorating influence of the water may extend is determined very largely by the conformation of the shore lands. As a rule, there are distinct slopes towards the water, and it is rare that the effect of the water upon the temperature extends beyond the crest of the elevation. As a matter of fact, when the elevation is three hundred feet or more high, the region of immunity from frost ordinarily does not extend more than two-thirds of the distance to the summit. Along the central New York lakes, the area of the tender fruits, like grapes, does not reach more than half a mile, and at the utmost a mile, from the water. The famous Chautauqua grape-belt is confined to a strip about two to three miles wide lying upon Lake Erie, and reaching an elevation at its landward margin of less than

also during the 13th, as the storm center lingered over the northeastern coast. The fall of temperature at this Station from noon of the 11th to the 12ih was 40 degrees, and by the $13 \mathrm{th}, 50$ degrees.

"This cold wave appears to have differed from ordinary frosts in the following particulars: Frosts commonly occur on clear, calm nights, when the cold air sinks to the valley bottoms; but in this case the weather was clondy or partly eloudy, and strong westerly winds prevailed. The valleys, being protected from the wind, lost less of the soil warmth stored up during the preceding week than the higher and more exposed localities, which suffered most. The temperature fell to 32 degrees or below over northern and central New York generally on the 11 th, 12th and 13th, and probably we were saved from disastrous frost in the valleys and sheltered localities only by the warmth of the soil.

"I may add that the high-pressure area in the central states bronght severe killing frosts near Lake Michigan and the central valleys on the 9th and 10th. With us there was the added feature of the high winds, dne to the storm area as described." 
two hundred feet.* Along the eastern shore of Lake Michigan, the peach area extends all the way from one or two miles to fifteen or twenty, depending upon the conformation of the surface. Along the lower Hudson River the area of the tender fruits does not depart, as a rule, more than a mile from the stream. In very gradual slopes, the ameliorating inthenee of the water usually extends farther, but it is ant to be less marked than upon the lower parts of ahrupt slopes. In all these eases, the limit of the homndary of the area is determined by two factors,the distance from the water, and the elevation above it. Tarr, after studying the local geography of the Chautauqua grape country, makes the following observations upon the ameliorating inflnence of Lake Erie, and the remarks will apply to most other bodies of water: "The lake is a great modifier of climate. In the spring, by reason of the low temperature of its waters, it holds back the regetation, and this tends to keep it behind the ordinary frosts. Its very presence cheeks frosts by moderating the temperatme of the neighboring air. In the summer, the water tends to rool the air of the day and to keep the nocturnal temperature fairly high. During the fall, the water has been warmed by the summer sun, and the influence of this warm body of water lengthens the growing season and tends to keep off the early autumn frosts. There are many other influences, but nothing of importance ean be

\footnotetext{
${ }^{*}$ For a detailed account of the physiography of this region, see R. S. Tarr, Bull. 109, Cornell Exp. Sta.
} 
stated, excepting on the basis of a careful study extending over several years. The lake breeze of the day must moderate the daytime temperature; and the land breeze of the night may, in some eases, so keep the air in motion as to prevent frosts. That there is a marked influence upon climate as a result of the peculiar conditions of topography and neighborhood of water, is evident at the very first. Sketch maps show that the mean annual rainfall is greater on the escarpment than on the lake plain, and that the mean annual temperature of the hills is lower than that near the lake."

The particular influence which the water exerts over frost injury in spring is often due more to the retardation of the period of bloom than to the actual prevention of frost, although its influence in the latter direction is important. The lands adjacent to the water ordinarily warm up later in spring, and the trees are not likely, therefore, to swell their buds until danger of serious frosts is past. The amount of this retardation of bloom is often as great as ten to twenty days within a stretch of fifteen or twenty miles from a large body of water. It is well known that the danger from frosts is greatest in mild climates, in which "warm spells" are likely to occur in late winter or early spring. In the central and sonthern states, this frost injury following a period of warm weather is commoner than true winter-killing, whilst in the northernmost states and Canada serious injury to the trees from late spring frosts is comparatively infrequent. In the northern 
states, also, the plant goes into the winter in a perfeetly dormant and ripened condition, and is thereby able to withstand great cold. It has been said that injury from eold is more frequent in the Gulf states than in New York.

The elevation of any place also stands in elose relation to the frostiness of it. Perfectly flat lands are nearly always frosty, because there is no atmospheric drainage, a subject to which we shall soon recur. On the other hand, very high lands are also frosty, becanse the air is drier and rarer, and therefore allows of rapid radiation of heat from the land; and they are exposed to eold, nubroken winds. The local altitude to which the fruit lands may be carried ean be determined only by actual experiment; but in the north the best elevations for the tender fruits are nsually between 100 and 300 feet above the local rivers or lakes.

Whilst it is extremely important that the location for the growing of tender or early-blooming fruit should be seleeted with reference to its immunity from disastrous winter temperatures and untimely frosts, it should also be said that elimate is often held responsible for failures which are chargeable to ignoranee or neglect. This is particularly well illustrated in the perishing peach-growing of some parts of the north. It is a common complaint that peaches eannot be grown so easily as formerly. The writer has investigated this matter upon the eastern shore of Cayuga Lake, in central New York,*

* Bull. 74, Cornell Exp. Sta. 
a region which may be considered to be typical of the complaint that peaches are now particularly difficult to raise. "There are many theories to account for this failure. Oftenest, perhaps, it is attributed to change of climate, but we have no proof that any considerable climatic change has occurred, while it seems to be true that the northern peach frontier is holding its own, or is even advancing. In New York the failure is often attributed to yellows, that disease which seems to exist as a vague and indefinable alarm in the minds of the general agricultural population. Yellows and increasingly rigorous climate are said to have wiped out the peach growing of the Cayuga belt. Twenty years ago a million peach trees, it is said, could be seen upon the eastern shore from one point upon the west side, but now there are only a few scattered orchards. Here, then, may be found the secret of this strange falling off of the peach trees in all parts of the country in these recent years.

"Slanting towards the lake and pouring into it their drainage of water and cold air, laterally drained by deep ravines and protected from sweeping winds by lines of wood, these Cayuga lands seem to be admirably adapted to the peach. But the region had never been a peach belt, in the sense in which that term will apply to the best part of the Niagara district, or to the Lake Michigan belt, or the areas in more southern states. In other words, peaches had never been a leading industry there, but the orehards had been planted here and there near the lake as a 
very minor appendage to the general farming. For a generation or two of trees the insect pests were not common. There were no good markets, and the fruit sold as low as twenty-five cents a bushel from the wagon-box. In fact, it was grown more for the home supply than with an idea of shipping it to market. Under such conditions, it did not matter if half the crop was wormy, or if many trees failed and died each year. Such facts often passed almost unnoticed. The trees bore well, to be sure, but the crop was not measured up in baskets and accounted for in dollars and cents, and under such conditions only the most productive trees left their impress upon the memory. The soils had not undergone such a long system of robbery then as now. When the old orchards wore out, there was no particular incentive to plant more, for there was little money in them. Often the young and energetic men had gone west, there to repeat the history, perhaps, and the old people did not care to set orchards. And upon this contracting area, all the borers and other pests which had been bred in the many old orchards now concentrated their energies, until they have left scarcely enough trees in some localities upon which to perpetuate their kind. A new country or a new industry is generally frec of serious attacks of those insects which follow the erop in older communities. But the foes come in unnoticed and for a time spread unmolested, when finally, perhaps almost suddenly, their number becomes so great that they threaten destruetion, and the farmer looks on in amazement. 
"The cause of the failure of these early orchards, therefore, is the gradual dying out of the old system of agriculture and the coming in of special industries. The methods followed with success a generation and more ago are not profitable in the sharper competitions of the present time. At least, there is not the smallest evidence that there is any unusual or insurmountable difficulty in the way of peach growing in this once famous Cayuga region. The climate may be somewhat more bleak, but this difficulty may be lessened by the planting of shelterbelts; and there are enough protected places in which winds are not unusually severe. What yellows exists seems to have come in very recently. Good cultivation and attention to borers, and the other difficulties to which peaches are everywhere subject, will enable the people in that region to grow better orchards than were grown there in former times. This statement is proved by the partial suceess which is even now attending those parts of the seven remaining orchards which are receiving as much as indifferent care."

Winds and air-currents in relation to fruit-growing.-It is necessary that more specific attention be given to the subject of winds and eurrents of air, an inquiry which is suggested by the preceding remarks. There are the most varions and contradictory opinions amongst fruit-growers as to the influence of winds upon fruit plantations. It is commonly admitted that high or rolling lands are best suited to most fruits, and many growers sup- 
pose that the reason of it is that winds there find free eourse. The truth is, however, that several features conspire to render these lands congenial to fruits. Some of these characteristies are the following: (food atmospherie drainage; the avoidance of still air in frosty weatlur ; good water drainage; earliness or lateness, aeeording as they are southward or northward exposures. High or strong winds are always to be avoided, if possible, for they blow off the fruit and injure the plants.

As a rule, winds are beneficial to fruit plantations only when they bring warmer air, or when they keep the air in motion in frosty weather. If, therefore, high lands conld be protected from winds withont endangering atmospheric drainage of exposing the plantation to frost, much shonld be gained.

In dry regions there is a special reason for desiring to abate the winds, from the fact that they abstract so much moisture from soil and plants. Even a slight impediment in the path of the wind may give marked results in the eonservation of moisture. Upon this point, King* writes as follows:

"In arid or semi-arid countries, and in districts where the soil is light and leachy, but espeeially where there are large tracts of land whose ineoherent soils suffer from the drifting action of winds, it is important that the velocity of the winds near the ground should be reduced to the minimum. We have in Wiseonsin extensive areas of light lands which are now being developed for purposes of

* The soil, 204. 
potato culture; but while these lands are giving fair yields of potatoes of good quality, they are in many places suffering great injury from the destructive effects of winds. On these lands, wherever broad, open fields lie unprotected by wind-breaks of any sort, the clearing west and northwest winds after storms often sweep entirely away crops of grain after they are 4 inches high, uncovering the roots by the removal of from 1 to 3 inches of the surface soil. It has been observed, however, that such slight barriers as fences and even fields of grass afford a marked protection against drifting for several hundred feet to the leeward of them.

"In the case of groves, hedge-rows and fields of grass, their protection results partly through their tendency to render the air which passes across them cooler and more moist, and partly by diminishing the surface velocity of the wind. The writer has observed that when the rate of evaporation at 20 , 40 and 60 feet to the leeward of a grove of black oak 15 to 20 feet high was 11.5 ce., 11.6 ce., and 11.9 ce., respectively, from a wet surface of 27 square inches, it was $14.5,14.2$ and 14.7 at 280 , 300 and 320 feet distance, or 24 per cent greater at the three outer stations than at the nearer ones. So, too, a scanty hedge-row produced observed differences in the rate of evaporation, as follows, during an interval of one hour:

"At 20 feet from the hedgerow the evaporation was 10.3 ce.

\begin{tabular}{|c|c|c|c|c|c|c|c|}
\hline “ 150 & $" 6$ & $“$ & $" 6$ & $" 6$ & 66 & $" 6$ & 6 \\
\hline “ 300 & $" 6$ & " & 6 & $" 6$ & 16 & “4 & “ \\
\hline
\end{tabular}


"Here the drying effect of the wind at 300 feet was 30 per rent greater than at 20 feet, and 7 per cent greater than at 150 fert from the hedge.

"When the air came arross a clover field 780 feet widle, the observed rates of evaporation were:

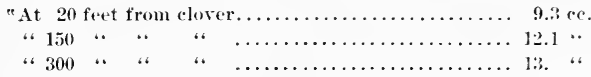

or 40 per cent greater at 300 feet away than at 20 feet, and 7.4 per eent greater than at 150 feet.

"The protective influenee of grass lands and the disadvantage of very broad fields of these light soils was further shown by the inereasingly poorer stand of young clover as the eastern margin of these fields was approached, even on fields where the drifting had boen inappreciable. Below are given the number of rlover plants per equal areas on three different farms, as the distance to the eastward of grass fields increased:

"No 1, at 50 feet, 574 plants; at 200 feet, 390 plants ; at 400 feet. 231 plants.

"No 2, at 100 feet, 249 plants; at 200 feet, 277 plants; at 400 feet, 193 plants ; at 600 feet, 189 plants; at 800 feet, 138 plants ; at 1,000 feet, 48 plants.

"No. 3, at 50 feet, 1,130 plants: at 400 feet, 600 plants; at 700 feet, 543 plants.

"In these eases the differenee in stand appears to have resulted from an inereasing drying aetion of the wind. On the majority of fields the destruetive effects of the winds were very evident to 
the eye, and augmented as the distance from the wind-breaks increased.

"It appears from these observations, and from the protection against drifting which is afforded by grass fields, hedge-rows and groves, that a system of rotation should be followed on such lands which avoids broad, continuous fields. The fields should be laid out in narrow lands, and alternate ones kept in clover and grass. Wind-breaks of suitable trees must also have a beneficial effect when maintained in narrow belts along line fences and railroads, and, perhaps, wagon roads, in places."

Budd writes* as follows respeeting the low windbreaks of Manitoba: "Professor N. E. Hansen and others recently made a trip to Indian Head and Brandon. He was surprised to find miles of low wind-break not over five or six feet in height to stop the sweep of the wind on the surface of the earth. These low hedges are made by planting the shrubby artemisia. This grows readily from cuttings stuck in early spring, and soon attains its final height. It is really proving a blessing in that land of winds, where even the wheat is blown out of the ground if the wind is permitted to hug the earth's surface. We found this a common shrub on the steppes of central Russia, and introduced it as an ornamental plant. The thought did not oceur that it would become the most popular wind-break of the wheat districts of Nanitoba and Northwest Territory."

Atmospheric drainage.-The air is rarely, if ever,

* Rural Life, 1896. 
perfectly still. This is well illustrated in the vagaries of light frosts, which touch here and there where the air is the stillest or the radiation most rapid. This is particularly true in the growing months, when the earth becomes very warm during the day and loses the heat rapidly at nightfall, and when, also, the sky is less overeast by clouds than it is in the winter months. After studying the disastrous frosts of Nay, 1895, in the Chautauqua vineyard district, Tarr wrote* as follows: "The behavior of this frost was altogether remarkable, leaving some districts or vineyards almost unharmed, and nearly ruining the crop in other's, while even in the same vineyard these extremes were sometimes noticed. This was probably chiefly due to eddies of the air, for even though air is almost quiet, it is still in meven motion. One may see this illustrated on a calm day by noticing the movements of a column of smoke. The air, being invisible, does not reveal these movements, and we become aware of them only when the conditions are exceptional, as when a frost is dealing out destruction to vegetation. The eondition of the ground also affects the frost, and the question whether it is dry or moist, freshly plowed or turf covered, whether there are trees or pastures or plowed ground in the neighborhood, all have their influence; but this subjeet has never been properly studied, and it is not possible to state just how these differences affect frost action."

Much of this unrecognizable movement of the air

*Bull. 109, Cornell Exp. Nta., 121. 
is due to the draining off or settling away of the cold air, which is densest, and therefore heaviest. It pours down the valleys of hilly and mountainous countries, and as its vapor condenses it gives rise to the valley fogs and clouds. It lies in the low places upon the farm, and there may cause frost. A person riding across an undulating country upon a still summer night can scarcely fail to notice the chillier air of the depressions. This escape of the cold air is the secret of much of the success of fruit-growing on rolling and sloping land; and this fact explains

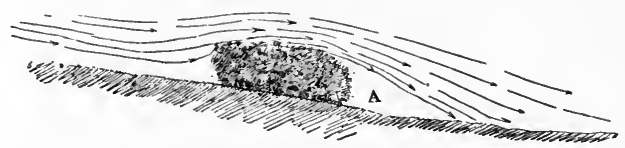

Fig. 1. The frosty belt below a wood upon a hillside.

the importance of giving great attention to the selection of the site and aspect when setting a plantation of the tenderer fruits.

Features of such little apparent importance as not to appeal to the fruit-grower often exert great influence upon the quiet movements of air. A frequent case is this: A strawberry field is upon a gentle slope, and on the upper side is a wood. In time of frost, the only injury occurs in a belt two or three rods wide just against the wood, in the very place where the greatest immunity was expected. This is because the slight bodily movement of the air down the hillside and over the forest 
strikes obliquely downward from the edge of the wood-top, and leaves a narrow belt of dead air against the timber (as at $\Lambda$ in Fig. 1, page 53.)

The atmospherie drainage is marked only in still air. Winds mix up the air, and bring it all to a comparatively uniform condition. The slightest obstaeles may sufficiently retard the movement to leave their impress in the distribution of a light frost. A rail fence, a stone wall, a row of bushes, a slight elevation of land, the earth thrown ont of a diteh,all of these are obstacles to drainage of cold air when they extend across a slope. In some aases, there may be a difference of ten degrees in temperature in as many feet of elevation. A dense row of trees standing diagonally across a slope may convey away the cold air which settles down against it, and thereby prevent injury to plants on the lower levels. It has been snggested that in certain hilly regions, levees a few feet high be built diagonally across the slopes, with ditches or moats above them to hold water, the evaporation of whieh would tend to raise the dew-point.

The range of elevation through which atmospheric drainage aets benefieially to the fruit-grower is limited. A fall of a few feet in a plantation is often sufficient for the very best protection from light frosts; and a fall of one or two hundred feet may be regarded as the general maximum throughont which the benefit may be observed, for very high elevations are, as we have seen, bleaker and colder in sum-temperature than comparatively low 
Temperatures on Hills.

\begin{tabular}{|c|c|c|c|c|c|c|c|}
\hline 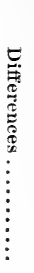 & 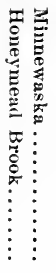 & 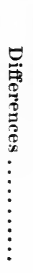 & 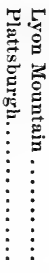 & 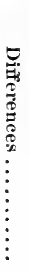 & 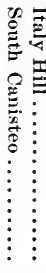 & & 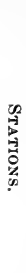 \\
\hline w & $\stackrel{+\infty}{\infty}$ & 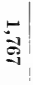 & تِ & 壱 & $\begin{array}{l}10 \\
ث \\
0\end{array}$ & $\underset{+}{\stackrel{7}{+}}$ & 蔦 \\
\hline 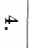 & is is & + & ثي & بن & $\Rightarrow$ & 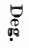 & ध艹 \\
\hline$\prod_{-1}^{0}$ & $\vec{E}$ & - & ن & نे & $=$ & 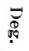 & $\stackrel{2}{2}$ \\
\hline i- & $\vec{\alpha}$ & بن & $\begin{array}{ll}-1 & \text { D } \\
\text { or is } & \end{array}$ & نَّ & $\vec{\infty} \underset{+}{\oplus}$ & 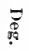 & $\stackrel{2}{*}$ \\
\hline$\sigma$ & $\begin{array}{l}\infty \\
\infty \\
\infty\end{array}$ & $\stackrel{+}{i}$ & $\vec{\oplus}$ & لَّْ & $\underbrace{0}_{0}$ & 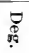 & 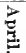 \\
\hline if & $\stackrel{N}{\stackrel{N}{*}:}$ & $\dot{\omega}$ & 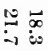 & 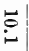 & $\begin{array}{l}\ddot{\theta} \\
\stackrel{0}{\circ}\end{array}$ & 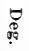 & $\frac{3}{4}$ \\
\hline is & $\underset{0}{心}$ & ن & آن & $\underset{ن}{\infty}$ & i⿱宀⿻心㇒丂 & 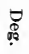 & $\stackrel{\breve{Z}}{\overparen{G}}$ \\
\hline o & $\stackrel{N}{N}$ & $\stackrel{\leftrightarrow}{+}$ & $\underset{i}{\stackrel{4}{+}}$ & هִ & $\underbrace{\infty}_{-1}$ & 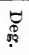 & 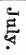 \\
\hline$\underset{\sim}{\mathrm{g}}$ & ث્ن & $\vec{i}$ & $\vec{\Phi}$ & iv & 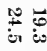 & 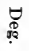 & $\stackrel{p}{g}$ \\
\hline$\stackrel{\infty}{\infty}$ & $\begin{array}{l}\vec{\alpha} \\
\text { iv }\end{array}$ & نे & $\overrightarrow{0}$ & $\stackrel{\infty}{\sigma}$ & $\stackrel{5}{5}:$ & 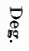 & 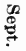 \\
\hline iv & $\vec{\infty} \underset{i}{\vec{\sigma}}$ & آن & $\begin{array}{l}\vec{\omega} \\
-\infty\end{array}$ & ب) & "ِ & 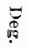 & م્ \\
\hline هُ & $\begin{array}{l}\vec{\alpha} \\
\vec{\infty}\end{array}$ & iv & 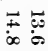 & is & $\vec{\omega}$ & $\underset{\mathbb{\infty}}{\ominus}$ & י4 \\
\hline$\frac{1}{2}$ & $\begin{array}{l}\overrightarrow{1}= \\
=\end{array}$ & io & 茫 & : & $\vdots \vdots \vdots$ & 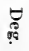 & 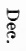 \\
\hline
\end{tabular}


ones are. That is, what may be gained by atmospheric drainage may be more than overeome by the coldness of elevation. The table (page 55) from the New York Meteorological Bureau*, eompares the monthly average temperatures of high and low stations. The high stations give, with but two slight exceptions, a lower reading than the low stations do, but the differences are least, as a rule, in the winter months, when the effeets of atmospherie drainage are apt to be least marked.

Thermometer readings taken upon the slope of East Hill, at Ithaca, New York, during January and February, 1897, also show the lower average temperatures of very high landst The top of this hill is about 400 feet above the valley. Six thermometers were plared along its slope, No. I. being at the foot of the hill, and No. VI. at its top. Temperatures taken at night would probably have shown more marked differences. It is probable, however, that if observations were made at night in still weather in spring or fall, between the valley and lands from fifty to one hundred feet above it, the higher lands would have given the higher figures, in eonsequence of the settling away of the cold air. It is well known, for example, that ravines along a fruit plantation often earry away the eold air and save the fruit from light frosts, and also that plantations opposite the mouths of gullies are likely to suffer. The Ithaea figures now follow:

\footnotetext{
* Fifth Ann. Rep. Meteor. Bureau, N. Y. 388.

t Male for me by my stulent, s. L. Sheldon.
} 


\begin{tabular}{|c|c|c|c|c|c|c|c|c|c|c|c|}
\hline & $\begin{array}{l}\text { Date, } \\
1897 .\end{array}$ & Hour. & $\begin{array}{c}\text { Ther. } \\
\text { I. }\end{array}$ & $\begin{array}{l}\text { Ther. } \\
\text { II. }\end{array}$ & $\begin{array}{c}\text { Ther. } \\
\text { III. }\end{array}$ & $\begin{array}{c}\text { Ther. } \\
\text { IV. }\end{array}$ & $\begin{array}{c}\text { Ther. } \\
\text { V. }\end{array}$ & $\begin{array}{c}\text { Ther. } \\
\text { VI. }\end{array}$ & 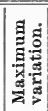 & 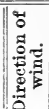 & 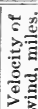 \\
\hline Jan. & 22. & $\begin{array}{l}\text { A. M. } \\
8.40\end{array}$ & $\underset{28}{\operatorname{Deg} .}$ & $\underset{27}{\text { Deg. }}$ & $\underset{27}{\operatorname{Deg} .}$ & $\begin{array}{c}\text { Deg. } \\
28\end{array}$ & $\begin{array}{c}\text { Deg. } \\
28\end{array}$ & $\begin{array}{c}\text { Deg. } \\
25\end{array}$ & $\begin{array}{c}\text { Deg } \\
3\end{array}$ & S W & 10 \\
\hline .6 & 23. & $\begin{array}{l}\text { P. H. } \\
12.25\end{array}$ & 26 & 24 & 25 & 23 & 22 & 23 & 4 & $\mathrm{~W}$ & 20 \\
\hline 66 & $25 \ldots$ & $\begin{array}{l}\text { P. M. } \\
2.15\end{array}$ & 10 & 8 & 9 & 7 & 6 & 8 & 4 & W & 30 \\
\hline 6 & $27 \ldots$ & $\begin{array}{l}\text { A. MI. } \\
8.45\end{array}$ & 13 & 12 & 13 & 13 & 12 & 13 & 1 & W & 1 \\
\hline Feb. & . 3. & $\begin{array}{l}\text { A. M. } \\
8.20\end{array}$ & 20 & 20 & 21 & 20 & 20 & 20 & 1 & $\mathbf{N} \mathbf{W}$ & $\mathbf{5}$ \\
\hline$" 6$ & $4 .$. & $\begin{array}{l}\text { A. } \mathrm{M} \text {. } \\
11.45\end{array}$ & 31 & 26 & 28 & 27 & 31 & 27 & 5 & $\mathbf{N}$ & 2 \\
\hline$" ،$ & $4 \ldots$ & $\begin{array}{l}\text { P. M. } \\
5.45\end{array}$ & 25 & 24 & 24 & 24 & 25 & 27 & 3 & $N$ W & 2 \\
\hline “ & 6. & $\begin{array}{c}\text { A. M. } \\
9.00\end{array}$ & 35 & 35 & 35 & 36 & 35 & 33 & 1 & S E & 13 \\
\hline “" & 8. & $\begin{array}{l}\text { A. M. } \\
8.00\end{array}$ & 37 & 33 & 33 & 33 & 32 & 33 & 4 & W & 4 \\
\hline “ & 9. & $\begin{array}{l}\text { A. M. } \\
8.00\end{array}$ & 31 & 29 & 29 & 28 & 28 & 28 & 3 & W & 5 \\
\hline$“$ & 22. & $\begin{array}{l}\text { A. M. } \\
8.00\end{array}$ & 33 & 31 & 32 & 34 & 34 & 30 & 4 & S E & 2 \\
\hline$“$ & $23 \ldots$ & $\begin{array}{l}\text { A. M. } \\
9.00\end{array}$ & 38 & 35 & 35 & 36 & $\cdots$ & 34 & 4 & S W & 12 \\
\hline$*$ & $24 \ldots$ & $\begin{array}{l}\text { A. M. } \\
8.30\end{array}$ & 25 & 21 & 22 & 21 & 22 & 21 & 4 & $\mathrm{~S} \mathrm{~W}$ & 8 \\
\hline "، & 26. & $\begin{array}{l}\text { A. } \mathrm{M} \\
8.15\end{array}$ & 19 & 13 & 17 & 14 & 14 & 14 & 5 & W & 10 \\
\hline “ & $27 \ldots$ & $\begin{array}{l}\text { A. M. } \\
8.30\end{array}$ & 17 & 14 & 16 & 14 & 15 & 13 & 4 & W & 4 \\
\hline Mar. & . 1. & $\begin{array}{c}\text { A. M. } \\
8.30\end{array}$ & 16 & 13 & 14 & 13 & 16 & 12 & 4 & $\mathrm{~S}$ E & 12 \\
\hline \multicolumn{3}{|c|}{ A rerage temp. } & 25.25 & 22.81 & 23.75 & 23.18 & 22.66 & 22.56 & 2.69 & & \\
\hline
\end{tabular}


THE SITE FOR THE FRLIT PLANTATION.

As a rule, especially in northern countries, the ideal site for a fruit plantation is one which is somewhat elevated above adjoining lands. Such a site presents the two advantages of atmospheric and soil drainage. Of these atvantages, the atmospherie drainage is the greater, inasmuch as soil drainage ran be secured by artificial means. Cold air, being heavier than warm air, in still weather settles into the lowest areas, as we have alrady seen, often ratusing, upon such lands, serious late spring and rarly fall frosts, as well as reducing the temperature in winter. In speaking of elevated lands, it is not necessarily moant that they be rolling. Some entire farms which are almost flat may be sufficiently elevated above the local streams or the general eontour of a flat comntry to answer all purposes of an ideal fruit site.

A comparatively slight elevation is often sufficient to accomplish perfect atmospheric drainage, particularly if the adjacent lower lands slope sufficiently to allow the cold air to gradually drain away. Sometimes a sharp deeline of ten or fifteen feet along one side of a plantation is sufficient; or, a gradual and gentle slope throughout may be equally alvantageons. More pronounced elevations usually give more marked results, however, and for this reason they are preferred for the tenderer fruits.

The pronommed minor elevations often present other advantages of temperature than those incident 
to atmospheric drainage. They offer various exposures, and they may be utilized as wind-breaks by placing the plantations on the slopes opposite the severest winds. If they are near large bodies of water, they are usually more profoundly influenced by such bodies than flatter lands, because more open to the movements of air from them; and as bodies of water tend to equalize temperature, to lessen late spring and early fall frosts, it follows that high lands near lakes and great rivers are most desirable for fruit-culture. The exact amount of exposure which the fruit-grower may find advantageous must be determined for each individual case after a thorough study of all the local conditions; and in this investigation the discussion of wind-breaks, beginning on page 62 , may be suggestive.

Despite all these remarks, there are certain cases in which comparatively low lands are preferable for fruit-raising, but this is because such lands are moister, richer, leveler, or more sheltered, rather than because they are lower than surrounding areas; for all these advantages may sometimes be secured on comparatively elevated lands, and atmospheric drainage be secured in the bargain. Strawberries are grown on lower lands largely because such lands are moist and level. Quinces and blackberries demand a moister land than is usually found upon pronounced slopes. In any event, however, the grower should avoid flat lands which are hemmed in on all sides by elevations, for these "pockets" are nearly always frosty. 
The aspert.-The aspect or exposnre of a fruit plantation is determined by the direction and extent of the slope of the land. The exposure exerts great influener upon the temperature of the soil and upon the force of the winds, and it therefore beromes an emphatic problem in the loeation of a fruit plantation, especially when the tender and earlyblooming fruits are under eonsideration. There is the greatest diversity of opinion resperting the proper exposure for fruits, some growers eontending that the northward slope is always the best, and others preferring a southward exposure. The truth is that no one exposmre is best in all cases. Much depends upon the location and the particnlar environment of the plantation, and upon the kind of fruit which it is proposed to grow. The subject may be elueidated by diseussing it under three generalizations:

1. In locations adjoining bodies of water, the best slope is towards the water. The very reason for the location of fruit farms in such places is that the ameliorating effects of the water may be secured, and these effects are most marked when the fruit land slopes direetly towards the river or the lake. In all these eases, therefore, the partirular direction of the slope in respect to the points of the rompass is of a very secondary importance. There is often great choice between the two sides of a river or small lake, particularly when the slopes are sharp and high. That side which faces away from strong prevailing winds is 
generally preferable, particularly if the elevation back of it is sufficient to act as a wind-break.

2. In interior or frosty regions, the best slope for the tender and early-blooming fruits, as a rule, is one which retards the blooming period, thereby cansing the plant to remain comparatively dormant until after the incidental spring frosts are passed. In such places, therefore, the northward and westward slopes are generally most advisable; although if these slopes are too pronounced, they may be so very cold and backward that what is gained by the retardation in spring may be lost by the retardation in fall, and the fruits may fail to ripen properly, or be canght by early fall frosts. In wholly interior places, a somewhat pronounced northward exposure is usually preferable for peaches and apricots, since these fruits are likely to swell their buds with the first fitful warmtl of spring

3. If one desires to secure particularly early results and bright colors of fruits, a warm and sunny epxosure, to the southward or southeastward, is most advisable. This is a matter of considerable moment with the finer dessert varieties of fruits.

It is sometimes necessary, also, to study the exposure with reference to prevailing winds, when these winds are more or less constant and strong. The selection of the aspect may, in a large measure, obviate the necessity of establishing elaborate wind-breaks. The contour of the land should always be carefully considered when the planting of shelter belts is under advisement. 
WIND-BREAKS FOR FRIIT PLANTATIONS.*

We are now able to approach the troubled subject of wind-bleaks in an analytic spirit. Although the best writer's upon horticultural topics are nearly manimons in recommending wind-breaks for all fruit plantations, there is, nevertheless, wide difference in opinion and practiee among good cultivators conrerning thenl. Fruit-growers, as a rule, hold deeided opinions concerning wind-breaks. In fact, they usually hold extreme opinions, either wholly opposing shelter belts in all cases, or positively advoeating them. All who are engaged in the growing of fruits or who attend fruit-growers' gatherings, have heard the most positive experiences cited in support of both opinions. There must be good reasons for these opposing views. There appear to be no wellgrounded maxims or precepts among growers themselves, and statements concerning the merits of sheltrr belts are commonly vague. In order to arrive at the best rument opinion upon the subject, many" inquiries have been made and fruit farms have been visitral. Three hundred cirenlars were addressed to loaling frnit-growers in Now York and Michigan, asking for definite information in regard to windbreaks. Seventy-seven replies were obtained. This is a large proportion, and the number may be assumed to include all the persons of the three hum-

* This disenssion is founded upon the author's "Study of Wind-breaks in Their Relations to Fruit-growing." Bull. IX., Cornell Exp. Sta. (1889); also "Wind-breaks for the Fruit-grower," Proc. Hich. Forestry Conv., held at Grand Rapids, Jan. 26 and $27,18 \times 8$. 
dred addressed who have had experience, or have made direct observation. Forty-eight of these replies relate definite results. It is probable that nearly the whole range of experience with wind-breaks in reference to fruit-culture in the northeastern states is represented in these letters. Two general categories may be made,-those favoring the use of wind-breaks for fruit plantations, and those opposing them. Each of these eategories may be again divided into replies relating definite experience, and those detailing only general observation or opinion.

An epitome of the benefits reported in the tables on pages 64-68 may be made as follows (stated somewhat in order of importance):

1. A wind-break may protect from cold.

2. Rednces evaporation from the surface of the soil, tending to mitigate dronght in summer and root injury in winter.

3. Lessens windfalls.

4. Lessens breaking of trees laden with fruit or ice.

5. Retains snow and leaves, thus tending to prevent deep freezing and excessive evaporation.

6. Facilitates labor in the fruit plantation.

7. Protects blossoms from severe winds.

8. Enables trees to grow straighter.

9. Reduces injury from the drying of small fruits on the plants.

10. Holds the sand in certain sections.

11. Sometimes causes fruits to ripen earlier.

12. Encourages birds.

13. It can be made an ornament. 


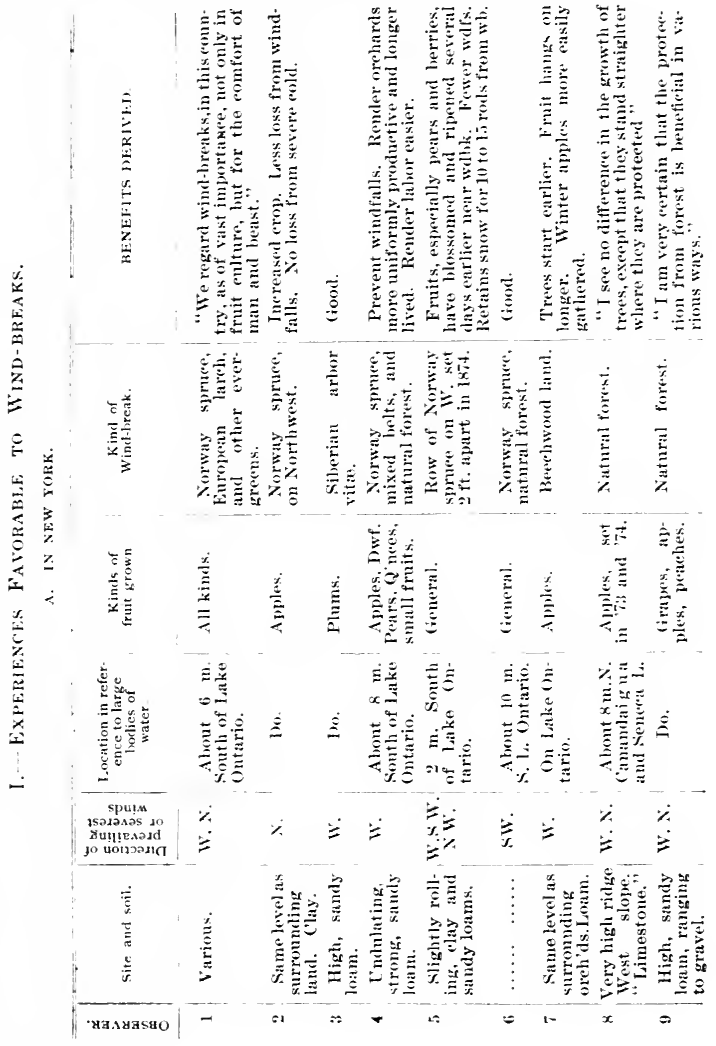




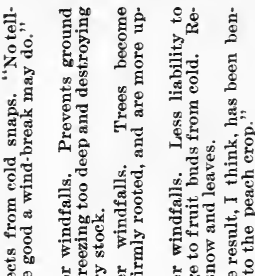

¿ृं

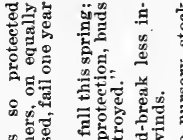

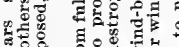

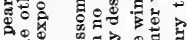

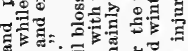

क

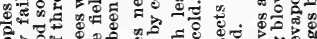
द⿳宀一𠃌

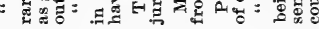

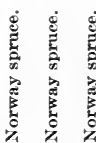

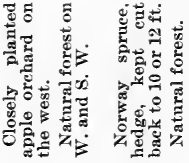

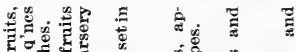

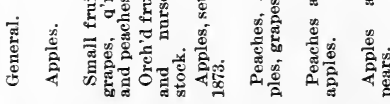

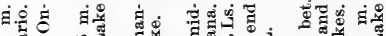

륭

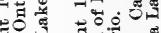

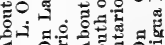

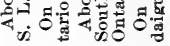

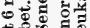

$+\infty \Phi$ 两

일
นิ

ق छ

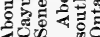

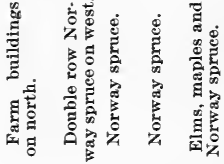

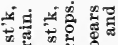

$\rightarrow$ of $\rightarrow-3$

के

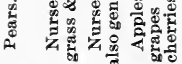

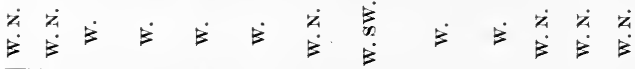

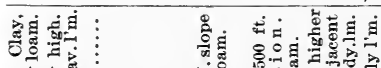

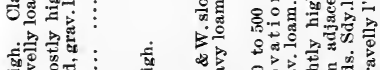

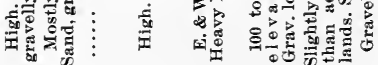

음 


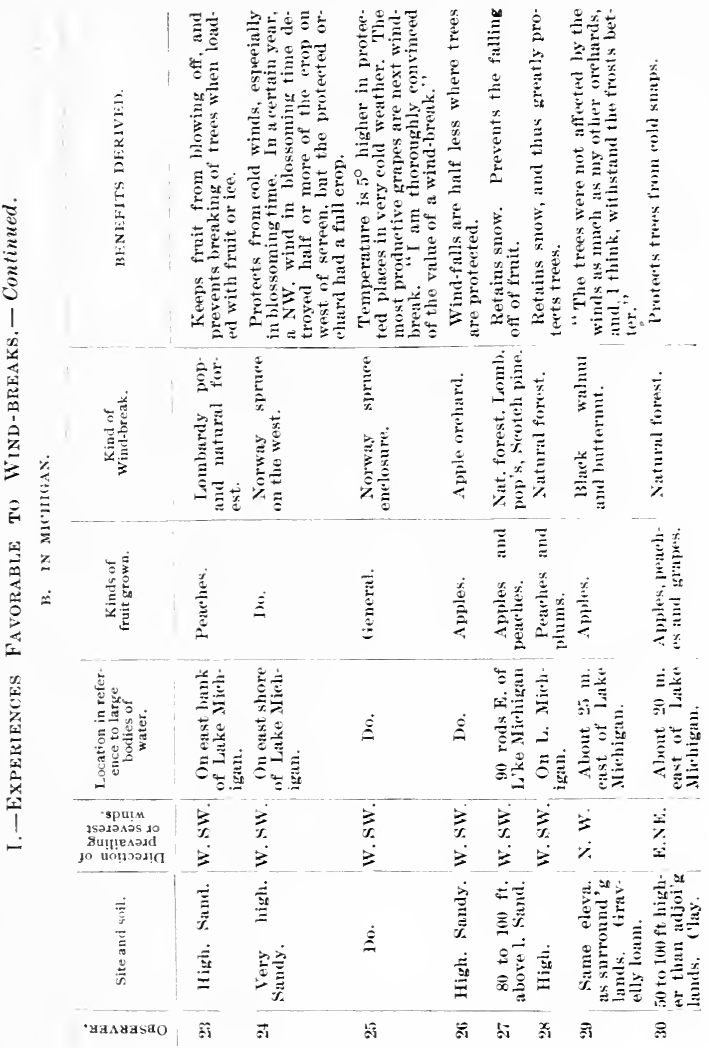


Experiences with Wind-breaks.

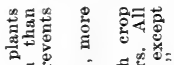

$=\frac{1}{8}$ 竞.

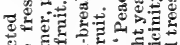

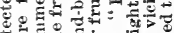

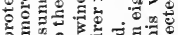

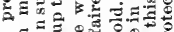

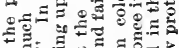

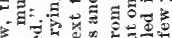

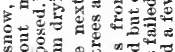

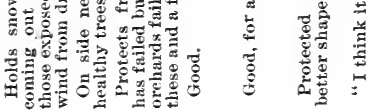

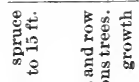

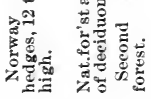

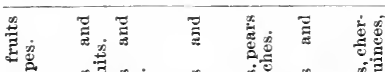

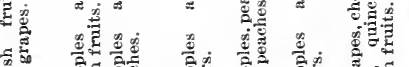

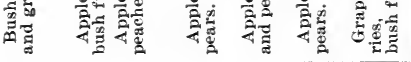

ㅎํำ

क.

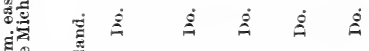

虫产

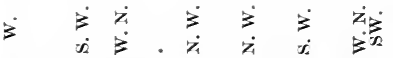

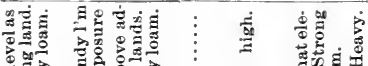

数

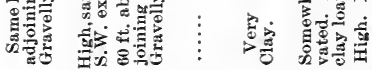

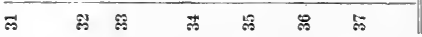

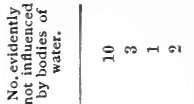

हैं

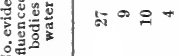

z.

ลิํํㄹ

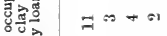

z.

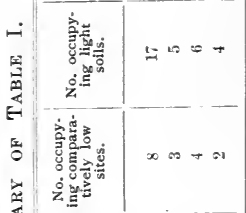

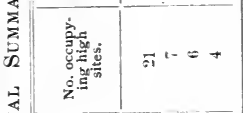

迹

额

$\underset{5}{0}=0$

乙。

岱

$\therefore \underset{3}{3}$

要

药

$\vdots$ का क्ष

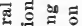

进

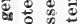

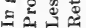




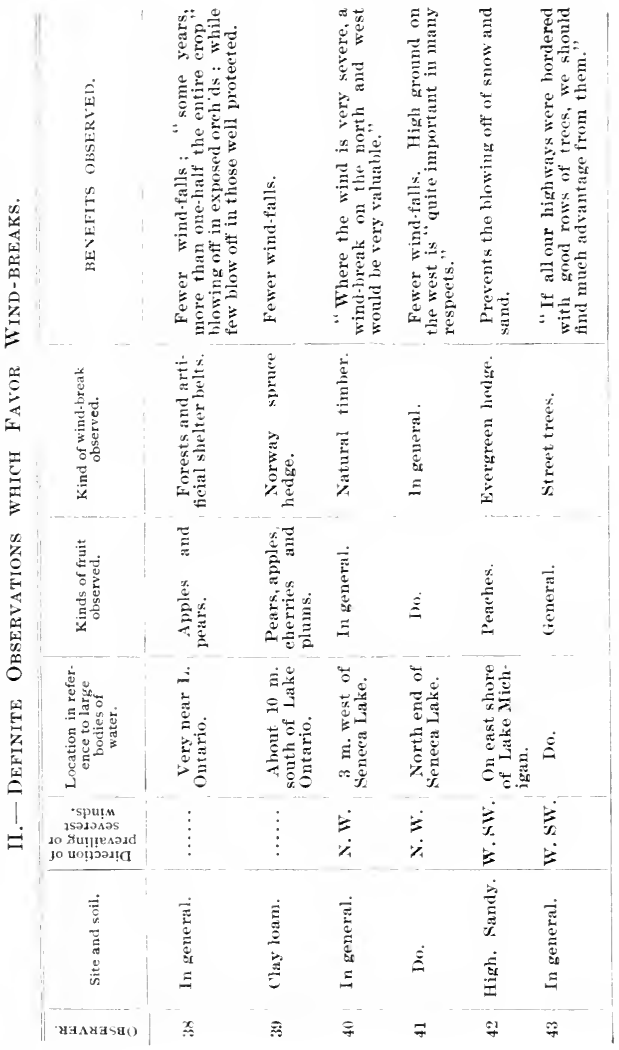


Injuries from Wind-breaks.

69

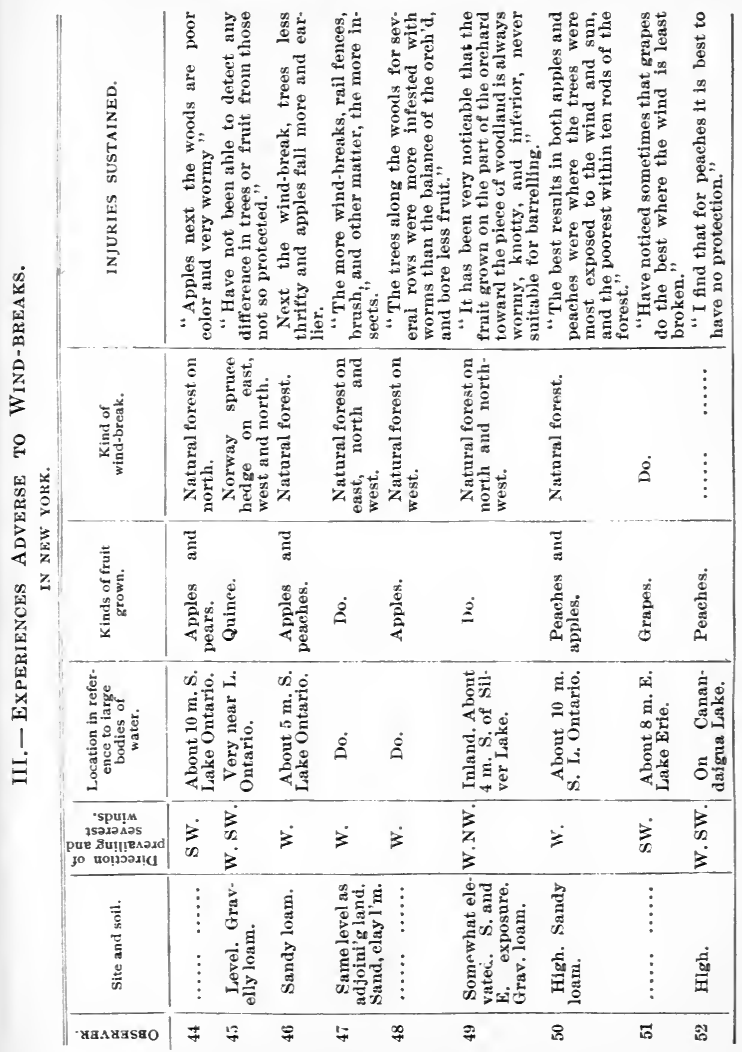




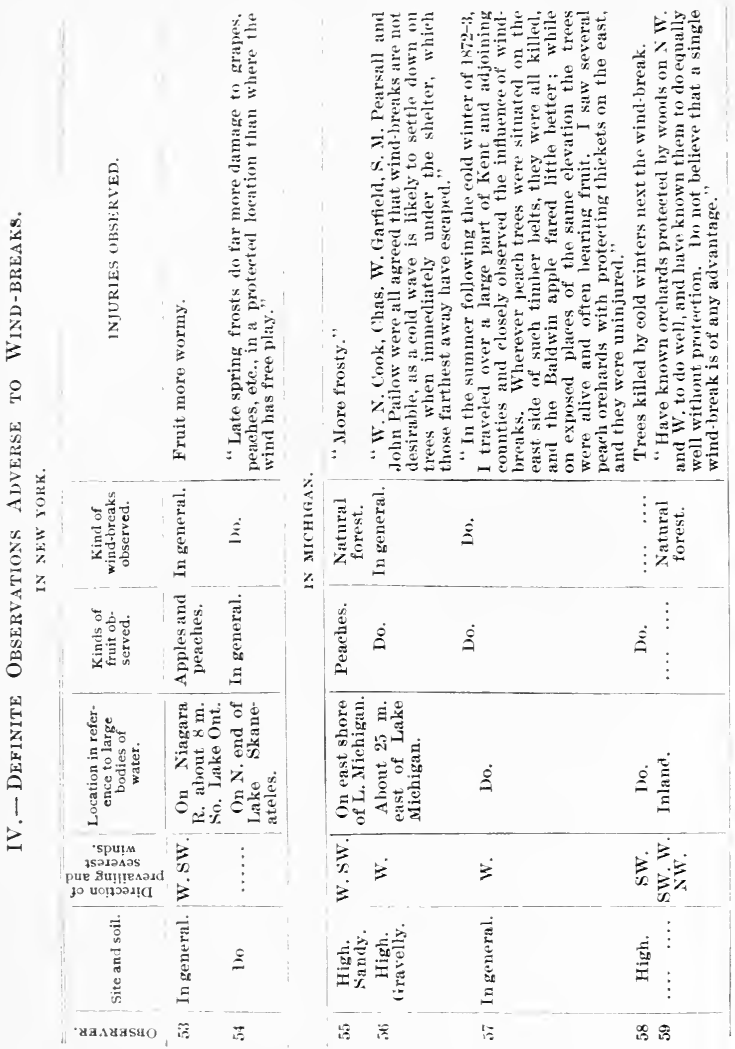


Epitome of injuries from wind-breaks (pp. 69, 70):

1. A wind-break may render a plantation colder at certain times.

2. Fruit immediately adjoining the wind-break is apt to be much injured by insects and diseases, and to be small and inferior in color.

3. Trees immediately adjoining the wind-break are often less thrifty than others.

4. There may be greater damage from late spring frosts in sheltered plantations.

Statements of authors.-In connection with the foregoing reports, it will be well to review the statements of various writers respecting the use of wind-breaks :

It [the fruit garden] should be screened on the north and the east, either by high walls and fences, or, what is far better, either by hills or a deep and dense border of evergreen or other forest trees, intermixed with fruit trees and shrubs of ornament.-Kenrick, New American Orchardist, IX. (1832).

As our native forests become cleared away the climate is changed and becomes more harsh; henee it is found desirable to construct some kind of protection from the point of most destructive harsh winds and storms. Belts of trees, either evergreen or deciduous, or both mixed, and surrounding or placed so as to screen from the northeast, north and northwest, are considered highly advantageous.-Downing, Fruits and Fruit Trees of America, 54.

The atmospheric changes and conditions we cannot control, and we can modify them only in a very limited degree, by hedges, by timber belts, and by evergreen sereens, the value of which begins to be appreciated.-Warder, American Pomology, 207. 
In localities exposed to the sweep of winter winds, belts of evergreen or deeiduous trees will be found of great service. In all instances where the side of an orehard exposed to the prevailing winds is less snccessful and productive than the opposite side, proof is afforded that shelter would be beneficial; belts, espeeially if of deciduous trees, standing too near fruit trees, have, however, rather injured than benefited them. The orehard shonld be beyond the reach of their shade and roots, and be well exposed to sun and air.-Thomas, Fruit Culturist, new ed., 48.

If possible, a situation should be elosen where some natural obstaele, as a hill, or a belt of woods, wonld break the force and influence of these destructive winds. Where no such obstacle naturally exists, a belt or border of rapidly growing trees * * * sliould be planted simultaneously with the planting of the orchard. * * * * Instances oecur every year in our own section where sheltered orehards bear full erops, whilst those fully exposed to the winds fail entirely.-Barry, Fruit Garden, new ed., $1 \% 6$.

Although having an orchard elosely pent up by trees, ete., is injurions, nevertheless a sereen of forest trees, at sneh distance from the fruit trees as that the latter will not be shaded by them, is of very great service in protecting the trees in spring from severe cold winds-Bridgeman, Gardener's Assistant, by Todd, II., 39 .

A few orehards, in speeially bleak situations, need proteetion from winter winds, but all orehards need wind-breaks toward pieking time. The damage done in exposed orchards by the blowing off of fruit before it is reached by the pickers may amount to 50 per cent of the entire value of the erop, or even more. Belts of natural timber furnish most protection; but they are apt to be the breeding grounds of noxious inseets. A thick row of arbor vita (white cedar), like that shown in Fig. 2, is easily grown, and furnishes ample proteetion. This oceupies some land, however, and sueh dense belts of evergreens interfere serionsly with atmospheric drainage (the rapid evening flow of eold air off the land to lower ground). This is a most impor- 
tant consideration. Very satisfactory results have been secured in young orchards by planting between tree rows, and in encireling belts, with tall growing, western dent corn. It is practicable in some cases to plant Northern Spy on the more exposed sides of the orchard. This variety makes large trees, which protect the remainder of the planting, while the fruit holds on much better

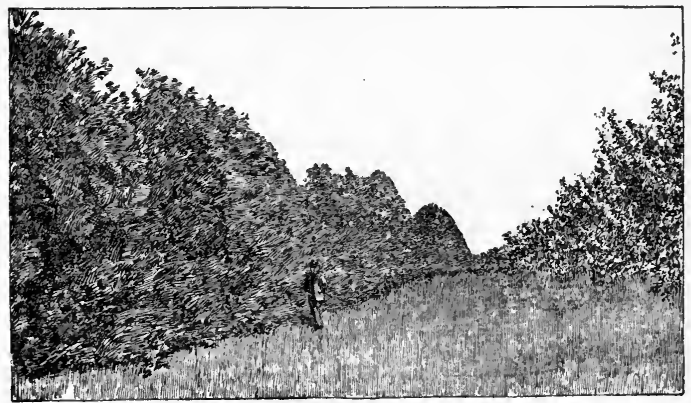

Fig. 2. An arbor vitæ wind-break. (Adapted from Waugh, Bulletin 55, Vermont Exp. Sta.)

than in other varieties, and is comparatively undamaged by the wind.-F. A. Waugh, Apple Growing in Grand Isle County, Bulletin 55, Vermont Exp. Sta.

As the young wood and fruit buds [of the peach] often suffer from the piereing blasts of winter, a spot that is sheltered from these is much to be desired. And, as they usually come from the north and northwest, a site on the south or southeast of a wood or hill is, other things being equal, greatly to be preferred. - Fulton, Peach Culture, 68.

To shelter an orehard from the prevailing wind is often more important even than the aspect; for pear trees, especially when heavily laden with fruit and exposed to a wind storm, will suffer 
more injury from being shaken than from an ordinary late frost. * * * * The evergreens should be planted in lines parallel with the pear rows, and they will more than pay for the ground they occupy in protecting the fruit trees from heavy gales.Quinn, Pear Culture for Profit, 19

It is within the power of man greatly to modify the character of a situation by the judicious planting of belts of evergreens, by a wise addition of elements and a proper culture of the soil. and by encouraging the shade of the vineyard itself wherever rircumstances indicates its necessity. - Strong, Culture of the Grape, 101.

In general, it will be found necessary to secure protection on the west, north and nortbeast. $* * * *$ No defense is better than a good belt of Norway spruce, and if they form a crescent in which the vineyard is embowered, but little danger need be apprehended from violent winds.-Phin, Open Air Grape Culture, 40 .

If the land las no protection from the north and northwest, see what the facilities are for supplying one either by walls or a belt of trees. If trees are to be used, evergreens are best. $-F u l$ ler, Grape Culturist, 89.

The location [for the vineyard] should be sheltered from the cold winds from the north and northwest.-Husmam, cuiture of the Native Grape, 43.

An artificial wind-break of this kind ["in the shape of an L, sometimes a perfect square," generally of cottonwoods, of the style prevalent in the west] is an excellent thing for the buildings, and it should embrace several acres, but for protection to the orchard it is worse than useless. In a quiet, warm day in late winter these groves reflect the sun's rays, and, if continued for some days, will either start too early a growth, which is soon to freeze up again, or the freezing and thawing of the bark kills it in patches, and we have the next summer the evidence in the sloughing off of the bark on the sunny side, followed by decayed wood and a consequent swarm of borers, which take possession, 
and death soon follows. It is generally coneeded now by practical orchardists that these wind-breaks are detrimental to the fruit trees, but we are frequently asked what we are to do to prevent the fruit from blowing off. We answer by asking what prevents this in an orchard of several hundred acres in extent?* Adam says that the best wind-break is "another row of trees." If it is determined to have this wind-break, why not make it of the Haas apple?-C. W. Gurney, Northwestern Pomology (Concord, Nebraska), 59 .

A free circulation of air is very desirable in an orchard, and full exposure is better than shutting in too elosely, yet in a full exposure is not found the best condition for a successful orehard. It should be surrounded with wind-breaks on the exposed sides, sufficient to somewhat break the force of the wind, but not heavy enough to prevent a good cireulation of air through the orehard at any time. It is much more important to have a wind-break on the south and west sides of an orehard than on the north or east, for it is from the former directions that come the most injurious winds.-Samuel B. Green, Amateur Fruit-growing (Minneapolis), 74 .

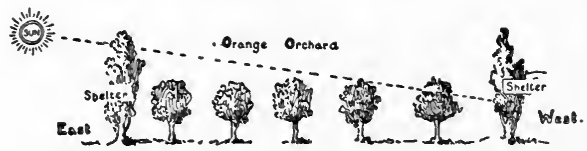

Fig. 3. Protection of an orange grove from the morning sun.

Though the elimate of California renders unnecessary the protection against rigorous weather which fruit-growers in some other parts of the world have to provide, there is often advantage in securing shelter from winds and protection from late frosts.

* The outside rows act as wind-breaks. The larger the orchard, the less is the injury to the interior parts of it by wind. An orchard may be very completely protected by another one standing to the windward.-L. H. e 
* * * It has already been remarked that on the immediate eorst the suecessful growth of fruit will sometimes be wholly dependent upon proper shelter from prevailing winds, and in regions farther from the ocean the topography may induee strong currants of air, which will ill affect trees and vines. In all such places the fruit-grower should plant wind-breaks, and will find himself well repaid for the ground they occupy, by the suecessful production on the protected area. In the interior valleys there is also need of shelter from oceasional high winds, which may visit the orchards either in summer or winter, and prove very lestructive both to trees and fruit.-Wickson, California Fruits, $55 \%$.

At Rivers [California] our orange groves are subject from Oetober to Mareh to so-ealled "northers," a wind blowing from due north, and usually for three days and nights eontinuously. When orehards are not protected from these winds, the injury some seasons amounts to fully 75 per eent of the whole erop. Have also found that when the shelter belt was planted on all sides, and that on the east side was tall enough to shelter the orehard from the first rays of the morning sun, the injury from frost was only perceptible in the branehes first exposed, while in orehards without the shelter on the east side, the damage was quite marked throughout the orehard. The diagram (Fig. 3, page 75) illustrates my meaning and experienee. The top of the tree at the right was nipped by frost, whilst those at the left escaped. The Eucalyptus globulus (Blne gnm), schinus molle (so-ealled Peppertree), and the Monterey cypress are all used for shelter belts; the last named is the best. ${ }^{*}-H$. J. Rudisill, in American Garden, XI., 563.

Do not loeate where your orehard will be exposed to severe winds. Quite a large proportion of fruit is lost every year by being whipped against thorns and branches, and the trees themselves are sometimes half stripped of leaves. If you have reason

* The reason for the escape of the trees is, no doubt, the fact that the high shelter shaded the grove in the morning, preventing the sun from striking directly upon the frosted trees.- L. H. B. 
to apprehend an occasional wind storm, plant a double row of eucalyptus, pepper or eypress trees about the orehard for a windbreak.-Spalding, The Orange: Its Culture in California, 40.

A place free from strong winds is best, but some that are subject to them are otherwise exceedingly desirable. Some windy places have been proved to be the best in other respects for orange culture. If orchards be planted in places subject to wind, wind-breaks should be planted at once.-Garey, Orange Culture in California, 18.

The frequent diseussion of the subject [advantages of partial forest shelter] * * * among orange-growers, its importance to all, and especially its importance to many portions of the state [Florida] where suceess must ever depend upon either forest or some artificial protection, demands careful attention. Many persons have heretofore considered it unnecessary, and the idea even absurd. But years of experience and observation, and especially the experience of the winter of 1876-7, have made many eonverts.-Moore, Treatise and Hand-book of Orange Culture, $3 d$ ed., 54 .

Forests and fruit-growing.-One of the reasons why fruit-growing is attended with increasing difficulties is because the forests have been destroyed, causing the country to become drier and hotter in summer and bleaker in winter. Forest, then, aids the fruit-grower in two important respects: 1 . It prevents the disastrous effects of sweeping winds. 2 . It conserves and regulates atmospheric moisture.

It is very doubtful if the extremes of temperature or fluctuations in annual means are more intense in recent years from the effects of forest removal. It may not even be true that there are more high winds now than formerly, but it is true that winds sweep over the farm with greater force. 
Winds sweep the surface and bear away the moisture of the soil at the same time that they come in contact with the trees and bushes themselves, and take away their moisture. The chief effect of the forest is to check the force of winds in prescribed areas. It has a local influence. Aside from all this, if forests were retained about the sources of creeks and upon springy hillsides, a more continuous supply of water might be obtained for irrigation, stock, spraying and domestic uses. It is worth saying, too, that a country which is dotted here and there with forest areas is a much more attractive one, to every person who loves variety of landscape and nature, than one which has been reduced to a dead sameness by the removal of all timber.

Whilst there are thus many advantages to fruitgrowing of small forest preserves, there are also disadvantages. In certain cases they may become the harbors and rallying places of serious insect or fungous invasions. This difficulty may be largely avoided by cutting out those trees and bushes which breed the fruit-grower's enemies. The wild cherries are much loved of the tent caterpillars, the elm of the canker-worm, and wild roses and their kin of the rose-chafer. The redar-apple fungus thrives upon the red cedar, and is thence transported to the quince or apple orchard, and a form of it affects the wild thorn trees. The red-rust flourisbes upon the wild blackberries, dewberries and black raspherries, and the strawberry diseases breed 
upon the patches of wild berries. It is not often, however, that the forest areas become a very serious menace to fruit-growers.

Revieu of the influences of uind-breaks upon fruit plantutions.-The benefits derived from wind-breaks are numerous, most positive in character, and appear to possess sufficient importance to warrant the strongest recommendations of horticultural writers. Yet the injuries occasionally sustained in consequence of shelter belts may be serious, for it is a well attested fact that trees sometimes suffer from cold in the immediate vicinity of a dense wind-break when they escape injury in other places. This fact is easily explained, however. The influence of a wind-break upon the temperatures of an adjacent plantation is governed by its position with reference to prevailing or severe winds. Of itself, wind probably exerts little or no influence upon temperature. It acquires the temperature of surfaces over which it passes. If these surfaces are colder than the given area, cold winds are the result, or if warmer, as a large body of water, the winds are warm. But wind often canses great injury to plants because of its acceleration of evaporation; and winds which are no colder than the given area, if comparatively dry, may consequently do great damage to fruit plantations. This is particularly true at certain times during the winter season. Land winds, being cold and dry, are therefore apt to be dangerous, while winds which traverse large bodies of water, and are therefore comparatively warm and 
moist, are usually in themselves protertors of tender plants. The following table, giving the average temperature of different winds at New Haven, Connocticut, as compared with the mean temperature of that place, shows that those winds which blow off the Sound are much warmer than the land winds: *

\begin{tabular}{c|c|c|c}
$\begin{array}{c}\text { Direction of } \\
\text { wind. }\end{array}$ & $\begin{array}{c}\text { Average above the } \\
\text { mean temp. }\end{array}$ & $\begin{array}{c}\text { Direction of } \\
\text { wind. }\end{array}$ & $\begin{array}{c}\text { Average under the } \\
\text { mean temp. }\end{array}$ \\
\hline Southwest .... & $+4^{\circ}$ & Northeast.... & $-.6^{\circ}$ \\
South........ & $+3.2^{\circ}$ & West ........ & $-1.1^{\circ}$ \\
Southwest.... & $+1.2^{\circ}$ & North........ & $-2.7^{\circ}$ \\
East......... & $+.5^{\circ}$ & Northwest ... & $-4.5^{\circ}$
\end{tabular}

The mitigating influence of bodies of water is familiar; the following figures will serve to show the extent to which they modify the mean temperature of the four coldest months: $\dagger$

$$
\text { A. -IN NEW YORK. }
$$

\begin{tabular}{|c|c|c|c|c|c|c|c|c|}
\hline S'TATIONS. & Dee. & Jan. & Feb. & Mar. & $\begin{array}{l}\text { Aver- } \\
\text { age. }\end{array}$ & $\begin{array}{l}\text { Lati- } \\
\text { tude. }\end{array}$ & $\begin{array}{l}\text { Eleva- } \\
\text { tion. }\end{array}$ & $\begin{array}{c}\text { Period of } \\
\text { olservation. }\end{array}$ \\
\hline Fredonia..... & 30.8 & 28.7 & 27.4 & 35.3 & 30.55 & $42.26^{\circ}$ & $709 \mathrm{ft}$. & $1830-1848$ \\
\hline Rochester... & $28 . \overline{3}$ & 26. & 26.4 & 33.1 & 28.5 & $43.0 \pi^{\circ}$ & $506 “$ & $\left\{\begin{array}{l}1830 \\
1833-1853\end{array}\right.$ \\
\hline Anburn ...... & $29 . \overline{5}$ & 24.4 & 24.6 & 33.5 & 28. & $42.55^{\circ}$ & $650 *$ & $1827-1849$ \\
\hline Etica $\ldots \ldots$ & 26.8 & 23.3 & 23.4 & 32.3 & 26.45 & $43.06^{\circ}$ & 4736 & $1826-1848$ \\
\hline
\end{tabular}

*Loomis' Heteorology, 88.

† Compiled from Blodget's Climatology of the United States, 38. 
B. - IN MICHIGAN.

\begin{tabular}{|c|c|c|c|c|c|c|c|c|}
\hline Stations. & Dec. & Jan. & Feb. & Mar. & $\begin{array}{l}\text { Aver- } \\
\text { age. }\end{array}$ & $\begin{array}{l}\text { Lati- } \\
\text { tude. }\end{array}$ & $\begin{array}{l}\text { Eleva- } \\
\text { tion. }\end{array}$ & $\begin{array}{c}\text { Period of } \\
\text { observation. }\end{array}$ \\
\hline Detroit ..... & 26.9 & 27. & 26.6 & 35.4 & 28.97 & $42.2^{\circ}$ & $580 \mathrm{ft}$. & $\left\{\begin{array}{l}1836-1846 \\
1849-1851\end{array}\right.$ \\
\hline Fort Gratiot. & 26.6 & 25.3 & 25.3 & 33.2 & 27.6 & $42.55^{\circ}$ & 598 “ & $\left\{\begin{array}{l}1830-1846 \\
1849-1852\end{array}\right.$ \\
\hline Battle Creek. & 27. & 24.1 & 22.6 & 33.7 & 26.85 & $42.2 \circ$ & $800 \lll$ & $1849-1855$ \\
\hline Ann Arbor... & 25.3 & 23.6 & 21. & 32.7 & 25.65 & $42.15^{\circ}$ & $700 \cdots$ & $1854-1855$ \\
\hline
\end{tabular}

It will be seen that the warmest stations are in most intimate connection with large bodies of water: Fredonia is on Lake Erie, Rochester near Lake Ontario, Auburn near the central New York lake region and possibly within the influence of Lake Ontario, while Utica is farther inland. Similar observations might be made eoncerning the Michigan stations. Temperatures of the coldest days would show much greater differences.

It should be observed that the influence of a body of water is not governed by its proximity, but by elevation of the land and direction of winds. Grand Rapids, Michigan, although about twenty-five miles from Lake Michigan, is greatly influenced by it.

It is evident that if a wind-break stops or deflects a warm wind, it may prove injurious. A still place in the lee of the wind-break may, therefore, be the coldest part of the plantation. So far as the writer is able to learn, this sort of injury from wind-breaks is confined to those regions which are directly influenced by bodies of water. The eastern shore of Lake Michigan has furnished many examples. Most growers 
in that region demand a free cireulation of air from the lakeward, while desiring protection from the east. (Cf. Mr. Cook's letter in Table IV., page 70.) This experience, however, does not argue that wind-breaks should be entirely abolished on the lakeward sides of plantations, but that such breaks should be thin enongh to allow of the passage of wind, while breaking its foree. In such places, a wind-break should be simply a wind-break, not a wind-stop.

The diagrams (Figs. 4 and 5) admirably illustrate

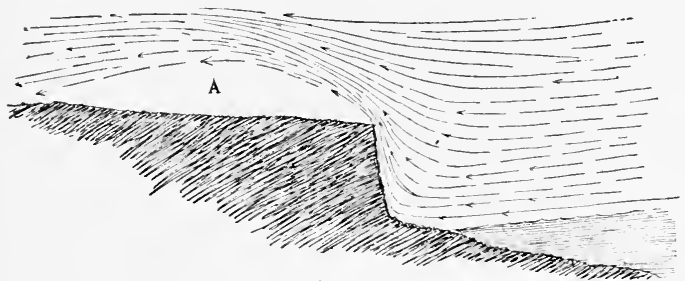

Fig. 4. The deflection of winds over a lake bluff.

these remarks. Fig. 4 is a diagram of a high bank on Lake Michigan. The strong winds from the westward strike the bank and are deflected upward, and strike the surface again at some distance from the eliff, leaving a eomparatively still space at A. Decaying substances on the beach of the lake are often more obnoxious to those living half a mile or more from the lake than to those living near the bank. Fig. 5 is a diagram showing a similar defleetion of wiud and a eomparatively still area (A) by a very dense wind-break. 
The advantages of wind-breaks in lessening windfalls, and in preventing the breaking of trees, do not appear to be sufficiently understood. In sections which are influenced by large bodies of water, or when the fruits grown are sufficiently hardy to endure the most trying winds, these are the chief advantages of shelter belts, and are ample reasons for planting them. The greater facility with which labor can be performed in windy weather, under the protection of a wind-break, is worth consideration.

The injuries sustained through the greater abun-

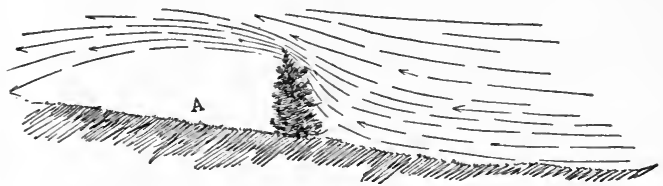

Fig. 5. Deflection of winds by a dense shelter belt.

dance of insects immediately adjoining the windbreak are easily overcome with the modern spraying devices. There are many instances in which the wind-break lessens the vigor of one or two adjoining rows of fruit trees, but such injury appears to occur only where cultivation is poor, or where the windbreak has already obtained a good foot-hold when the fruit is set. The writer has examined a number of excellent plantations in which the rows next the wind-break are as vigorous and productive as any in the orehard. In fact, a number of good observers declare that best fruit and greatest productiveness 
oceur next the wind-break. When the wind-break has been long established, however, it is diffieult to make trees live alongside of it. The better plan is to plant the break with or only shortly before the orchard is planted.

The following from T. G. Yeomans \& Sons, Walworth, Wayne County, New York, who have had extensive and pronounced experiences with wind-breaks, is a judicious statement of the advantages to be derived from shelter belts: "We have been extensively engaged in fruit-culture for over forty years, and now have in bearing about one hundred and thirty aeres of apple orchard, ten acres of dwarf pears, ten of orange quinee, and small fruits. For many years we have experimented with wind-breaks, and now have many artificial shelter belts of various kinds and ages, the olklest having been planted nearly thirty years. We consider wind-breaks to be of the greatest value to fruit enlture, and we are confident that most fruit-growers do not realize their importance. They proteet the trees and plants at all seasons, and prevent windfalls to a great extent. Orchards thus proteeted in this region are more productive, more nniform, and longer lived than others. They render labor among the trees and plants much easier on windy days, and enable men to work in very windy weather, when otherwise it would be impossible. We have always sueeeeded in raising good fruit close to the wind-break. * * * We eonsider land devoted to shelter belts as very profitable investment, even to ordinary farm crops. We should not 
attempt to grow dwarf pears, orange quinces or raspberries, without shelter of some sort."

Position of the wind-break with reference to the fruit plantation.-It appears that a wind-break is desirable wherever the fruit plantation is exposed to strong winds. In order to prevent possible injury from too little circulation of air in certain localities, particular care should be exercised in the construction of the wind-break (ef. next section). The west, southwest, and north winds are the ones which need greatest attention in general. The prevailing winds are the ones which are chiefly to be avoided. This is particularly important in regions where these winds are normally strong, as on the ocean shore. In fact, it is generally impossible to grow successful orchards in full exposure to the ocean.

How to make the wind-break.-From a general study of the subject, it appears that in interior localities dense plantings are advisable, tight hedges being often recommended. This is because the winds, coming off the land, are likely to make the plantation colder. In localities influenced by bodies of water, however, it is evidently better practice to plant a belt simply for the purpose of breaking or checking the force of the warmer winds, still allowing them to pass in their course. Such a belt gives the desired shelter to trees when laden with fruit and ice, and may hold the snow, while danger from comparatively still air is averted. The damage from still air is usually observed in the lee of 


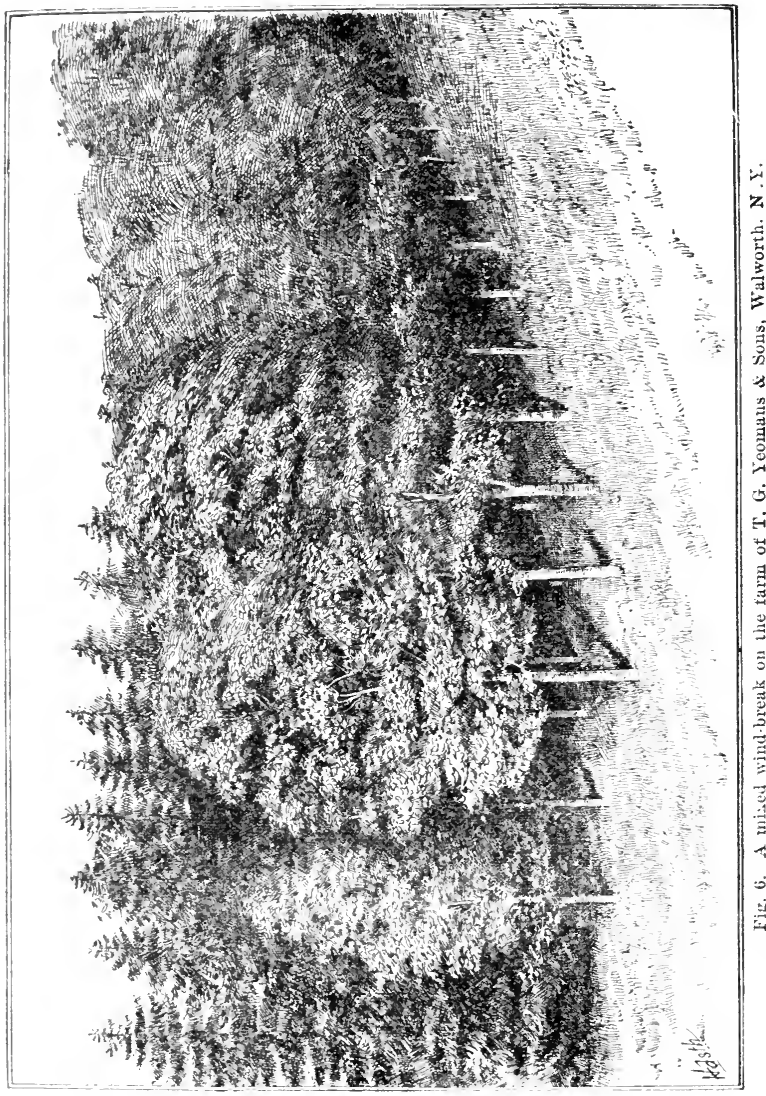


natural forests, and it is in such places that injury is reported by correspondents. The writer has found no indisputable evidence to show that such injury ever accompanies artificial wind-breaks; places where such injury was reported have been visited, but the loss of trees and fruit was plainly due to age of trees or other obvious reasons. Still, it is probable that a hedge-like wind-break may sometimes be the cause of mischief; and such should never be made in any locality until the problems of local atmospheric drainage have been well considered.

The coarser evergreens, planted close together, are therefore advisable for interior places, while deciduous trees, or evergreens somewhat scattered, are often better for the lake regions. In these latter eases, however, the lay of the land is important, for if atmospheric drainage is good there is less danger of injury from tight belts. Lower levels, upon which cold air settles, are therefore more in need of open belts than higher lands. For interior places, a strip of natural forest is the ideal wind-break. In artificial belts, the kind recommended by Messrs. Yeomans, and illustrated in Fig. 6, is undoubtedly one of the best. The illustration shows two rows of maples backing up a row of Norway spruce. "The maples then receive and break the force of the wind, and prevent the spruces from becoming ragged. We never shear the spruces." A Lombardy poplar wind-break alongside a peach orchard is shown in Fig. 7, on the following page. 


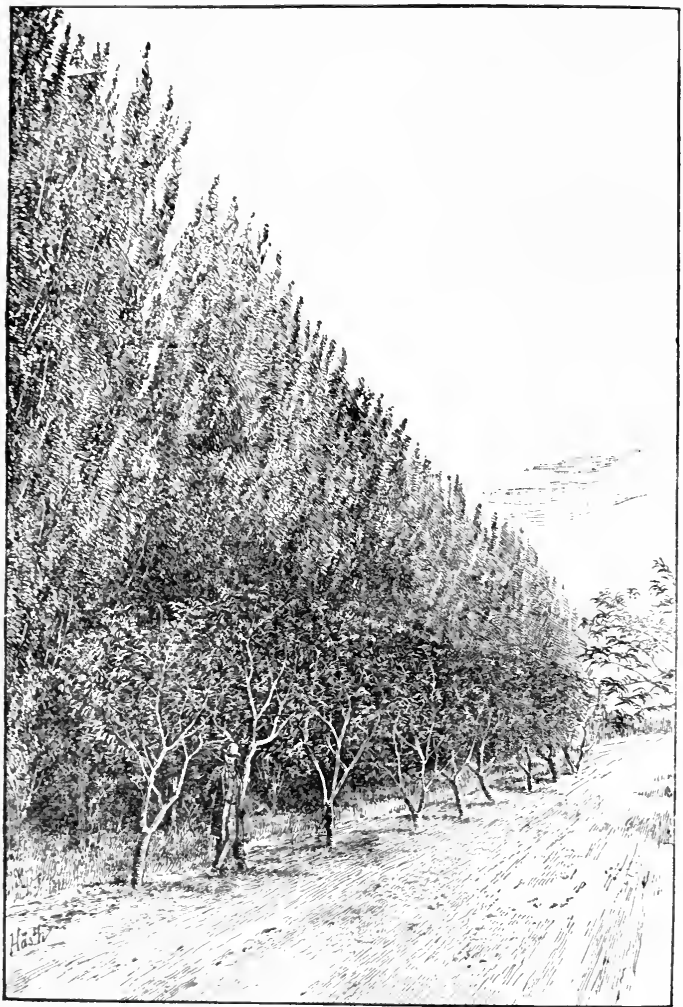

Fig. 7. A Lombarly poplar wind-hreak to protect a yeach orehard, in southwestern Michigan. 
Correspondents in New York and Michigan advise the following trees for shelter belts:

Recommended by

Norway spruce ......25 persons.

Austrian pine ....... 5

Seotch pine........ 3 "

White pine......... 2 "

Native deci'ous trees 2 "c

Lombardy poplar.... 2 "

European lareh..... 1 "
Recommended by

Hemlock spruce..... 1 person.

Arbor vitæ ......... 1 "

Nut-bearing trees .... 1 "

Hard maple........ 1 " "

Elm.............. "

Basswood .......... 1 "

Willows............ 1 "

The gist of the whole matter is to select those kinds of trees which are most thrifty and healthy in the particular locality, and which are least infested by fungi and insects that are also common to fruit plants, and then to study the local conditions carefully to determine how dense or how open the shelter should be. For California, Wickson* recommends species of eucalyptus, pepper or schinus, Monterey cypress, Monterey pine, osage orange, locust and maples. "Quite a number of the larger growing deciduons fruit trees," he continues, "are used to some extent along the exterior lines of orchards for the protection of the inclosure. The fig, the walnut, the chestnut, seedling almonds and apricots, are especially commended for such use."

In Florida it is a common practice to leave strips of the original forest to serve as shelter belts. If this forest is hammock land, and therefore well clothed underneath, the protection of a belt two to four rods wide will be most complete.

* California Fruits, 558. 
The abbage palmetto is often allowed to stand promisuruously through the orange plantation, partly to serve as a protection from winds, partly for shate and ornament, and partly to exert some supposed influence in correcting the acidity of the land. In exposed places, orange-groves are sometimes protected by very tall open fences.

General summary upon wind-breaks.-1. A windbreak may exert great influence upon a fruit plantation.

2 . The benefits derived from wind-breaks are the following : Protection from cold; lessening of evaporation from soil and plants; lessening of windfalls; lessening of liability to mechanical injury of trees; retention of snow and leaves; facilitating of labor; protection of blossoms from serere winds; enabling trees to grow more ereet; lessening of injury from the drying up of small fruits; retention of sand in certain localities; hastening of maturity of fruits in some rases; encouragement of birds ; ormamentation.

3. The injuries sustained from wind-breaks are as follows: Preventing the free cireulation of warm winds, and consequent exposure to cold; injuries from insects and fungous diseases; injuries from the encroatehment of the wind-break itself; increased liability to late spring frosts in rare cases.

a. The injury from cold, still air is usually confined to those localities which are directly influenced by large bodies of water, and which are protected by forest belts. It can be avoided by planting thin belts. 
$b$. The injury from insects can be averted by spraying with arsenical poisons.

$c$. The injury from the encroachment of the wind-break may be averted, in part at least, by good cultivation, and by planting the fruit simultaneously with the belt. So far as practicable, the wind-break should be planted at a distance of six rods or more from the fruit plantation.

4. Wind-breaks are advantageous wherever fruit plantations are exposed to strong winds.

5. As a rule, in localities where atmospheric drainage will not be seriously checked, the windbreak should have a comparatively dense bottom, formed by uudergrowth or low-branching trees.

6. The wind-break should never be dense enough to force the buds on fruit trees in those localities which are subject to late spring frosts, as it may sometimes do when it faces the south and acts like a southern exposure for the plantation. It is evident, therefore, that spruces and other evergreens should be planted sparingly in such localities, and that deciduous trees which leaf out late in spring should be chosen for the wind-break.

7. In interior places, dense or broad belts, of two or more rows of trees, are desirable, while within the influence of large bodies of water narrow belts, comprising but a row or two, are usually preferable.

8. The best trees for wind-breaks in the northeastern states are Norway spruce, and Austrian and Scotch pines, among the evergreens. Among deciduous trees, most of the rapid-growing native species 
are useful. A mixed plantation, with the hardiest and most vigorous decidnous trees on the windward, is probably the ideal artificial shelter belt.*

PROTECTING PLANTATIONS FROM FROST.

Having now considered the relations of location, site and wind-breaks to eold and frost, we may address ourselves to a discussion of the means by which injury from local frosts may be averted, in ease they threaten to oceur. These means are of two types,those which attempt to enable the plant to escape injury from the frosts, and those which attempt to prevent the frost from oceurring. Altogether there are six general means which have been proposed for protecting plants from frost: Mnlehing, covering the plants, adding the vapor of water to the atmosphere, making artificial clouds, causing eurrents of air, and heating the air. $\dagger$

Mulching to enable plants to escape frost.+-It is a general opinion that a mulch or heavy cover placed upon the soil about plants when it is frozen will retard flowering and the maturing of fruit; yet the practice appears to be often unsatisfactory, and there are reasons for supposing that the philosophy of the subject is not commonly understood. The subject is one of increasing importance, for it is essential that

\footnotetext{
* Bull. 48, Neb. Exp. Sta., on wind-breaks, comes to hand as we go to press.

$\dagger A$ seventh eategory may be added,-whitewashing the plants. See Whitten, Bull. 38, Mo. Exp. Sta., and Garden-Making, p. 64.
}

†Consult Bull. 59, Cornell Exp. Sta. 
every means be used to escape late spring frosts. Efforts must also be made to reach the market when there is least competition from other sources, and, in the north, at least, this competition comes chiefly from early products produced in states to the southward. A rehearsal of experiments made to test the efficiency of mulching for these purposes will indicate the nature of the problem.

The tests were made at Ithaca, New York. The ground froze deep in December, and the frost did not leave it until the middle of March. Upon the 28th of February, 1893, the snow being well settled and a foot and more deep in the open fields, heavy mulches of coarse manure and litter from horse stables were placed about apples, almonds, buffalo berries, blackberries, raspberries, currants, gooseberries, grapes, Juneberries, peaches and quinces; and strawberries were mulched later. Observations were also made upon roses which were mulched in the fall for winter protection.

The apples and other tree-fruits comprised trees which were set in the spring of 1889 Half of a large wagon load a gooseberry of mulch was placed about each tree, covering the snow deep for a distance of three feet or more in all directions. The small-fruits were mulched heavily to the middle of the rows, or three and a half to four feet in each direction. A heavy 
wagon load of mulch was suffieient to eover about ten feet of row. On the 29th of March, these mulches were examined, and, although the frost had left the fields fully ten days before, the earth under the rover was still solidly frozen and from six to eight inches of snow persisted. Here, then, was an excellent opportunity to study the effects of a cold soil upon the regetation of plants. On the 13th of April, there was still frost and snow under the gooseberry mulches, and ret both mulched and unmulched plants seemed to be starting alike. It was apparent that the temperature of the soil exerted no influence upon the swelling of the buds, for the buds which projected above the mulch were as forward as those upon untreated plants, while the buds immediately under the muleh, upon the same twig, were wholly dormant. The illustration (Fig. 8, page 93) shows a gooseberry twig upon which this difference is apparent. The twig was covered up to the point indicated by the mark $(A)$. The protruding portion is seen to have pushed its buds forward, except the very tip, where the shoot was winter killed. Shoots of which the tips were caught under the mulch showed perfectly dormant buds at both ends, while the protruding middle portion was as forward as twigs upon unmulched plants. Moreover, the protruding portions of the mulched plants maintained their forwardness, and prodnced leaves, flowers and fruit at the same time as the contiguous plants which were not treated. Crandall currants, Juneberries, roses, grapes, and all the tree fruits, 
behaved similarly throughout the season. The mulcked blackberries, raspberries and Victoria eurrants seemed to be a day or two behind the others in starting, but they very soon caught up, and there was no difference in season of bloom and maturity of fruit.

With the strawberries the case was far different. General Putnam and Oregon Everbearing were mulched March 25, when the ground was completely thawed out. The mulch covered the plants and the entire space between the rows to the depth of three inches. On the 15th of May, this mulch was removed. At this time, the unmulched plants were in full leaf, and were nearly ready to bloom. The plants under the mulch were just starting into leaf, and the growth was weak and bleached. The plants were endeavoring to push themselves through the cover to the light and air. The mulch was forked off the plants, and they gradually assumed a normal color and habit, and bloomed June 1. The bloom was delayed from ten days to two weeks, according to the depth of the covering. The plants did not seem to recover entirely, however, and the fruitage was somewhat lighter than on the normal plants; but it was delayed about a week.

All this is what the botanist would have expected. It is well known that plants store up starchy matters in their bulbs or branches, to be used in the growth of the adjacent parts in early spring. The earliest bloom of spring is supported by this store of nutriment, rather than by food 
freshly appropriated from the soil. This is well illustrated by placing well-matured twigs of apple or willow (or other early-flowering plants) in vases of water in winter, when the buds will burst and flowers will often appear. It was admirably enforced by a simple experiment which we made in conneetion with the foregoing inquiry. On the 15th of February, a branch of a nectarine tree which stood alongside the horticultural laboratory was drawn into the office through a window. This office was maintained at the temperature of a living room. On the 6th of April the buds began to swell, and the young leaves had reached a length of threefourths inch a week later. The leaves finally attained their full size upon this branch before the buds npon the remaining or out-door portion of the plant had begun to swell. This experiment is by no means a novel one, for essentially the same thing has been often accomplished with the vine and other plants; but it must impress upon the reader the fact that much of the bursting vegetation of springtime is supported by a loeal store of mutriment, and is more or less independent of root action.

These various experiments and observations show that a mulch can retard flowers and fruit only when it cover's the top of the plant as well as the soil. If the ground could be kept frozen for a sufficiently long period after vegetation begins, the plant would consume its supply of stored food, and might then be eheeked from inactivity of the root, but this would evidently be at the expense of in- 
jury to the plant; but, in practice, it is fortunately impossible to hold the frost in the soil so long. It is evident, too, that the covering of strawberries and other low plants for the purpose of retarding fruit must be practiced with eaution, for a mulch of sufficient depth to measurably delay vegetation is apt to bleach and injure the young growth, and to lessen the crop. Yet it can sometimes be used to good effect, and fruiting can be delayed a week, perhaps even more. Some skilful strawberry-growers are able to delay fruiting upon small patches as much as two weeks by means of mulches.

We may draw the following conclusions upon the effects of mulching to retard bloom :

1. The early bloom of fruit-plants depends very largely upon the appropriation of food stored in the twigs, and it is more or less independent of root action. This is proved both by direct experiment and by study of the physiology of plants.

2. It must follow, then, that the temperature of the twig or branch must be reduced if its vegetation is to be much retarded; or, in other words, the top of the plant, as well as the soil, must be mulched, and in practice this is possible only with strawberries and other very low plants, or. those which are laid down during winter.

3 There is danger of injuring plants by heavy mulch which is allowed to remain late in spring. If it is desired to retard flowers or fruit by mulching, the practice should not be violent, and the plants should be carefully watched. 
4. Many strawberry-growers are able to delay the ripening of fruit by mulching from two days to two weeks; but a week's delay is usually about the limit of profitable results.

5. Whilst mulching the ground may not retard the period of bloom, and thus enable the plant to escape frost, it is, nevertheless, often useful in proteetion from frost because it holds moisture, and, therefore, tends to raise the dew-point, as explained farther on.

Corering plants for protection.-The discussion of the mulching of strawberries in order to protect them from cold and from frost, as already deseribed, really belongs here. It is, of course, well known that plants may be covered to protect them not only from the winter's cold, but from the incidental frosts of spring. It is not necessary to diseuss the varions means of covering them, but to enter into only sufficient detail to enable the reader to grasp the capabilities of the operation.

Many low-growing plants can be covered with earth for protection. Thus it is a practice in some places to plow a furrow or two over the strawberry rows when a frost is anticipated, Fig trees, and other low or flexible-stemmed plants, are often planted on sloping land, so that they may be bent to the surface and covered when occasion requires. In parts of Russia, and other cold countries, the trees of orehard fruits are often pegged down in a similar manuer.

Blackberries and raspberries are extensively laid 
down in cold climates, and it may be well to relate the method here, for the benefit of those who occupy bleak locations. Late in fall, the bushes are tipped over and covered. Three men are generally employed to perform this labor. One man goes ahead with a long-handled, round-pointed shovel and digs the earth away six inches deep from under the roots. The second man has a six-

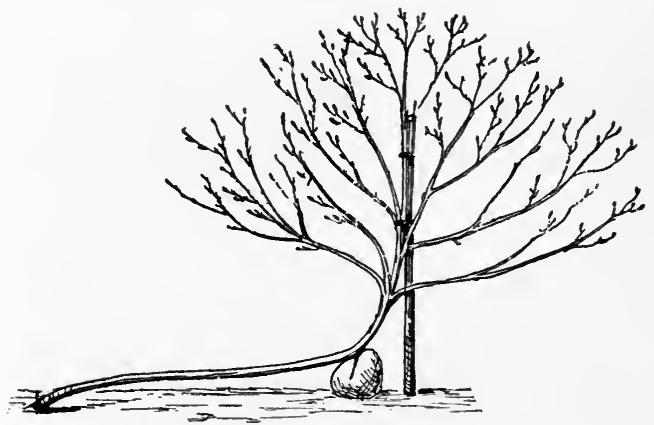

Fig. 9. Peach tree trained for laying down.

tined or four-tined fork which he thrusts against the plant a foot or so above the ground, and by pushing upon the fork and stamping against the roots with the foot, the plant is laid over in the direction from which the earth was removed. The third man now covers the plant with earth or marsh hay. Earth is generally used, and if the variety is a. tender one the whole bush is covered 
two or three inches deep. Hardy varieties may be simply held down by throwing a few shovelfulls of earth on the tops of the canes, thus allowing the snow to fill in amongst the tops. If the grower lives in a locality where he does not fear late spring frosts, the bushes should be raised early in the spring; but if frosts are feared, they may be left under cover until corn-planting time. If the buds become large and are bleached white under cover, they will suffer when exposed to the atmosphere; and one must watch the bushes in spring, and raise them before the buds become soft and white. This method of laying down blackberry plants costs less than $\$ 10$ per acre, and the slight breaking of the roots is no disadvantage. Some growers dig the earth away on both sides of the row, and still others bend over the canes withont any digging. Whatever method is emploved, the operator must be careful not to crack or split the ranes. The method can be varied with different varieties, for some bear stiffer canes than others.

The laying down of orchard trees is little practiced in this country, but it must come to be better understood as the country develops and a greater interest arises in amateur fruit-growing. Fig. 9 (page 99) shows a method of training peach trees for laying down.* The trunk is trained in a horizontal position, and it should be ten feet or more long to allow of its being twisted. The top is trained

*.J. T. Macomber, "Peach-growing in the Cold North," Amer. Garden, xi. 231 . 
fan-shaped and is supported by a stake, and the bend of the trunk rests upon a block of wood. The long, horizontal trunk remains comparatively small and pliable year after year. It should be covered with an inverted board trough at all seasons, to prevent injury from the sun. The flat top is laid upon the ground each winter, by twisting the trunk, and is covered with boards; it is not lifted ununtil all danger of late spring frosts is past.

Experiments along this line have been made in Kansas:* "When the first attempt at their protection was made, the trees [peaches] were three years old from the bud. In the fall of that year, 1887, the block was thinned out by removing some of the trees, leaving the remainder at irregular intervals, the alternate best trees with single, unforked trunks, being left standing wherever they occurred in the rows, with the result of an irregular alternate arrangement, in which the trees stood perhaps from six to ten feet apart. The tops of a number of these trees were prepared for tying-up by the removal of any wide-spreading branches, and by the shortening-in of those remaining. After this pruning, the branches were drawn toward the main stem, held in place by ties of soft material to avoid the barking of the branches, and the entire tree-top thus prepared was surrounded by evergreen branches, mostly those of pine and red cedar, which happened to be at hand throngh certain changes in the ever-

* Bull. 14, Kan. Exp. Sta., Dec., 1890. 
green plantations on the college grounds. Not only were these evergreen branches plaeed ontside to some thiekness, where they were held by cords wrapped around, but the spaces in the interior were filled with them as compactly as possible. To support this heavy mass of material, two or three stakes were driven alongside the tree in position to be wrapped in with the branches. This attempt was followed by results but partially favorable. While the trees that had the advantage of protection showed more bloom than those alongside not so protected, the difference was not sufficiently marked to warrant the conelusion that this method could be made of praetical benefit. It was found to be a matter of diffienlty to retain the evergreen branches closely enough in and about the head of the peach tree to keep out the killing eold. Moreover, covering material of this kind could not be obtained in our state, except by accident, and some substitute must be found. As a cheaper and, it is probable, a better material, we should have made a repetition of the trial with eorn fodder, had we not been led by a stray suggestion to modify the method. "The following fall, 1888, the trees were in good rondition for further trial. The shortening-in of some branches and the thinning-out of others had left abundant fruiting wood, favorably distributed and well covered with fruit-buds. Our plan was now to bend the trees downward, bringing them as near the earth as possible, and keeping them in this position, to be covered by a mass of hay or similar material 
thrown over the tops. To facilitate the bending-down of the tree, the earth was removed on the opposite sides of the trunk, preferably north and south, and on these sides the larger roots were cut off near the base, those on the right and left being allowed to remain as far as possible undisturbed, to keep the tree in unbroken connection with the soil. Now, as the tree-trunk was inclined toward the earth, the lateral roots, by twisting slightly, offered no resistance to the operation. When the tree was sufficiently inclined, forked stakes were driven over the branches into the earth, to keep all in position. The soil was then heaped well over the roots and base of the trunk, to a depth sufficient to protect them thoroughly against drying out, and finally the entire tree was covered with whatever of suitable material was at hand. Not having enough of this covering material upon the grounds, we bought of a neighboring farmer the poor hay in the top and bottom of an old stack at a nominal cost. This final covering was put in place in the last of November. To prevent the scattering of the hay by the wind, we soon after found it expedient to hold it in place by throwing upon the piles a lot of brush, grape prunings, and the trimmings of the orchard.

"Early in the following April (the $2 \mathrm{~d}$ and $3 \mathrm{~d}$ ), when the warm weather began to burst the buds, the covering was removed, the trees raised to an upright position, properly staked and tied, the blooming shoots again shortened-in where necessary, the earth replaced firmly about the roots, the ground leveled, 
and the rubbish removed. The trees were now allowed to make whatever growth the season might afford. The trees laid down were in all varieties found, on uncovering, to be in advance of their unprotected neighbor's, and in several cases the flowerbuds were expanded under the cover, the buds on standing trees being yet unblown. When all were in the best condition for an estimate of the proportion of bloom, a comparison of the trees that had been laid down with others of the same varieties exposed to the winter, showed for the former proportions of full bloom varying from one-third in Ringgold to two-thirds in most varieties, exposed trees of the same showing only here and there scattering blooms. Hale's Early gave on exposed trees a third, and on protected trees three-fourths of a full bloom. Most of the trees set a large number of fruits, and prospects were good for a (rop; but at the time of ripening a peculiar rot attaeked all sorts alike, and of the whole not over a bushel of sound fruit was gathered.

"The third trial, 1889, was conducted in all respects like the second. The trees had by the end of the summer recovered from the rather severe pruning neecssary to bring them to place the previous fall, and were accordingly in good condition for the last attempt. Moreover, the growth of the unpruned side-roots had been such as to put the trees fairly into shape to do well without the roots at front and bark, and when these were again uncovered they were found to be short but fibrous, 
wherefore their amputation to facilitate laying down was no longer needed.

"The result of the last trial, shown in the product of the summer just past, may be summed np briefly in these statements: The trees are now in good, healthy condition. The bearing wood is in a compact head, with no long branches to be broken down by the fruit. The shoots and spurs are, at this writing, eovered with plump fruit-buds. The lateral roots are strong, while those at front and back are no longer an obstacle to the operation of laying down the trees. There was this year a full crop of fruit, and such fine Crawfords, Oldmixons, Smocks, Stumps, Elbertas, Columbias, Bonanzas and Ringgolds were not to be found in any orehard but our own in this locality, though in some favored stations outside the college farm certain seedling trees were in fruit in a limited way. We sold most of the product readily on the spot at the rate of sixty cents per basket for the finest early, and fifty cents for the later fruit, the basket being the ordinary ten-pound grape package.

"The cost of putting down seventy-one trees in the fall, including labor and hay bought, with the expense of replacing them in the spring, amounted to about twenty cents per tree, the labor being paid at the rate of ten cents per hour, and the hay costing two dollars. The average yield of the trees, accounting for fruit gathered and sold, and aliowing by estimate for some stolen, was not far from onehalf bushel each, leaving, at the prices obtained, a 
net return of not far from one and one-half dollars per tree."

Some kinds of fruits may be advantageously protected by covering them with temporary (or even permanent) sereens. This is extensively done in pineapple culture, in which the better varieties are grown under lath or slat sheds, for the purpose of protection from frost, sin and drought. Small or amateur plantations of strawberries, or even of bush-fruits, may be easily covered with lath screens when frost is feared.

Adding rapor of water to the air. - The most serious frosts usually oceur when the air is dry. An abundance of watery vapor in the air probably tends to check the radiation of the earth's heat, and the evaporation of water has a prononnced influence in raising the dew-point. The means of adding vapor to the atmosphere are several: Spraying, flooding and irrigating, mulching and tilling. A thorough spraying of plants with ordinary cold water at nightfall, when a frost is feared, is one of the most efficient means of protection from light frosts. The machinery which is used in spraying for inserts and fungi may be used for this purpose. Strawberries and other low plants may be wet at nightfall by means of a sprinkling cart. Elaborate stand-pipe devices, eonneeting with underground pipes, have been used in California to facilitate the spraying of orehards.* The flooding of fruit-plantations to protect the plants from frost is practi-

* Sor Galloway, Yearbook, U. S. Dept. Agric. 1895, 156. 
cable only in cranberry bogs, and in places where vineyards are arranged to be flooded for the destruction of phylloxera.

The following remarks by Hammon indicate the nature of the problem :*

"In places where irrigation can be used, it will be found of great value in protecting against frost. Let the water be turned on until the soil is thoroughly moistened. The evaporation of the water from the damp soil will tend to raise the dewpoint. Since evaporation takes place near the surface this method is especially valuable in protecting low plants and shrubs, but has also been found very valuable in protecting citrous groves from freezing weather. The irrigating should be done at as early an hour as possible, preferably on the day preceding the night when frost is anticipated, and the ground kept thoroughly wet until danger from frost is passed."

"Moist soil, or localities that can be easily flooded for the purpose of protection, are to be preferred to dry sections of otherwise similar location; for the evaporation of the moisture from the soil, on dry, cold nights, will tend to raise the dew-point of the air and thus diminish the probability of frost.

"The irrigation of the hillsides about a valley in which protection is desired, and the growing

*W. H. Hammon (Forecast offieial United States Weather Burean), in "Frost, How and When to Prevent Injury Thereby;" also pub. in Cal. Frt. Gr., Feb. 8, 1896. 
thereon of plants or trees with a large amount of foliage will, by the evaporation from the soil and verdure, tend to raise the dew-point of the surface air as it flows downward into the valley."

"A modified form of water protection which is valuable in orchards is to spray the trees with water. This plan is probably even more valuable in protecting from freezing citrous fruits and other plants which are not injured until the temperature has fallen several degrees below the freezing point; for, in these cases, the water will tend to freeze before the fruit is injured, and in freezing will make sensible a large amount of heat, thus preventing further cooling of the air. For this method to be successful the spraying must be eontinued until the temperature rises."

Kedzie writes as follows upon the subject:*

"The vapor of water in the air (and elouds also) prevents the escape of heat by radiation from the soil and consequent cooling of the ground during the night. But for the vapor of water in the air, we should have a frost every night in the year." "The old plan of a tub of water under the fruit tree, and a rope reaching from the tub into the branches, may serve a useful purpose. The evaporation from the water in the tub and of the water carried up by capillary action in the rope may spread the protecting folds of the water blanket over the tree. Such appliances, while of some use for a small garden, would be futile for a farm.

* R. C. Kedzie, "Foreeast of Frost." I Lansing, Mich., 1892. 
"If the hoed crops of the farm are cultivated with reference to securing a constant supply of moisture in the upper soil - to draw by capillary action of the soil upon the reservoir of water in the subsoil, and at the same time keep the surface soil in such condition as to prevent the too rapid dissipation of soil moisture-the fields may be saved from frost by a covering as impalpable as air but as effectual as eider-down. Here is a conservatism of highest importance for both farmer and fruit-grower.

"On the night of Sept. 16, 1868, the Indian corn in Michigan was almost entirely killed by frost, only a few fields along the banks of rivers or the borders of lakes being spared. In these fields the corn-stalks the next morning were dripping with dew. The evaporation from river or lake during this dry time (only one-eighth inch of rain in two weeks) had moistened the air in their vicinity and stayed off the frost. Away from bodies of water the air was very dry and the dew-point low. At the Agricultural College the temperature in the open air at 2 P. M. Sept. 16, was $54^{\circ} \mathrm{F}$., the wet bulb marked $44^{\circ}$, and the temperature of dew-point was $31^{\circ}$ F. During the night the temperature sank to $24^{\circ} \mathrm{F}$. and a 'black frost' was the result. If the air over the whole state had been as moist as it was along those rivers and lakes, a heavy dew. would have fallen everywhere, and the corn crop spared.

"This immunity from frost afforded by a moist 
atmosphere is a matter of great importance. I once read in a newspaper of the experience of a farmer who feared a frost on his growing corn, and who cultivated the field, stirring up a moister soil, and thus promoting evaporation, with this result, a heary dew and a rescued crop, while neighboring fields of corn were eut by frost.

"Ten years ago some beantiful beds of colens were near my house. Early in October there were threatenings of frost. Every evening the beds were thoroughly wet down with cold water, and the tender coleus plants eseaped frost while other plants near by were killed. At this time I found my neighbor one evening putting blankets over his grape vine to save the fruit from frost. I advised him to take away his woolen blankets and put on the water blanket by a thorough drenehing with water. This was done and the grapes were saved.

"This use of water to guard tender plants from frost has frequently been used at the college, and generally with good results. Strawberries and grapes in blossom may be saved in this way and with little tronble, if a good supply of water and a sprinkling hose are available. The quiekwitted farmer or gardener will find many ways of using water for this purpose. With irrigation, we might defy frost during the growing season."

A systematic plan for evaporating water in orange groves in (alifornia, in frosty weather, has been proposed by Finkle.* It is estimated that

* California Fruit-grower, Feb, 8 and 29, 1896. 
efficient appliances for evaporating water could be secured for about $\$ 15$ an acre for the first cost. "The amount of water required to raise the temperature in the space immediately surrounding a tenacre tract would be about 500 gallons. This I have demonstrated by a very complete mathematical calculation based on experiments, but I have concluded that it would require about four or five attempts during a night, in order to supply the heat radiating into space, which would make the water required to be spent for a ten-acre grove, about 2,500 gallons. * * * * The fuel required is equally certain and capable of calculation, and would be about one barrel of oil, costing in Los Angeles 50 cents."

The making of smudges.-Frosts occur on clear nights. This is because the earth's heat radiates quickly into space. When clouds or fogs are present, this radiation is checked. It is possible, in many cases, to supply a blanket of smoke to check radiation; and if this cover also contains much vapor of water, its efficiency will thereby be greatly increased.

The use of smoke or smudges to protect plants from frost is an old practice. It is necessary, in order to secure the greatest protection, that the smudge be dense and uniform, and especially that it be maintained until all danger of frost is past. The best results are nearly always secured on level lands, where the smoke will not drain away, and where there are no higher lands from which the 
coll air may settle. The best smudges are usually made by burning some tar-like substance. In any case, a smouldering fire is much better than a blaze. The fire should burn slowly, and attendants should keep the smudge going all night. Wet leaves, manure, saw-dust, brush, grass, crude oil, and a variety of materials are in nse for smudges. Some grape-growers cut the trimmings into short lengths and pile them in the vineyard, expecting to use them if frost should threaten. If frost does not oceur, the piles are burned before tillage is begim. Crude petroleum stored in barrel-like tanks or receptacles is sometimes eonducted through the plantation in pipes, and kettles are filled (and ignited) at intervals. Galloway* says that a mixture of one part gas-tar and two, parts saw-dust makes an exeellent material for a smudge.

Hammon writes as follows upon the nse of smudges: "One method of diminishing radiation which is of considerable value, especially in a level country, is the obseuring of the sky by means of the smoke of smudge fires. This method has been used with suecess in the level wheat fields of the Dakotas and Manitoba, and shonld be of about equal value in the broad interior valleys of California. It is not so snceessful in the narrow valleys of a hilly country, for while it retards the radiation of heat in the valley, the smoke bank is asually of low elevation, and radiation proceeds un-

* Year Book, I. S. Dept. Agr., 1895, 155. 
interruptedly from the hillsides, whence the cooled air flows down into the valley underneath the smoke and chills the plants. Damp straw, tar, turpentine, old hay, anything that will result in the greatest amount of smoke, will serve as fuel for these fires. Have the fuel on the ground in advance, and start the fires while the temperature is several degrees above the danger point.

" It is believed that decidedly better results will be attained if damp fuel is used, or if the fire be sprayed with water, for this will add vapor to the air which, in condensing, will assist in checking radiation by obscuring the sky with fog or cloud, and at the same time the dew-point will be raised to the temperature of the air. This plan should result in absolutely preventing injury if the temperature be much above the danger point, for the condensation of the vapor will continue to distribute heat throughout the space occupied by the mist. In the case of smudge fires, the fire warms and expands the air near it, eausing it to rise. This establishes an upward current of warm air from the fire, which conducts the heat of the fire upward and beyond the space needing protection, and cool air flows in from the sides to take its place. Thus the heat of the fire has but little effect in diminishing the intensity of the frost, almost the entire protection being gained by the blanket of smoke produced. By spraying the fire, on the other hand, a large portion of the heat of the fire is consumed in evaporating the water which, rising from the 
fire, is quickly condensed as it eomes in contact with the surrounding air. The heat of condensation thus becomes manifest in the lower air. The heat of the fire is thus in a measure trapped and distributed throughont the lower stratum of the air, and greatly aids in protecting the plants. Every quart of water thus evaporated and again condensed in the surrounding air would be sufficient to raise the temperature ten degrees throughout a space eighty feet square and deep."

Smudges have long been used in the vineyards of parts of Europe. A sketch of some of the practices may add to the interest of this diseussion.* "Protection from frost is often secured by the use of snudges, namely, piles or bundles of such stuff as will produce a great smoke while burning. They are plaeed around the field and lighted at the approach of frost, and the smoke which arises from trees hanging over the fields, will, after the manner of clouds, tend to keep the escaping heat near the earth. Pliny is said to have reeommended the practice, and as early as the sixteenth century it was advised by the great Freneh agrieulturist, Olivier de Serres, who wrote: 'Frost is repelled from the vine if, foreseeing it, you produce in various parts of your vineyard thiek smokes by means of wet straw or half-rotten manures. These sunder the air and dissolve the muisance. $* * * * *$ * Prepare them in good season by building here and there in your fields little piles of the above mentioned matters,

* Prepared by my student, W. S. Andrews, B. A. 
which shall be lighted without delay whenever necessary.' The practice was obligatory in at least one part of Germany at the end of the last century. In Mr. 'Héguilus' pamphlet* is quoted a set of regulations, issued in the Bailiwick of Pforzheim (Grand Duchy of Baden) in 1796, which provides that the inhabitants of the communes shall be divided into companies of twelve or eighteen men, under a chief, to operate in districts assigned them by an official inspector, and provides for a system of night watchmen, whose duty it was to give warning of the necessity for lighting the fires. 'Whoever of the inhabitants,' Article VII. of these regulations reads, 'shall refuse to obey, shall be prosecuted before the bailiff and receive exemplary punishment.' Boussingault found the custom among the Indians of Peru, who inherited it from the pre-Spanish civilization.

"Various substitutes for the bundles of straw, and such primitive smudges, have been proposed, and a number of patented eompositions are on the French market. Mr. A. Lippens, of Ghent, in a letter, describes several of them. He writes:

"'Generally they' [i. e., the French vine-growers] 'use three bundles of small fagots, in which they insert half-dried hay and wet straw. A line of about fifty suffices for a hundred acres.' The cost is about ten cents an acre. 'More enlightened vine-growers use the heavy oils of coal gas from

*Procédé Héguilus, "La Vigne et les gelées printanières." Lodève (Hérault), 1891. 
which the pitch has been taken. About four-fifths of a quart is placed in a flat iron-ware dish. Ten of these will protert a vineyard of one hundred acres; twenty, one of four hundred acres. The dishes are to be set eloser together at the two ends of the line than in the middle, and a supply of oil must be held ready in reserve in case that, on account of wind 'or of great rlearness at sunrise, another firing should be found necessary.'

"M. Lestout, of Bordeaux, has an invention, as described in his pamphlet, as follows: 'It consists of little cubical boxes, twenty centimeters (a little less than eight inches) square, weighing seven kilos (fifteen pounds four ounces), and costing about serenty-five centimes (fifteen cents) apiece. These are placed around the ficld to be protected at a distance of ten meters (thirty-two feet ten inches) apart, and are easily ignited from a torch. The fire emits a black smoke, which can be rendered more dense by pouring water upon the smudges. After awhile, the columns of smoke fuse into a thick cloud, which settles upon the field, and elevates the temperature by two or three degrees. The fires can be instantly put out by an extinguisher.' M. Lestout declares that three hundred smudges, costing two hundred and twenty-five franes (forty-five dollars), will protect a vineyard three thousand meters square-i.e., one containing nine hundred hectares (about two thousand two hundred acres)-namely, at a eost of twenty-five centimes (five cents) per two and onehalf acres. 
"The system of Lagrolet is said to give a very dense, heavy and persistent cloud. The composition is delivered in barrels, the contents of which are in a solid mass, which must be broken up into pieces. Three of these are leaned together like a tripod, in little hollows in the ground, about fifteen yards apart.

"In the Audibert system, the smudges are made by a mixture of tar, creosote and sawdust-easily made and easy to use. There is a system of Tanzin, and others, the details of which it is not necessary now to discuss.

"Lestout advertises that he is able to furnish a system of devices by which warning is given of approaching frost, or by which the smudges can be fired automatically, when the mercury descends to a certain degree. Héguilus has also invented a system of signals and lighters. It is not necessary to dwell upon either of these, further than to remark in passing that a system of automatic lighting will not fulfill its full purpose unless it is so arranged that it will light the fires on the side of the field from which the air is moving. Otherwise one may have the satisfaction of protecting his neighbor's vineyard and not his own. To secure the maximum protection, the proprietors should join in a common effort to protect a whole district at once, as Lestout recommends; and this, it appears from his pamphlet, is being done in France. He gives the statutes of a syndicate formed in 1890 by one hundred and fifteen proprietors in the district of Moulis, Médoc-which make pretty complete pro- 
vision for joint artion - and quotes a letter from their treasurer, in which it is stated that the cost of guaranteeing two million vines for a year was one and a quarter francs (twenty-five cents) per thousand vines. He gives a letter from another syndicate of sixty proprietors at Sanssac, in the Médoc, deseribing a successful attempt to keep the frost from their vines on April 27, 1888. The wires attaching the vines were eoated with ice. It was decided to light the smudges at two o'clock in the morning, when one hundred and thirty were lighted, placed at a distance apart of twelve meters (a little under forty feet), thus extending along a line one thousand five hundred and fifty meters (not quite a mile) long. The report states that not only the vineyards, but everything that frost ordinarily destroys, fields of clover, potatoes, peas, everything, in fact, covered by the cloud, from the line of sumdges extending back to a depth of three thousand meters (say two and three-fourth miles), covering a surface of five hundred and fifty hectares (one thousand three hundred and seventy-five acres), was saved, while the fields not covered by the clond suffered from the effects of the frost on that same day. The one hundred and thirty smudges were only twothirds burnt, and the cost was estimated at thirteen centimes (less than three cents) a hectare (two and one-half acres). Some of Lestout's correspondents express the hope that a law will be passed providing that when two-thirds of the proprietors of a district elect to form a syndicate, they will be 
able to assess their pro-rata share upon such inhabitants of the districts as refuse to join, and that these assessments may be collected by the taxgatherer, a provision which it would be easier to introduce and enforce in France, perhaps, than in this country." Fig. 10 is an illustration of the protection of a vineyard, from Lestout.*

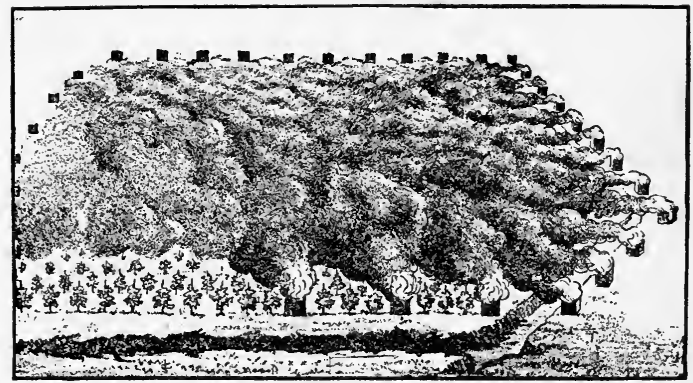

Fig. 10. Smudge over a French vineyard.

Making currents of air. - Since frosts oceur on still nights, it is sometimes possible to prevent. them by keeping the air in motion, thereby mixing the air and preventing any part of it from lying on the plant until it shall have become frost-cold by loss of radiated heat. In small areas, as in choice gardens, it is often feasible to employ a man at night to pass back and forth waving a large

*The Lestout system has been used at Cornell with satisfaction. 
fan. A windmill may sometimes be set in motion by water-power or other means.

Heating the air.-It is sometimes possible to directly heat the air by means of large fires, although such practice does not seem to have generally met with encouraging results. In the combined smoke and vapor smulges which have been commended by Hammon (page 112), the heat of the fire may add something to the effieieney of the protection. The strong currents of air which are set up by heavy fires seldom aid in the protection of the plantation. Yet there are cases in whieh hot fires have saved trees over eonsiderable areas from heavy frosts and even from freezes. One of the best experiences in this direetion is reported from Florida by Davies.* In the freeze of February, 1895, he was able to raise the temperature in his grove from 18 degrees to 33 degrees by means of fires. "On the north and west sides of your grove have what are ealled conflagrations, big fires, that will send billows of heat rolling between and over your tree tops; and all through your groves, at short distances, have small fires to help on the good result." Mr. Davies recommends that orange growers "get ready, and keep ready all the time, for the freeze. Onee it has eome, there will be no time for gathering materials for fire. Your fuel must be on hand, and plenty of it." It is then necessary to keep the fires burning vigorously until the cold spell has passed. H. R. Ste-

*D. O. Davies, "Protecting Orange Groves from Cold," Fla. State Hort. Soc. $1896,2 x$. 
veus, on the same occasion, reports success in saving orange trees from cold by burning rosin, securing both heat and smoke. He makes cones six inches high and six wide of common hardware paper which has received a coat of paint. These cones are filled with cheap rosin and set near the trees. A little of the rosin is pulverized on top, and it is then set on fire from a bit of oiled waste which is dropped on it. Six pounds of rosin burn about an hour.

THE PREDICTION OF FROST.

In considering the means of predicting frost, it is first of all important that the student should obtain a clear idea of the usual or average dates of the opening and elosing of the seasons of his locality. Records made by himself upon his own farm from year to year are invaluable. He may derive very much help, also, from the records of meteorological bureaus. A general tabulation of spring and fall seasons (see pages 123 and 124) may be suggestive in this connection :*

"The data for the accompanying tabulation of the killing frosts of the region east of the Rocky Mountains was compiled from the bulletins and annual reports of the United States Weather Bureau. The table is divided into dates for spring and fall, and these in turn into earliest, latest, and average

* Mlade by Alexander D. MacGillivray, Assistant in Entomology, Cornell University. 
dates. By 'earliest' is not meant the first frost in the spring, but the earliest date at which the season has opened, while when applied to the fall it is the first actual occurrence of a frost. By 'latest' is meant the last occurrence of a killing frost in the spring, and in the fall the latest date at which the season has closed. The average date is in most cases the mean of average dates given by the Weather Bureau.

"The states have been grouped into three regions, the states of the coast plain, the states of the Ohio River basin and its adjunets, and the states of the Missouri River and its adjuncts. The first thought in separating the states into these regions was that they represented distinet faunal regions, and that they probably represented distinct elimatal regions. This has been sustained in most part. The most marked cases are eastern New York, or the Hudson Valley, and western New York, the former belonging to the coast states and the latter to the Ohio valley states. There is a difference of eleven days in the spring on earliest dates, twelve days on latest, and two days on average; Pennsylvania, which falls in the same category, in the spring, fifty-four days on earliest, eleven days on latest, and twenty days on average dates. In the other regions the difference is not so marked, and ret there is some difference in all cases.

"This tabulation is of interest in showing the earliest and latest dates at which the seasons have opened, for some of the data is based on records 
Tabulation of Seasonal Changes, with Special Reference to Killing Frosts.

\begin{tabular}{|c|c|c|c|c|c|c|}
\hline \multirow{2}{*}{ oAst States. } & \multicolumn{3}{|c|}{ SPRING. } & \multicolumn{3}{|c|}{ FAll. } \\
\hline & Earliest. & atest. & Average. & Earliest. & Latest. & \\
\hline & Mar. 24 & June 19 & April 30 & Sept. 4 & Nov. 2 & Sept. \\
\hline New Hampshire. & April 19 & June 9 & May 6 & Aug. 7 & Oet. 30 & Oet. \\
\hline & April 8 & June 3 & May 10 & Aug. 5 & Nov. 16 & Sept. 2 \\
\hline Massachusetts... & Mar. 26 & May 28 & April 20 & Aug. 8 & Nov. 23 & Sept. 1 \\
\hline & Mar. 8 & May 7 & Mar. 31 & Oet. 3 & Dec. 28 & Nov. \\
\hline & Mar. 3 & May 30 & April 28 & Sept. 10 & Nov. 16 & Oet. \\
\hline E. New York.... & Mar. 15 & May 27 & April 23 & Oet. 11 & Nov. 18 & Oet. 2 \\
\hline ew Jerse & Feb. 27 & May 21 & April 13 & Sept. 10 & Nov. 21 & Oct. \\
\hline & Mar. 2 & May 22 & April 5 & & Nov. 6 & Oet. \\
\hline & Mar. 1 & May 9 & April 9 & Sept. 10 & Nov. 14 & Oet. \\
\hline & Mar. 19 & April 12 & April 8 & Oet. 23 & Oet. 31 & Oet. 2 \\
\hline & Feb. 5 & May 17 & April 11 & Aug. 26 & Dec. 10 & Oet. 1 \\
\hline North Carol & Jan. 3 & May 24 & April 5 & Sept. 9 & Dec. 29 & Oet. 1 \\
\hline South Carolina.. & Jan. 4 & May 8 & Feb. 23 & Oet. 15 & Dec. 15 & Oet. 2 \\
\hline orgia. & Feb. 2 & April 16 & Mar. 16 & Oct. 7 & Dec. 10 & Nov. \\
\hline & Dee. 7 & April 7 & $\begin{array}{l}\text { Jan. } 18 \\
\text { Mar. } 22\end{array}$ & Oct. 31 & Feb. 6 & $\begin{array}{l}\text { Nov. } 7 \\
\text { Dec. } 24\end{array}$ \\
\hline & Dee. 27 & April 25 & Mar. 6 & Oct. 12 & Dec. 26 & Oet. 28 \\
\hline & Jan. 16 & April 10 & Feb. 23 & Oet. 8 & Dec. 27 & Oet. 3 \\
\hline & Jan. 12 & Mar. 31 & Feb. 25 & Sept. 21 & Dec. 29 & Dec. \\
\hline & Dec. 16 & April 13 & $\begin{array}{l}\text { Jan. } 21 \\
\text { Mar. } 25\end{array}$ & Sept. 12 & Dec. 27 & Oet. 1 \\
\hline
\end{tabular}




\section{The Principles of Fruit-grouing.}

Tabulation of Seasonal Changes, with Special Reference to Killing Frosts.

()HIO VALLEY

STATES.
SPRING.

Earliest. Latest. Average. Earliest. Latest.

W. New York... Nar. 26 June 8 April 25 Aug. 8 Nov. 21 Sept. 20

Michigan ....... Mar. 2 June 29 May 5 Aug. 2 Oet. 29 Sept. 18

Wisconsin...... April 7 June 12 May 1 Aug. 22 Nov. 13 Sept. 25

Pennsylrania... May 26 June 4 April 25 Aug. 30 Nov. 14 Sept. 28

Ohio .......... Feb. 24 June 12 April 20 Sept. 2 Nov. 15 Sept. 30

Indiana......... Mar. 23 May 28 April 12 Sept. 14 Dec. 24 Oct. 15

Illinois.......... Feb. 28 June 1 April 15 Aug. 2 Nor. 28 Sept. 30

West Virginia... April 1 May 17 April 20 Sept. 22 Nov. 22 Oet. 25

Kentucky........ Mar. 10 May 30 April $\tau$, Sept. 24 Nov. 20 Oet. 15

Tennessee...... Jan. 25 May 15 April 1 Sept. 14 Nov. 29 Oct. 15 MISSOLR1 VAL-

Ley States.

Minnesota...... April 6 June 8 April 23 Aug. 4 Oet. 21 Sept. 29

Dakota......... Mar. 15 June 30 May 15 Aug. 4 Oct. 28 Sept. 10

Iowa.......... Mar. 4 June 2 April 20 Aug. 8 Oct. 28 Sept. 20

Nebraska....... Mar. 28 June 7 April 20 Ang. 30 Nov. 9 Oct. 10

Missouri....... Feb. 27 May 26 April 15 Sept. 2 Nov. 19 Oct. 9

Kansas......... Mar. 16 May 22 April 12 Sept. 6 Nov. 9 Oet. 5

Colorado........ Mar. 29 June 28 May 2 Aug. 7 Oet. 26 Sept. 5

Arkansas....... Feb. 22 April 28 Mar. 27 Oet. 6 Dee. 4 Oct. 27

Indian Territory. Feb. 5 May 23 Mar. 22 Sept. 30 Dec. 7 Oct. 20 
of fifty years or more; in showing the effects of adjacent bodies of water; in the effects of topography, and in situation.

"The effect of topography is shown well in the cases already cited, eastern and western New York and Pennsylvania. It is equally true of Virginia and West Virginia, and North Carolina and Tennessee. The effect of situation is shown markedly in the ease of Maine, which is north of New Hampshire and Vermont, and yet earlier. Georgia's season opens twenty-one days later than South Carolina's, and ten days later than Alabama's, while North Carolina is ten days later."

The liability of any particular locality to injury from late spring or early fall frosts is capable of being expressed in eharts or by other graphic means. Very good records of the habitual frostiness of any place could be made by an army of careful growers who had neither a barometer nor a thermometer. Let us suppose, for instance, that the peach-growers of a certain geographical area were to make observations for a number of years upon the relative synchronisms of late frosts and blooming-time, a subject which is of the most vital importance to every grower of the tender fruits. The tabulation of these observations would enable us to construct two series of eurves, which would indicate at a glance the comparative safety of any station for the cultivation of the given erop. We will suppose that observations have been taken for a number of years by various persons at seventeen 


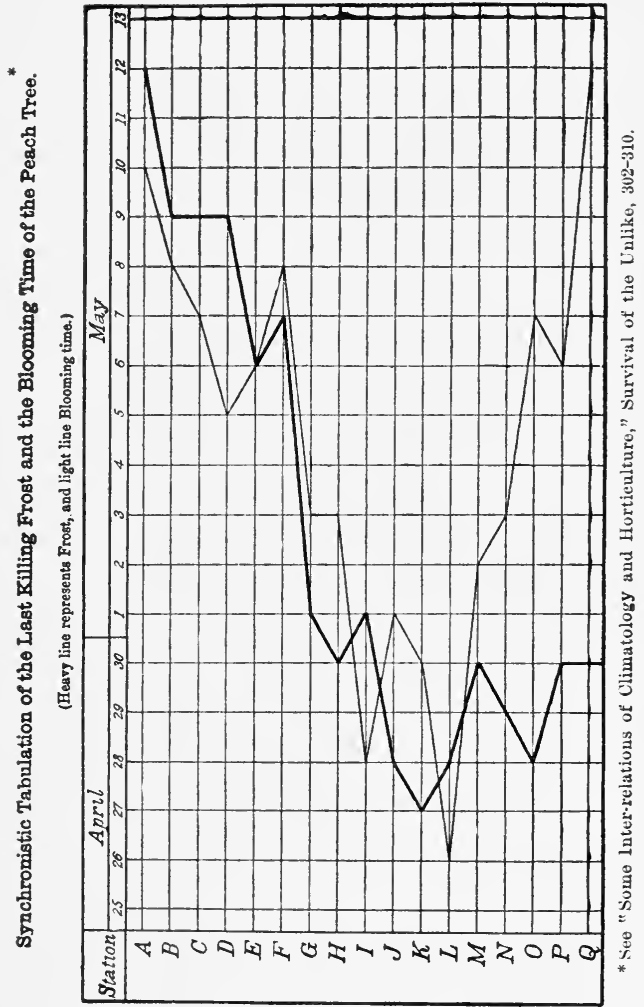


closely connected stations, represented by the letters in the margin of the plate (page 126). One curve represents the date of the last killing frost, and the other the date of the opening of the peach flowers. Wherever the frost line lies beyond the bloom line, as in the first five stations, peach-growing is impossible. When it lies at the left, peachgrowing is possible, and the industry is safe in proportion as the two lines diverge. At the stations $I, K$, and $O$ peach-growing may be considered to be far beyond danger of late frosts. These tabulations would be valuable, of course, in proportion as they include a minute record of every farm in the given territory; but even a somewhat superficial series of observations would possess great value if accurately made, as indicating the probable influence of local climate upon the given industry. If lines tend to converge, or if the frost line crosses beyond the bloom line, there is indication, at least, that safe peach lands are few in those localities. The information which these records ask could be well ascertained from observations upon a few peach trees here and there long before any general experiment of cultivation had been tried.

This method of study is a part of the science of phenology, or that science which treats of the periodical phenomena of animals and plants, as the migrations and nesting of birds, awakening of the frogs, and the dates of blooming and leafing of plants. Such records are more accurate measures of seasonal climates than instrumental measurements 
are. Some day the country will have charts of isophenal lines as well as of its isotherms.

Local studies of this type must eventually come to be an important province of meteorological bureaus. Every state must ultimately be completely charted not only in respect to liability to frosts, but to other incidents of local climate and weather.

The most reliable prediction of frost is given by readings from the wet-and dry-bulb thermoneter, which measures the moisture in the air. Kedzie gives the following description of this thermoneter:* "The sling psychrometer is a formidable name. but a simple instrument. It consists essentially of two thermometers, the bulb of one being left naked and kept dry, the bulb of the other being covered with a thin layer of eloth which is kept wet ('wet-bulb') during the time of an observation. By plaeing these 'dry-bulb' and 'wet-bulb' thermometers side by' side and comparing their readings, we may determine the amonnt of cold produced by evaporation, and thus measure the relative dryness of the air. If there is no evaporation the two thermometers will show the same temperature, but any evaporation will produce cold, and the more rapid the evaporation the greater the reduction of temperature. The drier the air the more rapid the evaporation, and the greater the cold raused by evaporation. The psyehrometer, or the 'wet- and dry-bulb thermometer,' affords the means for determining the amount of moisture in the air,

\footnotetext{
* See also Horticulturist's Rule-Book, 4th ed., 222.
} 
and the temperature of complete saturation or dewpoint, by measuring the reduction of temperature by evaporation.

"A sling psychrometer can easily be made, as follows: For the frame, take a board eighteen inches long, two inches wide, and one-half inch thick, with a hole bored in one end to hang the apparatus on a nail when not in use. Get two all-glass thermometers with cylindrical bulbs, and the degrees Fahrenheit engraved on the stem. Cover the bulb of one thermometer with a thin piece of cotton eloth, fastening it securely by a thread. When this cloth covering is wet with water and exposed to evaporation in the air, it constitutes the 'wet-bulb thermometer'; the other thermometer has no covering on its bulb, is not wet at any time, and constitutes the 'dry-bulb thermometer'.

"Securely lash the thermometers on opposite edges of the narrow board, leaving the graduations on them plainly in sight, and the bulbs extending a short distance below the end of the board. To use the instrument, wet the cloth-covered bulb with water, leaving the other bulb dry, and then swing the apparatus freely through the air for three to five minutes, or until the wet-bulb thermometer ceases to fall in temperature, and then read the temperature of each thermometer. Unless the air is saturated with moisture the wet-bulb will always show a lower temperature than the dry-bulb. Subtract the degrees of wet-bulb from those of the dry-bulb, and the remainder will show the degrees 
of cold produced by evaporation. Suppose the dry bulb marks $65^{\circ} \mathrm{F}$., and the wet bulb $56^{\circ}$, then

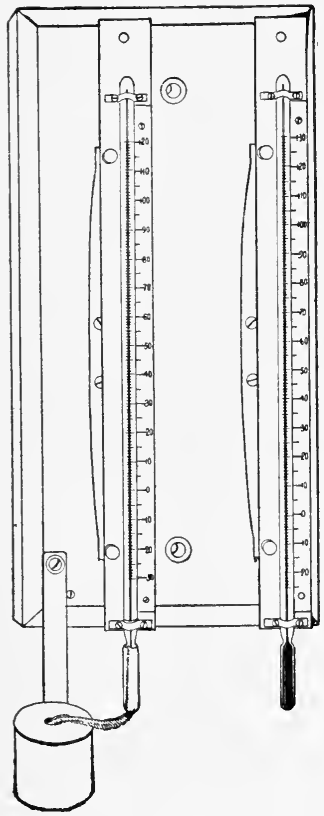

I'ig. 11. One form of wet-and dry. bulb thermometer. $(6 .)^{\circ}-56^{\circ}=9^{\circ}$, or the cold produced by evaporation. This swinging and reading of the prschrometer are done in the shade in the open air when the temperature of dew-point is sought; it should be done rapidly and the thermometers read promptly The dry-bulb gives the temperature of the open air, and dew-point is determined by reference to tabulated figures." A common form of psychrometer is shown in Fig. 11, but inasmuch as this has a cup of water connected with the wet-bulb, it is not so handy for whirling. Such an instrument may be fanned instead of whirled.

Hammon gives the following directions and figures for determining the dew-point : "To obtain the dew-point from the wet-and dry-bulb hygrometer or psyehrometer, moisten the musliu on the 
wet-bulb and then whirl or fan the instrument, when the temperature will fall. Continue the ventilation until the wet-bulb thermometer ceases to fall, when the two thermometers should be read. Subtract the reading of the wet-bulb thermometer from that of the dry. Find this difference in the column at the left of the table. The dew-point will then be found at the intersection of the line opposite this difference and the column which is headed by the number nearest the air temperature (dry-bulb reading). Examples are given below:

"Dry-bulb thermometer........................ 55 $5^{\circ}$

Wet-bulb thermometer....................... $44^{\circ}$

Difference................................ $11^{\circ}$

Dew-point from table......................... $30^{\circ}$ "

The dew-point is the temperature at which the deposition of dew begins. Frost is formed when the dew-point and freezing-point coincide (that is, at $32^{\circ}$ ). The nearer the dew-point approaches the freezing-point at nightfall, the greater is the danger of frost during the night. When the dew-point is $10^{\circ}$ above freezing-point at nightfall $\left(42^{\circ}\right)$, there is little danger of frost; but when it is less than this, frost may be expected.

"DEW-POINT TABLE.

Difference of reading of dry and wet bulbs.

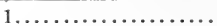

$2 \ldots \ldots \ldots \ldots \ldots \ldots \ldots$

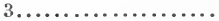

$4 \ldots \ldots \ldots \ldots \ldots, \ldots, \ldots$

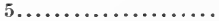

$6 \ldots \ldots \ldots \ldots \ldots \ldots \ldots$

$7 \ldots \ldots \ldots \ldots \ldots \ldots . . .6$.

$8, \ldots \ldots \ldots \ldots \ldots \ldots, \ldots$

$9 . \ldots \ldots \ldots \ldots \ldots \ldots . .6$.

$10 \ldots \ldots \ldots \ldots \ldots \ldots \ldots$

$11 . . \ldots \ldots \ldots \ldots \ldots, \ldots$

12

13

14

15
Temperature of Air - Fahrenheit.

\begin{tabular}{|c|c|c|c|c|c|c|c|c|c|c|c|}
\hline $15^{\circ}$ & $20^{\circ}$ & $25^{\circ}$ & $30^{\circ}$ & $35^{\circ}$ & $40^{\circ}$ & $45^{\circ}$ & $50^{\circ}$ & $55^{\circ}$ & $60^{\circ}$ & $65^{\circ}$ & $70^{\circ}$ \\
\hline $\begin{array}{l}1 \\
6\end{array}$ & $\begin{array}{r}16 \\
12 \\
7 \\
1\end{array}$ & $\begin{array}{r}22 \\
18 \\
14 \\
10 \\
4\end{array}$ & $\begin{array}{r}27 \\
24 \\
21 \\
17 \\
13 \\
7 \\
1\end{array}$ & $\begin{array}{r}32 \\
30 \\
27 \\
24 \\
20 \\
16 \\
11 \\
5\end{array}$ & $\begin{array}{r}38 \\
35 \\
33 \\
30 \\
27 \\
24 \\
20 \\
16 \\
11 \\
4\end{array}$ & $\begin{array}{r}43 \\
41 \\
39 \\
36 \\
33 \\
30 \\
27 \\
24 \\
20 \\
16 \\
11 \\
4\end{array}$ & $\begin{array}{r}48 \\
46 \\
44 \\
42 \\
40 \\
37 \\
34 \\
31 \\
28 \\
25 \\
21 \\
17 \\
11 \\
5\end{array}$ & $\begin{array}{l}53 \\
52 \\
50 \\
48 \\
46 \\
43 \\
41 \\
39 \\
36 \\
33 \\
30 \\
27 \\
23 \\
18 \\
12\end{array}$ & $\begin{array}{l}58 \\
57 \\
55 \\
53 \\
51 \\
49 \\
47 \\
45 \\
43 \\
40 \\
38 \\
35 \\
32 \\
28 \\
24\end{array}$ & $\begin{array}{l}63 \\
62 \\
60 \\
59 \\
57 \\
55 \\
53 \\
51 \\
49 \\
47 \\
45 \\
42 \\
40 \\
37 \\
34\end{array}$ & $\begin{array}{l}69 \\
67 \\
66 \\
64 \\
62 \\
61 \\
59 \\
57 \\
55 \\
53 \\
51 \\
49 \\
47 \\
45 \\
42 "\end{array}$ \\
\hline
\end{tabular}




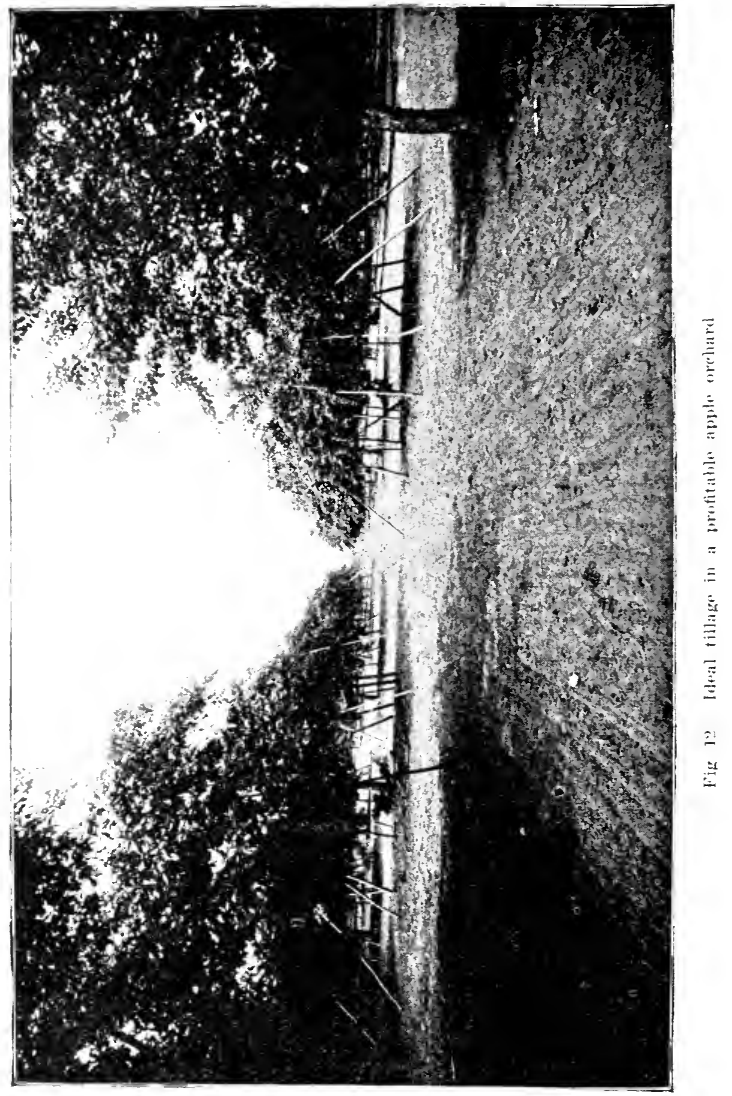




\section{CHAPTER III.}

\section{THE TILLAGE OF FRUIT LANDS.}

THE study of the evolution of the ideas respecting the tillage of the soil opens one of the most interesting chapters in history. The subject is all the more suggestive becanse tillage is such a commonplace and almost universal labor that no one thinks of it as having had a history. Yet the practice of the simple stirring of the soil has been slowly evolved, like all other methods and institutions, through a long period of time, and as the result of many forces which were unobserved or even unknown at the time. We think of tillage as a custom; and if one considers the condition of farming at the present moment, he would seem to be warranted in such an association, for a eustom is a habit which is not suggested by reason and inquiry. Perhaps the only reason which most persons could give for the tillage of the land is that they are obliged to do it. It would seem to be the simplest and dullest thing to till the soil. It is simply the driving of the animal and the holding of the plow, or taking care that the harrow scarifies the entire surface; or it may be only the stubborn wielding of the hoe or rake. This view of the matter is wholly correct 
when one thinks of tillage only as labor. The work must be done because, somehow, plants thrive best when it is done; but the sooner it is done and the less there is of it the easier, and what is the easier is the better.

It was, no doubt, some such mind as this which dominated the rude farmers in the early history of the raee Thronghout all the years until now-and, unfortunately, too often even now-tillage has been a mere necessity forced upon the husbandman by a most ungenerous Nature. The first tillage probably arose from necessity of breaking the earth to get the seed into it; and the seeond step was the digging out of other plants which interfered with its growth. In many eases, still another hardship was imposed, for the earth must be disturbed to get the crop ont of it. These three necessities served to keep the surface of tamed lands in a greater or less state of agitation until it finally eame to be seen that there is something in the practice which canses plants to thrive wholly aside from the lessening of the confliet with weeds. Bnt it is only in the last rentury or two that there appears to have been any serious attempt to discover why this age-long practice of stirring the soil is such a decided benefit to plants.

One reason why the art of tillage has made such slow progress is becanse it seems to be wholly eontrary to the operations of nature. In very reeent rears it has been vehemently proclaimed that the proper treatment of an orchard is to plant it thiek and to allow the leaves and litter to eover the 
ground, wholly omitting the stirring of the soil, for this is the method of the forest; and forest lands increase in fertility from year to year and the moisture is held in them as in a sponge. The reasoning is plausible. There are two ways of testing it,by experience and by reflection. It needs only to be suggested that the experiment has been tried, and is now trying, upon an extended scale, as a large part of the apple orchards of the country testify. The chief beneficiaries of the experiment are the bugs, mice and fungi, all of which would vote the method a success. The reasons why the forest method is successful are because the trees stand so thickly that the earth is protected from the drying effect of sun and winds, the forest cover is so extensive as to produce a climate of its own, all the product is returned to the soil, and there is no haste. In every one of these essentials the orchard is unlike the forest. Those writers who urge that the orchard be planted thick enough to imitate the forest condition, should also make it clear how the insects and fungi are to be kept at bay, or how acceptable fruit can be obtained upon trees which are unpruned and unthinned. The objects to be attained in the forest and in the orchard are wholly unlike. In one case it is the perpetuation of the species, and there results a severe conflict for existence, in which more plants die than reach maturity; in the other it is the securing of an abnormal product of the plant,-a product which ean be kept up to its abnormal or artificial development only by 
abnormal conditions, - and the struggle for existence is reduced to its lowest terms, for it is desired that not a single plant be lost. It is simply becanse it is impossible to imitate the forest conditions that the forest methods eannot be followed in fruit plantations.

Now that we have come to understand why and how it is that the stirring of the soil makes plants thrive, the old-time drudgery of tillage becomes the most important, the most suggestive, and therefore the most diffieult to properly understand and perform, of all purely farming operations. If we camnot have the protection of the forest cover and the forest mulch, we mnst make a mulch for the occasion; and if we wait impatiently for results, we must unlock the granaries of the soil more rapidly than nature does. We must till for tillage's sake, and not wait to be forced into the operation-as men have generally been-by the weeds; yet, whilst we have outgrown the need of weeds, we should not despise them, but remember them kindly for the good which they have done the race. They have been an inexorable priesthood, holding us to duty whilst we did not know what duty was, and they still stand ready to extend their paternal offices.

Coming, now, to the specific question of the tillage of fruit lands, one is struck with the fact that all kinds of fruits are commonly more productive than the apple; and a moment's reflection brings to mind the fact that the apple alone is the fruit which is commonly raised in sod, and which every- 
where receives the least attention. The presumption is at once raised, therefore, that this sod and neglect are in some vital way associated with the declining productiveness of apple trees. In order to put ourselves right upon the question, we must first of all ascertain, if we ean, why the apple is of all fruits the most neglected.

My older reader's will recall the fact that until recent years the effort of the farmer has been directed to the growing of hay, grain and stock. Previous to this generation, the growing of fruit has been a matter of secondary or even incidental importance. A bit of rocky or waste land, or an odd corner about the buildings, was generally given over to the apple orchard, and if the trees received any attention whatever it was after all other demands of the farm had been satisfied. All this was particularly true of the farming previous to the second third of this century, and the apple and standard pear orehards of the country still record the old method. It has required at least a generation of men in which to thoroughly establish any new agricultural system, and the time is not yet fully arrived for the passing out of the old orchards and the coming in of the new. In other fruits than apples and standard pears, the generations of trees are comparatively short-lived, and those fruits sooner feel the effect of new agricultural teachings. Vineyards, and orchards of plums, dwarf pears, apricots, cherries and quinces, have mostly come into existence along with the transition movement from the 
old to the new farming, and they have been planted seriously, with the expectation of profit, the same as the grain crops have. Peaches had passed ont in most parts of the east, and they are now roming in again with the new agricultmre. At the present time, men buy farms for the sole purpose of raising fruit, a venture which would have been a novelty fifty years ago; but the habit of imitation is so strong that the apple planter patterns after the old orchards which were grown under another and now a declining system of agriculture, and many of which are still standing on the old farms of the northeastern states. The apple orchard, therefore, upon the one hand, and the well-tilled rineyard upon the other, are the object lessons whieh illustrate the faults of non-tillage and the gains of tillage.

\section{THE PHILOSOPHY OF TILLAGE.*}

Tillage may be defined as the stirring of the soil for the direct purpose of making plants thrive. Its immediate effect is to ameliorate and modify the soil itself, but its secondary effects are those which are desired, and which are also intimately concerned in the welfare of the plant. For example, tillage is capable of lessening the eapillarity of the surface soil, and from this there may result a saving of moisture from evaporation, and it is the moisture

\footnotetext{
* The reader who desires the fullest and best exposition of tillage in its rarious aspeets should consult "The Soil," by King, and "The Fertility of the Land," by Roberts.
} 
which is sought. For practical purposes, however, it is unnecessary to keep this distinction in mind, and we may classify the benefits of tillage under three general heads, arranging them approximately in their order of importance to the fruit-grower:

1. Tillage improves the physical condition of the land,

(a) By fining the soil, and thereby presenting greater feeding surface to the roots;

(b) By increasing the depth of the soil, and thereby giving a greater foraging and roothold area to the plant;

(c) By warming and drying the soil in spring;

(d) By reducing the extremes of temperature and moisture.

2. Tillage may save moisture,

(e) By increasing the water-holding capacity of the soil;

(f) By checking evaporation.

3. Tillage may augment chemical activities,

(g) By aiding in setting free plant-food;

(h) By promoting nitrification;

(i) By hastening the decomposition of organic matter;

(j) By extending these agencies (g, h, i) to greater depths of the soil.

The simple statements of these offices of tillage is sufficient for the present occasion, except, perhaps, in respect to the improving of the texture of the 
soil and the conservation of the moisture, for if the cultivator is skilled in these latter matters, all the other benefits will follow.

The texture of the soil.-The texture or physical condition of the soil is nearly always more important than its mere richness in plant-food. That is, the productivity of land is not determined wholly, and perhaps not even chiefly, by the amount of fertilizing elements which it contains. This is particularly true of all lands-like the clays-which tend to become and to remain hard and mpleasant if left to themselves. Plant-food is of no consequence unless the plant can use it. The hardest rocks may contain varions plant-foods in abundance, and yet plants cannot grow on them. A stick of wood contains potassium and phosphorus and nitrogen, and yet nothing grows upon it until it begins to decay. A hundred pounds of potash in a stone-hard lump is worth less to a given plant than an ounce in a state of fine division. Soils which the chemist may pronounce rich in plant-foods may grow poor crops.* In other words, the chemist can not tell what a soil will produce; he ean only tell what it contains.

All this is not surprising, when we come to think of it. Every good farmer knows that a hard and lumpy soil will not grow good erops, no matter how much plant-food it may contain. A clay soil which has been producing good crops for any number of years may be so seriously injured by one injudi-

\footnotetext{
* See, for example, Bull. 119, Cornell Exp. Sta.
} 
cious plowing in a wet time as to ruin it for the growing of crops for two or three years. The injury lies in the modification of its physical texture, not in the lessening of its fertility. A sandy soil may also be seriously impaired for the growing of any crop if the humus, or decaying organic matter, is allowed to burn out of it. It then becomes leachy, it quickly loses its moisture, and it becomes excessively hot in bright, sunny weather. Similar remarks may be applied to all soils, although they are not equally true of all.

If these remarks are true, then it follows that it is useless to apply commercial fertilizers to lands which are not in proper physical condition for the very best growth of crops. If potash, for example, were applied to hard lumps of clay, it could not be expected to aid in the growth of plants, because plants cannot grow on such a place. If the same quantity were applied to mellow soil, however, the greater part of it would be presented to the roots of plants at once, and its effects would no doubt be apparent in the season's erop. The improvement of the texture of the soil is not only a means of presenting the plant-foods to the roots of plants and of uniformly distributing what fertilizer may be applied, but it is also a direct means of conserving moisture and of hastening chemical activities.

The soil is a vast storehouse of plant-food, and the first effort of the husbandman should be to make this store available to plants. "Men take him for a foole or a mad man that, having store of 
wealth in his trunck, doth yet complain of want. What though the key be rusty for want of use? tis easier to get that seoured, then to obtaine such another treasure. And surely I may upon most sure grounds say, that our Nutive Countrey, hath in it: bowels an (even almost) infinite, and inexhanstible treasure; much of which hath long laine hid, and is but new begun to be discovered. It may seem a large boast or meer Hyperbole to say, we enjoy not, know not, use not, the one tenth part of that plenty or wealth \& happinesse, that our Earth (an, and (Ingemuity and Industry well encomraged) will (by Gods biessing) yield."*

The moisture of the soil.-Lands oftener need moisture in the growing season than they need fertilizers. The fact is that they generally need both, if the largest and best crops are to be secured. Drought seems to most people to be one of those ralamities in which there are no secondary or incidental blessings, and it must be confessed that the lesson of the recurring droughts has not ret been learned by the great body of farmers. The one remedy which ocenrs to most persons is irrigation, and ret there is suffieient rainfall in most parts of the fruit-growing regions of the country to provide all the needs of large erops. The difficulties are that this rainfall comes when it seems not to be wanted, and very much of it is allowed to escape by evaporation. The truth is that the heavy rainfall

\footnotetext{
* Famuel Hartlib, "An Essay for Advancement of Husbandry-Learning." London, 1651 , p. 3.
} 
usually comes at the best season, for it is the period of inactivity, when the work of the farmer and the growth of the plants are least interfered with. If we, in the east and south, were perfectly certain that we should have no rain from June until September, we should carefully husband the rainfall of the earlier months, and we should suffer little loss; but now that we expect rain all summer long, we neglect the saving of the early rains, and gamble upon the chance of having a rain when we shall need it. It often happens that the dry countries suffer least for water!

How shall we save the water? By holding it in the earth. If the earth is finely divided and yet compact, the capillary pores or interstices will hold enormous quantities of water. If, then, we break up these interstices next the atmosphere, we shall prevent the water from passing off by evaporation. The whole subject of the saving of moisture, therefore, falls into two means, the catching and holding of it (or the making of a reservoir), and the prevention of evaporation. It is, therefore, a question of plowing and then of surface tilling. It will thus be seen how futile it may be to try to save the water by beginning tillage late in the season, when a drought is threatened. If the land has not been well prepared, there may be no water to save by that time. It may either have run through the land into the drains, or it may have evaporated long before the farmer saw the need of saving it. The hard-pan may be so near the surface that but 
little water could get into the land; the dish-pan was shallow, and the early rains made mud-puddles or passed off over the surface. Epon such lands, deep plowing is necessary, in order to break up the hard-pan and to increase the storage rapacity of the soil. If the land is open and leachy, shallow plowing may be necessary, else the soil may be loosened too much. And the water-storage capacity of most soils may be increased by putting humus-or decaying organic matter-into them. It will thus be seen that the methods of conserving or saving moisture must be worked out - or rather thought out-by each farmer for his own farm.

The water of rains and snows is held upon the surface for the time, and allowed to percolate into the soil, if the land is rough and open from recent plowing, if there is a cover of herbage upon the land, or if the surface is soft and mellow. Fall plowing may be advisable in order to catch the water of the inactive season, and also to expose hard soils to weathering, and it may hasten the work of spring. But elay lands with little humus in them may puddle or cement if fall-plowed, and if harrowed and fitted in the fall: and in the south all rolling lands are exposed to serious gullying by fall plowing. As a general thing, it is not advisable to plow fruit plantations in the fall, however, not only because it may too greatly expose the roots to the weather, but because it prevents the ameliorating of such lands by the use of some incidental or catch crop which may be sown after the 
summer tilling is done. The winter covering of plants is quite as efficient in holding the precipitated water as fall plowing is, and the other advantages of it are invaluable (as explained in Chapter IV.).

Any body or substance which is interposed between the air and the moist soil will prevent the evaporation of the moisture. The ground is moist underneath a board. So is it underneath a layer of sawdust or of ashes; and so is it underneath a layer of two or three inches of dry earth. It is expensive and difficult to haul this dry earth onto the land, and, moreover, it soon becomes hard and dense, and is no longer a mulch. It is better to make the mulch on the spot by shallow cultivation, and to repair the mulch as soon as it becomes hard and crusted. The orehardist will, therefore, till as often as the land needs it, however frequent that may be; but as a general statement it may be said that fruit-lands ought to be tilled every ten days and after every rain.

\section{USE OF THE VARIOUS TOOLS IN RELATION TO CONSERVATION OF MOISTURE.*}

Plowing to save moisture.-The first step in the conservation of moisture must be the preparation of the land so that the rain will sink down, and not be carried off by surface drainage. In many sec-

* Adapted from L. A. Clinton, Ball. 120, Cornell Exp. Sta. For a fuller discussion of the subject, consult Roberts' "The Fertility of the Land." 
tions of the country, especially in the southern states, the great bane to agriculture is the surface washing of the soil. Owing to shallow plowing and shallow cultivation, the water is unable to settle into the hard soil with suffieient rapidity, and is carried along the surface, producing those gullies which are there so destructive to farm lands.

The improvements in the plow have done much towards remedying these defects, but there is still much ignorance as to the proper use of this implement. As an implement to be used in the preparation of the soil for the reception of moisture, it stands pre-eminent. Good plowing does not ronsist-as ordinarily supposed-in merely inverting a portion of the earth, but in pulverizing and fining it and burying the sod or refuse which may be on the surface. The amount of water which a soil is capable of holding depends directly upon the fineness of its particles. Then that plow which will break and pulverize the soil most thoroughly is the one best adapted to fit the soil for holding moisture. This point is well illustrated by King in

Note,-Figs. 13 and 14 (pages 147 and 148) are designed to illustrate some of the leading types of tools which are used for tilling fruit-lands. It is not the purpose to recommend these particular tools over any others, or, in fact, to recommend them at all; but simply to show the reader the range of forms which are in common use.

Fig. 13, No. 1, An ideal plow (from Roberts' "The Fertility of the Land"); 2, Syracuse rineyard and garden plow; 3 , Syracuse swivel plow; 4, Mapes subsoil plow; 5, Deere subsoil plow ; 6, 8, Spike-tooth cultivators ; 7, Gang-plow: 9, Spring-tooth eultivator, with side guards; 10, Pearee's orchard gang. plow; 11, Sherwood harness.

Fig. 14. No. 1, Dise harrow ; 2, Spike-tooth harrow; 3, Aeme harrow ; 4, Spring-tooth harrow, with side frames; 5 , Sulky eultivator; 6, Spring-tooth harrow; 7 , Springfield grape-hoe; 8 , Morgan grape-hoe (handle $a$ is a rudder). 


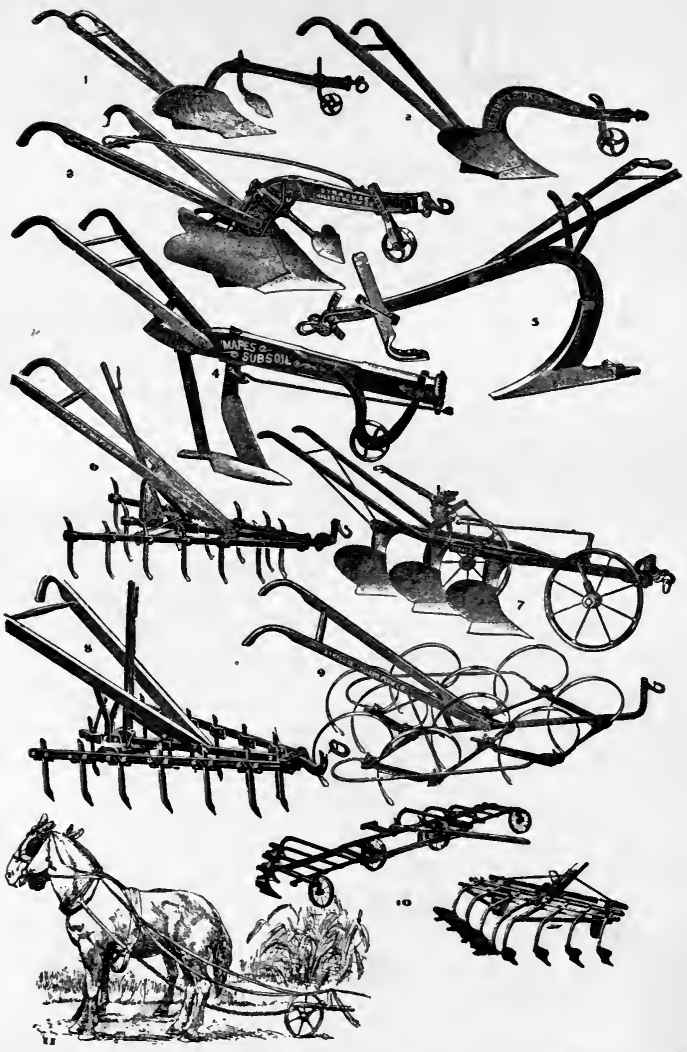

Fig. 13. Various tools adapted to tilling of fruit plantations. (For titles see note, page 146.) 


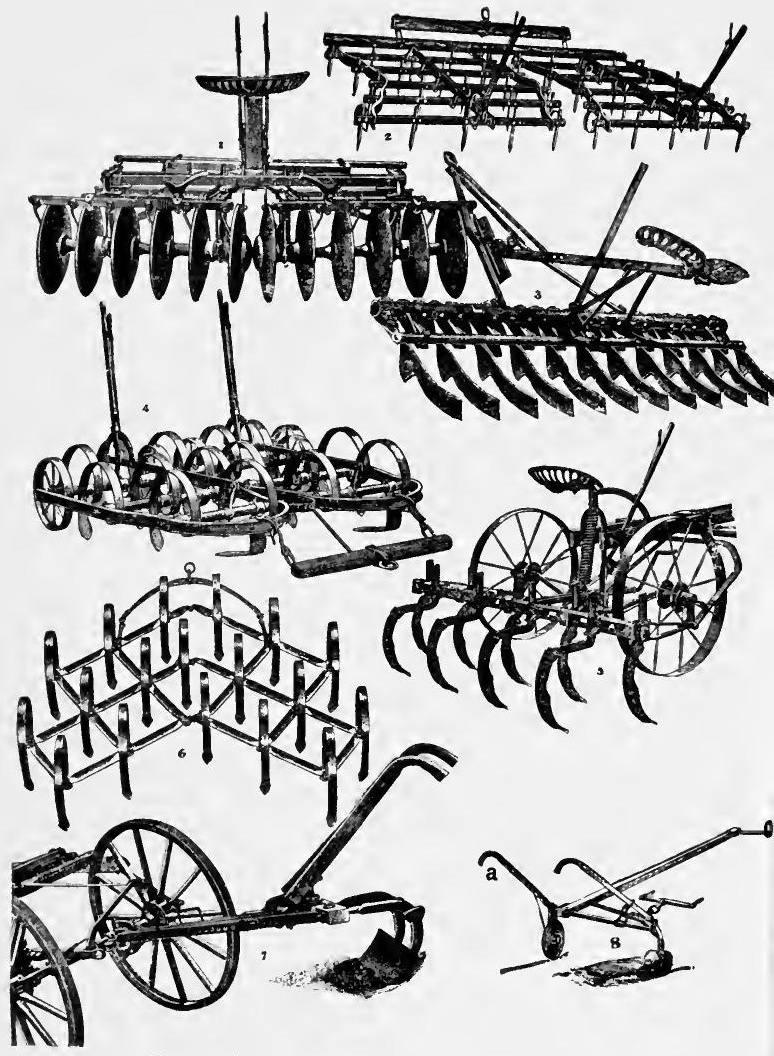

Fig. 14. Tools adapted to surface tilling of fruit-lands.

(For titles see note, page 146.) 
"The Soil." He says: "Since each independent soil grain of a moist soil is more or less completely surrounded by a film of water, it is evident that, other conditions being present, the largest aggregate surface area may retain the most water per cubic foot. Now, a cubic foot of marbles one inch in diameter possesses an aggregate surface of 27.7 square feet, while if the marbles were reduced in diameter to one-thousandth of an inch, then the total area per eubie foot is increased to 37,700 square feet." From this it is evident that the total amount of water capable of being absorbed by a soil which is eloddy and lumpy is very slight in comparison with what it would be were it in a finely divided state; and not only is its absorbing power less, but its power of holding moisture is also greatly reduced.

A large amount of water is lost during the winter and spring months, owing to the surface drainage of melting snows and heavy rainfalls. To prevent this loss, fall plowing may be practiced, and when the subsoil is very hard and compact, the use of the subsoil plow may prove most beneficial. Should the ground break up in clods, then it may be allowed to remain during the winter without harrowing, to more thoroughly subject it to the beneficial action of the elements. But if the soil is in good mechanical condition, and in fruit-land, plants should be growing on it "during the winter.

Harrowing to save moisture.-The harrow, besides 
pulverizing and fining the soil for the seed-bed, is most efficient in furnishing an earth-mulch. The spring-tooth harrow is in reality a cultivator, and its action is similar to that of the cultivator. When used as an instrument to conserve moisture, the teeth should penetrate to the depth of about three inches, and to produce the best effect the ridges left by it should be leveled off by a smoother, which can now be purchased as an attachment to the harrow. The tillage of orchards by the harrow is now practiced extensively, and nothing short of irrigation will so nearly meet the demands of trees for moisture, particularly upon the heavier soils.

The Acme harrow is $\boldsymbol{a}$ most excellent implement on soils which are comparatively free from stones and rubbish. The plow-like action of its blades serves to pulverize the soil, to spread the mulch evenly, and it leaves a most excellent seed-bed.

The cutaway or dise harrows may be either beneficial or of absolnte injury. If the dises are so set that they cover but a portion of the surface with the mulch, they leave a ridge exposed to the action of the wind and sun, and the rate of evaporation is greatly increased. The dises should be set at such an angle that the whole surface shall be stirred or covered. Their chief value lies in their cutting and pulverizing action on clay soils, but as conservers of moisture they are inferior to the Acme or the spring-tooth. Soils which need the dise harrow to pulverize them should generally be gone over again with some shallower tool. 
The mellower the soil, the lighter should be the work done by the harrow. On most heavy orchard soils, it will be found necessary to use the heavy tools, like the spring-tooth and dise harrows, in the spring, but if the land is properly handled it should be in such condition as to allow the use of a spike-tooth or smoothing harrow during summer. This light summer harrowing should be sufficient to keep down the weeds, and it preserves the soilmulch in most excellent condition. With such a tool and on land in good tilth, a man can harrow ten or more acres a day.

Cultivators and conservation of moisture.-The action of cultivators is not materially different from that of the spring-tooth harrow. The size of the teeth should be regulated by the work to be performed, an implement with many small teeth being preferable to one with a few large teeth, when the object is to conserve moisture. It must be borne in mind that in a dry time the less surface exposed the less will be the evaporation. If a large-toothed implement is used to destroy grass and weeds, then it should be followed by a smoother to reduce the ridges and prevent loss of moisture. Ridge culture is only allowable when the object is to relieve the soil of moisture on bottom lands where the water comes very near the surface, or for some special crops, where a high degree of warmth is required early in the season. In these cases, it may be necessary to throw up ridges to produce the proper degree of warmth for germination, but even then the ridges 
should be slight. Nothing could be better calculated to dry out a potato field or a corn field than throwing the ground up in high ridges, leaving a large surface exposed to the action of sun and wind. In fruit plantations which are in a proper state of cultivation, a small-toothed or even spike-toothed cultivator will be fonnd sufficient to maintain the surface mulch.

The roller, in its relation to soil moisture, is an implement whose value depends largely upon local conditions. There is no tool which requires more judgment as to its proper use. On light, loose, sandy or gravelly soils, where every effort must be made to solidify and pack the particles closely together, the roller must be used repeatedly. The difficulty with such soils is that the spaces between the grains are so large that the water is permitted to pass through freely, and is lost by percolation. The capillary openings are so large that there is very feeble rise of the water to take the place of that used by plants and lost by evaporation. The roller lessens the size of these pores in solidifying the soil, and the capillary force is then strong enongh to draw the water to the surface. If, now, the soil is left in this condition, it has been put in the best possible form for parting with its moisture into the atmosphere, and it will take advantage of the opportunity unless prevented by establishing a surface mulch. In seeding land in a dry time, the soil should be rolled in order to bring sufficient moisture to the seeds to insure germina- 
tion. When circumstances will permit, the roller should be followed by a smoothing harrow, that the surface mulch may be restored and the moisture stopped before reaching the atmosphere. On clay lands the roller must be used with much caution. If used immediately after grain is sown and a heavy rain follows, there is danger of the soil becoming so compact on the surface that the tender shoots are unable to get through, and the most direct connection is established between the soil moisture and the air. A good method of treatment for clay is to roll before the seed is sown, then harrow and

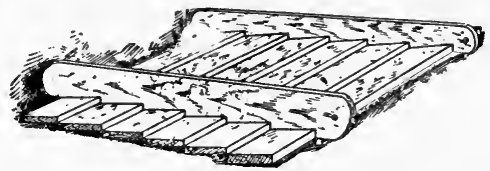

Fig. 15. A planker or float.

make a good seed bed, and then drill in the grain. After the plants are well up the roller may be used again, which will bring the water to the surface, where the growing plants can make use of it before it passes off by evaporation.

Various kinds of plankers or floats may be used in the place of the roller to smoothen and compact recently tilled lands. A good tool of this kind is shown in Fig. 15. "To make this cheap and easilymade adjunct to good cultivation, take two hardwood planks, $2 \times 8$ inches and 7 feet long, and 
notch them as in the cut, boring a hole at the upper end to hitch to; the notches should be 8 inches apart and 2 inches deep; now nail cross planks on the two notched bed pieces, using the same sized pieces, $2 \times 8$ and 6 or 7 feet long; let the cross planks project 1 foot at each end over the bed pieces. If more weight is needed to fine the clay lumps, the driver can ride the float, or weights ean be placed on it. I go over with this float when seeding to grass, and also in fitting strawberry ground. I prefer it to a roller, as it leaves the surface smooth and fine."*

SUGGESTIONS FOR THE TILLING OF FRUIT-LANDS.

Lands which enjoy perfect natural drainage are particularly desirable for orchards, because they are not only warm and give up their fertility easily, but because they also allow of very early cultivation, which is an important requisite in the management of orchards. If this perfect natural drainage does not exist, tile-drainage should be employed until the soil is brought into the best possible condition. It should be said that many hard and wet soils make excellent pear and plum lands when thoroughly tiledrained. It is a common opinion that only flat lands need draining, but one often finds rolling lands in which the subsoil is high and hard, and holds the water like a dish-pan. Judieious draining not only carries off the superfluous water, but it also

*H. L. Barton, in Fruit; quoted in Market Garden, Apr., 1897. 
loosens the subsoil and allows it to retain its moisture better in times of drought. An attempt should be made to bring the land in the various parts of the orchard into conditions as uniform as possible, so that the same tillage and treatment may be applied to the entire area. All hard and "sour" spots should receive particular care in drainage and subjugation, or they should be left outside the plantation.

Lands which have hard and impervious subsoils should be plowed very deep before trees are put upon them; and in some cases, as for dwarf pears, it may pay well to use the subsoil plow. It should be borne in mind, however, that the subsoil plow is not always a fundamental corrective of hard subsoils, for it does not remove the cause. The subsoil may gradually settle back into its old condition, and land cannot be completely subsoiled after it is planted to trees. In the case of strawberries, raspberries, and other short-rotation fruits, the subsoil plow may be used at frequent intervals; but in lands which are to be planted to orchards, the tile drain is a more perfect ameliorator of the subsoil than the subsoil plow is. Yet even the one subsoiling may serve a useful purpose in sending the roots downwards at the start, and this advantage will be the greater when the superfluous water removes itself rapidly from the hard-pan.

The soil in which orchards are set should always be in a thorough state of cultivation at the time the trees are planted; that is, whether in sod or in hoed crops, the land should be in good tilth or physical 
condition, fertile, and free from hard or "sour" places and pernicious weeds. There are exceptions to this rule in the case of certain rocky or steep lands npon which it is desired to set apples; but for all orchards which are planted directly for commercial results, this advice has few, if any, exceptions. It is generally best to put the land into hoed crops the season before the trees are set, as potatoes or eorn; although sod land, if well fitted and naturally in good heart, often gives exeellent results when turned over and set at once to orehards. But most soils need the previous enltivation to bring them into a mellow and uniform condition. Many of the "bad places" in orchards, where trees die out the first two or three years, conld have been discovered and corrected if the land had been devoted to one or several hoed crops, for the owner would have observed that theywere too wet or too humpy, or had other serious defeets. Lands look more uniform when in sod than when eultivated, and the farmer may be led to overestimate their value for orehard purposes. It may also be said that the familiarity with a particular piece of land, which comes of frequent cultivation, enables the careful grower to judge accurately of its adaptability to particular fruits or even to special varieties.

The best tillage is that which begins early in the season, and which keeps the surface stirred until late summer or early fall, and the best implements are those which secure this result with the least amount of time and labor. For the first few years, it is gen- 
erally advisable to turn the land rather deep with a plow at the first spring eultivation. For the subsequent enltivation of the season, there are many styles of clod crushers, spring-tooth harrows, eut-aways and smoothing harrows, which adapt themselves readily to the cultivation of the particular soil in question. There is no single style of tool which is best for all soils or for all years. As a general statement, it may be said that for all heavy lands the fruit-grower needs four types of harrows, - the cut-away, or spading-harrow type for hard land, and the first spring work; the spring-tooth type, the Acme or clod-crusher type, and the smoothing-harrow type. The last is to be used only to make and maintain the surface mulch after the land has been got in fine tilth. In all friable or loose soils, shallow cultivation is always preferable. When the land is once in good condition, but little effort and time are required to run through the orchard. Crust should never be allowed to form upon the surface, and weeds should be killed before they become firmly established. The entire surface of the orchard should be thoroughly stirred as often as once in ten days or two weeks whilst the tillage lasts.

In general, level culture is best. This is secured by plowing one year to the trees and the following year away from them; one year north and south, and the next year east and west. It is somewhat difficult to plow away from large trees, however, and with the eultivators or harrows now in use, it is easy to work the soil away by subsequent cultivation, allowing the 
furrow to be thrown towards the tree each spring, particularly if the land is in good tilth; but it is always advisable, upon fairly level ground, to plow the orchard in opposite directions in alternate years. Land which is so wet that it needs to be thrown

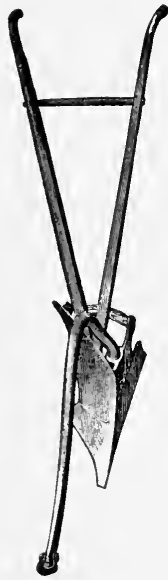

Fig. 16. Set-over beam vineyard plow. permanently into ridges for drainage is not often adapted to fruit.

The difficulty of working elose to the trees has had the effect of encouraging too high pruning. There is a tendency to start tops too high rather than too low, thereby exposing great length of trunk to injuries of sun and wind, and elevating the top beyond the reach of pickers and of sprays. For most trees the ideal length of trunk is under five feet rather than above it, and implements now in the market allow of this lower training. Trees which have low tops, or which hang low with fruit, cau be reached by separating the halves of any of the donble harrows by means of a long donbletree, so that the halves, when adjusted, run from four to six feet from each other. A cut-away harrow rigged in this manner will work away the back-furrows from under the trees during the season. All cultivators or harrows with high handles, wheels or levers should be discarded if orchards are worked when the limbs 
bend low with fruit. An implement of the grapehoe type may be used with advantage in some cases to loosen the earth about the trees. A single-horse plow, with a set-over beam (as in Fig. 16), is also most excellent for plowing close to trees and bushes. The objection to. medium-low heads to trees arises from the use of the old-fashioned implements of tillage, and also from a misconception of what the plowing of an old orchard should be, for if the orchard is properly cared for in its earlier years, heavy plowing will not be needed in its later life.

This labor of working about trees is greatly facilitated by the use of harnesses which have no metal projections. There should be no hames with elevated tops, and the turrets on the back-pads should be simply leather loops. The back-pad itself should be reduced to a single wide strap entirely devoid of wadding. Harnesses of the Sherwood type, with no traces, but drawing by a single chain between the horses, are excellent in orchards, as they require no whiffletrees, and they are likewise handy and efficient.

The better the plowing and other tillage of the orchard in the first few years of its life, the easier and more efficient the subsequent plowing will be. If care is taken to keep the land friable and well-filled with humus, it may not be necessary to turn furrows at the spring plowing after four or five years. Persons commonly suppose that an orchard must be plowed the same as corn or potato ground is, by inverting the land and running regular furrows; but inasmuch as the object is simply to keep the land 


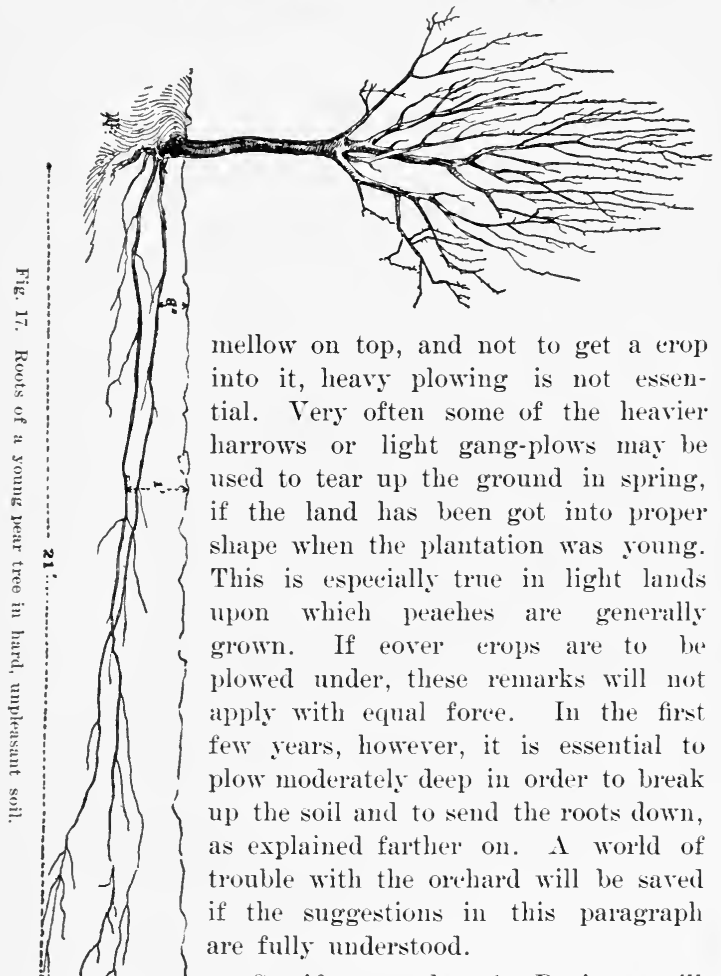

Specific remarks. - 1. Begin to till when the orchard is planted, and till the entire surface. If trees are prop- 
erly set, and if cultivation is begun the first year, the roots will go deep enough to escape the plow. The roots of trees spread much farther than the tops. I will give some examples from trees of which we have carefully measured the tops and roots. Fig. 17 shows a standard Howell pear tree set in 1889 and photographed in 1895. It grows on a hard clay knoll. The full spread of the top is seven feet. Two roots were laid bare, and they ran off in one direction to a distance of twenty-one feet. Assuming that they ran an equal distance in the other direction, the spread of roots was forty-two feet, or just six times that of the top. And yet it is commonly said that the spread of roots and tops is about equal! Now, these roots were long and whip-like. The soil was so poor that they were obliged to search far and wide for pasture. Compare Fig. 18. This is a Fall Orange apple, also set in 1889, in rich, well tilled soil. Here the roots are in good pasture, and they remain at home; yet their spread is twice that of the top. The top of this tree had a diameter of eight feet, and we followed the roots eight feet upon the side in which we dug. These object lessons enforce the importance of tilling all the land between trees.

But these figures teach another lesson. Even at their highest point, the roots of Fig. 17 are eight inches below the surface. They escape the plow. A like remark applies to Fig. 18. Now look at Fig. 19. This tree is the same age as the others, but has always stood in sod. The roots ran ten feet in one direction and the total 
spread of the top was six feet; but the roots lie just underneath the surface. This land could not be plowed without great injury to the tree. Let us consider the relation of this tree to moisture: the roots are in the driest part of the soil; the grass is pumping ont the water and locking it up in its own tissues and sending it into the atmosphere with great rapidity; the soil is baked, and pulls up the water by capillary attraction and discharges it into the air ; there is no tillage to stop this waste by spreading a mulch of loose and dry soil over the earth. If

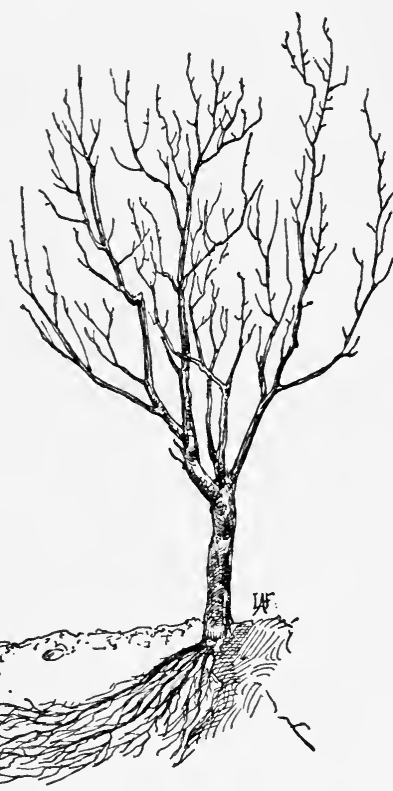

Fig. 1s. Roots of a young apple tree in rich tilled land.

one were to sink a well under this tree and were to erect a windmill and pump, he could not so completely deprive the tree of moisture! And the 
less moisture, the less food! And yet this is a common method of treating fruit-trees!

In young orchards, then, it is commonly best to plow rather deep-say six to eight inches-in order to send the roots down. Of course, the plow should not be run deep close to the trunk of the tree. The careful plowman will turn out his plow when he comes within a couple of feet of the tree. This deep plowing for a few years will ameliorate the land, establish the root-habit of the tree, and obviate the necessity of laborious plowing in after years.

2. Tillage should be begun early in the season, in orchards. Trees complete most of their growth by the first of July. Early tillage saves the moisture

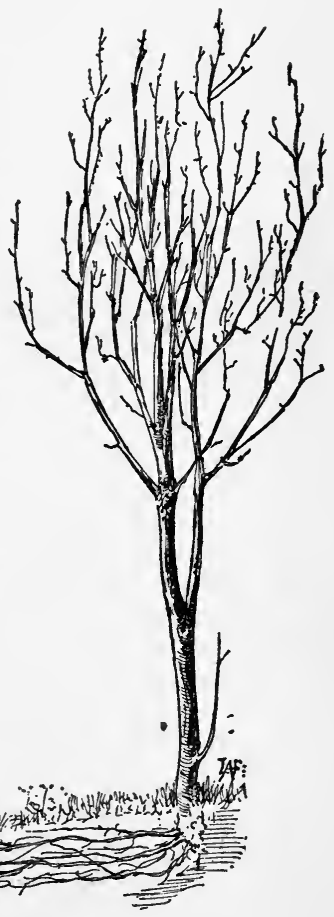

Fig. 19. Roots of a young apple tree in sod land. 
which has aecumulated during the winter and spring; it is capable of putting the soil in fine meehanical condition, and this condition is as important as fertility; it warms up the soil and sets the plants quickly to work; it turns nuder the herbage when that herbage is soft and moist and when there is moisture in the soil, so that the herbage soon breaks down and deeays. All eateh erops on the orchard should be plowed under just as soon as the ground is dry enough in the spring, for these crops soon pump the water from the soil and cause it to bake and cement together, and the longer they remain the more difficult it is to eause them to rot when turned under. Hard and woody herbage, plowed under late in the season, may remain as a foreign body in the soil all summer, breaking the eomnection between the upper and the lower soil, and thereby preventing the upward movement of the water and causing the top soil to completely dry out. The chief value of erimson elover, rye, or other eatch erop in the orchard lies in its fall growth and its protection of the soil in winter, not in its growth in spring.

Few people are aware that the season of growth in most woody plants extends searcely to midsummer. It is worthy of note that most, if not all, native trees and shrubs cease growing very early in the season. This is no doubt one reason why they are able to endure the winter. Plants whieh cease growing early, and whieh mature their wood well, are often said to be determinate in their growth, 
while those of opposite habit are said to be indeterminate. It is, of course, apparent that plants of indeterminate growth are not hardy, as a rule. A series of careful measurements of growth was made upon various trees and shrubs at Lansing, Michigan, in 1886, and some of the records are presented below.* The last date in each ease designates the termination of growth for the year. It will be observed that very few of the plants grew until July. This fact is illustration and proof that in our rigorous climate cultivation should stop early, and that it should be vigorous at the opening of the season.

\section{RECORDS OF GROWTH. $†$}

Acer dasycarpum-May 12th, 1 in.; 16th, 2 in.; 25th, 4 in.; June 6th, 7 in.; 13th, 9 in.; 20th, 10 in.; 29th, 12 in.

*Acer Pennsylvanicum-May 12th, 2 in.; 18th, 4 in.; 20th, 5 in.; 26 th, 7 in.

Acer platanoides-May 12th, 3 in.; 16th, 4 in.; 20th, 5 in.

Acer Pseudo-Platanus-May 14th, 6 in.; 18th, 8 in.; 16th, 12 in.; 30 th, 13 in.; June 6th, 20 in.; 13th, 23 in.; 20th, 24 in.

Acer rubrum-May 26th, 5 in.; 30th, 6 in.; June 6th, 9 in.; 13 th, 10 in.

* Bailey, Bull. 31, Mich. Agr. College, 73.

† In making the measurements recorded above, one average shoot was selected on each plant, and measured from time to time during the growing season. The drought may have checked growth to some degree, althongh it did not become severe until the end of June. Most of the plants stood upon the campus, with no cultivation. A few were younger, and stood in the rows of a closely planted arboretnm, where they received occasional eultivation, or in a newly-planted gronp, where the soil was frequently hoed; these plants are designated by asterisks. 
Acer spicatum-May 18th, 1 in.; 20th, 2 in.; 30 th, 3 in.; June 6 th, 5 in.; 13th, 6 in.; 29 th, 10 in.; July 5 th, 11 in., 11 th, 12 in.

Esculus glabra-May 12th, 5 in.; 14th, 10 in.; 18th, 11 in.; 20th, 12 in.; 26th, 13 in.; 30th, 14 in.

Esculus Hippocastanum-May 5th, 2 in.; 12th, 5 in.; 14 th, 7 in.; 20 th, 10 in.; 25th, 13 in.; 30 th, 13 in.

Eseulus parviflora-Nay 5th, 2 in.; 25th, 6 in.; June 6 th, 8 in.; 10 th, 9 in.; 16 th, 10 in.; 29 th, 12 in.

Aluus glutinosa-May 14th, $1 / 2$ in.; 18th, 1 in.; 30th, 2 in.; June 6 th, 3 in. ; 20th, 4 in.

*Aluus maritima-May 20th, 1 in.; 26th, 2 in.; June 1st, 3 in. Aluus serrulata-May 18th, 4 in., 25th, 8 in.; 30th, 12 in.; June 6 th, 13 in.; 13 th, 14 in. ; 20 th, 16 in.

Amelanehice Canadensis-May 12th, 1 in.; 14th, 2 in.; 18th, 3 in.; 20th, 4 in.; 26th, 7 in.; 30 th, 8 in.

Amorpha frutieosa-May 12th, 1 in.; 14th, 2 in.; 18th, 4 in.; 20 th, 6 in. ; 26 th, 10 in.; 30 th, 11 in.; June 6th, 12 in.

Ampelopsis quiuquefolia-May 26th, 14 in.; 30 th, 16 in.: June 6 th, 24 in.; 13th, 30 in.; 20th, 36 in.; 29th, 38 in.

Aralia spinosa-May 26th, 4 in.; 30 th, 5 in.; June 13th, 51/2 in.; 20 th, 6 in.

Berberis vulgaris-May 26th, 8 in ; June 1st, 12 in.; 6th, 14 in.; 13 th, $17 \mathrm{in} \mathrm{;} \mathrm{20th,} 18 \mathrm{in.;} 29$ th, :0 in.

Betula alba, var.-May 12th, 1 in.; 20th, 2 in.; 25th, 4 in.; 30 th, 5 in.; June 6 th, 7 in.; 10 th, 8 in.; 19 th, 10 in.

${ }^{*}$ Betula lenta-May 26th, 1 in.; June 1st, 2 in.; 13th, 6 in.; 20 th, 10 in.

Betula lutea-Nay 25th, 1 in.; 30 th, 2 in.; June 6th, 3 in.; 13th, 4 in.; 29th, 5 in.

Betula papyrifera-May 18th, 1 in.; 20th, 2 in.; 26th, 3 in.; June 1st, $3 \frac{1}{2}$ in.; 6 th, 4 in.; 20 th, 5 in.

* Betula alba var. populifolia-May 18th, 1 in.; 20th. $1 \frac{1}{2}$ in.; 26 th, 3 in.; June 1st, 4 in.; 6 th, 6 in.; 13th, 7 in.; 19th, 12 in.; 29 th, 14 in.

Carpinus Caroliniana-May 25th, 1 in.; 30th, 2 in.; June 6th, 4 in.; 13 th, 5 in.; 20 th, 6 in. 
Carya alba-May 20th, 3 in.; 30th, 8 in.; June 6th, 9 in.; 13th, $9 \frac{1}{2}$ in.

Carya amara-May 25th, 3 in.; 30th, 31/2 in.; June 3rd, 4 in.; 13 th, $4 \frac{1}{2}$ in.

${ }^{*}$ Carya suleata-May 18th, 6 in.; 20th, 8 in.; 26th, 12 in.; June 1st, 14 in.

${ }^{*}$ Castanea pumila-May 18th, 3 in.; 20th, 4 in.; June 19th, 12 in.

Castanea vesca-May 16, 1 in.; 26tn, 2 in.; June 1st, 21/2 in.; 13th, 3 in.

${ }^{*}$ Catalpa Kampferi-May 16th, 5 in.; 18th, 6 in.; 26th, 12 in.; 30 th, 14 in.; June 6th, 16 in.; 13th, 20 in.; 20th, 24 in.; 29th, 28 in.

Celtis occidentalis-May 18th, 3 in.; June 13th, 10 in.

${ }^{*}$ Cercis Canadensis-May 18th, 2 in., June 29th, 15 in.

Cladrastis tinctoria-May 9th, 1 in.; June 20th, 18 in.

Cornus florida-May 25th, 2 in.; 30th, 21/2 in.; June 6th, 3 in.; 13th, 4 in.; 20th, 5 in.; 29th, 6 in.

${ }^{*}$ Cornus Sibirica-May 16th, 1 in.; June 29th, 12 in.

Cratcogus Crus-galli-May 9th, 1 in.; June 13th, 7 in.

Cratagus Oxyacantha-May 12th, 3 in.; June 29th, 22 in.

${ }^{*}$ Euonymus atropurpureus-May 18th, 6 in.; June 19th, 13 in.

Fagus ferruginea-May 18th, 2 in.; 26th, 5 in.; 30th, 8 in.

*Fraxinus pubescens-May 14th, 2 in.; 18th, 4 in.; 20th, 6 in.; 26 th, 8 in.

Gleditschia triacanthos-June 1st, 2 in.; 20 th, 12 in.

Liriodendron Tulipifera-May 26th, 1 in.; 30th, 2 in.; June 6th, 3 in.; 29th, 5 in.; July 5th, 6 in.

${ }^{*}$ Maclura aurantiaca-May 18th, 1 in.; July 10th, 37 in. Magnolia acuminata-May 20th, 1 in.; June 29th, 6 in.

Philadelphus coronarius-May 12th, 3 in.: June 19th, 19 in.

Platanus occidentalis-May 26th, 1 in.; July 5th, 9 in.

*Platanus orientalis-May 18th, 3 in.; 20th, 4 in.; 26th, 8 in.; June 1st, 12 in.; 6 th, 16 in.; 13th, 24 in.; 29th, 40 in.; July 11th, 44 in.; 25th, 52 in.; Aug. 3d, 56 in., still growing.

*Populus alba var. Bolleana-May 12th, 2 in.; August 3rd, 32 in. 
Populus grandidentata var. pendula-May 12 th, 21/2 in.; June 29 th, 17 in.

Populus monilifera-Nay 16th, 2 in.; June 19th, 6 in.

Prunus nuna-May 16th, 3 in.; 26th, 5 in.; June 1st, 7 in.

Prumus Pissardii-May 8th, 5 in.; June 13 th 10 in.

Prunus serotina-Nay 12 th, 7 in.; 30 th, 14 in.

Prunus Tirginiana-May 12th, 3 in.; 26th, 6 in.

Pyrus Aucuperia-May 3d, 1/2 in.; June 6th, 12 in.

*Pyrus Malus-May 9th, 2 in.; 26th, 8 in.

Quercus alba-May 12th, 2 in.; 18th, 6 in.; 26 th, 13 in.

*Quercus bieolor-May 9th, 2 in.; July 5th, 12 in.

Quercus coccinea var. tinetoria-May 12th, 1 in.; June 13th, 7 in.

${ }^{*}$ Quercus ilicifolia-May 14th, 3 in.; June 6th, 13 in.

*Quercus imbricaria-May 12th, 2 in.; June 6th, 20 in.

Quercus maerocarpa-May 16th, 4 in.; 20th, 6 in.; 25th, 12 in.; 30 th, 13 in.; June 6 th, 14 in.

Quereus nigra-May 12th, 5 in.; June 6th, 14 in.

Ribes floridum-May 12 th, 2 in.; June 6 th, 12 in.

Robinia hispida-May 18th, 2 in.; June 19th, 12 in.

Robiniu Pseudacaeiu-May 12th, 1 in.; 18th, 2 in.; 26th, 3 in.; 30th, 4 in.: June 6th, 5 in.; 13th 6 , in.; 20th, 7 in.; 29th, 9 in.; July Eth, 10 in.

* Salix Babylonica-May 9 th, $1 / 2$ in.; 12th, 2 in.; 16th, 3 in.; 20th, 4 in.; 26th, 6 in.; June 1st, 12 in.; 13th, 16 in.; July 11 th, 27 in.; 19th, 34 in.; 25th, 40 in.; Aug. 3d, 42 in.

Syringa vulgaris-May $3 \mathrm{~d}, 4$ in.; 9 th, 8 in.; 12th, 12 in.; 18 th, 13 in.; 26th, 14 in.

Tilia Amerieana-Nay 14th, 2 in.; 18th, 3 in.; 20th, 5 in.; 26th, 11 in.; June I, 12 in.; 6th, 13 in.

Vitis riparia-May 14 th, 1 in.; 30 th, 15 in.

3. Tillage should generally be stopped in late summer or very early fall. The tree has completed its growth. It must now ripen and prepare for winter. It ean spare some of the moisture which comes with 
the fall rains. We may, therefore, sow some catch or cover crop. (See Chapter IV.)

4. Till in such manner that the land shall be in uniformly fine tilth. Every good farmer knows that the value of his crop depends more upon the tilth of the soil than upon the mere richness of it. Fertility is largely locked up in poorly tilled lands. Orchards which are plowed late in spring are usually in bad condition all the season, especially if the soil is clay. Fall plowing upon stiff and bare lands is apt to result in the puddling of the soil by the rain and snow, as already explained; if there is sod on the land, this injury is less likely to follow. In general, it is best to let orchard lands pass the winter under a catch crop.

5. Remember that tillage may be overdone. Trees may be made to grow too much wood, and therefore too little fruit, and they may be sent into the winter in soft and unripened condition. If land is in good tilth, as it is when in best condition for the growing of potatoes or melons, tillage beyond that needed to conserve the moisture is useless; and even this conservation-tillage may well stop in late summer in very many cases, as already indicated It is a common practice to severely head-in trees which are making a too vigorous growth, but this practice usually aggravates the difficulty rather than corrects it. The fundamental treatment for such trees is to check the growth by some means, as by lessening the tillage or by withholding stimulating fertilizers. 


\section{CROPPING THE ORCHARD.}

It will now be asked what crops may be grown in the orchard. Grain and hay, never! Any hoed crop may be used for the first few years; but it must be remembered that every erop eompetes with the trees for food and moisture, and whatever may befall the erop, the trees should not be allowed to suffer. An open space should be left about the tree, free of crops, at least several feet in extent. As a general statement, it may be said that a space three feet wide should be left upon all sides of the tree the first year, and this area should be enlarged a foot or two each year; and this space should continue to enlarge until the trees occupy the entire surface. Corn and some other luxuriant plants appropriate moisture more quickly than the tree ean. In general, some low-growing crop which demands good tillage and comes off the land early is best. The notion that young trees should be shaded by a crop is probably erroneous for most regions. In orehards set less than twenty feet apart, the land should rarely be cropped after the third year; but apple orchards, if well eared for, may be cropped lightly for seven or eight years. In no ease should the grower expect to secure as mueh erop upon orchard land as upon other areas; and the drier the land, the less should it be cropped. When the orchard comes to bearing age, give it the entire land. Thereafter, the most profitable secondary crop to raise is eultivators. 
In general, it may be said that only those erops are allowable in a fruit plantation which demand such treatment as to improve the land for the fruit plants. The growing of light crops is a means of keeping the land stirred when it might otherwise be neglected; and if the grower is careful to see that the physical condition of the land is improved, and adds enough plant-food to supply the loss, the light cropping of orchards for the first few years may be a decided benefit. At all events, cultivated crops are better than sod. The danger is that the fruitgrower will continue the eropping too long, and expect too much from it. In an orchard, the crops ought to pay for taking eare of the land until the trees come into bearing. Strawberries and the bush fruits may be advantageously set in alternate rows with beans or potatoes, and the same tillage is required for each crop.

Only annual crops should be grown in fruit plantations. The growing of nursery stock in orchards -a frequent practice in parts of the north-should be discouraged.* This erop makes essentially the same demands upon the land as the orchard itself, and it does not allow of those variations in cultivation and management which may be essential to the varying seasons. It may be true that enough fertilizer can be placed upon the land to replace the loss of plant-food, but it is rarely doue; and, more than this, the nursery stock drinks up the moisture

\footnotetext{
*The double-planting of fruit lands-the mixing of different kinds of fruits -is discussed in Chapter V.
} 
which should be used by the orchard. Nursery stock is known to be particularly hard upon land, so much so that nurserymen seldom grow two erops of fruit-tree stocks in succession upon the same area; but this injury to the land is an impairment of physical condition rather than exhaustion of plantfood. (See Chapter IV.)

Sod may sometimes be allowed in an orchard if it is closely pastured, but hay should never be cut. Sod lands are not only drier than cultivated ground, but they are favorite breeding places of inseets. Borers are particularly bad in grass land. No stone fruits should ever be allowed to stand in sod, and the same may be said of dwarf pears. Apples and standard pears may now and then be seeded with safety, but it is certainly true that, in general, fruit decreases in proportion as sod increases. Very thrifty young apple and pear orehards may sometimes be thrown into bearing by seeding them down for a time, but the sod should be broken up before the trees become rhecked in vigor. The whole question as to whether sod is hurtful or beneficial to an orchard is a local one. The grower must determine it for himself. If the orchard is in sod and is not doing well, the best advice in general is to plow and till it. Certainly it is better to make tillage the rule and sod the exception, than to start out with the intention of growing an orehard in grass and cultivating it only when forced to do so. It is better to pasture an orchard than to allow the grass to grow at will, but close pasturing ean by no means take the place of tillage. 
If one wants to raise hay or grain, it is cheapest to grow it where there are no trees to bother. If he wants to grow apples or grapes, he had better choose some other place than a meadow or grain field. The use of clover and other temporary cover crops as a means of fertilizing the land is another matter, and is discussed in the next chapter.

Most apple orchards are in sod, and growers are always asking if they shall be plowed up. If the growers of apples are satisfied with the crops, let the orehards alone; but if it is thought that better crops are desirable, do not hesitate to make an effort to obtain them. It is surprising that the disastrous failures of recent years have not awakened farmers to the necessity of really doing something for their orchards. Now and then an enterprising man makes an energetic attempt and is rewarded, but the greater number continue to exercise the most thoroughgoing neglect and to bewail the failure of the crop. Yes, plow the old apple orchard; then fertilize and spray it. Or, if the roots are too near the surface to allow of plowing, harrow it thoroughly when the turf is soft in spring, and continue to work it during the season. If this is not feasible, then pasture it closely with sheep or hogs, feeding the stock at the same time. If this cannot be done, and the orchard is unprofitable, cut it down.

When orchards begin to bear well, the crops should be discontinued. Young orchards may sometimes be summer-fallowed with the very best results if the land is hard and intractable. This fallowing 
is clean cultivation. This is often the quickest and cheapest way of bringing such lands into fit condition for the growing of the fruit, and the longer the process is delayed after the plants are set, the more difficult and the less efficient the labor will be. This summer-fallow should be begun very early in the season and continued until midsummer, at which time some cover crop may be sown. 


\section{CHAPTER IV.}

\section{THE FERTILIZING OF FRUIT LANDS.}

ANY land which is fit for the growing of crops will mairtain a fruit plantation throughout its existence without the addition of plant-food, and enable the trees to produce at the same time a normal quantity and quality of fruit. But the profit in fruitgrowing lies in securing the extra normal or superior quantity and quality, and this result demands fertilizing of the land and every other good eare. How much plant-food the farmer should add to his land depends upon the amount of increase or profit which he secures. It is a matter of business, an item of profit and loss. If the fruit-grower applies five tons of fertilizer to every acre and secures a profit on the investment, the quantity is none too large; but in many instances it is a loss of the material to add anything. The successful merchant is the one who is dissatisfied with a normal and common trade, but he forces the demand by attracting and interesting his eustomers beyond the point of their actual needs.

There are many eauses which eontribute to the unsatisfactory results of applying fertilizers, but the commonest one is lack of proper tillage and preparation of the land. Poorly-tilled land, as we have 
seen, not only refuses to rield up its own stores of wealth, hut it will delay and even preclude the goor results from plant-foods which may be added to it. The first thing to do, then, is to make it possible for the plant to grow. Make the physical and environmental conditions right, and the addition of plant-food will be felt and appreciated. The plant must be made comfortable before it will thrive. A cow will not relish even the fanciest ration if she shivers with cold.

The grower must set himself in line with natural methods. He must see that the soil has a good supply of humus or decaying organic matter (got from erops turned under, dressings of stable manure, muck, and the like), and that it generally has some eover upon it. Early in the season, this cover is the surface muleh of cultivated soil, and later it is the eover crop of rye or crimson elover, or sometling of the kind.

Nature is a kindly and solicitous mother. She knows that bare land becomes unproductive land. Its elements must be unlocked and worked over and digested by the roots of plants. The surface must be covered to eatch the rains and to hold the snows, to retain the moisture, and to prevent the baking and cementing of the soil. The plant tissues add fiber and richness to the land, and make it amenable to all the revivifying influences of sun and rain and air and warmth. The plant is co-partner with the weather in the building of the primal soils. The lichen spreads its thin sub- 
stance over the rock, sending its fibers into the crevices and filling the chinks, as they enlarge, with the decay of its own structure; and finally the rock is fit for the moss or fern or creeping vine, each newcomer leaving its impress by which some later neweomer may profit. Finally the rock is disintegrated and comminuted, and is ready to be still further elaborated by corn and ragweed. Nature intends to leave no vacant or bare surfaces. She providently covers the railway embankment with quack-grass or willows, and she scatters daisies in the old meadows where the land has grown sick and tired of grass. If one pulls up a weed, he must quickly fill the hole with some other plant, or nature will tuck another weed into it. Man is yet too ignorant or too negligent to care for the land, and nature must still stand at his back and supplement the work which he so shabbily performs. She knows no plants as weeds. They are all equally useful to her. It is only when we come to covet some plant that all those which attempt to crowd it ont become weeds to us. If, therefore, we are competent to make a choice of plants in the first place, we should also be able to maintain the choice against intruders. It is only a question of which plants we desire to cultivate.

We must keep the land at work, for it grows richer and better for the exercise. A good crop on the land, aided by good tillage, will keep down all weeds. The weeds do not "run out" the sod, but the sod has grown weak through some fault of 
our own, and thus the dandelions and plantains find a chance to live. So the best treatment for a weedy lawn is more grass. Loosen up the poor places with an iron garden rake, scatter a little fertilizer, and then sow heavily of grass seed. Do not plow up the lawn, for then you undo all that has been accomplished; you kill all the grass and leave all the ground open for a free fight with every ambitious weed in the neighborhood. If the farmer oeeupies only half the surface of his field with oats, the other half is bound to be occupied with mustard or wild carrot or pigweed; but if his land is all taken with oats, few other plants cau thrive. So, a weedy farm is a poorly farmed farm. But if it does get foul and weedy, then what? Then use a short, quick, sharp rotation. Keep the ground moving or keep it covered. No Russian thistle or live-for-ever or jimson-weed can ever keep pace with a lively and resourceful farmer.

\section{THE LESSON OF NURSERY LANDS.}

The injurious effects of leaving soils bare, and of tilling at untimely seasors, are well illustrated in most nursery plantations. The best nursery lands are the "strong" lands, or those which contain a basis of clay, and these are the ones which soonest suffer under unwise treatment. The nursery land is kept under clean culture, and it is, therefore, deeply pulverized. There is practically no herbage on the soil to protect it during the winter. 
When the crop is removed, even the roots are taken ont of the soil. For four or five years, the land receives practically no vegetation which ean rot and pass into humus; and then, the trees are dug in the fall, often when the soil is in unfit condition, and this fall digging amounts to a fall plowing. The soil, deeply broken and robbed of its humus, runs together and cements itself before the following summer; and it then requires three or four years of "rest" in clover or other herbage erop to bring it back into its rightful condition. This resting period allows nature-if man grants her the privilege-to replace the fiber in the soil, and to make it once more so open and warm and kindly that plants can find a congenial root-hold in it.

The following synoptical sketch of the causes of the so-called wearing-ont of nursery lands will serve to bring the question of productivity of lands into its proper relationships and perspectives:*

a. The fertility of the soil.-There are two analytical means of determining the fertility of the land. One method determines the chemical constitution, and the other the mechanieal or physical condition.

Chemistry determines the amount and kind of plant-food in the soil, but it cannot tell just how useful this food may be to the plant. This depends upon the physical condition of the land, or upon the relation of the soil to warmth, moisture, air and mechanical constitution. The plant is not simply a passive agent, taking in the food which is presented to it, but it is actively engaged in searching for and appropriating food.

* L. H. Bailey, before American Association of Nurserymen, at Chicago, as reported in Garden and Forest, June 24, 1896. 
The actual fertility of the soil depends, therefore, upon the plant as well as upon the land. The better and more comfortable the plant, the more food it can appropriate from a given soil; hence that soil is practically the richer. The chemist does not determine the physical conditions which make the plant comfortable and active. In other words, the umount of plant-food in the soil is only one of the elements in the fertility of the land.

In most instances as much depends upon the physical condition of the soil as upon its ehemical constitution, and in many cases even more depends upon it.

Soil is derived from two sources-rock and organic matter. Each is essential to it. Without the rock matter it would lose body and staying qualities. Without the organie matter it would lose life, or "heart" and activity.

Nature adds the organic matter to the soil by growing plants upon it and then incorporating their remains with it. Everywhere the process of soil-building is now going on. The longer the soil is in erops the richer it becomes, although the relative amount of mineral matter which it contains may be decreasing at the same time.

Nature makes the soil richer, then, both by fining and digesting the mineral matter and by ameliorating its physical condition through the incorporation of humus or organic matter.

This fining process must ultimately cease, but the addition of humus never ceases. The final and complete enrichment of the soil, therefore, must come largely as the result of the incorporation of humus with it.

The chief value of this liumus is not to directly afford plant-food, but to improve the conditions of temperature, moisture, aëration and the like.

b. Man's tratment of the land.-Man's chief desire is to use the organic products of the land. He consumes the plant product. As a consequence, eultivated soils soon tend to become hard, lense, heavy and lifeless, and the more elay-like the land the more pronouneed is the result. 
The best and richest farm soils are those which are loamy-that is, those which are friable, soft and dark-colored. This loamy condition is brought about largely by the addition of stable-manures and green crops.

Every ordinary soil tends to lose its humus sooner than its mineral plant-food, and most so-called exhausted soils are injured in their physical condition rather than exhausted of their fertility.

It follows, therefore, that the addition of mere plant-food cannot entirely restore the generality of worn-out lands. The physical condition must always receive first attention. The addition of concentrated fertilizers is not a fundamental corrective of poor lands in the vast majority of eases. It should be considered as a supplement to the treatment of the land by means of tillage and cropping.

If man's reward from the cultivation of the land is so unlike nature's, it follows that one cannot eopy the practices of nature in the treatment of the land. Yet, in every generation, there are men who proclaim that because nature neither plows nor tills, therefore man should not. The only infallible guide to the proper treatment of the soil is experience, not mere science, nor speculation; but science explains the laws and directs the application of them when once experience has discovered them.

In fact, experience is law, for experience that persists is that which gives consecutively uniform results under like conditions. All experience proves that frequent tillage and the addition of humus quickly and invariably ameliorate and improve the soil. It is folly to attempt to controvert the facts by mere speculation. On the other hand, experience proves that the addition of chemical fertilizers does not invariably visibly benefit the soil; therefore, the value of such applications must depend upon local or transient eonditions.

c. The nursery lands.-The best nursery lands, at least in New York state, are those which contain much elay. This soil is the most easily injured by unwise or careless treatment and by the loss of organic matter. 
The nursery erop occupies the land for three to five years. During all this time the land receives no addition of organic matter, and finally even the roots are taken out of it. In very many cases the trees are planted and dug when the soil is wet or very dry, and, it is therefore, quickly and very seriously injured in its "grain," or its physical condition.

Nurserymen find that if the land is rested in clover or grass for a few years it will again grow trees. This rotation, like all others, is a means of ameliorating the physical condition of the soil as well as the ehemical condition of it. A part of the rotation must aim at the incorporation of humus. Therefore, every famous rotation has a "rest" crop in it.

An incidental advantage of any rotation is the variety of tillage imposed by it. A rotation of tools and of methods and seasons of working the land, is often as important as the other results of alternate cropping.

Extended figures of chemical analyses* of nursery stock show that the amounts of potash, phosphoric acid and nitrogen which such stock removes from the land is really very small, and less than that removed by similar bulk or weight of corn or wheat. Experiments now being made show that the addition of concentrated or chemical manures to heavy nursery lands does not promise very important results; but there are greater hopes from experiments in the sowing of erimson clover and other cover erops in the nursery rows, and in the use of stable manures. There are instances of excellent results following the addition of stable manure to nursery lands between the trees in the fall. One piece of land so treated has grown excellent plum trees for twenty consecutive years. There is no necessary reason why nursery stock should not follow nursery stock as well as wheat follow wheat, except that the land is usually more clay-like, the rotation or eropping is longer, and the addition of humus or fiber to the soil is less.

d. The conclusions. - The difficulty, then, is not one of amount

\footnotetext{
* Consult 10th Rep. N. Y. State Exp. Sta. (1891), and Bull. 103, Cornell
} Exp. Sta.; also Rep. Amer. Assoc. Nurserymen, 1896, 4:3-45. 
of plant-food so much as of the availability of that food by improving the physical conditions of the soil. The soil must be warm, soft, mellow, and the plant must be comfortable.

The trouble is, not that nursery trees take so mueh from the soil, but that the rotation is too long, the fiber is burned out of the soil, and much of the working of the land is untimely.

Certain lands are not readily injured by nursery cultivation, and these may grow several continuous erops of trees.

Now and then the nurseryman can augment the growth of "his stoek by extra attention to tillage (it is assumed that he always tills well), and by the addition of some quick nitrogen eompound, as nitrate of soda; but these are generally only temporary correctives. The complete or fundamental corrective for nursery land is rotation; but the length of this rotation may often be shortened, or even entirely reduced, by the judicious intercultural use of stable manures and cover erops.

The conclusion was made that the physical condition of the soil is a subject of greater or earlier importance than its chemical constitution; that the value of rotation of crops lies largely in its ameliorating effect upon the physical condition, and that nursery lands are no exception in demanding such rotation. Instead of thinking it strange that trees do not readily follow trees, we should rather think it strange if they did. Because the erop is of several years' duration, it becomes necessary that the alternating eropping should also be extended. A system of rotations must be practiced in blocks of years, not in single years. But this alternating eropping ean be greatly shortened by giving greater attention to the addition of fiber to the soil while the nursery stock is growing. There are instances in which the alternation may be made short, and some in which there need be hardly any. Professor Bailey said that he did not look for a general corrective of the depletion of nursery land, therefore, by the addition of concentrated or chemical fertilizers, but by better management of the lands. 


\section{COVER CROPS.}

A cover crop* is one which is used for the particular purpose of securing its mulching and physical effect upon the land in the intervals between the regular arops or the normal seasons of tillage. A sowed crop in the orchard may be valuable in two ways: by affording a cover to the land, and by improving the soil when it is plowed in. As a cover, it may keep down weeds, and protect the land from injurions effeets of frost. As a green manure, it may add fiber to the soil, and thus augment its power of holding fertility and moisture, and it may add directly to the fertility of the land. This late crop catches and holds the leaehing nitrates which the tree-roots ntilize earlier in the season. Taken as a whole, the cover crop may be said to improve the soil in eight ways:

I. It directly improves the physical eondition of the land:

Prevents hard soils from cementing or puddling ;

Holds the rains and snows until they have time to soak away into the land;

Dries out the soil in spring, making early tillage possible;

Sometimes serves as a proteetion from frost.

\footnotetext{
*Term first used in this connection in Bull. 61, Cornell Exp. Sta. 333 (Dee. 1893).
} 
II. It improves the chemical conditions of the soil: Catches and holds some of the leaching nitrates;

Adds humus;

Renders plant-foods available;

Appropriates nitrogen, if it is leguminous.

As a rule, crops grown for cover alone should be sown not earlier than midsummer. The most thorongh tillage can then be given early in the season, and the benefits of the cover can be secured for the early fall and winter. It is generally advisable to grow a crop which answers for both a cover and green manure, although it is easily possible to make the soil too nitrogenous for some fruits by the extravagant use of such fertilizers. It will also be observed, from the above enumeration of the benefits arising from cover crops, that crops which are killed by the winter may still be exceedingly useful. The reader must also be reminded, in passing, that much of the value of the cover crop depends upon its being plowed under very early in spring, as explained in the last chapter.

There is much confusion in the popular mind concerning the relation of cover crops to moisture. Some contend that any crop which shades the ground will keep the surface moist and conserve moisture, whilst others, knowing that all plants exhale water, consider that any crop tends to make the land dry. Both these opinions are partly correct. A erop which occupies the soil the entire season, and which does not allow of cultivation, will make the land 
dry, whilst one sowed late in the season upon land whieh has been thoronghly tilled during May, June and July, does not seriously rob the soil of moisture. At all events, there need be no fear of drying out the soil by sowing a late crop, for the serious injury of drought is usually effected before such crops are established, and rainfall is then becoming abundant; and the tree needs to be cheeked, rather than stimulated, at this season, by the transfer of the nitrates and moisture to other plants. The most marked way in which such erops eonserve moisture is by means of the fiber and humus which they impart to the soil when plowed under; but even this humus cannot compete with enltivation as a retainer of moisture.

An experiment at Cornell* illustrates the value of enltivation over a green crop occupying the land the entire season, in a dry year. The orchard is a hard clay, - just the soil whieh is benefited by the loosening effects of green manures. The orehard was divided into three portions in 1890 , a year after the trees were sot. One-third has reeeived liberal annual dressings of commercial fertilizers, and las been well tilled; another third has had no treatment except good tillage; and the remaining third has had liberal applications of potash, and has then been sown early to a nitrogenous (leguminous) green crop. This third portion has simply been plowed

*Bull. 72, Cornell Exp. Sta. This experiment has not yet progressed far enough for report upon methods of fertilizing, and is mentioned here only for the purpose of contrasting methods of cultivation. 
and fitted well each spring, and then sown, having received no subsequent tillage. The crops were all plowed under the following spring. The following are the crops :

1890. Mixed beans. Sowed June 16 .

1891. Field peas. Sowed June 24.

1892. Veteh. Sowed June 16.

1893. Cow peas. Sowed June 19.

1894. Field peas. Sowed June 14.

Here, then, is a chance to compare the effects of tillage with humus in a season of almost unprecedented drought. Upon September 1, 1894, the green inanured strip was much the driest portion of the orchard. The tree growth in this portion was much less vigorous, and the leaves were perceptibly lighter colored, than on the adjacent plots. Even the unfertilized but well tilled tract showed a better foliage. In this green manure portion, leaves on peach trees were then beginning to yellow and fall from the effects of drought, whilst the same rows, when they struck the other plots, showed perfect foliage. In apricots the effects were also marked. Pears and plums also showed the differences. In the cultivated portions one could easily stir up loose earth with the toe of his boot, while in the green manured part one had to dig from six to ten inches in a hard soil before he could find visible moisture. Careful tests showed the same fact. Samples of soil were taken to the depth of one foot on September 1, by means of a soil sampler, eight samples being lifted from representative parts of both the tilled and untilled areas. 
Four of these samples were combined into one, and this mixture constituted the eomplete sample which was used in a test for moisture; that is, there were two samples of untilled soil and two of tilled soil, but each of these was made up of four other samples selected from various parts of the areas. These samples were carefully weighed, and were then equally fire-dried and weighed again. The loss in weight represents the comparative content of free water in the different samples. The results are as follows:

$\begin{array}{lcc} & \text { Sample I. } & \text { Sample II. } \\ \text { Moisture in tilled soil, per cent........... } & 11.3 & 12.8 \\ \text { Moisture in untilled soil, per cent........ } & 8.7 & 9.6\end{array}$

In addition to this difference in moisture between the two areas, it should be said that in the tilled land it was distributed to within two inehes or less of the surface, while in the untilled land the first few inches was exceedingly dry. In other words, in the tilled land nearly the entire soil was in condition to part with its fertility, while in the other the uppermost and richest soil was inactive.

All this emphasizes the fact that tillage alone is better than green manuring alone; but the best results would no doubt have been obtained if good tillage had been given for two or three months, and if the green arop had been sown in July or August. In general, this combination is an excellent one for orehards, partieularly for sueh lands as lack nitrogen and vegetable matter, and for those fruits whieh are benefited by winter protection of the soil. 
The kinds of cover crops.-It will now be asked what is the best plant for cover and green manure. It is hard to tell. Clover is a stand-by, but it often fails to "catch" late in the season, and it should stand on the land an entire season in order to obtain its full value. Upon good and welltilled lands and in favorable seasons, considerable herbage can be obtained for turning under in the spring if it is sown the preceding August or September; but in general it is unreliable as an annual crop, and is not adapted to fruit lands.

It should be said at the ontset that the choice of the proper crop for the covering of an orchard is a local matter, the same as the determination of the method of tillage or the kind of fertilizer is. There is also no one cover erop which is best for all purposes and all conditions. The grower must study the condition of his trees and his land, and then judge as best he may what course he shall pursue. Nature's cover crops, at least upon farms, are weeds, and these may be useful if allowed to grow in the fall after the tillage is completed. The difficulty is that they eannot always be relied upon to cover the land at the time when they are wanted, most of them do not live through the winter, and they are very likely to become a serious nuisance. It is best, therefore, to substitute some other plant for the weeds. In approaching the question of the choice of cover crops, the grower must remember that there are two great classes in respect to their power to gather nitrogen. The one class is non- 
leguminous, comprising those plants which take only such nitrogen as has already been worked over into available form by plants or animals; the other class is the leguminous plants, comprising those which have the power of appropriating and utilizing free nitrogen. For purposes of cover and protection, the non-leguminous crops may be just as good as the nitrogengatherers, and when the fruit plants are growing very vigorously they may be decidedly better than the others becanse, by not adding nitrogen, they do not over-stimulate the growth. A rotation of cover crops will nearly always be found to be important. It is perfectly possible to put so much nitrogen into the land that the trees or plants grow too vigorously or too late in the season. This may be especially apparent upon peaches, apricots, grapes, and the like. It should also be said that some of the most useful of these cover crops will not thrive upon hard and intractable land, and in such cases a rougher and coarser crop nust be used.

The golden seale of cover crops for orchards begins with rye and ends with erimson clover. Lands which are very sandy and leachy, as well as those which are hard and lumpy, are usually not adapted to the growth of crimson clover, especially in the north. Such lands must be gradually ameliorated by the use of other plants, and, as a rule, the best plant to begin with is rye. This plant thrives upon a great variety of soils, it demands little preparation of the land, the seeds are large and germinate at a low temperature, it can be sown late in the season after 
cultivated crops are removed, and it is exceedingly hardy. Rye may be sown upon the very moment of the freezing up of the land, and it will sometimes germinate the following spring. It is ordinarily best, however, to sow it about a month or six weeks before the land is expected to freeze up; and for the purpose of securing a cover, not less than one and one-half bushels should be sown to the acre when orchards are young. When the trees have begun to shade the ground, a less quantity will answer.

Another plant which is sometimes used to begin the amelioration of intractable lands is Indian corn, sown broadeast very thickly, six weeks or two months before killing frost. Although it does not stand the winter, it nevertheless affords an excellent cover for the land and supplies besides a large amount of herbage.

Buckwheat may be used for the same purpose, sown so late in the season that it will reach its full height but will not go to seed. There is danger, however, of using buckwheat too much, and only an oceasional crop of it-if any at all-should be used upon orchards which are growing upon the hard types of lands.

Turnips and rape are also to be recommended in certain cases. Turnips sown late in July in the north make a complete cover of the land, and furnish so much bulk and moisture as to greatly improve the character of the soil when they are plowed under the following spring. Turnips are especially good to begin the process of improve- 
ment upon certain hard lands which are much inclined to be dry.

Oats, wheat, barley, millet, and various other quick-growing crops may be ntilized as covers, but they are less adapted to the purpose than those which have been mentioned. In order to impress the different qualities of cover erops upon the mind, it may be well to say that rye and corn, and the like, are to cover crops what pigs and mules are to domestie animals.

Amongst the leguminous erops are the various kinds of peas, beans, vetches, and the clovers. If it is desired to grow a leguminous crop upon land which is hard and dry, it will be necessary to choose those with large and quick-germinating seeds, like the beans and the field peas. Common field beans may be sown broadcast late in the season, and if they can have six weeks of uninterrupted growth, will make a good cover before killed by frost. Canada peas are not injured by the early frosts of fall, and therefore may be sown later. At the Cornell Station, peas sown as late as the 20th of September reached a height of about six inches, and were large enough to afford a fairly good cover, if they were sown very thick. But, in general, in the northern states, it is adrisable to sow not later than the last of August or the first of September.

The cow pea (Vigna Sinensis) can often be used to the greatest advantage, espeeially in the middle and sonthern states, where the long seasons allow 
it to make a most luxuriant and satisfactory growth. In fact, it is probably destined to fill the office in the southern states that the red clover does in the north, and, if properly used, can, no doubt, be made the means of filling the burned-out soils of the south with fresh life and vigor. It is killed by the earliest frost, and is, therefore, not advisable at the north, unless sown early or upon land which is in good condition, so that it may obtain a quick start. Experiments with this plant have been made at the Cornell Station,* with the following results: "Sixteen varieties were grown at the Station this year [1893] for the purpose of ascertaining which ones will mature in this latitude; and over half an acre was sown to the Black pea, which Professor Massey, of North Carolina, thought likely to prove the best variety for our purpose. These black peas were obtained of L. R. Wyatt, Raleigh, N. C., and were sown June 20. The land was clay, and variable in contour, comprising two dryish knolls, with a moist vale lying between them. The peas were slow in starting, owing to the hard soil, but they made a fair growth in August and early September. In the vale, the plants grew nearly two feet high and covered the ground well, but on the knolls the soil was not covered. The plants had just begun to flower when they were killed by the first frost. The leaves fell off, and the bare, stiff stems now afford very little protection to the soil.

*Bull. 61, Cornell Exp. Sta., 334. 
"The varieties of cow peas, grown for the purpose of ascertaining the earliness of the various kinds, were sown May 31, in rich garden loam. These peas were obtained from the Experiment Stations of North Carolina, Arkansas and Louisiana. The varieties ripening seeds are ten, as follows:

Black, from North Carolina.

Black Eye, North Carolina.

Blue, Louisiana.

California Bird's Eye, Arkansas (Dolichos sesquipedalis).

Clay, North Carolina.

Gray Prolific, North Carolina.

Large White, Lonisiana.

Whippoorwill, North Carolina, Arkansas, Louisiana.

Yellow Prolifie, North Carolina.

Yellow Sugar Chowder, Arkansas.

"The varieties which did not mature seeds are the following:

Black, from Louisiana.

Brown Eye, Arkansas.

Clay, Louisiana.

Conch, North Carolina.

Indian, Lonisiana.

King, Louisiana.

Lady, Louisiana.

Purple Hull, Lonisiana.

Stewart, North Carolina.

"The varieties which seemed best adapted to this 
latitude were the Black and Whippoorwill. The latter fruited also at Lansing, Michigan, in 1887. It will be seen that there appears to be a difference between samples of the same variety coming from different sources. The Black pea from North Carolina seed matured well, but that from Louisiana stock was too late. The same difference oceurred in the Clay. This is what might have been expected, and it emphasizes the importance of securing seed from the northernmost station, when choosing stock for growing in the north. On the whole, the Black cow pea seems best adapted to growing in central New York. A small patch of this was sown on a rich, loose soil July 17, and the plants made as heavy growth as those sown upon the clay soil nearly a month earlier. But the cow pea affords so much less winter protection to the soil than the vetch, without any counterbalancing advantages, that it can scarcely be recommended for an orchard cover in the north." Upon mellower and moister lands, however, good results have frequently been obtained with cow peas in the northern states, and they are growing in favor.

The use of the vetch or tare as a cover plant was brought forward by the Cornell Station,* and reported upon in 1892, as follows: "Orchard lands are nearly always benefited by some cover or mulch during a part of the year, especially during fall and winter. One of the values of sod lies in the protection to the soil, but a sod cannot be obtained

*Bull. 49, Cornell Exp. Sta., 1892. 


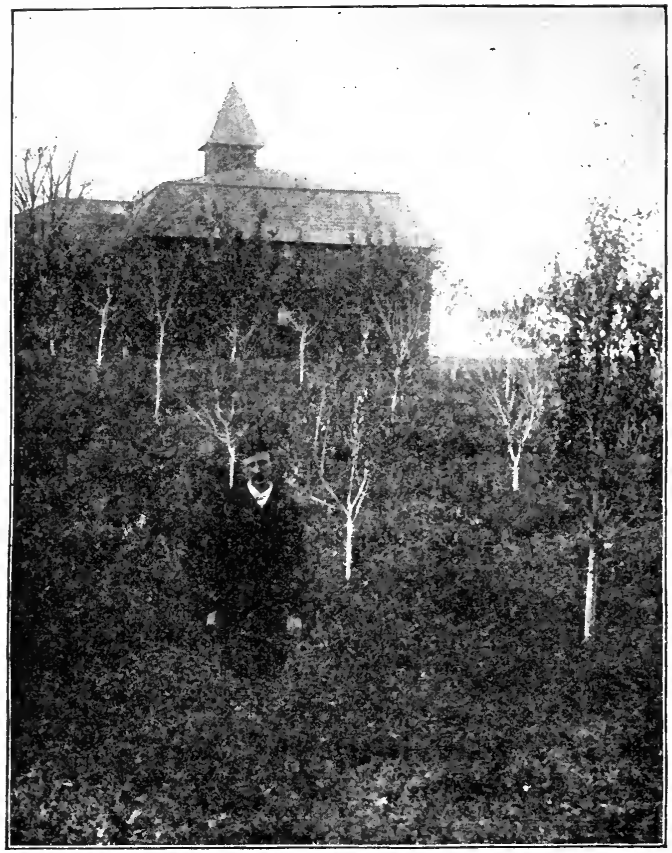

Fig. 20. A good stand of vetrh, in November. Sown in early July.

in a single season. If orehards can be coltivated in spring and early summer, and then protected with some growth which will shade the soil and keep 
it moist during the remainder of the warm weather, and afford some protection from frost during winter, the best results will undoubtedly be obtained, as a rule. This cover crop should also afford fertilizing materials to the soil when turned under, and greatly improve the mechanical character of the soil as well.

"The leguminous plants - those belonging to the clover family - at once suggest themselves, because they are rich in nitrogen, and may therefore serve both as cover and fertilizer. We have tried mixed beans and field peas, but there are objections to both, although either one is probably better than weeds or bare ground. This year we have tried the European vetch or tare (Vicia sativa), seed of which we obtained of J. M. Thorburn \& Co., New York. This plant is grown for forage in England. A half bushel of seed was sown June 16 upon five-eighths of an acre of heavy clay loam. It was sown broadcast npon a freshly prepared surface, and well dragged in. The seed could have been sown later with equally as good effect, no doubt, and the cultivation of the orchard could have been continued for ten days or two weeks longer. The young trees of pear, plum and apricot have made an excellent growth this year among the vetch. The vetch started somewhat slowly, and the seeding seemed to have been too thin; but by the middle of September the ground was covered thickly. Frost came October 1, but the vetch was not injured, and it continued to grow until the middle of the month, and remained green still longer. It made a 
remarkable cover, growing knee-high in a dense mat, and everywhere completely covering the ground. It began to flower in September, but no seeds ripened except upon a few poor spots. Upon light soils, seeds would probably form freely, but the plant is an annual, and is not likely to beeome a weed. The roots do not extend deep. With the approach of hard freezing weather, the stalks fell upon the ground, where they now lie like a thin, even covering of old hay. The stems are soft, and ean be easily plowed under in spring, and will soon decompose; and they will not keep the soil wet too late in spring, which is an important point upon elay soils."

The following year a second report was made upon it: "The vetch is an annual leguminons plant, which continues its growth long after frost, and which mats down with the snow into a perfeet, carpet-like covering. In the spring, the vines are so well decayed that the cover can be plowed under easily. The veteh can be sown late in June or early in July in this state, and the plants will eover the ground with a dense tangled mulch two feet deep when winter sets in. Last year (1892), we sowed the vetch June 16 . This year we sowed one area June 20, and another June 28. Both made an ideal mulch, and the plants were green and still growing late in November. They produced no seeds, and but very few flowers. About a bushel of seed should be sown to the acre. The seed is large and germinates readily, and is likely to eatch at 
almost any time during the summer. Some idea of the dense growth of the veteh this year may be obtained when I say that one patch overeame and obscured a heavy growth of horse-radish which had been in the ground two years. I am confident that upon fairly good soil, good results ean be obtained with veteh sown as late as the middle and possibly the last of July."

Crimson or scarlet clover was bronght emplatically to the fore as a cover plant for orchards by the Delaware Experiment Station* in 1892. It has been the occasion of much speculation and much misunderstanding. Like other novelties, it has been hailed by some as a plant which is bound to revolutionize orchard management and to make plantations productive; and others, who have failed, have discouraged its use entirely. The fact is, as already pointed out, that erimson clover is only one step or round in the ladder of cover crops, and it is ordinarily the last and the highest. By this it is meant that it will not thrive upon hard or poorly tilled land. It must be sown in midsummer or a trifle after, when the ground is likely to be dry. The seeds are small and oily, and the grower is very likely to fail in securing a "catch." Upon the better tilled lands, however, erimson elover may be expected to succeed as often as any other plant of its elass will. People have also made a mistake in expecting too heavy a growth of herbage in the erimson clover. It is an annual plant, normally completing its entire

* Bull. 16, Del. Exp. Sta., March, 1892. 


\section{of Fruit-grouing.}

growth in a single season. When sown at midseason, therefore, it should not be expeeted to yield a very heavy erop. If it should arrive at that stage when it nearly or wholly eovers the surface of the ground with a thin, close mat, it will have reached its most profitable condition. Neither is it necessary that the plant should stand the winter and grow in the spring. Turnips, maize, veteh, and other tender plants are known to be very useful as orchard cov-

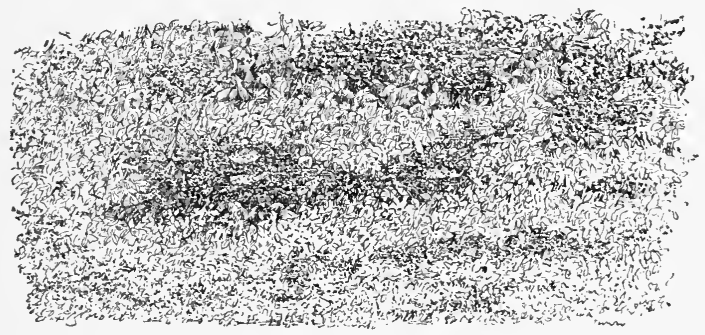

Fig. 21. A good staud of erimson clover as it looks before growth has begun in the spring.

ers, although they pass the winter in the dead state. If the erimson elover passes the winter and grows in the spring, much will be gained; but if it should not pass the winter, nothing will be lost. In respeet to the proper time for sowing erimson clover, it may be said that if it is sown very early in the season (that is, before the first of July), it is likely to become too large and ripe, and be killed by the winter; if it is sown too late (that is, after the middle 
of August in the north), it will ordinarily not attain sufficient foothold to be able to withstand the heaving by frost. Crimson clover may be sown amongst Indian cor'u at the last cultivation, but in orchards it is ordinarily sown from the middle of July to the middle of August in the north, upon a well prepared seed-bed, and is then lightly dragged in. In old orchards, six quarts to the acre is a sufficient amount of seed; in open lands, about eight quarts are required.

The following analyses show the fertilizer values of the various leguminous plants here discussed. The vetches and peas were analyzed at the Cornell Station. The analysis of cow peas is taken mostly from Professor Teller's recent studies in Arkansas, those of clovers from reliable sources for comparison:

\section{VETCH, READY TO BLOOM, ROOTS AND TOPS.}

Original substance. Dry substanee.

Nitrogen .............. .65 per cent. 3.1 per cent.

Phosphoric acid .......... . 146 "

Potash ................. $\quad .475$ " "

Water.................. 79.15

PEAS, 2 TO 3 FEET HIGH, NO FLOWERS, ROOTS AND TOPS. Original substance. Dry substance.

Nitrogen ............... .451 per cent. 2.33 per cent.

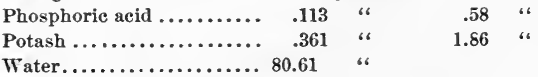

PEAS, 6 INCHES HIGH, ROOTS AND TOPS.

Original substance. Dry Substance.

Nitrogen ............... .34 per cent. 2.43 per cent.

Phosphoric acid .......... . .086 " "

Potash ................ . 179 " "

Water................. 86.05 
COW PEAS (WHIPPOORWILL) IN BLOSSOM, STRAW ONLY.

Original substance. Dry substance.

Nitrogen ............. .618 per cent. 3.09 per cent.

Phosphoric aeid ......... . . "6

Potash .............. . . 396 "

Water................ 80 .

RED CLOVER-AVERAgE OF SEVERAL ANALYSES.

Original substance. Dry substance.

Nitrogen............... .41 per cent. 2.05 per cent.

Phosphoric acid.......... . . " " "6

Potash................ .45 " "

Water................ "

CRIMSON CLOVER (TRIFOLIUM INCARNATUM).

Original substance. Dry substance.

Nitrogen............... .43 per cent. 2.45 per cent.

Phosphoric acid.......... . 13 " "

Potash................ .49 "

Water................... "

FERTILIZING THE FRUIT PLANTATION.

Having now discussed how, by tillage and cover crops, the land may be made fit for the growing of fruit plants, we come to the question of what plant-foods may be added to the soil. It should first be said that fruit plants use up plant-foods

Note. The following figures show the approximate quantities of seed which are recommended per acre for cover erops in young orchards :

Barley............... 2 to $2 \frac{1}{2}$ bus.

Beans ................. 11/2 to 2

Buckwheat................... $]^{\text {" }}$

Clover, erimson......... 8 to $16 \mathrm{lbs}$.

- red

6 to 12

Corn................. $2 \frac{1}{2}$ to 3 bus.

Cow pea.....................
Millet .............. 1 to $1 \frac{1}{2}$ bus.

Oats................ 21/2 to 3 "

Pea.................... 2 to 3 "

Rye................. 11/2 to $2 \frac{1}{2}$ "

Turnip ............... 3 to 4 lbs.

Vetch .................... 1 bus.

Wheat................ 2 to $2 \frac{1}{2}$ " 
the same as other erops, and yet the common neglect of orchards seems to show that many people think otherwise, or else do not think at all. In fact, the depletion of the land by fruit trees is more serious than by annual crops, from the fact that plantfoods are locked up for many years in the trunks and branches of the trees, whilst a large part of the fertilizing constituents in common crops returns to the soil each year. On the other hand, it should be said that the roots of trees have a larger foraging area than the roots of small crops do. This is well shown in Figs. 17 and 18 (pages 160 and 162). The former shows the roots running far away in the poorly tilled soil in search of food, and the latter shows the home-staying roots in the rich soil.

Roberts has computed,* from analyses, the values of nitrogen, phosphoric acid and potash taken from an acre by apple trees (the trees thirty-five feet apart) in twenty years, counting in ten crops of fruit :

Value.

"Total in fruit for twenty years................ \$147.00

Total in leaves for twenty years............... 160.51

Total in wood for life of tree................ 70.00

Grand total....................... $\overline{\$ 377.51}$

"The value of nitrogen, ete., in any given case is so indefinite and variable that stress should not be laid on values as given above, but on the total amounts of plant-food used by the orchard.

*Bull. 103, Cornell Exp. Station. 
"The total amount of nitrogen, exclusive of that used in the growth of the trees, is 1,336.8 pounds, of phosphoric acid 310 pounds, and of potash 1,895.4 pounds. To restore the potash alone, as above, and that used by the growth of the tree, it would require 21.69 tons of high-grade ashes containing 5 per cent of potash. To restore the nitrogen as above, would require 16.19 tons per acre of a commercial fertilizer containing 5 per cent of nitrogen.

"How much of this plant-food is usually furnished to the orehard by leguminous plants and by feeding supplementary foods to animals which graze upon it, and how much by the fallen leaves and apples which are not blown or earried off, cannot be told.

"While some of the computations and conclusions are based on estimates, yet it is believed that the tables represent average conditions, and need only the good judgment of the observant reader to make them apply to his individual case with such degree of accuracy as to give valuable aid in the care and feeding of orchards.

"Many old orehards have not only been making these large demands on the soil for the last twenty years, but in many instances the land has been used for the production of hay or grain, or more frequently for the growing of lambs or pigs, with little or no supplementary food. The grazing of orchards, especially with growing animals without extra food, is as certain to deplete the land as grain raising, though the soil robbery is not so rapid. 
"These investigations, when considered in all their bearings, lead one to wonder not why old orchards are failing, but why they have not ceased to produce merchantable fruit long since."

Another calculation by the same investigator shows the amount of plant-food which may be expected to be carried away in the fruit, and blown off in the leaves (not computing the amount in the wood), for the period between the ages of 13 and 33 years of apple trees :

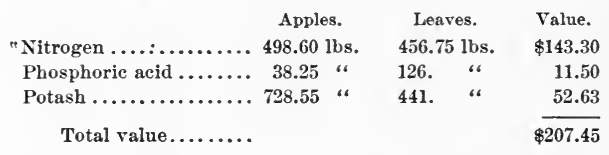

"While the above results are reached by assuming a given amount of apples and leaves per year in a bearing orchard, and while the facts in any given ease at any given time may vary widely, yet it is believed that they are valuable, as they furnish a means of measuring in any given case, with a great degree of accuracy, the amount of soil exhaustion."

He also "shows that an average crop of apples removes in round numbers eleven pounds of nitrogen, nearly one pound of phosphoric acid and sixteen pounds of potash, and that the leaves of a tree large enough to produce the apples would contain ten pounds of nitrogen, nearly three pounds of phosphoric acid and ten pounds of potash, or a total 
of twenty-one pounds nitrogen, three pounds phosphoric acid, twenty-six pounds potash."

"As a clearer comprehension is had by comparing unfamiliar things with familiar things, a table follows which gives in brief the soil exhaustion which is likely to oceur from a continuous twenty-year wheat production. Here, again, an average yield has been assumed which, while approximately correct for New York, may be wide of the mark in some states where the average yield of wheat falls to eight or ten bushels per aere.

"The following tables show the amounts and values of the fertilizing ingredients removed by wheat (grain and straw) in twenty years' continuous cropping, assuming an average yield of fifteen bushels per acre and seven pounds of straw to three pounds of grain:

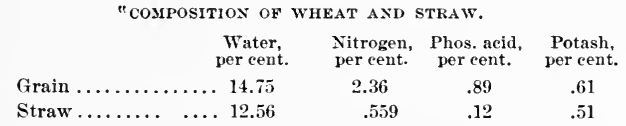

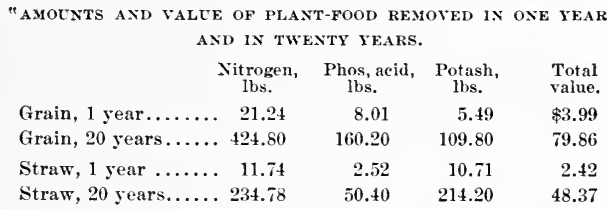

Total value in wheat, grain and straw for 20 years. $\$ 128.23$ Total value in apple, fruit and leares for 20 years.. 207.45

"The above table shows that the orchard requires, 
if fruitful, plant-food equal in value to about eighty dollars more than the wheat. No one would think for a moment of trying to raise wheat, even on our best New York land, for twenty consecutive years, even though the soil was fitted in the best possible manner yearly."

Respecting the need of fertilizers for orchards, Voorhees writes as follows:* "It is argued by many, and sometimes by those who should know better, that fruit-growing is quite similar to growing trees; that the question of soil exhaustion is not a matter of very great importance, provided the soil is well cultivated, and that all soils contain sufficient quantities of the food elements to insure the relatively small available "supply required from year to year.

"It is admitted that on soils of good mechanical condition, well drained and cultivated, which are naturally adapted for fruit as well as other crops, because well supplied with the essential constituentsnitrogen, phosphoric acid, potash, and lime-the exhaustion arising from the continuous removal of crops will not become apparent for a long time, but it should be emphasized that it is only upon soils which possess these characteristics that the growth of fruit, even poor fruit, can be continued for any considerable period without the application of manures."

"It is obvious that such specific results as have been obtained concerning the needs of general farm 1896.

*E. B. Voorhees, "Manuring Orchards", before Mass. Hort. Soe. Mar. 28, 
crops, as grain and grass, for specific plant-food elements, eannot be applied with any degree of accuracy to fruit crops, particularly the larger fruits, as pears, apples, peaches, grapes, and plums, beeause these differ from the cereals, grasses, and regetables, first, in their habits of growth, seeond, in the character of the produee, and third, in their relation to soil exhaustion.

"In the first place, farm crops, as a rule, require but one year for the entire processes of vegetation and maturation. For fruit erops, with but few exceptions, the purely vegetative processes eontinue for at least three rears, and with many kinds much longer, while after the fruit-bearing period begins the vegetative processes do not cease, but are coincident with the growth and ripening of the fruit. In the second place, the product of the harvest, namely, the fruit, differs very materially in its eharaeter from that of ordinary farm erops, which mature their fruit and die in one season, because a whole season is required for its growth and development; that is, it is necessary that there shall be a constant transfer of the nutritive juices from the tree to the fruit throughout the entire growing season, while the growth for each suceeeding year of both tree and fruit is dependent upon the nutrition acquired and stored up in buds and branches, as well as upon that which may be derived directly from the soil. In the third place, the relation of fruit-growing to soil exhaustion is very different from that in general-crop farming, beeause in orchards there is an annual de- 
mand for specific kinds and proportions of soil constituents; it is really a continuous cropping of the same kind; there is no opportunity, as in the case of ordinary farm crops, to correct the tendency to exhaustion by a frequent change of crops, or the frequent growth of those which require different kinds and amounts of plant-food constituents.

"In studying methods of manuring orchards, however, it must be admitted that the general principles of manuring which apply to fruits apply quite as well to farm crops; that is, the essential constituents of manures must be the same. A fruit tree will not make normal growth in a soil destitute of nitrogen. That nitrogen encourages leaf-growth is a recognized fact, and, since trees grow by means of both leaf and root, its presence is required in the soil in order to promote the growth and extend the life of the tree. It is very evident, too, that potash is an essential constituent in the growth of fruits, not only because it constitutes a large proportion of the ash of the wood of the apple, pear, cherry, and plum, and more than 50 per cent of the ash of fruit, but because it forms the base of the well-known fruit acids; and in order to nourish a tree properly, as well as to insure proper ripening, phosphoric acid is also very essential, though it is apparent from such investigations as have been made that this constituent is relatively of less importance than for the cereals.

"It is also a matter of common observation that, in the production of stone-fruits particularly, lime 
is an important constituent. Its function seems to be to strengthen the stems and woody portion of the tree, to shorten the period of growth, and to hasten the time of ripening. Fruit trees growing on soils rich in lime show a stocky, steady, vigorous growth, and the fruit ripens well, while those on soils which contain but little lime, particularly the clays, appear to have an extended period of growth, the result of which is, that the wood does not mature and the fruit does not ripen properly."

Voorhees also reports* an experiment in the fertilizing of peaches, showing large gains in crop from the separate use of stable manure and fertilizer. "It is interesting to observe," he writes - "and it is a point of great importance-the effect of an abundance of food in overeoming unfavorable weather or seasonal conditions. The year 1889 was extremely unfavorable, and the crop throughout the state [New Jersey] was small. In this experiment the ummamured plot yielded at the rate of ten and nine-tentlis baskets per acre, while the manured and fertilized plots both showed a yield exeeeding one hundred and fifty baskets per aere. The manure strengthened and stimulated the trees, and enabled them sueeessfully to resist such eonditions as were fatal to the erop on the numanured land. This point is one that is seldom eonsidered in ealenlating the advantages to be derived from proper manuring, though it is of extreme value, sinee the expenses of cultivation, trim-

*See, also, Repts. N. J. Exp. Sta., 1884-1894. 
ming, and interest on investment are quite as great in one case as in the other."

Stable manure.-The kinds of fertilizing applica. tions are of two types, stable manures and concentrated or commercial plant-foods. The stable manures exereise a most important effect upon the physical features of the soil, and, in fact, this is often their greatest value. In this respect, stable manures may answer much the same purpose as green or cover crops, particularly if they are applied in fall or early winter. When manure is not sufficient to cover the entire plantation, it should be applied to the hardest and driest spots only, and these spots should be observed and noted the previous season. Lands which are so hard or dry that even rye will not eatch, may be got under way for the cover crops by liberal applications of barn manures. Rotation in the use of fertilizers may be found to be as useful as it is in the case of cover crops. A soil which has had a liberal application of stable manure one year, may profit more by some chemical fertilizer the next year.

In orchards which are thoroughly tilled, the use of barn manures should sometimes be discouraged, for the chief element of fertility in them-if they are not leached-is usually nitrogen. This advice is particularly applicable to vineyards, and all other fruits which run very strongly to wood. In such cases, it is better economy to apply the manures to the annual crops of the farm. The old, neglected apple orchards of the country, however, may receive 
barn manures with safety; yet, even here it is a question if economy would not dietate tillage and late green manures to supply the nitrogen, except. perhaps, for a season or two when an attempt is making to rejuvenate an orchard. Mnlehing a sod orchard with manure often gives fairly good results in cases in which the land eannot be cultivated; but better results in the way of fertilizing and in freedom from weeds and insects ean be obtained by pasturing closely with sheep or swine.

Chemical fertilizers. - Nitrogen, potassium and phosphorus are the elements which need to be applied to orehard lands; and to these should sometimes be added lime, mostly for its secondary effects upon the soil.

Nitrogen is particularly efficacious in promoting growth. "The general tendency of nitrogenous manures is toward the excessive production of wood and foliage," writes E. F. Smith, after having made many explieit experiments npon peach trees.* In fact, the amount of growth and the color of foliage are reliable guides for the application of nitrogen. When mature or bearing trees make a foot or more of growth upon all shoots, and when the leaves are of good size and dark color, the orehard probably has enough nitrogen. A free application of nitrogen to such orehards might do more harm than good, in promoting growth at the expense of fruit, or, in the ease of some stone frnits, in pro-

* Bull. 9, Section of Veg. Path., Botanieal Div. U. S. Dept. Agr., 142. 
ducing a poorly matured growth, which will be likely to suffer in winter. Orchards are grown for fruit, not for forestry purposes. In general, it is better to supply nitrogen by good cultivation-which assists nitrification-and an occasional green-manure erop, than by the application of nitrogenous fertilizers. If the orchard is not growing, and is yellowish in fóliage, good cultivation-begun early and repeated very frequently-in connection with the use of potash, phosphoric acid and green manures, will com. monly correct it. It is probable that lack of moisture is quite as much the cause of the weakness as lack of nitrogen, particularly if the orchard has been in sod. Now and then a tree will be found which fails to respond to ordinary treatment. If the tree is healthy-that is, not attacked by disease or borers-it may sometimes be brought into a vigorous condition by applying to it a light dressing of nitrate of soda; but this treatment need seldom be applied to an entire orchard which has been well handled.

An experiment made by the Cornell Station (Bulletin No. 153) gave very decided results from the use of nitrate of soda alone. An apple orchard about twenty-five years old and unproductive, standing upon a rather hard and dryish light clay loam, was plowed in the fall of 1894, and certain trees were given an application of ten pounds of nitrate of soda. Contiguous rows received heavy applications of sulfate of potash and muriate of potash. All materials were applied August 11, 1894. The or- 
chard was plowed again in the fall of 1895, and a third time in the spring of 1896 . None of the dressings showed any effect in 1895 , but in 1896 the trees which had received the nitrate of soda were very remarkably supeior to those which had received the other treatments and to those which had received none. They had very much heavier and darker green foliage, so that they conld be readily distinguished many rods away, and they had a heavier load of fruit, which was larger and finer than that upon the other trees. This heavier crop was probably not due to more profuse blossoming, but to a less dropping of young apples. In 1897, the trees still showed the effect of the nitrogen. In 1898, all effects were lost, and the trees and fruits could not be distinguished from those which were untreated.

Nitrogen-fertilizing often exerts a decided influence in delaying the maturity of fruit, and it is worth while to consider the application of such fertilizers to winter apples which tend to ripen too early. These fertilizers also tend to the production of low colors in fruit. Lodeman found, $*$ as the result of experiment, that "the apples produced upon the plot which was, in all probability, the richest in nitrogen, were late, and they were also poorly colored."

Potash is generally the most important element to be applied directly to orchards, particularly after

\footnotetext{
* Rural New-Yorker, Jan. 2, 1897, 2.
} 
the trees have reached bearing age. The store of available potash in the soil is much increased by the thorough tillage which has already been recommended, but in bearing orchards it should also be supplied every year in some commercial form. One of the best sources of potash for orchards is wood ashes, but this material is "so often weakened by leaching that it cannot be confidently recommended. A good sample of unleached hard wood ashes should contain from 5 to 9 per cent of potash, but some of the commercial article does not analyze above 2 to 3 per cent. Potash in this form has a trade value of $4 \frac{1}{2}$ cents per pound. To this value of wood ashes should also be added 2 per cent or less of phosphoric acid, now worth 6 cents a pound. Forty to fifty bushels to the acre is considered to be a good dressing of wood ashes, if it has been kept dry.

Muriate of potash is perhaps the best and most reliable form in which to secure potash at the present time for fruits. Commercial samples generally contain from 80 to 85 per cent of muriate of potash, or about 50 per cent of actual potash. Kainit is an impure muriate of potash, containing about 12 to 15 per cent of potash. An apple orchard in full bearing and upon loose soil may receive as high as one thousand pounds of muriate of potash per acre, but a normal and economical application is from one hundred and fifty to three hundred pounds, if applied every year. Sulfate of potash is also thought to be a good form in which 
to buy potash. The commercial article analyzes 50 per went or less of actual potash. Sylvinit is a lower grade of potassium fertilizer. Its value-like that of other materials mentioned-should be reckoned upon the amount of potash present.

Phosphorie acid may be obtained in the form of a high-grade plain superphosphate (like dissolved South Carolina rock), in bone compounds, and Thomas slag. The plain superphosphate contains abont 16 or 18 per cent of phosphoric acid, and two hundred to five hundred pounds per acre is a liberal and rery useful dressing for bearing orchards. The bone fertilizers are always valuable. Those which are untreated give up their phosphoric acid slowly, unless they are very finely ground. Dissolved bone gives more immediate results. Thomas or basie slag, which is yet less known to farmers in this comtry, has given good results in many tests, but it parts with its fertility rery slowly. It is yet too early to recommend this material for orchards with full confidence.

In general, phosphorie acid is probably less important in fruit plantations than potash, although this order is reversed in general farming. Potash should undoultedly be the leading factor in orchard fertilizers, and nitrogen may be obtained largely, or even wholly, in some cases, by means of tillage and green crops. It will then be seen that the use of combined or "complete" commercial fertilizers may" not be economical. The best results are to be expected when the fruit-grower observes closely the 
behavior of his trees and then applies such materials as the plants appear to need. Any of the materials mentioned in the foregoing remarks may be mixed together, so that the phosphorus and potassium can be applied at the same sowing. It should be said, however, that if wood ashes is mixed with

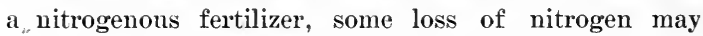
ensue, unless the material is used at once.*

Voorhees givest the following "practical suggestions" for the fertilizing of orchards: "A system of manuring for cultivated orchards, based upon the limited data at our disposal, may be outlined as follows :

"To provide vegetable matter and to improve the physical quality of poor soils, apply yard manure once in four years, in fall or winter, at the rate of from five to ten tons per acre. To aid in the decomposition of vegetable matter, and to insure a

\footnotetext{
* To answer inquiries concerning the prices of fertilizing materials, it may be said that muriate of potash costs $\$ 40$ and upwards per ton, sulfate about $\$ 18$, dissolved boneblack about $\$ 24$, ground bone about $\$ 30$, kainit about $\$ 13$, and nitrate of soda $2 \frac{1}{4}$ cents per pound. These prices vary, of course, with the composition or mechanical condition of the materials. The average composition of unleached ashes in the market is about as follows: Potash, 5.25 per cent; phosphoric acid, 1.70 per cent; lime, 34 per cent ; magnesia, 3.40 per cent. The average composition of kainit is 13.54 per cent potash, 1.15 per cent lime. The composition of sylvinit (which is said to be known as sulfate of potash in some quarters) is about 16 per cent of potash, in the form of both muriate and sulfate, mostly the former. The fact that the soil itself is the greatest storehonse of plant-food is shown by the following average of thirty-five analyses of the total content of the first eight inches of surface soils, per acre: 3,521 pounds of nitrogen, 4,400 pounds of phosphorie acid, 19,836 pounds of potash. Much of this is nnavailable, but the good tillage and cover cropping which have been recommended tend to unlock it.
}

t E. B. Voorhees, address before Mass. Hort. Soc. Mar. 28, 1896. 
sufficiency of lime as plant-food, apply lime at the rate of twenty-five bushels per acre once in five rears. To provide, in addition, an abundance of all forms of available plant-food at the times needed for the development of the tree and fruit, apply annually chemieal fertilizers in the following proportions :

"Nitrate of soda.......................... $100 \mathrm{lbs}$.

South Carolina rock superphosphate............ 100 “"

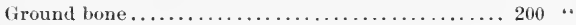

Muriate of potash......................... 200 “

"The amounts to be applied depend upon the charaeter of the soils, as previously outlined, the kind of fruit, and the age and vigor of the tree; these given perhaps mark the minimum.

"In a number of best orchards the quantities applied are very much larger than is here indicated, and the larger application is believed by the growers to be proportionately profitable.

"By the recent introduction of crimson elover, we have a plant admirably adapted to supply cheaply nitrogenous vegetable matter for orehards, and its growth is to be recommended wherever the plant can be suecessfully grown, instead of the use of barnyard manure, particularly upon the poorest soils, until they are abundantly supplied with vegetable matter. The clover should be plowed down early in the season, in order not to retard the spring growth of the trees. Where the conditions are favorable for the growth of elover, the application of nitrate. of soda may be omitted." 
Summary statement.-The fruit-grower will no doubt desire to ask how he is to tell just what kind and what quantity of fertilizers to apply to his land. This is one of those questions which no person can answer for him. Having studied the matter carefully, and having observed lis plantation from day to day and year to year, he should be able to discover about the treatment which it needs. As a general statement, it may be said that the fruit plantation which is giving satisfactory results is receiving the very treatment which it needs; but when it is giving unsatisfactory yields, some change in the management should be made. An orchard which is in sod and not doing well should certainly be plowed and tilled. One which is tilled and is not doing well may be benefited by seeding down, or it may not. If the growth is strong and rapid, and the trees or vines seem to be going to wood at the expense of fruit, then some check may be necessary. This check may be given by seeding down for a time, by giving somewhat less thorough or prolonged cultivation, or by the use of rather more mineral fertilizers and less nitrogenous ones. In all cases in which the growth is not sufficient and the leaves are yellow and drop early, it is probable that either more nitrogen or more moisture, or both, is needed. As a general principle, it may be said that nitrogen ean be had in sufficient amount by thorough and judicious tillage, by the use of leguminous cover erops, and by stable manure. In some cases, however, quicker and cheaper results may be had by 
the direct addition of nitrogenous materials, like nitrate of soda, sulfate of ammonia, or some of the animal compounds.

The grower should also remember that the plants need all the elements of plant growth, and not one of them alone. For example, a heavy application of nitrogen upon soil which is deficient in potash and phosphoric acid cannot be expected to give useful results. In the same way, the application of potash to soil which is very poor in nitrogen or phosphoric acid would be comparatively useless. The heavy loamy or clay lands nearly always contain an abundance of potash and phosphoric acid in a more or less unavailable condition, and much of these materials can be liberated to the plant by careful tillage and the incorporation of humus. However, it is nearly always advisable, in orchards which are bearing, to add these materials in the shape of manures or concentrated fertilizers. The quickest results following the use of fertilizers will be seen alpon the sandier lands. Two or three years often elapse after the application of chemiral fertilizers to heavy lands before any decided results are observed. In other words, clay lands ordinarily show quicker resnlts from tillage than they do from the application of fertilizers. The farmer should hear in mind that he shonld never rely exclusively upon chemical plant-foods, because they contain no humus, and the soil is apt to become hard and lifeless. They should be used in judicious rotation, or in connection with cover crops, or stable manures, 
or applications of muck or some other organic dressings. It is not necessary that the chemical fertilizers should be mixed before application; in fact, upon lands of varying soil and conformation, it is ordinarily better to apply the different ingredients separately, because different parts of the plantation may need different amounts of the various materials. The low lands will ordinarily need less of the nitrogen and perhaps more of the potash and phosphoric acid. In general, it is advisable to buy the plantfoods separately, as advised in the preceding pages.

Farmers do not appreciate the importance of humus as an ameliorator of land. In farm lands, it is usually supplied in form of green erops, stubble or sward, and barn manures. When humus is absent, sandy soils become too loose and leachy and hot, and clay soils bake and become lumpy. The different physical characteristies of clay lumps and mellow soils are largely due to the greater amount of humus in the good soil, and yet we have seen that the ehemist may pronounce the eloddy soil richer in native plant-food. If the farmer has much of this hard, unproductive land, what is to be done with it? To eover it with commercial fertilizer would be of little benefit. It must first be put in fit condition for the growing of erops. A crop of clover plowed under would quickly improve it, but if the land is planted to orchard he does not eare to seed it down. The next recourse is stable manure. Of this, perhaps enough can be had to cover the hardest spots. For the rest, 
catch or cover crops must be used. Following the early tillage, he can sow rye, and plow it under very early in the spring. Now and then he can use a fall crop of sowed eorn or oats, or something of the kind. After a time, he may be able to get the land in such condition of tilth as to secure an occasional stand of erimson clover. This practice, continned judieionsly for a few rears, ought to radically change the character of the land; but all this will be of little avail unless the plowing and cultivation can also be done in a timely and intelligent way. All this will take time and patience. He may wish that there were some short-ent and lazy way of improving this land by making some applieation of fertilizer to it, but there is not. The most he can do is to slowly bring it into such condition that it will pay to put concentrated fertilizers on it. In short, the first step in the enrichment of unproductive land is to improve its physical condition by means of eareful and thorongh tillage, by the addition of humus, and perhaps by underdrainage. It must first be put in snch condition that plants can grow in it. After that, the addition of chemical fertilizers may pay by giving additional or redundant growth. All this means that no amount of penance in the way of applications to the land can ever atone for the sins of poor tillage; or, farming eannot be done by recipe.

The gist of the whole matter respeeting the use of fertilizers is that the grower should experiment with his plantation, adding a little more of this 
and a little more of that as he thinks the different trees or the different types of land may need. There is no other way of arriving at this local knowledge except by trying for oneself. If one is observant of the conditions, he will after a time come to have an intuitive sense of what the land probably needs, but he may not be able to tell just why it needs it. In most matters of handicraft in agriculture, the skilled man develops methods and results almost unconsciously. These methods are really founded upon close observation and truthful inductions, but the person can rarely ever impart this particular information to his neighbor. The only general statement, perhaps, which can be made, is that liberal applications of potash and phosphoric acid should nearly always be made to bearing fruit plants, if the grower desires the best results; and he may be able to supply his nitrogen more cheaply by cover erops and tillage than by buying chemicals. 


\section{CHAPTER V.}

THE PLANTING OF FREIT GROCNDS.

THE subjeets which one naturally eonsiders when starting ont to begin the planting of a fruit area fall into four categories, - the rhoice of the varieties, the selection of the trees or plants, the actual setting of the stock, and the laying out of the fruit plantation. These matters may now be considered.

THE CHOICE OF VARIETIES.

The most personal matter connected with the making of a fruit farm is the subjeet of choice of varieties. This is the one subjert upon which most questions are asked, and it is also the one upon which the least speeific and dogmatic advice can be given. The choice of rarieties depends primarily upon the personal preferenees of the grower, npon the purpose for which the fruit is to be grown, and upon the locality. Without knowing these three elements, it is impossible for any person to give satisfactory advice as to varieties. The grower who has no personal preferences for varieties is one who has not ret mastered the first essential to 
successful fruit-growing,-the obtainment of a specific ideal. In the greater number of cases it is easy to answer questions as to what varieties to plant by asking the questioner what he wants to plant. He will commonly answer his own question fully. The intelligent question about varieties is that which asks for specific information; as, for example : What is the best red fall apple for southern Ohio? What is the earliest raspberry? What is the hardiest apricot? What is the largest plum? What is the best strawberry for canning? Such questions as these indicate that the questioner has classified his own ideas, and that he is driving straight to the point for information; and they are usually capable of rather definite answer. When a man asks, "What variety of fruit shall I plant?" no one should attempt to answer. The writer has long since come to the practice of refusing to recommend specific varieties to individual persons. $\mathrm{He}$ prefers to name those varieties which he thinks might please himself for the purpose or place named, or to give lists of the kinds most likely to meet the requirements; but the grower must choose for himself.

There are a few general rules or precepts which may be stated to aid the intending fruit-planter in the choice of varieties:*

1. So far as possible, follow your own personal preferences, - the type of fruits which you love best

\footnotetext{
* The whole question of the running out of varieties is discussed in "The Survival of the Cnlike."
} 
or take most interest in. These are the ones with which you will most likely succeed.

2. Obtain a clear and specific ideal of the purpose for which the fruit is to be grown, - whether for dessert, for canning, for a local market, for export, for evaporating, and the like. Then ehoose the varieties which are best suited to meet these itleals.

3. Do not covet a variety simply beeause it is eminently successful in another region. Varieties have distinct adaptations to geographical areas. If a given variety is a universal suceess in the plains regions, the probabilities are that it will not thrive equally well in New England. The farmers of the east have learned that they eannot compete with those of the west in the growing of wheat, but they have not yet learned that one region may not be able to compete with another in some particular variety of fruit, even though the variety thrive well in both. It is a question if the northeastern states can compete with the mid-western states in the growing of the Ben Davis apple. The sonth and mid-south are being planted extensively to the Kieffer pear, largely beeanse it thrives better over a large area than most other varieties. It is doubtful, then, if it is wise to plant it extensively in the north, where other pears will thrive which do not suceed in the Kieffer region. Diversification must come to be more and more important in fruit-growing; and any region should grow that type of fruit most freely which other regions eannot grow so well. 
4. Choose with reference to the local environment. One must consider the adaptation of the variety to his particular climate, to the probable length of his season, to his distance from market, and to his system of husbandry. The adaptation of varieties to soils is an important consideration, and one which demands closer attention as cultivation becomes more intense and perfect. As a rule, the finer the variety in quality, the less able it is to thrive equally well under diverse methods of treatment. It is partly for this reason that dessert fruits are commonly regarded as unreliable and difficult to grow. One can scarcely hope for success in

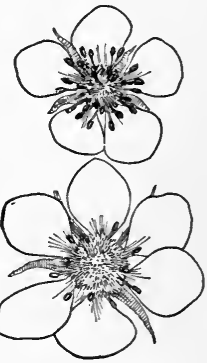

Fig. 22. Strawberry flowers modified by weather. the best horticulture unless he gives particular study to the adaptations of species and varieties to soils.

5. Choose with rererence to inter-pollination. It is known that some varieties of fruits are self-sterile,that is, they are not fruitful when planted alone. This sterility may be due, as in the case of the strawberry, to imperfect (or unisexual) flowers, or, more commonly, to pollen which is impotent upon the pistils of the same flower.* This infertility or selfsterility is largely a varietal characteristic, yet it is no doubt greatly modified by seasonal and environ-

* For a discussion of the philosophy of this self-sterility, see the essay on "Sex in Fruits," in "Survival of the Unlike," p. 347. 
mental conditions. It is probable that varieties may sometimes be self-fertile and at other times selfsterile. The strawberry flowers in Fig. 22 show the marked influence upon pollen-bearing which is exerted by different conditions. The flowers are of the same variety, and were grown under glass. The lower one shows the small development of stamens in a long cloudy spell, and the upper one shows the profusion of stamens which appeared in other flowers after two or three days of sunshine. It is probable that pollen is more profuse and more potent in some years than in others.

There is very little positive knowledge concerning the inter-pollination of fruits, and no subject eonnected with pomology is in greater need of study. We chiefly know that the most productive orchards are usually those of many varieties, and that some varieties sometimes refuse to fertilize themselves. The' most positive knowledge respecting the impotency of pollen amongst our common fruits is in connection with the plums of the Wild Goose type. The safest practice, therefore, is to plant no more than two or three rows of any one variety together of fruits in which self-sterility is a frequent characteristie (pears, plums, apples). The chief point to be observed in selecting the varieties is that they shall bloom together. All pears and apples, and nearly or quite all plums, seem to be inter-fertile when they bloom simnltaneously.

The following lists of self-sterile and self-fertile fruits are summaries of our present knowledge upon the subject: 
Pears-Varieties more or less self-stertile.-Angoulême, Anjou, Bartlett, Boussock, Clairgeau, Clapp, Columbia, De la Chène, Doyenne Sieulle, Easter, Gansel's Bergamotte, Gray Doyenne, Howell, Idaho, Jones, Kieffer, Lawrence, Louise Bonne, Mount Vernon, Pound, Sheldon, Souvenir do Congres, Superfin, Colonel Wilder, Winter Nelis.

Varieties generally self-fertile.-Bosc, Brockworth, Buffum, Diel, Doyenne d'Alençon, Flemish Beauty, Heathcote, Le Conte, Manning Elizabeth, Seckel, Tyson, White Doyenne.

Apples-Varieties more or less self-stertile.-Bellfleur, Chenango (Strawberry), Gravenstein, King, Northern Spy, Norton Melon, Primate, Rambo, Red Astrachan, Roxbury Russet, Spitzenburg, Talman Sweet, Willow Twig, Winesap.

Varieties mostly self-fertile.-Baldwin, Ben Davis, Codlin, Fallawater, Greening, Oldenburg, Rall's Janet, Red Astrachan, Smith Cider.

Plums - Varieties more or less self-sterile. - Coe Golden Drop, French Prune, Italian Prune, Marianna, Miner, Ogon, Peach, Satsuma, Wild Goose and many other native plums.

Varieties mostly self-fertile.-Burbank, Bradshaw, De Soto, Green Gage, Lombard, Robinson, Damsons.

Strawberries often lack stamens altogether, whilst others, like Crescent, have so few and so poor stamens that they are practically self-sterile. Ordinarily, there should be a row of a perfect-flowered variety for every two rows of a pistillate or infertile variety. 
"The quince seems to fruit nearly as well with its own pollen as with that of another variety." -Waite.

Grapes (Beach)*_Unfruitful uhen planted by themselves.-Black Eagle, Brighton, Eumelan, Massasoit, Wilder, Rogers' No. 5, Gaertner, Merrimac, Requa, Aminia, Essex, Barry, Herbert, Salem.

Able to set fruit of themselves. - Concord, Diamond, Niagara, Winchell or Green Mountain, Rogers Nos. 13, 24, and 32, Agawam, Delaware.

Some of the self-sterile varieties mentioned have fruited well when planted with pollenizers as follows: Bartlett with Nelis, Flemish, Easter; Kieffer with Le Conte, Garber; Coe Golden Drop with French Prune, Fellenburg; Satsuma with Abundance, Burbank, Red June; Miner with De Soto, Forest Rose, Wild Goose; Wild Goose with De Soto, Newman, Miner.

6. Determine which are the best varieties for your purpose by experimenting, and by diligent inquiry of neighbors, pomologists, nurserymen, books, experiment stations, $\dagger$ and of marketmen.

\section{THE SELECTION OF THE PLANTS. $\ddagger$}

It is first of all necessary, in selecting the plants for fruit grounds, to determine what first-class stock is. "The nurserymen contends that he grows the

*For recent notes, see Beach, Bull. 169, N. Y. Exp. Sta.

†Notes upon the uses of variety tests by experiment stations will be found in "Survival of the Unlike," pp. 171 and 370 ,

tThe Methods of propagating are fully set forth in "The Nursery-Book." 
varieties which the planters want - those for which there is a demand. As a matter of fact, he largely forces the demand by magnifying the value of those varieties which are good growers in the nursery. The nurseryman's business ends with the growing of the young tree, and the tree which makes the straightest, most rapid and cleanest growth is the one which finds the readiest sale. Now, it by no means follows that the variety which is the cheapest and best for the nurseryman to grow is the best for the fruit-grower. Probably every apple-grower is now ready to admit that the Baldwin has been too much planted, whilst Canada Red and various other varieties which are poor growers in the nursery row have been too little planted.

"The blame for this condition of things does not rest wholly with the nurseryman, although it is partly his fault. The original difficulty lies in the fact, it seems to me, that our conception, and consequently our definition, of what constitutes a firstclass tree is at variance with the truth. We conceive a first-class nursery tree to be one which grows straight and smooth, tall and stocky, whilst we know that very many - perhaps half-the varieties of apples and pears and plums will not grow that way. In order to make our conception true, we grow those varieties which will satisfy the definition, and, as a result, there is a constant tendency to eliminate from our lists some of the best and most profitable varieties.

"All this could be remedied if people were to be 
taught that varieties of fruit trees may be just as different and distinct in habit of growth as they are in kind of fruit, and that a first-class tree is a wellgrown specimen wich has the characteristics of the variety. It seems to me that it is time for nurserymen to begin to enforce this conception upon the public. Why may not a catalogue explain that a tree may be first-class and yet be crooked and gnarly? Why not place the emphasis upon health and vigor, and not upon mere shape and comeliness? And why may not a nurseryman give a list of those varieties which are comely growers, and another list of those which are wayward growers?"*

It is generally best to buy first-class trees,those which are of medium size for their age, shapely in body and head, stocky, with straight, clean trunks and abundant roots, which are not stunted, and are free of borers and other injuries, and, in the case of budded trees, those in which the union is very near the ground; and the tree should show the natural characteristies of the variety. In dwarf pears, especially, it is important that the stock, to be first-class, shall be budded very low. It is often thought that large size is of itself a great merit in a nursery tree, but this is an error. Vigor, cleanness, stockiness, firm, hard growth, are much more important than bigness. The toughest and best trees are usually those of medium size. The very small extra expense which

*"The Survival of the Unlike," p. 246. 
one incurs in buying the best trees is a good investment. In an acre of apple trees, the difference in cost of first-class over second-class trees will not be more than a dollar or two, but the difference in results is often great.

The age at which plants should be bought must be governed by circumstances and by variety. There is a general tendency to buy trees too old rather than too young. When varieties are new and scarce, it may be economy to buy young stock. Some of the freer-growing apples and pears are large enough when two years old, if grown from buds; but these fruits are usually set at three years from the bud or graft. Dwarf pears may be set at two or three years, preferably at the former age. Quinces are set at two and three years. Peaches are set at one year from the bud. Strawberries are set only from new plants (that is, those which have not borne); gooseberries and currants preferably from two-year stock, and raspberries and blackberries from stock not more than one season old.

Dwarfs vs. standards.-Fruit-growers are always asking whether standard or dwarf "trees are the better to plant, but the question is a personal one, and cannot be answered for another any more than the question can as to whether peaches are more desirable than plums. Dwarf apples and dwarf pears are of a different type of fruit-growing from the standards, and the intending grower must weigh the evidence for and against as best he can. As a general thing, the standards are the 
safer and more reliable; but persons who are willing and competent to give the extra care which the dwarfs need, and who have access to extra good markets, may generally grow the dwarfs with profit.*

The parentage of the cion may affect its value."It is probable that many trees fail to bear because propagated from unproductive trees. We know that no two trees in any orchard are alike, either in the amount of fruit which they bear or in their vigor and habit of growth. Some are uniformly productive, and some are uniformly unproductive. We know, too, that cions or buds tend to reproduce the characters of the tree from which they are taken. A gardener would never think of taking cuttings from a rose bush, or chrysanthemum, or a carnation, which does not bear flowers. Why should a fruitgrower take cions from a tree which he knows to be unprofitable?

"The indiscriminate cutting of cions is too clumsy and inexact a practice for these days, when we are trying to introduce scientific methods into our farming. I am convinced that some trees cannot be made to bear by any amount of treatment. They are not the bearing kind. It is not every mare which will breed or every hen which will lay a hatfull of eggs. In my own practice, I am buying the best mursery-grown stock of apples (mostly

* Further remarks upon dwarf trees may be found in Nursery•Book, 3d ed., and in Lodeman's "Dwart Apples," Bull. 116, Cornell Exp. Sta. 
Spy), and am top-grafting them with cions from trees which please me and which I know to have been productive during many years. Time will discover if the effort is worth the while, but unless all analogies fail, the ontcome must be to my profit." *

If one is to plant hardy stocks and then work them over, he should usually plan to graft or bud them after they have stood in the orehard one year. Good results sometimes follow grafting in the very year in which, the stock is set, but this is the exception. Some persons have proposed to sow seeds in the very spot where the trees are to stand, and thereby to raise stocks for top-working without transplanting them, but the labor and uncertainty of the method make it impracticable. It is cheaper to grow trees in the nursery row-the same as it is cheaper to buy trees of a nurseryman than to attempt to grow them-and the trees also receive better care. Again, seedlings vary, and the poor and weak ones should be discarded the same as they are by the budder in the nursery row who finds them to be too small or too scrawny to bud. Well-grown stock of a stronggrowing variety usually gives more uniform results than a lot of home-grown seedlings can.

Buying the trees.- It is best, when it can be done, to order trees late in summer or early in the fall, if

* L. H. Bailey, Bull. 102, Cornell Exp. Sta. See, also, "Survival of the Enlike," pp. 249, 250. 
one expects to plant an orchard. Buy where the best trees can be obtained, and where there is good reason to expeet reliable stock and honest dealing. It is generally advisable to buy at the nearest nursery at which the desired stock ean be seeured, for the buyer has more personal knowledge of the nurseryman, he can visit the nursery, he saves freight, and he may be able to secure his stock in fresher condition; but trees of equal excellence will generally thrive equally well when transported from long distanees, if they arrive at their destination in good condition. While one should endeavor to secure low prices, it should be remembered that nursery stoek should never be purchased simply because it is eheap. Poor stoek is dear as a gift. Yet farmers who annually plant a few trees, and who buy of agents, often pay exorbitant prices. In a certain town, when farmers were paying 28 eents apiece for peaeh trees in lots of a dozen, any reliable nursery would have been glad to have supplied the same rarieties at $\$ 8$ per hundred, at the nursery. Plums which should have sold for 15 eents to 20 cents apieee were selling to farmers for 50 and 60 cents apieee. The man who serionsly expeets to plant an orehard for profit will not be led into any wild seheme or new varieties by agents. He will generally buy directly of the nearest nurseryman who ean supply the desired stoek and varieties at the priees whieh suit him. Some nurserymen employ regular and reliable agents, and such agents earry a certifieate from the firm they represent. But while these salesmen may be perfeetly straightforward, and may 
be the best channels through whom small orders can be secured by those who are uninformed in pomological matters, all persons who expect to go into fruit-growing seriously should buy directly of the nurseries. But it must always be remembered that the tree agent has been the means of clothing the country with fruit trees, and of thereby adding much to the contentment of farm life.

The buyer should make up his mind just what varieties he wants, and then find the nursery which has them, and order early enough to get them. There is then no occasion to consider the vexed question of substitution of varieties. If the varieties are not in market, buy stocks of some strong-growing, staple variety, and after these are established-usually the spring or summer of the next year-bud or graft over the tops to the desired varieties.

\section{THE SETTING OF THE PLANTS.}

When to plant. - There is much difference of opinion as to the relative merits of fall and spring planting. The writer's opinion is that fall planting is generally preferable to spring planting upon thoroughly drained soils, particularly for the hardy tree fruits, like apples, pears and plums; and if the ground is in good condition and the stock well matured, peaches can sometimes be set in October, even in the northern states, with success. The advantages of fall planting are several. The trees become established during the open weather of fall, and they usu- 
ally make a start in spring before the ground is hard enough to allow of spring planting. This early start not only means a better growth the first season, but, what is more important, trees which get a very early hold upon the soil endure the droughts of midsummer much better than trees planted in spring. Planting is nearly always better done in the settled weather and workable soil of fall than in the eapricions days and in the hurry of springtime; and the orehardist is free to begin eultivation at a time when he would otherwise be planting his trees. Again, it is generally better to buy trees in the fall, when the stoek of varieties is full and when the best trees are ret unsold: these trees must be kept until planting time, and it is about as eheap and fully as safe to plant them direetly in the field as to heel them in until spring.

In fall planting, however, it is important to insist that the trees shall be thoroughly well matured. In order to move stock quickly, it is the praetice of some nurserymen to "strip" the trees before the growth is completed; that is, the leaves are stripped off, the growth stopped, and the trees are put upon the market for September deliveries. This process weakeus the trees, and many failures in young plantations are probably attributable to this eause. Such trees may die outright, especially if set in the fall and a hard winter follows; or they may live to make a dwindling growth for the first few years. Like early-weaned calves, they lack vitality and push. If one were setting an orehard in the fall, he should 
place his order for trees in August or September, if possible, with the express stipulation that the trees should stand in the nursery rows until the leaves begin to die and fall. In the meantime, the land should be fitted and the holes dug, so that when the trees arrive they ean go directly into their places without delay or without the expense of heeling them in. Trees are mature enough to dig late in September or early in October in the northern states, depending upon the season, soil and rariety. When the tree is fully mature, some of the leaves will still hold upon the vigorous shoots, and these are stripped off; but this stripping does no harm, for the young growth is then mature and it has a thick, strong, brown appearanee which is very different from the slender, soft and green branches of early-stripped trees.

It should be said that there seems to be a tendency amongst nurserymen to urge fall planting in order to push sales; and there are many good planters who consider fall planting hazardous, especially in the north. It is true that unless the conditions are right, spring planting is the safer course; and farmers who have many fall crops to harvest will also probably find more time for tree setting in the spring.

Distance apart.-Fruit plants are oftener set too close together than too far apart; in fact, the latter error scarcely exists. Trees, especially, are wide feeders; and the best results are obtained when each tree stands far enough from its neighbors to 
allow it to possess an individuality all its own. An additional reason for sparse planting has lately become important, - the necessity of spraying for insect and fungous pests; and for this reason, as well as to allow of better cultivation, the ontside rows should not he sot close to fences. The distance at which trees may be set depends much upon the system of pruning. If heading-in is followed vigoronsly and systematieally, trees may be set a third nearer than if allowed to take their natural form. Heading-in should always be practiced with dwarf pears, and many of our best growers pursue it with peaches, plums and quinces. Thin planting is the safer rule for the majority of eases. The following table may be supposed to represent the ontside average limit for the planting of fruits in New York, when the plants are allowed to take their natural form:

Apples,

- dwarf,

Pears, standard,

- dwarf,

Quinces,

Pearlies and Nectarines, $20 \mathrm{ft}$.

Plums,

Apricots,

Cherries, somr,

- sweet,

Figs,

Kaki,

Pecans,
$40 \mathrm{ft}$. each way.

10 to $15 \mathrm{ft}$.

20 to $25 \mathrm{ft}$.

$12 \mathrm{ft}$. to 1 rod.

1 rod.

$20 \mathrm{ft}$.

$20 \mathrm{ft}$.

$20 \mathrm{ft}$.

$30 \mathrm{ft}$.

20 to $25 \mathrm{ft}$.

20 to $25 \mathrm{ft}$.

$40 \mathrm{ft}$. 

Oranges and Lemons, 25 to $30 \mathrm{ft}$.
Grapes,
Currants,
Blackberries,
Raspberries,
Strawberries,
Cranberries,
$6 \times 8$ to $8 \times 10 \mathrm{ft}$.
$4 \times 6$ to $6 \times 8 \mathrm{ft}$.
$4 \times 7$ to $6 \times 9 \mathrm{ft}$.
$3 \times 6$ to $5 \times 8 \mathrm{ft}$.
$1 \times 3$ or $4 \mathrm{ft}$. [way.
1 or 2 ft. apart each

These are safe distances. In certain cases, however, where the soil is strong and the grower makes thorough work of cultivating, pruning and fertilizing, these distances ean be reduced somewhat with profit, except, perhaps, in the case of apples. (See, also, remarks by Van Deman, page 273.)

The quineunx system plants in triangles rather than in squares. The triangles may be equilateral, in which case all distances are equal. Usually, however, a fifth tree is set in the center of a square; this system therefore requires twice the number of trees needed for ordinary planting, not counting the uneven ends.

The mixing of species, or double planting.-These remarks upon the proper distances for trees call for some discussion of the common question as to whether it is good policy to plant shorter-lived trees, as peaches, between apples and pears. It all depends upon the man. In general, it should be discouraged; but if the orchardist gives the very best attention to fertilizing and cultivating, plantations can be mixed with good results. This mixing of species is a personal question. Now and then a man succeeds admirably with it, but the greater number fail to 
secure very good results with more than one type of effort upon the same piece of land.

Van Deman* writes the following upon this subject: "For a number of years, the trees will necessarily have much more space than they really need, if planted the distance apart that they will require when grown to full bearing age. Not only will there be wide spaces between their tops, but much of the soil will be unocenpied by their roots. Therefore, some plan for using this space without in any way hindering the proper growth of the trees, is permissihle, economical and desirable. Many plant peach trees among their apple trees to fill the spaees until the apple trees get old enough to need all the room. I have done so myself, but do not like it now. The peach trees are of quicker growth, and rob the apple trees to a damaging degree, in many eases. Dwart pears are oceasionally set in apple or standard pear orehards, but this is generally a mistake, because the trees often need very different enlture, espeeially when the pear trees blight badly from too rapid growth. Moreover, if the dwarf pear trees are planted deep, they send out pear roots above the quince stocks, and become almost as long-lived as the other trees. The wiser plan is, usually, to plant apples, peaches, pears, cherries, plums, apricots, ete., by themselves, but to fill up the spaees until the permanent trees need the whole, plant varieties of

*H. E. Van Deman, "Plans for Orchard Planting," Rural New-Yorker, March $6,1 \times 97$. 
the same species that will come into bearing early. "Not only do different kinds of orchards fruits require different distances between their trees, but the same species or the same variety often needs more or less space in different climates and soils. Despite all the manuring or cultivation we may give them, those planted in some localities will not attain the same size as they would had they been planted in others. For instance: the peach trees of Connecticut and northern Michigan are much smaller than those of Delaware and Missouri. No manner of treatment will cause them to grow to the same size, unless those in the more southern locality were cut back in summer time or starved, and thereby stunted. It is climate that does it-more warmth, more sunlight, and, in short, more congeniality. The apple trees of Michigan and New England are far larger than those of Texas and the tide-water sections of Virginia, because the apple delights in a climate both moist and cool. The gigantic cherry trees of the Shenandoah Valley far exceed in size those which grow in the richer lands of Illinois.

"Where land is dear, economy of space is an important point; hence the plan that will put the most trees on a given area, provided they are not too thick, is the best. The more there are on an acre, the less it costs per tree to cultivate them."

Some of the small-fruits may be planted in orchards with the very best results. Strawberries are practically an annual plant, and are much better for orchards than any kind of a sowed crop is. 
How to plent the stork.-Plow the land and fit it well. As all fruit grounds should be put into eultivated cops for the first two rears, at least, it will generally be found alvisable to plow the entire area before the place is set, rather than to plow strips where the trees or plants are to go, for the land "an then be shaped better with referenee to surface drainage and general eonvenienee.

Trees should be set neither in dead-furrows nor on back-furrows. Level eulture should generally be adopted from the start, unless it is known to be neeessary to displace surface water; and in that case it may be questioned if the land is fit for fruit plants. In all ordinary soils, holes must be dug by hand for the tree fruits. Plowing out a deep furrow in the line of the rows may lessen the digging and aid in getting the trees in line. The hole should be dug broad and ample; and the harder the soil the larger ought the hole to be, for in that case the loose dirt whieh is filled in must give the tree its start. In loose and deep soils, the hole need he no larger than the spread of the roots. Chop up the soil in the bottom of the hole, or throw in a few shovelfuls of loose surface earth.

Trees should be set an inch or two deeper than they stood in the nursery, for the loose earth will settle and wash away in the eourse of the season, even if it is well packed when the trees are set. Dwarf pears should be sot from three to six inehes below the bud. The roots are trimmed, as explained further on. Every eare must be exereised 
to get the soil thoroughly firmed in about the roots-which are straightened out in approximately their natural position-and especially under the erown or fork of the roots, in order that no air-spaces may be left to dry out. This dirt can be best placed by fingering it in, moving the tree gently up and down at the same time. Once or twice in the progress of filling the hole, the earth should be stamped down. Fill the hole to a little more than level full to carry off surface water, but be careful that no hollows are left too close about the tree into which water can settle, especially when planting in the fall. Stamp or pound the earth very firmly about the tree before leaving it, for the double purpose of retaining moisture and of holding the tree against winds. Small stuff, like nursery stock and small-fruit plants, may often be well planted by means of a dibber or spud. All this operation of planting can proceed to perfection only when the earth is dry enough to crumble. Stock cannot be well planted in wet and sticky soil.

If trees are set according to these directions, and the tops are cut back as explained farther on, there will rarely be any necessity for staking and tying the trees to keep them plumb.

Mulches of straw or manure are sometimes advised for newly set trees. For trees planted late in spring and upon droughty soils, a light mulch about the tree may be advised; but in other cases it is not. If mulches are applied to fall-planted trees, eare must be taken to tramp them down well, or 
they may become a nesting-place for mice, which may girdle the trees when there are heavy snows. There are those who favor plating a forkful of manure in the hottom of the hole, but this is a prartice of doubtful value; and, at all events, the manue should be well mixed with the soil to prevent drying out. There is often discussion as to whether it is desirable to place the mulch on the surface or to place it an inch or two below the surface and cover it with soil. No dogmatic assertion can be made for either method, although, of the two, the former is probably more generally advisable. But it should be remembered that a muleh of tilled earth (as explained in Chapter III.) is more desirable than one of straw or manure in general fruit-planting.

Puddling the roots is a good practice when trees are to be shipped any distance or when they are likely to be unduly exposed, and it is a common practice amongst nurserymen. The operation consists in sousing the roots in a thin mud or paste of clay.

Trimming the trees. *-There is much difference of opinion as to the best method of trimming trees when they are set. So far as the root is concerned, it is advisable, in the north, to eut away only those roots which are broken or badly torn. These should be ent off just back of the injury. It is the custom

\footnotetext{
*Complete discussions of pruning and training, with a full analysis of the Stringfellow or stub-root method, may be found in "The Pruning-Book."
} 
to eut off the ends of all roots of the size of a lead pencil or larger, for a clean, smooth wound is supposed to heal quicker than a ragged one. These cuts are made from within outwards, so that the wound is more or less slanting across the roots, and so that it rests firmly upon the ground when the tree is set. When the tree is planted, all the roots should be straightened out to nearly or quite their normal position. If it is found that one or two roots run off to an inordinate length, they may be cut back to correspond somewhat with the main root system.

Perhaps half the entire root system of the young tree is left in the ground when it is dug. It is therefore evident that the top should be cut back to a corresponding amount. In fact, the top should be more severely shortened-in than the root, because the root, in addition to being reduced, is also dislodged from the soil, with which it must establish a new union before it can resume the normal activities. Trees which are allowed to carry too much top when planted may fail to grow outright; or if they start, they are very likely to be overtaken by the droughts of summer. Even if they live, the growth is generally small and uncertain, and the tree may fall a prey to borers or a vietim to high winds. On the other hand, trees may be trimmed too severely when set. Except possibly in the case of peaches, it is probably unwise to trim the trees to a mere pole; and with peaches, it may be better to leave spurs with at least one bud than to trim to a whip. There should be a number of strong, bright buds left upon 
the top, for these are the points where early and active growth begins. These buds are upon strong branches. If they are removed, the weaker or half

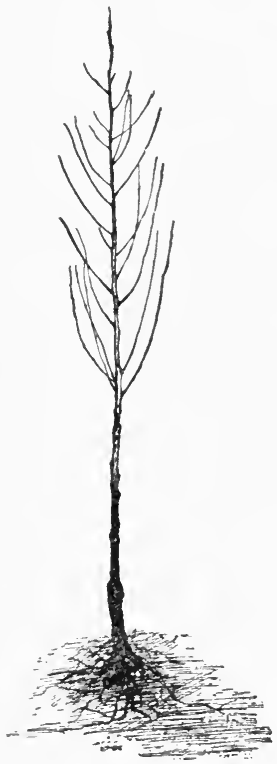

Fig. 23. Yearling peach tree.

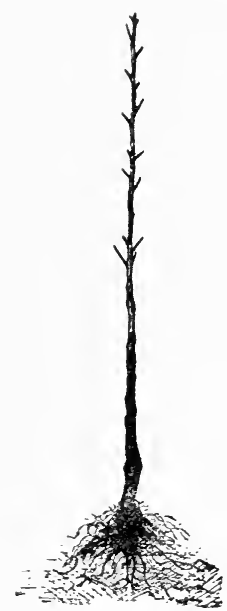

Fig. 24. Peach tree, pruned.

dormant buds upon the main trunk or low down in the crotches, must take up the work, and these start slowly and often feebly. 
There are two general methods of trimming the tops of young trees at planting time. One method cuts back all the branches to spurs of from one to three buds; or sometimes, particularly with dwarf pears set when two years old, the side branches may be cut entirely away, leaving only the buds on the main stem or trunk. The tree, therefore, "feathers out" the first season; that is, it makes many small shoots along the main trunk. The following fall or spring, the top is started at the desired height. Fig. 23 shows a peach tree as received from the nursery, and Fig. 24 the same tree, trimmed in this manner, ready for planting. This method is the one generally best adapted to the peach, which is always set when a year old; but for other fruits, unless the trees are slender and without good, branchy tops, it is doubtful if it is the best practice. If the bodies are thought not to be stiff enough, this manner of trimming may be used to good advantage. The main shoot should usually be headed back in this as in all styles of trimming, in order to make the trunk stocky.

The second method aims to start the top at the required height when the tree is planted. It is adapted only to strong and well grown stocks which have a more or less branching and forking top. From three to five of the best branches are left, and these are headed back to a few buds each Fig. 25 shows a pear tree, trimmed in Fig. 26, and the illustration may be considered to represent a good example of its class. Many of our best plant- 
ers prefer the spur system for all trees, and there are some who would trim all newly set trees to a

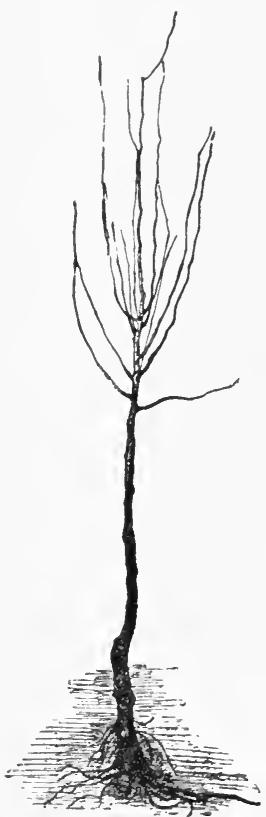

Fig. 25. Three year old pear tree.

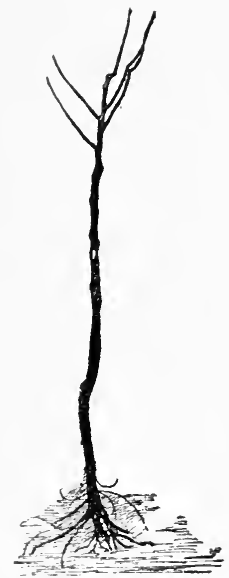

Fig. 26. Pear tree pruned.

straight whip. There is much to be said for this latter method. 


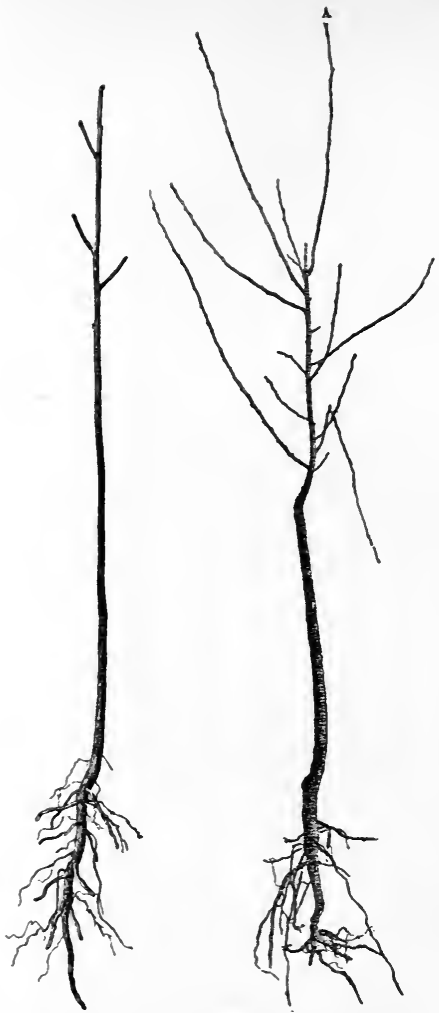

Fig. 27. Young plum stock well trimmed.
Fig. 28. Second-class apple tree, showing leader at $A$.

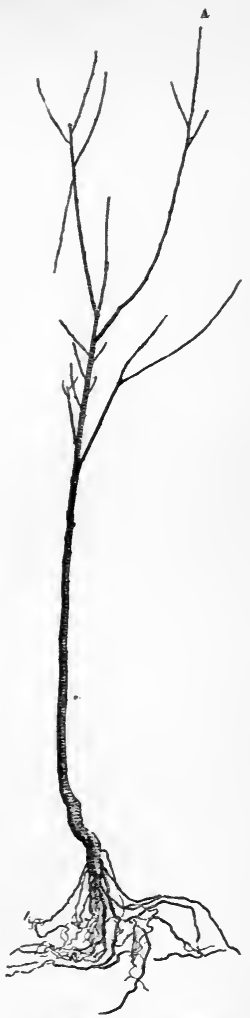

Fig. 29. Second-class tree, showing leader at $\mathbf{A}$. 


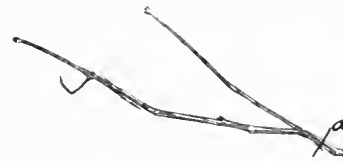

It is, of course, evident that there is no one method of pruning young trees which is all wrong, nor any other which is all right. The method must always be modified by the age and shape of the trees, by the climate (or part of the country) in which the plantation is set, by the species of plants, and especially by the ideal which the grower has set for himself. In general, it may be said that the younger the stock the more nearly to a whip it may be pruned.

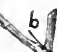

3 


\section{Trimming the Young Stock.}

It may be said in general, then, that peach trees and small or slender trees should be well headed back and spurred (Figs. $23,24)$; but that strong, well branched trees may have the head started at the desired height at the time of setting, all the branches being well headed back (Figs. 25 and 26). Fig. 27 shows a small plum tree cut to spurs, and the roots have also been properly dressed. Figs. 28 and 29 show secondclass apple trees. In these the tops are not well formed, and it might be best to trim to a whip, allowing the branches $A$ to become the leaders. Such whips may look very crooked and scrawny, but they will straighten as they grow. The lines in Fig. 30 show where

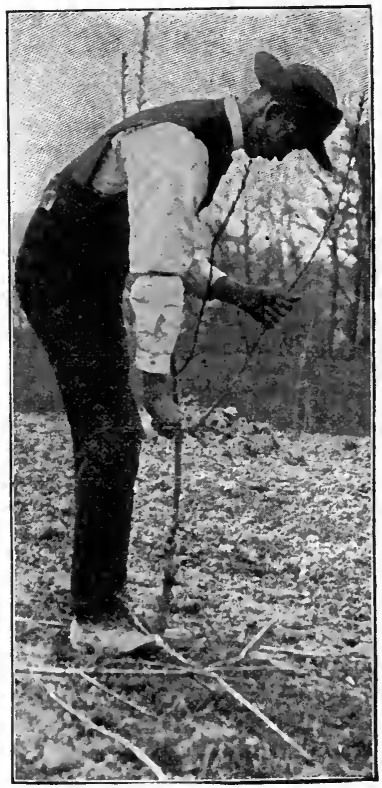

Fig 31. Pruning a newly-set tree.

a grape plant should be pruned. The top should be cut at $a$ and $b$, the upper roots trimmed off at $c$ and $d$, and the main roots cut in from $e$ to $f$. 
The trees may be trimmed before they are planted, although it is generally better to do it just after they are set, especially if the tree is trimmed after the mothod of Fig. 26, for one can then better estimate the proper height, the operation is easier done, and there is no further danger of breaking off the limbs by the handling of the tree. One foot is planted firmly at the base of the tree, and then with one hand the branch to be removed is bent upwards and with the other the knife is applied to the under side and the cut is made neatly and easily (Fig. 31, page 253). Never cut downwards on a limb, for a ragged wound nearly always follows.

In fall-set trees it is generally inadvisable to prune them before spring (unless the tops are so heary and the bodies so weak that they are likely to be injured by wind), because the cnt surfaces are likely to dry out. The roots of the tree are not ret sufficiently established in the soil to supply the added eraporation which takes place from the wounds. If it seems to be desirable to trim the trees when they are set, they should be eut back only part way. They may be eut again, to fresh wood, in the spring.

\section{THE LAYING-OUT OF THE FRUIT PLANTATION.}

It is diffieult to make the rows straight in large areas, especially on rolling ground. Persons who have had areas regularly surveyed with ehain and compass, and a stake set for every tree, may have 
found the orchards to be as crooked as others set with much less care. The surveyor sets his stakes by sighting across the field from certain fixed points; but it is difficult for the planter, when the stake is removed and the hole dug, to stand the tree in the exact place of the stake. It is better to regard the trees as stakes and to set them by sighting. The area can be "run out" on two or three of the sides, a conspicuous stake being set at the location of each tree on these outside rows. If the field is large or rolling, it may be necessary to set one or two lines of stakes across the center of the field also. For areas of a few acres, a gardenline stretched across the field will be found to be a great help and to save much time. This line is moved at either end to the adjoining row, as soon as one row is set alongside it. Persons sometimes tie conspicuous strings on the line at the given intervals between the trees, expecting to set a tree at every knot, but with the stretching of the line, and other sources of error, it is nearly impossible to get the cross rows straight in this manner, and the trees must be kept in line by sighting.

Upon comparatively level fields, especially if the land is in good tilth, the plantation may be laid out with a corn-marker. If the planter keeps his back to the row of trees and sights ahead to the marked line or furrow, he will get his rows straighter than he will if he sights by the trees. Two men are better than one when setting plants, for one usually attends to the sighting whilst the other 
puts in the plants. There are various devices for lorating the position of the original stake, after the hole has been dug. One of the best consists simply of a thin board three or fon inches wide and six or seven feet long, with a notch at its center, and a stationary leg or pin at one end (a). The other end (b) is provided with a hole to receive the top of another stake or pin. The notch is set against the stake, the legs at each end of the board being thrust into the ground at the same time. The end (b) is now raised off the pin or leg, and the board is swung around out of the range of the hole. When the hole is dug, the end (b) is swung back and dropped upon the pin, and the tree is set in the notch.*

The methods of laying out orchards have been discussed in detail recently by $\mathrm{H}$. E. Van Deman, formerly pomologist of the United States Department of Agriculture, and eopious quotations are made from these writings. $\dagger$

"To lay out with the plou.-Before doing anything, one must decide which style or arrangement of the trees is to be followed and the distance apart to plant them. This having been decided, the first thing to be done is to establish a base line, which should be along a fence, road or some other permanent border of the tract to be planted. Prepare

\footnotetext{
*The reader will find this implement and another one illustrated on page 56 of "(iarden-Making."

†H. E. Van Deman, "Laying Out Orchards," Green's Fruit Grower, April, $189 \%$.
} 
enough small split stakes, that may be easily seen, to put at each end of every tree row; that is, enough to go entirely around the tract. Then, set a stake firmly at a spot which shall be the first established corner of the outside limits of the orchard. It must, however, be set at a spot which shall also be the end of another line running exactly at right angles to the base line. In the west, where the farms are nearly all laid out in perfect squares or rectangles, the fields are apt to be rectangular. In the absence of a surveyor's transit, a carpenter's square may be used to establish the lines, by sighting along its edges when laid on the tops of three stakes at the corner. Set a stake at the farther end of each of these lines. From this first corner stake measure along the base line fifteen feet, or as far as it is thought best to have the width of the margin between the trees and the fence, and there set a stake. Next, measure along the base line from this second stake the distance that the trees will be apart, and set a stake. Measure along the entire length of the base line, setting a stake at every $16 \frac{1}{2}, 20,25,33$ feet, or whatever distance may have been decided upon. This line of stakes being only the ends of the transverse rows and not the places for trees, they need not be set absolutely in a straight line, but should be nearly so. Then, go back to the original corner stake and measure fifteen feet at right angles to the base line and set a stake, which determines the width of the border next the base line. Now, 
mesture and set stakes along this other side of the wrhard site, up to the stake at the farther end. The two remaining sides should be measured and staked in the same way.

"Provide several tall stakes with a white rag tied at the top of each, to use as sight poles at each end. If one ean run a straight line with a plow without intermediate sight poles, that is, with only one at each end, these will be enough; but I have found that it pars to have an extra line of stakes set a few rods from each end, and a guide pole to be set at each in turn, as the laying-out progresses.

"We are now ready for the plow. Some like one horse, hut two make the plow run steadier, and it is easier for the plowman to sight between two horses than over the head of one. My plan is, to first mark out crosswise to the way I intend to plant, and to make but a single shallow furrow. This being done, we are ready to make the furrows in which to plant. If these rum up and down the slope they will act as a drain to the trees, in some measure. By plowing two rounds and finishing with a dead-furrow or trench on the line, and then subsoiling in the bottom of it, there will be very little work for the spade in preparing to set the trees. It is by no means diffieult to set them in the checks, with a little sighting, so straight that no one would know but that they were set hy a line. After setting the trees, hitch on horse to a plow with a very short singletree covered 
with rags at the ends to prevent injuring the trees, and fill up the trench at two rounds. Then plow the space between the rows. One thing must be very carefully figured out the very first thing, if the hexagonal style is used (which I prefer and use), and that is, the distances between the rows at right angles, and not diagonally from tree to tree, and then accurately measured and staked on the outer lines. The great Wellhouse orchards, in Kansas, were laid out with the plow. J. H. Hale substituted a 60-cent per day darkey and a mule for a six-dollar surveyor and transit, in laying out his rows for planting his 600-acre peach orehard in Georgia.

"Laying out with a line.-For small orchards of an acre or two, I have often practiced a method of laying out in the hexagonal style, which is very quickly and easily done. As many stakes are provided as there are trees to be set. A wire is prepared of the exact length that the trees are to be apart, and a ring or loop twisted in at each end, by which to hold it. A base line is established by setting stakes just where each tree will be in the first row. One person (A) slips a finger through one ring, and another (B) takes the other end of the wire and runs a small stick through the ring. A holds his end exactly at stake 1, and B steps to where he supposes the first tree of the second row will come, and with the point of his stick marks a small segment of a circle on the ground. He remains there while A goes to stake 2 and holds his end exactly to it. B describes another are on the 
ground, and where it crosses the first one he sets a stake, and moves to the plaee for the next stake. There he makes a mark, and $\lambda$ then goes to stake 3 of the base line and holds the wire as before, while $B$ finds the crossing of the marks and sets another stake; and so on to the end of the row. When the second row is eomplete it is used as a hase line from which to make a third, etc., ete. If the work is done carefully the stakes will be found to be in very straight rows every way. I have tried it on some of the ronghest hills in northern Michigan, where, in newly eleared places the stumps were very thick, and planted nice orchards that are now over twenty-five years old, that look to-day as if the trees might have been set by a eompass and ehain. On level gromd, free from obstruetions, it is fun to lay ont an orchard so.

"Another line method.-Another cheap and handy method is, to mark and set by a wire long enongh to reach entirely aeross the field. It shonld be stretched tightly between two stont stakes that have been firmly driven into the ground, and exactly on the line of the first row to be planted. Direetly over the place for the first tree or vine, wrap a small wire two or three times and twist the ends tightly, so it cannot slip. Measure along the wire to the next place and fasten another wire eoil, and so on to the end. If these little eoils were soldered fast they could not move. A little piece of bright cloth shonld be tied over them, that the places may be easily seen. Now, dig the holes and plant the 
first row while the wire is in place. Then move the wire and stakes to the second row and stretch as before, being very careful to have the first mark exactly where the first tree should be. Proceed to dig and plant as before. Move the wire to the third row, and so on throughout. This obviates all necessity for marking off upon the ground, except the distances between the rows and a starting point on each row. Some of the most accurately planted orchards and vineyards I have ever seen were planted by this method at the North Carolina Experiment Station at Southern Pines, and elsewhere in that region, and there I got the idea. It is entirely practical. The wire can be wound on a reel, and thus be easily moved about the farm or stored for further use."

Staking methods.-There are so many methods of staking out an orchard, that it will interest the reader if one of the best of them is described. The Yeomans plan is as follows:* "In connection with the accompanying diagram, is explained an casy, simple and accurate way of marking out the ground and planting the trees without putting any stakes where trees are to be planted or removing any while planting. The stakes not only show where to dig the holes, but when the planting is to be done the same stakes indicate the precise place where the trees are to be placed, always sighting only by the stakes in setting, without any regard

*T. G. Yeomans, Walworth, N. Y., Country Gentleman, Ixi. 288 (Apr. 9, 1896). 
to the trees planted. Thus all the stakes will be standing when the last tree is planted, showing the accuracy of the work done.

"The outside line of the diagram represents the

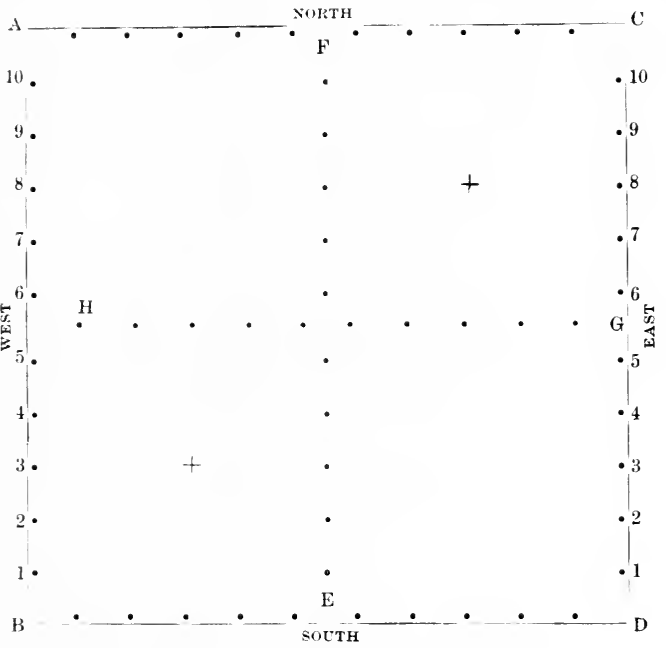

Fig. 32. Diagram to illustrate the planting of an orchard.

ground to be planted; the dots are stakes, by means of which the location of each tree can readily be found withont any measurements; but none of them stand where trees are to be planted. The ground being properly prepared for one hundred trees, pro- 
vide sixty lath as very suitable stakes-light, straight and of proper length-lay them on the ground or a board and whitewash on each side about a foot or more at one end, by which they can readily be seen at a distance and distinguished from any other stake or object. Let two men with a tape line start at the corner of the ground at $\mathrm{D}$, and measure 25 feet along the east side to 1 and then set a stake; thence measure 40 feet to 2 , setting a stake, and continue to 10 , putting a stake every 40 feet to $\mathrm{C}$, setting all stakes as perpendicular as possible.

"Then with ten stakes start at $B$ and measure the same distance toward $A$, sticking a stake first at 25 feet, and after that 40 feet, to correspond with those on the east side. And on the same plan and in the same manner, stick ten stakes 40 feet apart along the north and south bounds of the orchard, and entirely outside of where any trees are to be planted, being particular that no trees shall be planted nearer than 25 feet to the fences surrounding the orchard, for the reason that when the trees become large, as much as 25 feet of space will be necessary to allow a spraying wagon and fixtures to pass in spraying the trees properly, and to place ladders about the trees for gathering the fruit.

"The stakes being set around the orchard ground at proper distances, the tape line is no longer needed, as the cross intermediate rows of stakes are to be set by sight. Now let one man take ten of the white-top stakes and go about to $\boldsymbol{E}$ (at bottom 
of cliagram, and another man go to the first stake north of $I$, and sight the man at $E$ precisely where to stick a stake in line with the two stakes on opposite sides of the ground; then move northward to 2, and stiek a stake between 2 and 2; and thus continue from south to north and from east to west, through and not far from the middle of the field, being careful not to place either of these intermediate rows where a row of trees is to be planted. These rows need not be straight, but each stake must be in line with the corresponding stakes at the right and left.

"With the stakes thus placed, a person moving anywhere about the ground to be planted ean readily find, by looking in the direction of two stakes in two directions at right angles, precisely where a tree is to be planted. Thus, a person standing at either + is at a point where a tree must stand, and at either of those points will see two stakes in a line with him in two directions at right angles; and so of every point where a tree is to be planted. If men are to be employed to dig the holes who are not capable of setting a stake in line with two other stakes already standing (there are such men), let some one who can do so go through the field, and with point of stake or other thing, mark where the holes are to lee dug.

"With this arrangement no stakes are placed where the trees are to be planted. Any number of men can go on with the work of digging the holes and planting in any part of the orehard without 
reference to any other trees in any other part. The writer has planted about 150 acres of apple and 100 acres of peach orchard on this plan, and has furnished many parties brief descriptions of same for planting; has planted rows 30 to 40 rods long of nice trees, so straight in line that a stake two inches in diameter set up in the row would hide every tree from view, looking from the end thereof."

Orchard plans.-Van Deman* writes fully upon the metlods of constructing a plan of an orchard, as follows :

"The hexagonal, Van Deman plan.-The plan that will best ceonomize space is what is known as the 'hexagonal' plan. It is a system of equilateral triangles, and is sometimes ealled the 'triangular' system. It puts all adjacent trees equally distant from each other. This is the plan I have followed in all my own plantings, and now think it the best I have ever seen. I have practiced upon the additional idea of planting temporary trees alternately with permanent ones, and leaving alleys between every fifth and sixth row, which I have never seen in any other orehards of the hexagonal style; therefore, I have called this part of it the 'Van Deman' plan. In the lower part of Fig. 33 it may be seen. By this plan there may be planted 156 trees per acre one rod apart, with every sixth row left out for an alley, which gives easy access to wagons for gathering fruit, and for any other necessity. The permanent trees are marked by the letter $P$ throughout this and all the other plans. These trees are two rods, or 33 feet, apart, which, for apple trees in most elimates and soils, is sufficient. In Michigan, Pennsylvania, New York and some other localities where apple trees

* H. E. Van Deman, "Plans for Orehard Planting," Rnral New-Yorker, March 6 and 13, 1897. Revised for this oceasion by Mr. Van Deman.

For tables giving the number of plants to the acre, see "The Horticulturists' Rule-Book," 4th ed., pp. 115-119. 
grow to very large size, 40 to 45 feet is none too far apart for Iermanent trees. The places for the temporary trees or, 'fillers,' are designated by the letter $F$. The fillers reduce the distance between trees to one rod, or $16 \frac{1}{2}$ feet, except where the alleys ocenr, which are $25 \% \frac{1}{2}$ feet wille. The fillers should be of early-

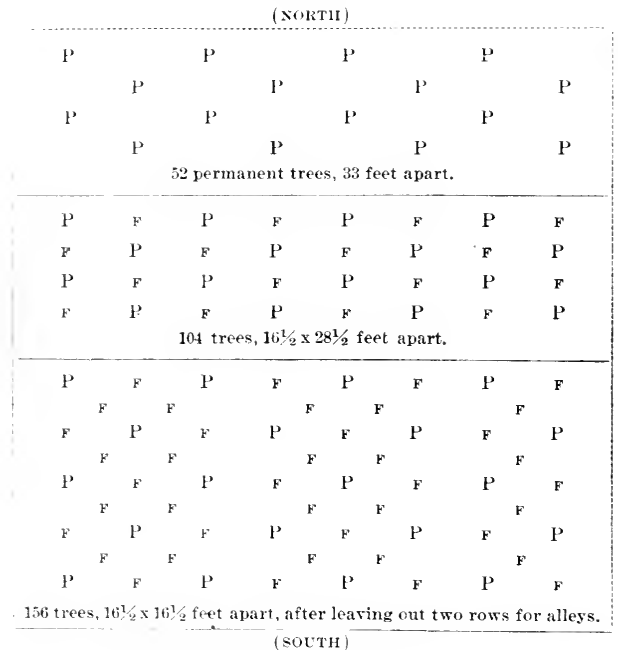

Fig. 33. Hexagonal plan.

bearing kinds, such as Wagener, Missouri or Wealthy, whieh will usually pay the eost of the entire orehard within the first ten years. In the middle section of Fig. 33 are 104 trees per acre, in which all the intermediate rows are left out, the fillers only equaling the permanent trees. These are preferably in the rows rumning north and south, that the trees may in some 
measure protect each other from the force of the prevailing southerly winds in the prairie states, especially; and some think from the hot sun, also. This is one of my favorite plans. It gives ample room to cultivate, and is just right for planting six rows of corn, which for the first five or six years is advis-

(NORTH)

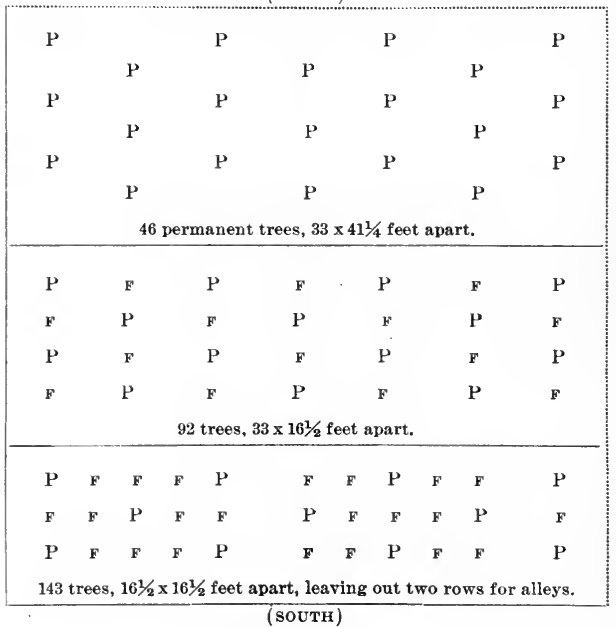

Fig. 34. Alternate plan.

able. The upper section of the diagram shows only the permanent trees, of which there are 52 per acre. The rows are $281 / 2$ feet wide three ways, and permit cultivating the trees accordingly.

"The alternate plan.-Fig. 34 shows the alternate plan, and is in all particulars like Fig. 33, except that the rows are fully 
33 feet apart, instead of $281 / 2$. The trees are to be planted alternately, just as bricks are laid in a wall. In the lower section there are 143 trees per aere; in the middle one 92 , and in the upper, fully thinned section, there are 46 permanent trees.

"The Wellhouse plan.-Almost every fruit-grower has heard

\begin{tabular}{|c|c|c|c|c|c|c|}
\hline \multicolumn{7}{|c|}{ ( NoRTH) } \\
\hline$P$ & $P$ & $\mathrm{P}^{\prime}$ & $P^{\prime}$ & $\mathrm{P}$ & $1^{\prime}$ & $P^{\prime}$ \\
\hline$P^{\prime}$ & $P$ & $P$ & $P$ & $\mathrm{P}$ & $l^{\prime}$ & $1^{\prime}$ \\
\hline$P^{\prime}$ & $\mathrm{P}$ & $P^{\prime}$ & $P^{\prime}$ & $P^{\prime}$ & $\mathrm{P}^{\prime}$ & $P^{\prime}$ \\
\hline \multicolumn{7}{|c|}{49 permanent trees, 32 feet apart. } \\
\hline F & $\mathbf{F}$ & F & $\mathbf{F}$ & $F$ & $\mathbf{F}$ & $\mathbf{F}$ \\
\hline $\mathrm{P}$ & $\mathrm{P}$ & 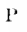 & $\mathrm{P}$ & $\mathrm{P}$ & $\mathbf{P}$ & $\Gamma^{3}$ \\
\hline $\mathrm{F}$ & $F$ & $\mathbf{F}$ & F & $\mathbf{F}$ & $\mathbf{r}$ & $\mathrm{F}$ \\
\hline $\mathrm{P}$ & $\mathrm{P}$ & $P^{\prime}$ & $\mathrm{P}$ & $\mathrm{P}$ & $P^{\prime}$ & $\mathrm{P}$ \\
\hline $\mathbf{F}$ & $\mathbf{F}$ & $\mathbf{F}$ & $\mathrm{F}$ & $F$ & $\mathbf{F}$ & $\mathrm{F}$ \\
\hline $\mathrm{P}$ & $\mathrm{P}$ & $\mathrm{P}$ & $P$ & $P$ & $P^{\prime}$ & $P^{p}$ \\
\hline$F$ & $\mathrm{~F}$ & F & $\mathrm{F}$ & $\mathbf{F}$ & $\mathbf{F}$ & $\mathbf{F}$ \\
\hline $\mathrm{P}$ & $P$ & $P^{\prime}$ & $P^{\prime}$ & $\mathrm{P}$ & $P^{\prime}$ & $P^{\prime}$ \\
\hline \multicolumn{7}{|c|}{98 trees, $32 \times 16$ feet apart. } \\
\hline
\end{tabular}

Fig. 35. Wellhouse plan.

of Hon. F. Wellhouse, of Kansas, who is ealled 'The Apple King of America.' Well may he be so ealled, for he and his son, who is in company with him, have over 1,600 acres of apple orchard, ranging from two to twenty-two years planted. His trees are planted $32 \times 16$ feet apart, in rectangular style, as shown in the lower section of Fig. 35, the 
wide spaces running north and south; this makes 98 trees per acre. The upper section shows the permanent trees in exact squares 32 feet each way, as is now the case in his older orchards that have been thinned, 49 trees standing on an acre. He has not mixed the varieties, as is indicated in

( NORTH.)

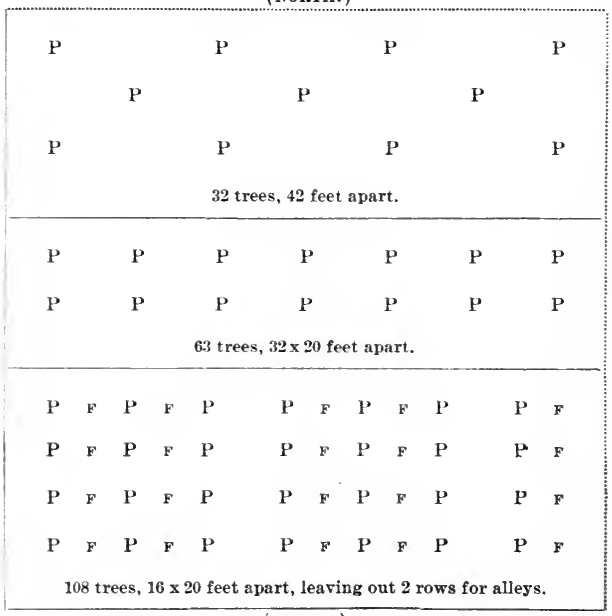

(SOUTH.)

Fig. 36. Parker Earle plan.

the illustration, so far as I know, but planted ${ }^{\circ}$ such varieties in solid blocks as would bear reasonably early; but it would seem to me that, if such kinds as Missouri were planted in rows between the others and to be removed, it would be better than planting each by itself. But, aside from his published statements of the results of his enterprise, I know, from a long 
and intimate acquaintanee with Judge Wellhouse and his orchards, that they have done remarkably well.

"The Parker Earle plan.-The plan originated by Parker Earle, who is one of the leading western hortieulturists, is slown at Fig. 36. He has planted several hundred aeres of apples after this plan in the famous Pecos Valley of New Mexico, where the trees eome into bearing very early. They are 16 feet apart east and west by 20 feet north and south, exeept that every sixth row is left out for an alley, as in the lower section of the diagram. There are 108 trees per acre. The intention is to eut ont every other north and south row, thus leaving them as shown in the middle seetion, $32 \times 20$ feet. There will then be 63 trees per aere. One-half of these may be taken ont later, if more spaee be needed, leaving at the rate of 32 trees per aere, 42 feet apart. This will give ample spaee when the trees get to be very large; but in that climate, and northward to Colorado, Ctah and Idaho, the trees are so preeoeious, and bear so abundantly, that it is doubtful whether they will ever attain size to need so much space.

"The Olden plan.-Who has not heard of the famous Olden Fruit Farm, in southern Missouri? I made three prolonged visits there to see it at different times of the year, and it is well worth seeing. The oldest parts of the apple orchards are just at good bearing age. It is planted mostly to apples and peaches, but there are a few pears, plums and small fruits. Each year more are added; last year 960 aeres were planted. J. C. Evans and L. A. Goodman are the leading spirits of the eompany that owns and runs it. Their plan for apples is $25 \times 25$ feet, in plain squares, and all of one variety in a block, making 64 trees per aere, as in the lower section of Fig. 37. The trees have not eome to the age that requires thinning by the ax, but they will do so in time, for apple trees grow to a very large size in that rich soil and agreeable climate. When it does come, they will take out every other diagonal row, leaving 32 trees per aere, $3 \pi \frac{1}{2}$ feet apart the nearest way (diagonally), and 50 feet east 
and west, as in the upper section. While it may seem presumptuous for me to suggest an improvement on a plan so well matured, and by such eminently practical orchardists, and, when it is true that the apple bears quite young and profusely in all that Ozark Mountain region, yet it does seem

(NORTH.)

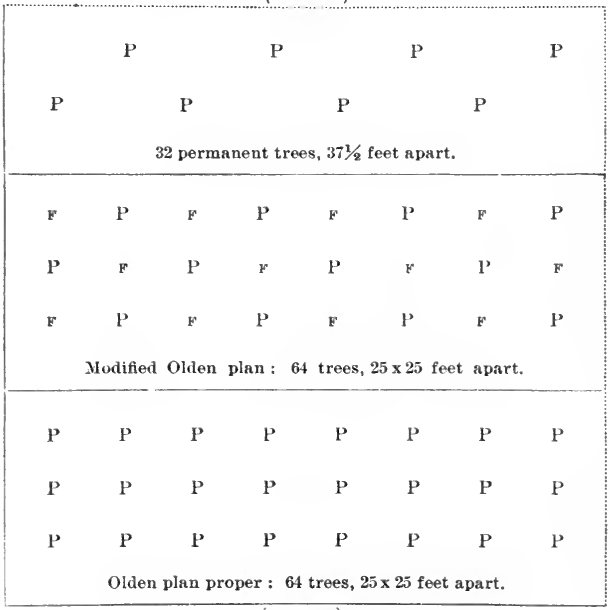

(SOUTH.)

Fig. 37. Olden plan.

to $m e$ that it might be well to mix the varieties in the row, filling in each alternate diagonal row with the earliestbearing varieties to be planted, and thus preparing for their removal and the retention of those of a less precocious and more durable character. This modified plan I have depicted in the central section of Fig. 37 . 
"Olden and Hale plans for peach orchards.-The Olden plan for a peach orchard is, to have the trees $16 \frac{1}{2} \times 16^{1 / 2}$ feet apart each way, and in plain squares, making 169 trees per aere, as in the lower section of Fig. 38. At convenient distances for the passage of wagons, roads are laid out, making ( NonTH.)

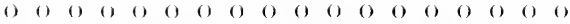

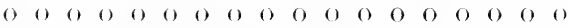

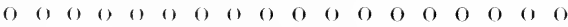

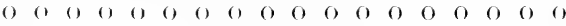

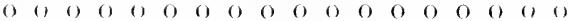

Hale plan: 209 trees per aere, $13 \times 13$ teet apart.

$\begin{array}{lllllllllllll}0 & 0 & 0 & 0 & 0 & 0 & 0 & 0 & 0 & 0 & 0 & 0 & 0 \\ 0 & 0 & 0 & 0 & 0 & 0 & 0 & 0 & 0 & 0 & 0 & 0 & 0 \\ 0 & 0 & 0 & 0 & 0 & 0 & 0 & 0 & 0 & 0 & 0 & 0 & 0 \\ 0 & 0 & 0 & 0 & 0 & 0 & 0 & 0 & 0 & 0 & 0 & 0 & 0 \\ 0 & 0 & 0 & 0 & 0 & 0 & 0 & 0 & 0 & 0 & 0 & 0 & 0 \\ 0 & 0 & 0 & 0 & 0 & 0 & 0 & 0 & 0 & 0 & 0 & 0 & 0 \\ 0 & 0 & 0 & 0 & 0 & 0 & 0 & 0 & 0 & 0 & 0 & 0 & 0\end{array}$

Olden plan : 169 trees per acre, $16^{1 / 2} \times 16^{1 / 2}$ feet apart.

( $\mathrm{OOTTH.)}$

Fig. 38. Hale and Olden plans for peach orehard.

a series of large blocks. The contour of the ground and intervening rocky hillsides or oak forests left standing, do not always permit these blocks to be of regular size or shape.

"Then, we have the great Hale peach orchards in Georgia and Conneeticut, and who has not heard of them and of 
their stirring Yankee proprietor, J. H. Hale, of Connecticut? He plants $13 \times 13$ feet, which seems extremely close, even for peach trees in Connecticut. As I walked through them with Mr. Hale, I repeatedly expressed such an idea, but he refuted it as often, gave favorable statements from experience, and then he would say, 'There are the trees; do they not look thrifty enough?' And I could not say but that they did. But he feeds them like a lot of pigs in a pen. He prunes them back to bearing, paying and convenient size. $\mathrm{He}$ is not growing peach trees for fuel simply; although they will go into the wood and brush piles whenever their day of usefulness is over, and others be planted in their stead. Streets are laid out both ways through his Georgia orehard of 600 acres, eutting it into regular blocks $1,000 \times 500$ feet in size. There are 289 trees per acre, as may be seen in the upper part of Fig. 38.

"The Delaware and Maryland peach orehards are set wider than those already mentioned. The trees grow to large size, and utilize the 16 to 20 feet space given them. The Michigan peach orehards are set somewhat closer, and those of the northern part of the peach belt along the lake are deeidedly so. I have visited all of these sections and examined the orchards, finding the square or hexagonal styles the most popular. In Texas and California I saw large, thrifty peach trees that needed as much space as any, and planted in the most exact manner, usually in squares or hexagons, at from 18 to 24 feet apart.

"The pear, cherry, plum and prune (some plums are ealled prunes, especially in the Pacific states), taking the country over, are all subject to the same conditions and variations of elimates and soil as the apple and peach, and, like them, they ean properly be planted in any of these styles mentioned, the distances being ehanged to suit each. The pear, being an upright grower, as a rule, does not need so much room as the apple; 20 feet apart is a common distance to plant standards, and 10 to 12 feet for dwarfs. The Kieffer, Le Conte and Garber bear very early as standards, and may 
be planted about 16 feet apart, and thinned out as they erowd each other.

"The sour eherries need abont 18 to 20 feet, while the larger-growing sweet varieties require fully 20 feet, and in time, if they are not pruned back severely, 40 or more feet when they attain their full size. Plum orehards should vary

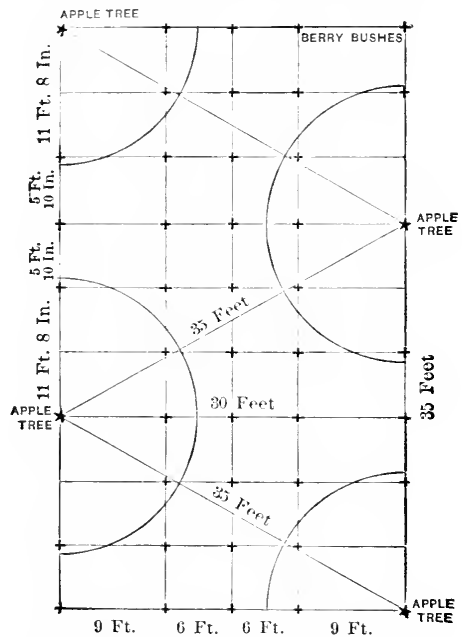

Fig. 39. Setting small-fruits in an orehard.

somewhat in eloseness with the varieties planted. The great prune orehards of the Pacifie slope are set with about 20 feet between the trees. The orehards of our native speeies require about the same room; but the Japanese class is usually more upright in growth, and may be planted a little closer." 
Hutt describes* the following method of planting small-fruits in an orchard: "The bushes were ar10 RODS.

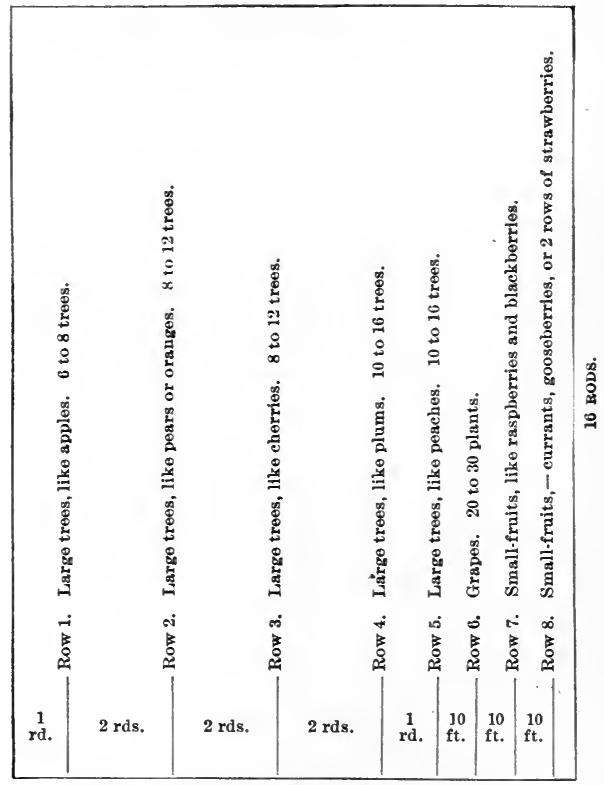

Fig. 40. Suggestion for a fruit garden of one acre.

ranged so that eultivation may be given both ways with a minimum amount of hand hoeing. The ac- 
companying plan (Fig. 39) shows the arrangement of the trees and bushes. The trees are planted on the hexagonal plan, the rows being 30 feet apart and the trees 35 feet apart in the rows, the trees in one row alternating with those in the next. By this method of arrangement, 15 per cent more trees can be planted to the acre than by the ordinary method, and yet not be any more crowded. The bushes are 6 feet apart one way by 5 feet 10 inches the other. At present no trees are nearer than 9 feet to the apple trees. As the trees inerease in size, those bushes within the circles, as shown on the plan, will be the first to be removed."

The family fruit plantation.-It is impossible to give any specific adviee for the plan of a family fruit garden, beeause tastes are so personal, and the amount and character of land at the disposal of the party are so various. One can only say that the varieties should be chosen for best dessert and culinary qualities, for succession through the season, and that the area should be so planted that the rows run the long way of the land and to allow of easy cultivation with a horse. In general, it will not be necessary to provide for eultivation both ways. The accompanying diagram (Fig. 40) suggests how an area of one aere may be laid ont in a fruit garden for the home supply. For a number of years, other plants - as vegetables, small-fruits, or dwarf apples or dwarf pears - may be grown, not only between the rows, but between the trees in the row. 


\section{CHAPTER VI.}

THE SECONDARY AND INCIDENTAL CARE OF THE FRUIT PLANTATION.

THE methods of tilling the fruit plantation have been fully considered in Chapter III., but since the subject is so important and so commonly misunderstood, it may be well to repeat two or three of the advisory suggestions at this place. There are many persons who fully believe that elean tillage is the proper treatment for an orchard, but who are debarred from putting the matter into practice because of the great amount of labor which they conceive to attach to it. As commonly practiced, it is certainly true that the tilling of orchards is one of the most laborious duties of the farm, but this is because the accustomed methods are wrong or bungling. The orehardist rarely has the land fully under his control. The essence of the whole matter is to get the land in ideal condition whilst the orchard is young, and then to practice surface tillage (with only occasional plowings) after the trees begin to bear. The use of modern implements makes it easy to keep the land clean without resorting to the high trunks of the old-time orchards. If the roots are made to strike deep into the land by deep plowing for the first 
few years, it may not be necessary to turn any furrows in the plantation in later years, except to turn under cover crops.

All this can be done even with hard clay land. The writer has the management of two orehards upon very hard clay of uneven surfaee, which, in six years from the setting of the trees, is in sueh condition that deep plowing is no longer neeessary, and the spring fitting of the land is done with spading harrows and spring-tooth harrows, and the subsequent tilling is partly done with a spike-tooth harrow. Weeds are not allowed to appear; but if a patch should get a start now and then, it ean generally be destroyed with the eultivator. Perhaps once or twice during the season it will be necessary to send a man through the orehard with a hoe to take the weeds away from the trees, but the space which needs such hand labor will not exceed two feet in diameter, and it is usually very much less. This has been aeeomplished by exercising great eare to plow the clay when it is in such condition that it pulverizes when it is worked, and by the incorporation of one or two eover crops. It will be necessary now and then to put eover erops on the land for the purpose of adding humus, and the land will then be regularly plowed in spring to turn the rrop under; but even then it may not be the desire to secure a heavy growth of cover erop, and the spring plowing need not necessarily be deep and laborious. If, however, it seems to be necessary to plow six or eight inehes deep, there will be no 
hesitation in doing so, for the roots are deep enough to escape the plow if the plowman is ordinarily careful about the trees.

It is not necessarily a misfortune to cut the smaller roots of plants with the plow, providing only a few are cut in any year. In other words, it is no doubt safer to sever a good many roots a

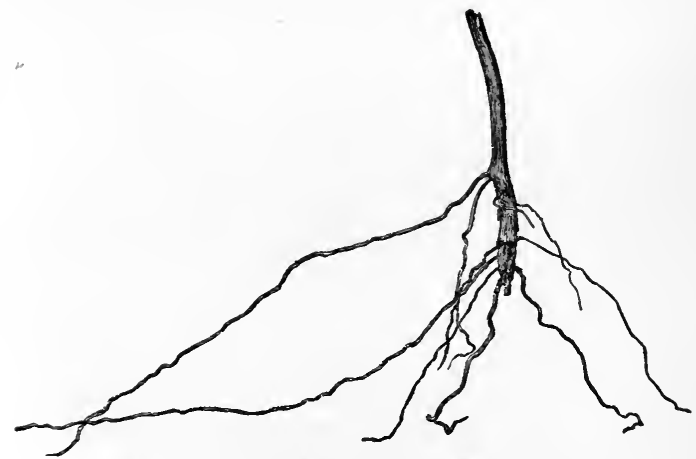

Fig. 41. A broken grape root sending out branches.

half inch, or sometimes even an inch, in diameter, than not to plow the orchard at all. The severed roots generally send out numerous branches near their ends, and these branches increase the foraging power of the root in soil which is normally laid under small tribute. Figs. 41 and 42 are drawn from actual specimens of roots which were broken by the plow. It would seem as if the absorbing 
area of the root had been actually increased, for the many small roots certainly present more surface than the main shaft of the root did. It must be remembered, however, that the real surface of the original root extended far beyond the present point, and there is no way of telling if the adventitious roots actually present more surface than the whole of the original root did. But it is probable that an ocea-

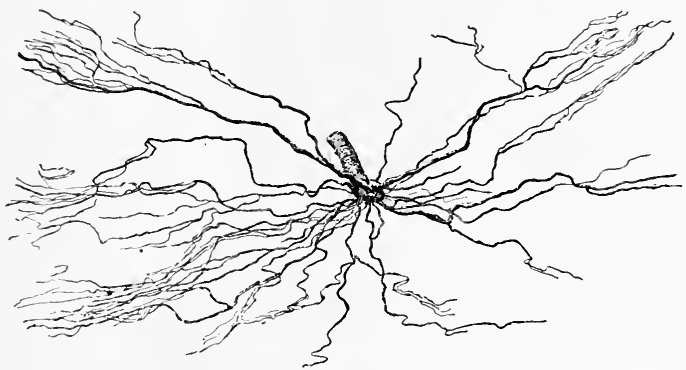

Fig. 42. Showing the numerous adventitious branehes of a broken apple root.

sional light root-pruning may do more good than harm in some cases.

The particular methods of caring for plantations of small-fruits can scarcely be discussed in a general work on fruit-growing, but in general it may be said that a deep cultivation with a spring-tooth (ultivator (No. 9, Fig. 13, page 147) is usually suffirient for breaking up the ground in spring amongst bush-fruits, if the land is clean and in good cou- 
dition. If the land is soddy or infested with bad weeds, however, a regular plowing may be necessary. A handy plow for such plantations is one of the type shown in Fig. 16, page 158, managed by a single horse. The management of the land in small-fruit plantations does not differ in prineiple from the management of orchard lands, and the tools are of the same general kind, except smaller and generally adapted to a single horse. If the rows are far enough apart, however-as they usually are in blackberries and black raspberries-it may be necessary in hard lands to hiteh two horses to such a tool as the spring-tooth cultivator.

It is scarcely necessary to repeat that it is essential to give the fruit plantation just as good tillage as the corn receives, if equally good results are desired. Wholly aside from the direct benefits of tillage (which have already been explained), the operation is necessary in order to supply the enormous quantities of moisture which are exhaled from the leaves of the plants. Professor Burrill, of the University of Illinois, estimates* that a good-sized apple tree, having 25,000 square feet of evaporating surface, which is not a large estimate, will give off 31,200 ounces of water per day in the hot season, or say 250 gallons.

It is generally a matter of a few years to thoroughly learn one's soil and climate, after moving onto a new farm. The farmer has a local and per-

* Trans. Ill. Hort. Soe. 
sonal problem to apprehend and to solve. He should not be discouraged, therefore, if he does not seeure the desired results from the treatment of his land within the first two or three years.

THE GENERAL CARE OF THE PLANTS.

Staking young trees. - If fruit trees are stocky and well planted, and if the land is deep and in good condition, it will rarely be neeessary to stake them. The staking of an orchard is generally an indication of poor trees or poor management at some point. It oceasionally happens, however, that trees must be staked to enable them to overeome some aecident or injury, as breaking by heavy winds, or iee, or other means. When it is necessary to stake trees, it is ordinarily preferable to drive a stout stake npon two sides and then to bind the tree firmly to each of these stakes, in order to keep it from whipping. The best bandage is one of burlaps or other strong, soft eloth, ent in strips two or three inches wide and firmly tied about the tree. Inst as soon as the tree has recovered from its injury or weakness, the support should be removed. Trees whieh have blown over, bnt whieh have not been broken completely off, may be severely headedin and tied up in this manner, often with the very best results. The wounded and broken surfaces shonld be thoronghly covered with some antiseptic wash or paint.

Sun-scald.-It is often necessary, especially in 
the hot plains regions, to shade the trunks of young trees in order to prevent sun-scald. In the nursery rows, the bodies of the trees are ordinarily well shaded. There are various means of providing this shade, but the best results may be expected to follow from some protection which simply breaks the force of the sun and does not entirely obstruct it; for in the latter case, the bark does not so readily become inured to exposure to sunshine. Finely woven wire netting rolled around the tree (in more than one thickness, if necessary), is said to afford very good protection for this purpose, as shown in Fig. 43 (but preferably extending higher up the trunk). The upper part

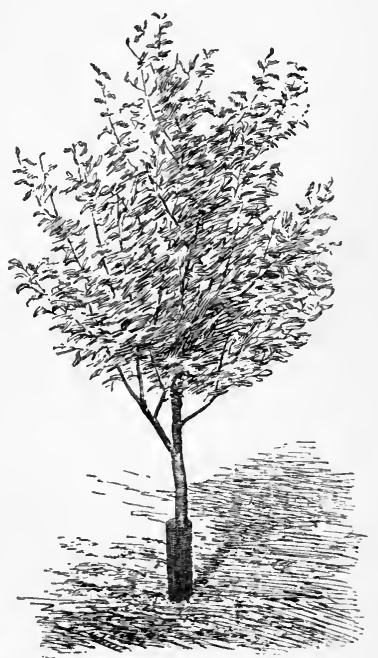

Fig. 43. Tree protected by a roll of netting. of the trunk is likely to be shaded sufficiently by the branches of the tree, although this is not always the case. These rolls of wire netting also serve a purpose in keeping away mice and other vermin. 
Hansen* writes as follows upon this subject for Dakota conditions: "Sun-scald causes great loss in northwest prairie orehards. By sun-scald is meant the alternate thawing and freezing of the stem on the sonthwest side in late winter, causing the bark to die and decay. Oftentimes the dead, blackened bark separates entirely from the stem. Orchardists now generally reeognize the cause of the trouble, and prevent it by shading the stem in some way. Trees planted and kept with stem leaning toward the sonthwest until the branches shade the trunk, are free from it. Some fruit-growers set a board, or two boards nailed together trough-fashion, on the southwest side; others use eorn stalks, wire netting, or lath. Low-headed trees are best for severe loeations; in more favorable sections trees may be headed two-and-a-half to three feet high. Tall trunks suffer more from sun-seald and serere winds."

Trees are apt to suffer with sun-seald after a heary pruning, especially if they have been allowed to grow too thick in the first place. Cutting out heavily from the center of the tree exposes the oblique and horizontal limbs to the intense heat of the sun, and the bark is likely to blister and be killed, after which borers are very apt to finish the work of destruction. In all interior hot regions, therefore, it is well to exercise caution in the pruning of the tops of trees. It is better to keep the top

* N. E. Hansen, "Fruit Culture," Bull. 50, S. Dak. Exp. Sta., 1897. 
somewhat thin and open from the start, rather than to allow it to become overgrown and then to make a sudden and radical correction of the difficulty.

Bark-bound trees.-When a tree has been allowed to become stunted for two or three or more years, it is likely to become hide-bound, so that growth is impeded, even though the care of the plantation be corrected. The bark becomes very thick and dense and tight, and is likely to be dull and lifeless in color and sometimes moss-covered. The newer and fresher parts of the tree are likely to show a tendency to overgrow the lower parts which are hide-bound. In all such cases, the bark should be softened so as to allow the trunk to expand. In general, the best means of loosening up the bark is to scrape off the outer hard layer, if it should become mossy or entirely dead, and then to wash the tree thoroughly with some soapy compound. This washing should be done with a broom, or preferably with a strong scrubbing brush, so that the body may be vigorously scrubbed. A wash of strong soapsuds is very good. Tar soap, whale-oil soap or carbolic soap are also very useful for the purpose.* These washes have the effect of softening the bark and allowing the tree to grow more readily. The effect of a good wash upon orchard trees is often exceedingly marked. It is sometimes thought by orchardists that the potash in these washes is absorbed through the bark, and thereby stimulates the tree. It is probable that it

* The reader may find varions recipes for washes in "The Horticulturist's Rule-Book." 
eventually becomes plant-food by being washed off onto the soil, though the chief value of the wash is no doubt the softening and loosening effect which it has on the bark.

Another means of releasing the pressure upon hide-bound trees is to slit the bark the entire length of the trunk or hide-bound portion. This is done by simply thrusting the point of a knife through the bark until it strikes the wood, and then drawing the blade down the entire length of the portion to be treated. When the knife is withdrawn, the slit is scareely visible; but after a time the slit widens, as the tree begins to expand. This method is to be advised only as an extreme resort, for it is better to keep the bark fresh and elastic by good tillage and by the use of washes; but the slitting is of no damage to the tree, as a rule. The washing also has the additional advantage of killing various insects and their eggs which may be in or about the bark. Spraying with Bordeaux mixture will kill the lichen or "moss" on the trunks.

Scraping trees.-The onter layers of bark of any tree gradually die and peel off, as the tissue grows upon the inside. This old, rough bark is of no direct use to the plant, but it probably affords some protection to the tender tissues within. It also affords a lodgment for insects and fungi. Trees which are kept in a good condition of growth and which are watehed carefully, will need very little attention in the removing of the bark, but if the shaggy bark aecumulates to any great extent, it is well to scrape 
it off. The operation should be done when the warm weather approaches in spring, or, in fact, at almost any time in the growing season. A good tool for this purpose is an old and thin hoe, the handle of which is eut down to about two feet in length. This tool is grasped lightly in the hand and is raked up and down the tree, and it removes the rough bark with ease. The very best tool for the purpose, however, is that shown in Fig. 44, which is a steel plate with sharp, ground edges, fastened securely to a bent shank. This tool can be had of harōware dealers, to whom it is known

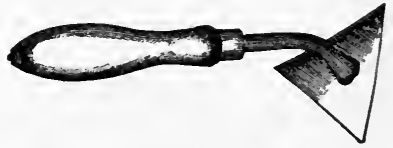

Fig. 44. Scraper for cleaning and repairing trees.

as a box-scraper.

Aside from removing the loose bark from the trunks of trees, this tool is very useful in cutting out and removing all diseased spots upon the bodies or in the crotches. The wounds resulting from the barking of trees may be trimmed down to fresh tissue by such a tool, and all spots injured by bark borers, spots of pear-blight, patches of canker, and the like, may be cut away, and the wounded surfaces are thereafter covered with Bordeaux mixture or paint. In the scraping of trees, it is always advisable to take away every particle of wounded and diseased tissue, unless it extends deep into the wood. When the object is to simply take away the rough and loose bark, the tree should not 


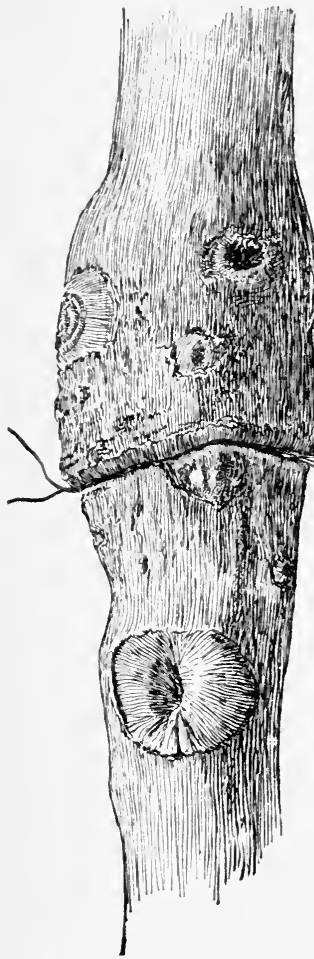

Fig. 45. A young trunk girdled by a label wire.

be scraped down to the quick; that is, only the loose exterior portion should be re moved.

Girdled trees, and girdling.-Trees which are girdled should have the injured parts pared down to live tissue and the wounded surface then covered with an antiseptic dressing. It is also advisable to bind up the girdle with some material like grafting-wax, which will keep the wood moist and thereby allow the ascent of the sap; for the sap rises in the tree through the young, soft wood, and not between the wood and the bark. The bark is formed over the wound by the sap which is redistributed through the tree after it has been elaborated in the leaves; that is, the reparative tissue is formed by elaborated sap which is on its downward course. If the woody tissue is kept soft and fresh, the tree may continue to live for years, but there will be a deposition 
of woody matter above the girdle, whilst the portion below will not increase in diameter. This is well known to all observing fruit-growers. Fig. 45 shows a deposit of woody matter above a girdle caused by a label wire. After awhile the younger wood is apt to become hard and dry, preventing the upward passage of nourishment taken in by the roots, and the tree then starves to death; or, as in the case of the young tree shown in Fig. 45, the top may become so heavy that the plant breaks off at the point of constriction. It is, therefore, evident that it is very necessary that the orchardist give careful attention to his label wires, to prevent them from doing great injury. It is always best to take the labels from young trees when they are set, and to depend upon a map record for the names of the varieties. Or, if the label is left upou the tree, it is best to hang it upon one of the minor limbs, rather than upon the trunk. In adjusting the label wire to the tree, it is important that only the ends of the wire be twisted together, allowing thereby a large loop in which the limb may expand. The label may be held tightly to the limb by simply pinching the wires together with the fingers.

Trees which are freshly girdled in the growing time of spring may be expected to heal over before the season is over, if the girdled zone is not more than four or five inches wide, and if the surface of the wood, as already explained, is kept perfectly fresh. It is generally best, however, if no connection of bark remains, to bridge over the girdle by 
cions. These cions are of the same kind as those which are used for ordinary grafting. The edges of the girdle are pared down to fresh wood, and the cions are eut two or three inches longer than the width of the girdle. They are whittled to a wedge shape upon either end, and these ends are inserted between the bark and the wood upon the upper and lower sides of the girdle. They should be so numerous as to almost tonch each other entirely aromud the tree. After they are inserted, a strip of eloth should be bound tightly upon the bark over their ends, and the whole girdle should then be waxed over. It is a good plan to pour melted wax over the work, allowing it to run in between the cions and cover the edges of the bark and the exposed surface of wood.

The congestion of the parts of the plant immediately above the girdle shows that those parts are overfed; that is, they receive nutriment at the expense of the portions below the girdle. It would seen, therefore, that girdling might be made to increase the size and hasten the maturity of fruit which is borne beyond the girdle; and such is known to be the case. The girdling of grapes is al common practice in some regions. The girdled portions are entirely removed in the next anmual pruning, and enough of the growing portion is left below the girdle to maintain the roots and trunk. It will be seen, therefore, that the liability of injury to the vine is all a question of how mueh is left below the girdle and how much above it. 
Careful vineyardists are able to continue the practice year after year without apparent injury to the vine. The girdling is done when the grapes are about the size of peas, and a section of bark about an inch wide is entirely removed from the eane. A gain in earliness of a week to ten days may be secured by the process, but it is commonly believed that the quality of the better grapes is injured. As a matter of practice, only the very earliest varieties of grapes are girdled or ringed for commereial purposes; and it is doubtful if the practice is to be commended.

Apples and other fruit trees are sometimes ringed to set them into bearing. "Many orchards develop a habit of redundant wood-bearing, and these are often thrown into fruiting by some check to the trees, as seeding down, girdling, and the like. Probably every orchardist has observed that the attacks of borers sometimes cause trees to bear. It is an old maxim that checking growth induces fruitfulness. This is the explanation of the fact that driving nails into plum and peach trees sometimes sets the trees to bearing, and also of the similar influence exerted by a label wire which has cut into the bark, or of a partial break in a branch. Girdling or ringing to set trees into bearing is an old and wellknown practice. It is not to be advised as a general resort, but I should not hesitate to employ it upon one or two of the minor branches of an unprofitable tree for the purpose of determining if the tree needs a check. I saw a Baldwin tree this year in which 
two large limbs had been girdled last year, and these limbs were bending with fruit whilst the remaining branches and the adjacent trees were barren. Girdling may generally be done with safety in spring, when the leaves are putting out. A ring of bark two or three inches wide may be removed elear to the wood, and entirely encircling the limb. I have heard of excellent results following the simple ringing of trees, which consists in severing the bark-but removing none of it-completely around the tree with a sharp knife, in spring. These are, of course, only incidental operations, to be employed with caution, and then only upon branches of less importance. Their value is wholly one of experiment, to aid the owner in determining what fundamental treatment the orchard probably needs." *

Pruning and heading-in.-The subject of pruning cannot be understood until the fundamental principles of the practice are clearly apprehended. It is, therefore, well-nigh useless to state any general rules or precepts for the pruning of trees in a work like the present. It is only necessary to say that a heavy pruning upsets the habit of the tree, and generally sets it into the heavy production of wood for a time. The only proper pruning is one which is applied in something like the same proportion every year, and which begins the very year in which the plants are put into the ground. Trees which are alternately neglected and heavily pruned are kept in a condition

\footnotetext{
*Bull. 102, Cornell Exp. Sta., 519 (Oct., 1895). A fuller discussion of ring. ing may be found in "The Pruning-Book."
} 
of unrest which is apt to be fatal to the best productiveness.

The question of heading-in of trees is one which is commonly misunderstood, and upon which there is the greatest demand for information. It is impossible to give any dogmatic statements as to whether the operation shall be practiced or not. There are two or three considerations which the grower should chiefly bear in mind, which may help him to think out the problem for himself. In the first place, it is largely a question of the type of training which the grower prefers: that is, every good fruit-grower will set before himself a certain ideal type or form of tree, and he will bend all his energies uniformly and consecutively to the working out of this idea throughout all the years of the plantation. If his ideal is for trees which shall have round and dense heads, then he will, of course, head-in the stock from year to year; if, however, he sets for himself the ideal of a tree with the natural form and open head, he will not head-in, as a rule. Whichever purpose the grower sets in his mind should be worked out systematically and logically from first to last. The other factor which chiefly determines the question of heading-in is that of redundant growth whilst the plants are young. As a rule, young trees grow more thrifty and upright than old ones do, and the grower should, therefore, not be misled into thinking that his trees will keep up their present pace after they have come into maturity and bearing. Kieffer pears, for example, make a very tall and narrow 
growth for the first two or three years, but when the bearing time arrives, this enormous growth is rhecked and the tree spreads. However, in such ases, it may be advisable to head-in the tree for a time, or until the period of maturity begins to arrive. It should always be borne in mind, however, that this heading-in is not the fundamental corrective of the difficulty; in fact, it rather augments it. It is a question, therefore, if it is not better to prevent redundant growth by withholding tillage and fertilizers, rather than to produce it and then to take it off.

IVinter preparations.-In winter, plants are exposed to injuries of wind, snow, water, ice, mice, rabbits, and the like. Before the season closes, the farmer should see that young trees stand stiff and straight, and in order to keep them rigid and to afford good surface drainage, it is sometimes well (especially with newly set trees in cold climates) to bank up the trees with earth to the height of six or eight inches. In making the bank, the workman should be cantioned not to leave holes, from which the earth is taken, close about the tree, for the water is likely to stand in them, and it may do harm. In small-fruits, grapes and nursery stock, it is often advisable to plow a furrow to the plants, upon either side, in the fall. Care shonld be taken to provide for top drainage if the conformation of the land is sueh as to hold surface water.

$A$ word should be said respecting the protection of trees from mice and other vermin. Mice and rab- 
bits injure trees chiefly in cold winters, when the amount of green food is scarce. They are apt to be especially bad in new countries. The best preventive of injuries from mice is to see that there is no material, as dead grass or weeds, close to the base of the tree, in which the rodents ean nest. If the litter is not taken away, it should at least be tramped down tightly before winter sets in. The best preventive of injury by rabbits is not to have the rabbits. If the brush piles and old fence-rows, in which the animals harbor, are cleaned away, there will commonly be little trouble; and, at all events, a smart boy who is fond of hunting will ordinarily solve the question without help.*

If mice are very serious, it may be advisable to put cylinders of wire netting about the trees, as already recommended. Rolls of birch bark are sometimes used in regions where the paper-birch grows. It should be borne in mind, however, that such covers for the bodies of trees interfere with clean culture about the base of the tree, and they are apt to afford a most excellent place for the lodgment of borers and other insects. The common notion that wire screens, and tarred paper, and mounds of ashes, and the like, prevent borers from working, is unfounded, and is, in fact, likely to be the very opposite of the truth; for a wire screen, which soon fills with grass and litter, is a most inviting place for the congregation of insect life.

\footnotetext{
*Various washes and other devices for preventing the injuries by mice, rabbits and gophers may be found in "The Horticulturist's Rule-Book."
} 
Depredations of stock and birds.-Injuries of trees can be prevented in sheep pastures and hog pastures by giving the animals plenty to eat and especially plenty to drink. They are very likely to gnaw the trees for the moisture which they secure. If, however, the animals begin to injure the trees, the only recourse is either to take them ont or build wide racks about the trunks; but any sort of rack or fence about the tree prevents the proper care of the tree.

The incursions of birds upon eherries and smallfruits ean usually be prevented by planting in sufficient quantity that the birds may get their fill without ruining the plantation. Cherry orchards may sometimes be protected by planting a number of trees of very early sweet cherries around the outside of the plantation. These will be sufficient to satisfy the birds. In some cases, however, it is impossible to save the fruit unless fire-arms are used; but it is usually sufficient to fire blank cartridges a few times to scare the birds away, and thereby obviate the necessity of killing them.

Sinall trees and garden plats of small fruits may also be protected from birds by means of netting which is now manufactured in this country for that purpose. Troop reports* as follows upon an experiment in this direction :

"The past season we had several varieties of the Russian cherries which were fruiting for the first time, and wishing to test the practicability of cov-

*James Troop, Bull. 53, Indiana Exp. Sta. 125 (1894). 
ering trees as a protection from birds, we procured from the American Net and Twine Co., of Boston, Mass., several hundred square yards of bird netting, and a part of the trees were covered with this just before the fruit began to ripen.

"Three trees of the Bessarabian variety were standing together in the same row, all well loaded with early fruit. Two of these were covered with the netting and the third left exposed. When the fruit on the covered trees was ready to pick, the exposed tree was completely stripped of every cherry, thus showing what the result would have been to the others had they not been protected. The question has often been asked: Will it pay?

"As already stated, the trees were young, having been set but six years. Each tree bore a half bushel or more of fine fruit this year, which sold for eight to ten cents per quart. The trees were of the roundheaded type, about ten feet high, so that the labor involved in covering was comparatively slight. The amount of netting required for each tree was about seventy-five square yards, which cost four cents per square yard. As soon, however, as the fruit from these early trees was gathered, the netting was transferred to later varieties, and the same process repeated. So that when the experiment was completed the account stood as follows :

To 75 yds. netting at 4 cents..$\$ 3.00$

$\overline{\$ 3.00}$
By 16 qts. of cherries at 10 cts. . $\$ 1.60$

" 18 " " " " 8 " 1.44 
"It will be seen that in this experiment the ac(ounts nearly balanced at the end or the first year. With careful handling this netting will last ten years or more; so that the question-will it pay to use it? - will depend largely upon circunstances. Judging from our own experience the past season, where, in testing varieties of fruits, it becomes absolutely necessary that the fruit should remain on the tree until fully ripe, there seems to be no question about the expediency of covering the trees."

Top-grafting bearing trees.*-One of the important factors in the secondary eare of an apple orchard is the grafting over of old trees or of worthless varieties. It is often asked if it will pay to graft trees after they are fifteen or twenty years old. The answer depends entirely upon how profitable the trees are in their present eondition. If they are bringing in no return, then nothing can be lost if they are grafted; and if the trees are strong and healthy, there is no reason why much should not be gained. If the operation of top-grafting is properly done, the trees ought to be completely changed over to a new variety in three or four years. It shonld be said, however, that the careful fruit-grower will find out whether his trees are to be profitable or not long before they reach the age of fifteen years. Trees which have arrived at that age before the owner has found out whether they are useful or not, are those which advertise an indifference or

\footnotetext{
* For advice respecting the topworking of young trees, see pages 234,235 .
} 
neglect of the owner. Even with apple trees, the orchardist should be able to tell within ten or twelve years after they are set whether the trees are likely to be profitable or not, and if there are strong indications that the varieties are unsuited to his needs the sooner they are grafted over the better. In grafting over the top of an old apple tree, it should be borne in mind that it is at the best a harsh operation, and that the top should be replaced as quickly as possible. In other words, the effort should be made to graft only limbs of comparatively small size (say not more than an inch and a half in diameter, and preferably less), and to set very many cions, even if some of them need to be cut out after two or three years. The setting of so many cions is somewhat expensive, but the orchardist should be able to do the work himself. Finally, it should not be expected that an old tree which is remodeled by top-grafting shall be of as good and handy shape as one which has been grown right from the start. (See Figs. 127, 128, 129, "The Nursery-Book," third ed.)

Thinning the fruit.-The thinning of fruit for the purpose of improving that which remains is a practice which is always advised, but comparatively seldom followed. It has been demonstrated time and time again that no work in connection with a fruit plantation pays better than this thinning. It not only results in a much finer product, but it is also a means of destroying the insect-infested and diseased specimens, and of saving the energies and vi- 
tality of the tree. Persons eomplain that the thinning of fruit is expensive and laborious, and this is true; but it is a fair question if there is anything worth the having of which the same may not be said. If the operation pays, then there is no exense for not performing it. It should be considered, also, that the fruit must all be picked sooner or later, and it really does not cost very much more to pick it early in the season than to pick it late; in faet, much fruit which is not worth pieking in the fall might have been eminently worth the labor if the trees had been thinned in the early summer.

There are two general methods of thimning fruits: One is a matter of pruning, by means of which the superfluous branches, or even the fruit-spurs themselves, are removed; the other is the direct picking of the redundant fruits. There is no reason in the nature of things why trees should not bear every year; but the formation of the fruit-spur is usually such as to preclude the production of fruit upon the same spur every rear. The philosophy of the thinning of fruit, therefore, is that one spur shall bear one year, and another spur the next. This means that when fruit is thinned, it should be the object to remove it wholly from some spurs in order that they may produce fruit-buds for the following year. In those regions where certain fruits are systematically thinned; the crop is obtained with great uniformity every year. This is especially true of peaches along the Miehigan lake shore, and in other places where this important fruit is well cared for. There 
is no reason why the same should not be said of other kinds of fruits, and for every fruit region.

There have been no long-continued and systematic experiments upon the thinning of fruits in this country. One of the best investigations which has yet been undertaken was in connection with the State Experiment Station at Geneva, New York, under the direction of S. A. Beach in 1896. These experiments were made upon full-grown apple trees, and the following extract* details the methods and the results :

"Trees of the same variety, as nearly alike in all respects as could be found, were paired for comparison, one of each pair being thinned, the other left unthinned. Three ways of thinning were tried:

"First.-All wormy, knotty, or otherwise inferior fruit was removed, and all elusters thinned to one fruit.

"Second.-Same as first, and remaining fruit thinned so that the apples were not less than four inches apart.

"Third.-Same as first, and the remaining fruit thinned so that the apples were not less than six inches apart.

"The sixteen trees which are included in the experiment belong to three varieties, namely: Rhode Island Greening, Baldwin, and Hubbardston. The Baldwins were most heavily loaded last season, and gave the most marked results in favor of thinning.

"With the first method Baldwin, thinned, gave

*Proc. W. New York Hort. Soc., 1897, p. 75. 
16 per eent less fruit, but about 10 per cent more No. 1 fruit than did the unthinned Baldwin. With the second method Baldwin, thinned, gave 26 per cent less fruit and about 22 per cent more No. 1 fruit than did the corresponding trees which were not thimmed.

"With the third method, Hubbardston gave 25 per cent less fruit, but about 17 per cent more No. 1 fruit than did the unthinned Hubbardston.

"The Greenings were very heavily loaded in 1895 , and in 1896 they bore a good crop, but were not overburdened, and needed comparatively little thinning. They were thinned according to the second method, and gave 6 per cent more fruit and about 10 per cent more first-class fruit than the trees did which were not thinned.

"In all these tests the picked fruit gave about one bushel of culls where the fruit was thinned, to three bushels where it was not thinned. Where the fruit was thimned the "drops" were fewer and considerably better, and in all grades the fruit was clearly superior in size and color to fruit of the same grade which was not thinned. The first grade included no apples less than two and one-half inches in diameter, and the proportion which measured two and one-half inches was a great deal larger where the fruit was thinned than where it was not, so that No. 2 apples from trees which were thinned were much superior to the No. 2 fruit from trees not thinned. Mr. Wilson [in whose orchard the tests were made] estimates that the fruit from the trees which were 
thinned would generally bring 10 per cent to 15 per cent more in market than the same grade from trees which were not thinned. According to these results, the second method of thinning is enough superior to the first to more than pay for the extra work involved. The second and third methods cannot well be compared from the data now at hand."

Maynard reports* experiments in thinning apples and plums, from which there were marked gains. To thin "full-sized" apple trees cost from 35 to 48 cents. In plums, "a distinct advantage gained by thinning is the appreciable decrease in the ravages of fungous diseases, and to a small extent, of insect pests. This is especially noticeable in the case of monilia, or brown fruit-rot, which often ruins the peach or plum erop in wet seasons, while the specimens of fruit attacked by the curculio were largely removed in thinning."

Tests have been made in a small way in the thinning of small fruits by elipping off the ends of the clusters. Halsted reports $\dagger$ as follows upon such a test: "Some experiments were made here [New Jersey Experiment Station] last year with eurrants, by removing the lower half of the flower elusters with a pair of scissors. It is a well-known fact that only a few of the berries of any cluster usually mature, and the free end of the stem becomes dead before the fruit is ripe. By the removal of this

* Bull. 44, Mass. Hatch Exp. Sta. (1897).

† Garden and Forest, iii. 19 (Jan. 8, 1890); also, Rept. N. J. Exp. Sta., 1889, 231. 
portion before the flowers upon it lave opened, it was hoped that there might be a larger and better fruit prodnced upon the remaining portion of the cluster.

"In the experiment, alternate bushes in a row were treated with the scissors, and in passing it may be said that this method of thinning ean be done rapidly. When the fruit was ripe, the whole product from an average bush, of the clipped and of the unclipped plants, was picked and spread ont upon tables. Judges ignorant of what had been done were then ealled in to inspect the results. No one failed to notice at once the difference, and all pronounced in favor of the fruit that had been treated, The berries were larger and of more nearly uniform size and ripeness. Two hundred berries were next removed from the uncut clusters, and it required thirty-five elusters to furnish this number. They weighed, elear of all stems, one hundred and fiftytwo grams. The same number, furnished by thirty clipped clusters, weighed one hundred and sixty-three grams. These results show that there were about 15 per cent more berries to the eluster upon the ent plants than upon the ordinary ones, and that these berries were abont 7 per cent heavier. The question of quality was only determined by tasting, but there was no doubt in the minds of the judges that the thinned clusters bore fruit of the finest flavor. Like all other fruit, eurrants sell somewhat upon their appearance, and there is no mistake that from the uniform size and ripeness of the fruit and 


\section{Thinning Small-fruits.}

the absence of dead tips on the stems, the elipped clusters were much the more attractive."

Experiments made at the Cornell Station* with raspberries and blackberries failed, however, to give such specific results: "To test the feasibility of thinning berries, rows of Cuthbert raspberry and Early Cluster blackberry were thinned by clipping off the tips of most of the clusters, and also by reducing the number of clusters, especially in the raspberry. The result was not encouraging, for the eye could detect no increase of size in the berries on thinned plants, and as the principal object was to increase the size and attractiveness of the fruit, it seems to have failed of its purpose. It should be said, however, that the season was favorable for berries, and the erop was very fine. In a very dry season, or with varieties much inclined to overbear, the result might be different. In general, however, the thinning can be managed well enough and much more cheaply by regulating the amount of bearing wood at the annual spring pruning."

The thinning of tree fruits is done in essentially the same way in which the fruits are picked; that is, the fruits are picked off by hand, and are then dropped onto the ground, where they may either be allowed to lie, or, if they are infested with insects or disease, may be raked up and burned. It is customary to thin the fruits as soon as the dangers of spring frosts and other early accidents are past,

${ }^{*}$ Fred W. Card, Ball. 57, Cornell Exp. Sta. (1893). 
but before they have beeome of sufficient size to be a tax upon the tree. Peaches are generally thinned when they are about the size of a small hickory nut (that is, abont the size of the end of one's thumb), and apples are thimed from that size nutil they are twice or sometimes even thrice as large. Various devices have been suggested for the thimning of fruit, but they are all impracticable, because they do not discriminate between good and poor fruit, beeause they do not leave the fruit well distributed over the branches, and beeause they are very likely to break off the spurs. Some of the implements figured in Chapter VIII. may be used in special cases. It really requires more diserimination and judgment to thin fruit properly than it does to pick it. In the thinning of peaches it is a good rule to allow none of the fruits to hang closer than four or six inches of earh other. This means that in years of very heary setting, fully two-thirds of all the fruits are to be picked off in June. In many parts of the country this thinning is systematically done, and it has in all such cases come to be regarded as an indispensable element in suecessful fruit-growing. No reliable estimates of the cost of thinning fruit can be given, because so much depends upon the form and pruning of the tree and the amount of fruit to be removed. The result is also greatly influeneed by the character of the workmen and the price paid for labor. Full grown peach trees may be thimned for 15 to 50 cents earh. Apple trees twenty-five and thirty years old have been well thinned for 30 to 80 cents each. 


\section{MAPS AND RECORDS.}

One of the most annoying parts of fruit-growing is keeping track of the various varieties which inevitably accumulate in plantations to which the owner gives much loving thought. The best means is a systematic plat, map or diagram of the plantation, in which every tree or every row of small-fruits is given a number. It is well to designate the rows in orchards by letters, and then to number each tree in the row, beginning with number one; or, some prefer to number all the trees in the plantation consecutively. It is an ideal plan for the grower to devote a large blank-book or record to each plantation, entering the plan of the area in the earlier pages, and then recording the yield of each tree or each row on consecutive pages which are devoted to the different years. Such a book would be to the orehard what the Babcock test is to the dairy,-a means of determining the unprofitable individuals. If such a record were kept, it would not be many years before the orchardist would be experimenting with a goodly number of his trees in order to determine how to make them as productive as the best ones are.

Of labels there are endless devices, but it must be remembered that no label can be expected to last in good condition more than six or eight years. For temporary or annual plants, where little horse work is done, the commercial garden stakes, $12 \times 1 \frac{1}{4} \mathrm{in}$., are excellent. These cost, when painted and made of 
soft, elear pine, $\$ 4$ to $\$ 5$ per thousand. For a more permanent stake label, one ent from clear pine, $2 \mathrm{ft}$. long, $3 \frac{1}{2}$ in. widle, $1 \frac{1}{2}$ in. thick, and sawed to a point, is one of the best. These are given two thin coats of white lead, eare being taken not to pile them upon their faces until thoroughly dry, to aroid a rough surface for the pencil. The reeord may be made by a large soft peneil, like a earpenter's pencil, or by a brush and blaek paint; but for all annual crops the peneil will be found more serviceable. At the end of the season, or when the reeord beeomes dim, a thin shaving is planed off the face of the label, it is repainted, and used again. The label is thiek enough to allow of many annnal dressings, while the lower portion is not redueed, and it therefore lasts for many years and is strong enough to resist the shocks of enltivator or whippletrees. For ornamental bushes, this large label is too conspienous, and for this purpose a pine label $1 \frac{1}{2} \mathrm{in}$. wide, $1 / 2$ in. thick, and 18 or $20 \mathrm{in}$. long is excellent. The lower half is soaked in a strong solution of sulphate of iron (eopperas), and, after drying, in lime water, to preserve it.

A great variety of labels has been reeommended for trees, but it is doubtful if we have yet found the ideal label, although some of those which are here described seem to satisfy most needs. Many people like zine labels (No. 11, Fig. 46), cut in narrow strips from a sheet of the metal. The record is made upon the zine with a soft lead peneil, and the label is then wound about a branch. Very often the record is 
indistinct upon the zinc label, but the chief fault is its inconspicuousness. It requires much searching to find a zinc label upon a large tree, and this objection holds with almost every practicable tree label which has been introduced, even with the three or four-inch pine labels which are common in the market. Patent zine and copper labels, which are eut from very thin metal, so that the record can be made by the impressions of a sharp point or style, have been tried at Cornell. "These pretty and so-called indestructible labels are furnished with an eyelet through which the wire passes. We were much pleased with these labels when we put them npon our orchard trees one fall; but the next spring we found that the metal had broken away from the eyelets, and nothing remained of them but a hole hung upon a wire."*

The Cornell label is the device shown at No. 3, in the illustration (Fig. 46). "We buy the pine 'package label,' which is used by nurserymen, and which is 6 in. long and $1 \frac{1}{4}$ in. wide. These labels cost, painted, $\$ 1.30$ per thousand. These are wired with stiff, heavy, galvanized wire, much like that used for pail bales, and not less than eighteen inches is used upon each label. Hooks are turned in the ends of the wires before the labels are taken to the field. A pail of pure white lead, well thinned with oil, is taken to the field with the labels. The record is made with a very soft pencil, the label is dipped into the paint, the wire is placed about a conspic-

*Bull. 61, Cornell Exp. Sta. 341. 


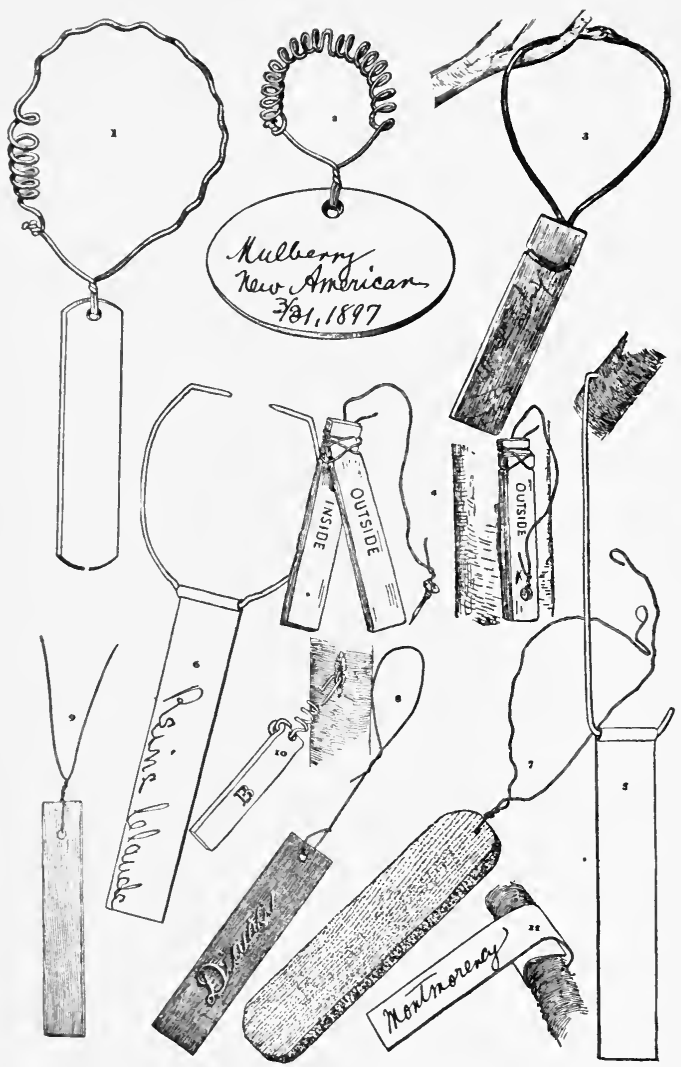

Fig. 46. Various types of tree labels. See explanation, on pages 308-311. 
nons limb, and the hooks are joined with a pair of pliers. The paint at first almost completely obscures the writing, but some of it drips off and the remainder dries in, so that the record becomes bright and the soft pencil marks are indelibly preserved, while the label remains white. If the paint is brushed on, the soft writing will be blurred. If in the future the wood becomes gray, the label can be brightened by immersing it in a pot of white lead, without removing it from the tree. The large loop of wire allows of the growth of the branch, and the label hangs so low that it ean be seen at a glance. The heavy, stiff wire insures the safety of the label against boys and workmen. It cannot be removed without a pair of pincers. The label is large enough to allow of a complete record of the name of the variety, the place of purchase, age, and other matters ; and it is readily found."*

The various labels which are shown in Fig. 46, are as follows: 1, 2, German labels, made of glazed earthenware, with the name colored blue and sunken. Strong copper wire, coiled, to allow of the growth of the limb, holds the label to the tree. 3, Cornell label, described above. 4, double wooden label, consisting of two common wooden labels fastened together. The name is written upon the outside of the double label, as in any other label, but it is also written on the inside to insure permanence. When the outside writing is worn off, the label is

*Bull 61, Cornell Exp. Sta., 341. 
opened and the inside is still bright. The label is fastened to the tree by a tack or small nail, as shown in the ent at the right. The label is seen opened in the cut at the left. 5,

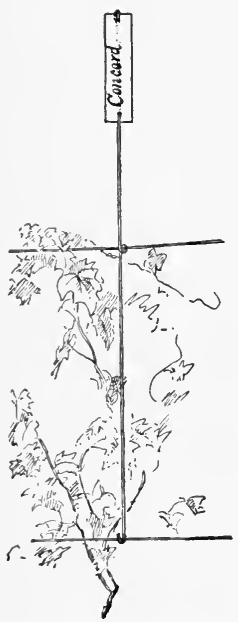

Fig. 47. Paddock's vineyard label. 6, zine labels, used at the New York State Experiment Station, Geneva. The wire is driven into the tree, and the name is written or printed on the zine with black paint. 7, common hand-made wooden tag, taken from an old tree in the test orehard of the late Charles Downing, Newburgh, N. Y. 8, thin copper label, with the name indented into the metal by the use of a hardpointed instrument. Some metal labels are apt to tear out at the hole when exposed to winds. 9, common painted pine label nsed by nurserymen, and costing (without the copper wire) about 35 cents per thousand, for the common size, which is $3 \frac{1}{2}$ inches long. 10 , Lodeman's label, used somewhat at Cornell, consisting of a tag of sheet lead securely fastened to a coiled brass wire. The wire is secured to the body of the tree by a staple or serew-eye, and it is expected that the wire will become imbedded in the trunk as the tree grows. No. 11, eommon zinc label or tally, described on page 308. Fig. 47 is Paddoek's vine- 
yard label (designed by W. Paddock, State Experiment Station, Geneva, N. Y.). The label is a strip of heavy zine secured to a stiff galvanized wire. This wire or shank is provided with a hook at the lower end and a half-hitch near its middle, so that it can be securely adjusted to the wires of the trellis, holding the label well above the foliage.

\section{INJURIES BY COLD AND RAIN.}

There are two distinct types of injuries to fruit plants by cold,-true winter-killing (or the injury of the tree or buds when perfectly dormant by the low temperature of winter time), and the killing of the growing or swelling parts by the "cold snaps" or frosts of late spring and early fall. Either subject is too large for full elaboration in the present volume, and therefore only some of the most obvious and usual aspects of the subjects are here considered.

Winter-killing of the wood.-There are three factors which chiefly appeal to the fruit-grower in the winter-killing of trees,-positive cold, very dry or very wet soil, and heaving of the land by frost. The subject of "dry freezing" has already been discussed to some extent in Chapter I. The heaving of the land is prevented by drainage, by proper methods of tillage, and by the judicious use of cover erops. The degree of cold may be somewhat modified, as we have already found, by exercising judgment in the selection of site and exposure, and by the careful employment of wind-breaks. Yet, winter- 
killing must always be one of the gravest risks which the fruit-grower assumes when he undertakes the business.

Winter-injury to the trees or plants themselves usually appears in the form of splits or long checks in the trunks, or in the ontright death of the ends of the branches, or even of the entire plant. For the splits lengthwise the trunk, the proper treatment is to pare off the dead and loosened bark to the "quiek" just as soon as the bark begins to spread, and to cover the surface of the wound (and the cleft) with Bordeaux mixture or paint.*

The proper treatment for frozen-back trees must be determined for eaeh partienlar case; but it should be borne in mind that the injured portion is no longer of any use to the plant, whilst it may be a positive detriment by aeeelerating the evaporation of moisture. The best treatment for plants seriously injured upon the extremities is to cut them baek very heavily. This severe heading-in-sometimes to the extent of three or four feet-removes the driest and weakest portions, and concentrates the energy of the tree into a eomparatively small area of top. Heavy pruning always tends towards the produetion of wood, and this wood production is probably never more needed than in winter-injured trees, for it tends to renew the vitality of the tree. The philosophy of this beeomes apparent upon a moment's reflection. The browned and injured wood can never re-

*The general subject of treating and repairing injured trees is fully discussed, with illustrations, in "The Pruning-Book." 
gain its former usefulness. New tissue must be developed as quickly as possible, in order to carry forward and to maintain the vegetative energies. This new tissue is laid on over the old, and the old thereby quickly becomes sealed in, so to speak, and removed from the agencies of decay. Every observant fruit-grower knows that if a tree which is severely winter-injured in limb and trunk were to bear even a partial crop of fruit in the coming season, it would very likely die outright. If, however, all its energies were directed to the development of new tissue, the injury would soon be overgrown. The injured wood, like the heartwood of the tree, is soon removed from active participation in the vital processes. It therefore follows that the danger resulting from the browning or blackening of the wood by winter-injury depends very much upon the subsequent treatment of the trees. Fig. 48 shows the body of a young plum tree (in longitudinal and cross-wise sections) which was frozen black in the severe winter of 1895-6. It was heavily pruned in the spring of 1896, and in the fall had made a ring of bright new wood, which was amply sufficient to maintain the tree in perfect health for a long life. This appearance is common in nursery stock the year following a very hard winter, but such trees may not be permanently injured.

There are instances in which this heavy headingback seems to do more harm than good. These are cases in which the entire tree is almost uniformly injured, and the plant seems to need the stimulus of 


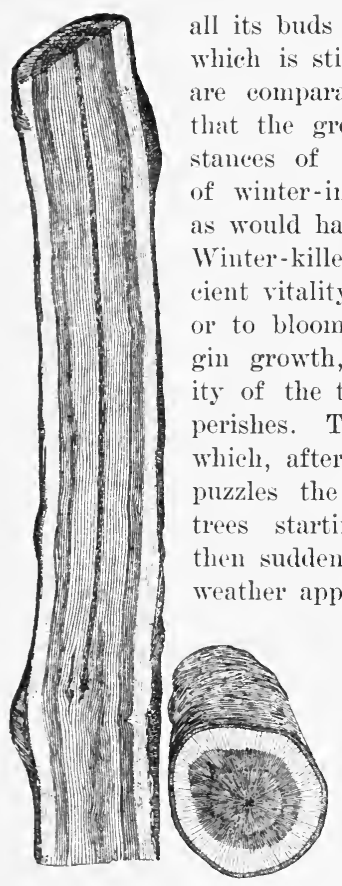

Fig. 48. Showing the new tissue

formed around winter-injured wood.

to bring out the feeble life till left to it; but these cases It is probable of reported in-

Winter-killing of the fruitbuds.-In severe winters, the entire fruit-spur (in the spurfruits, as apptes, pears, plums and apricots) may be killed outright, but the eommoner case is the death of the bud only. The bud may be entirely killed, in which case it soon turns brown throughout its entire diameter and the flower never opens: or only the pistil (the central organ, whieh ripens into the fruit) may be killed, in which ease the flower may 
open and appear to be perfectly normal to the uncritical observer. The latter case is common in peaches and apricots. Fig. 49 illustrates the point. The flower at the right was uninjured by the winter, and the pistil is seen, grown full length, at 1 . In the other flower, the pistil, at 2, is dead. We know that this pistil was killed before the bud began to swell, because it retains the small size which it must have had in the dormant bud. If it

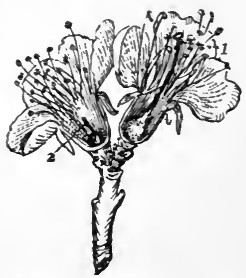
had been killed after the bud had Fig.49. Normal apricotflower swollen, it would have appeared as a much larger and a more (at 1), and one (at 2) injured by cold of winter.

or less crumpled or withered organ, as in $b$, Fig. 52 , page 320 .

A true fruit-bud is one in which the flower, or cluster of flowers, is present in miniature. (See "The - Pruning-Book"

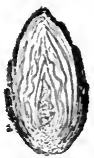

$a$

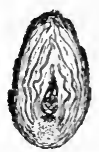

b

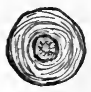

$c$

Fig. 50. Apricot buds. $a$, alive; $b$ and $c$, killed by winter. Enlarged. for full discussion of fruit-buds.) This flower occupies the very center of the bud, and is surrounded by dense layers of scales. A healthy bud is normally green in the central part in cross-section. When the bud has been killed by the winter, in the usual manner, this central portion of the 
flower becomes prominently discolored or almost blaek. Fig. 50 shows a fresh or live bud at $a$, and a killed bud at $b$ and $c$. When only the pistil is killed, untrained eyes may not deteet the injury. The general run of examinations made of buds by farmers, to determine if there is winter-injury, are of little conse-
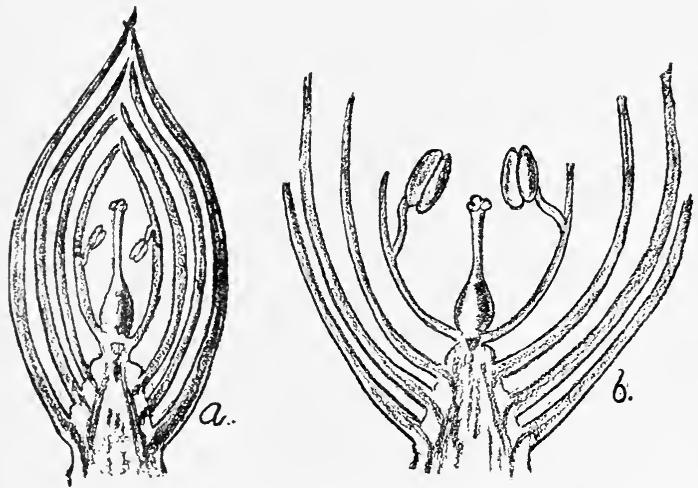

Fig. 51. Showing structure of peach buds.

quence. Except in very pronounced instances, the only reliable examination is one which is made under a dissecting microscope.

Halsted* makes some good observations in this direction: "Longitudinal sections through the buds show something of what has taken place in the pre-

* Rept. New Jersey Exp. Sta., 1890, 327; also Amer. Gard. xi. 266. 
maturely developed buds. At $a$, Fig. 51, is shown a section through a bud, as found in January of an ordinary winter. The bud seales overlap each other closely, and inclose all the more tender parts that go to make up the blossom. The pistil, that is to develop into the fruit, oceupies the center, and is a somewhat flask-shaped body, while next to it are the floral parts, to which the stamens are attached. The stamens are small and almost colorless. Turning now to $b$, which represents a section through a half-opened bud, it will be seen that there is very little change in the pistil. This portion is the last to be affected by the modifying cireumstances; but the scales are wide open at the top, the stamens have enlarged remarkably, and it is to their development that much of the opening out of the scales is due. It is only necessary, at this time, to eall attention to the fact that the stamens are organs for the production of pollen, and this flower-dust is only used to stimulate the receptive pistil into new life. And, while the growth of the pistil is mostly after fertilization, it is, however, true that during the time when it is receptive to the pollen it is most susceptible to cold and other conditions, and it is the portion of a peach bud that first manifests injury from frost or other exposure.

"The inference is natural that cold can get into an open bud much more easily than a closed one, but we need to look back of the visible differences to the vital conditions. Vegetable tissues in active eondition are less able to bear extremes of heat and cold than those in a quiescent state. A seed, for 
example, that is dormant will bear the conditions withont injury that would kill it if germination was taking place. The delicate structurc at the center of a flower not only needs to be kept, by the infolding bud scales, from being exposed to the elements, but, most of all, it requires that an inactive condition within itself shall prevail.
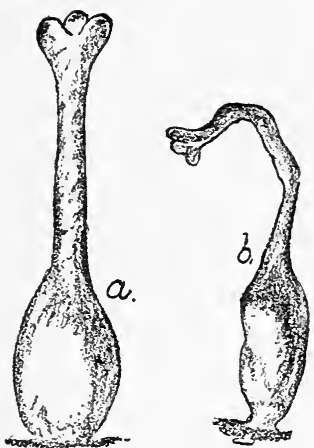

Fig. 52. Live and killed pistils. A well-prepared bud is like a seed, and becomes most susceptible to sudden changes only when it is unfolding or preparing to grow. It is not so much the opening of the bud scales as the growing condition within, resulting in the unfolding, that permits the dangerous results. "The pistil is the part first to show that the flower bud is blasted and worthless. The green, fresh appearance is replaced by brownness, and the former plump, upright organ becomes shriveled and drooping. In Fig. 52, at $a$, is shown a healthy pistil, as seen in a live bud. To the right, at $b$, is another pistil that has recently been killed, and was turning brown. The stamens are the next to change, in the same way, from the normal color to the brown of death. The other less vital organs of the blossom finally die, and after a short time become a dark and worthless substance. If the 
bud is not opened, it may require a longitudinal eut of the knife to determine the exact condition, but last winter an ordinary pinch of the swollen bud

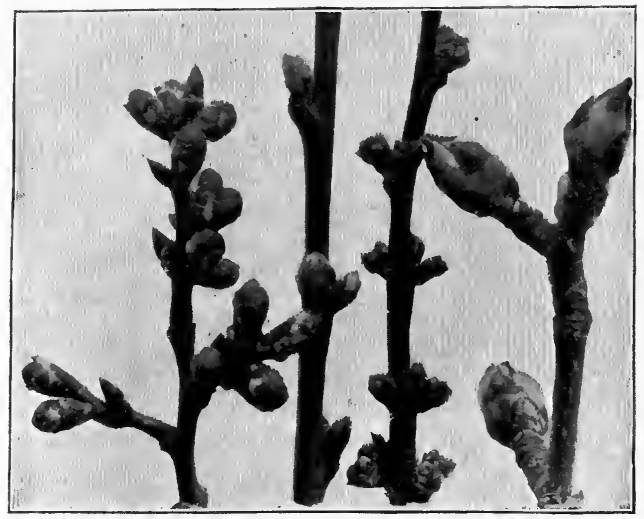

Fig. 53. Showing, respectively, swollen buds of apricot, peach, Japan plum, and pear, all of which were uninjured by $14^{\circ}$ of frost.

was enough to demonstrate that all was blasted and worthless within."

Injuries to the suelling buds.-A great amount of mischief is done by "cold snaps" after the buds have begun to swell, and yet the disaster is not so easily wrought, - at least not in the north, - as is commonly supposed. Even the buds of the tenderer fruits may endure very sharp freezes after they have begun to 
show rolor. In the spring of 1897 , some observations were made upon this point at Cornell. buds of apricots, peaches, plums and pears (as shown in Fig. 5.3) had swollen to three or four times their nolmal size. The pink color of the apricot buds was distinctly visible, and the tips of the anthers could be seen in the Japan plums by looking down stuarely upon the buds. In this condition, the buds endured with no injury the following temperatures, as taken by self-registering thermometers hung in the trees (very light snow on the ground and a wind blowing all night):

Lowest temperature.

April 20, Apricot, peach, Japan plum, pear .......... $18^{\circ}$

April 21, Apricot, peach, pear .............. 19

- Japan plum

It will be seen that these buds andured 14 degreess of frost withont injury. Cyon the coldest morning. the buds were stiff from freezing, and in some instances the backs and tips of some of the petals were permanently discolored. The buds swelled with the freezing, but returned to their previons size when thawed ont, but they looked as if withered for several days,-or until artive expansion began. It is very probable that buds cammot endure this degree of eold further south.

Injuries to flowers and groming purts.-When the flowers have fully expanded, a eomparatively light frost will destroy them. This is shown in the facet that a very slight elevation in a blackberry or straw- 
berry patch is often sufficient to avert injury. The pistils seem to suffer first. A strawbery nubbin is shown in Fig. 54. The top of the berry (or the bottom, as it hangs) is flattened and

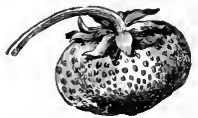

Fig. 54. A strawberry nubbin, due to frost. deformed. This is generally due to the freezing of the upper pistils in the flower, as it stood ereet. Nubbins are sometimes the result of imperfect pollination, but in such cases the deformity is more apt to be upon the sides than upon the top, for the top pistils are the ones which are very likely to be fertilized by insects.

A similar ease is reported upon blackberries at Cornell.* "The only serious accident which is known to injure the blackberry erop in this state is frost; and in most cases the injury is unavoidable, even though the grower has warning of its approach. In the six crops which we have grown in our patches here, only this year have we suf ered from frost, and even this year, when the cold wave was unusually late and severe, only the lowest places suffered seri-

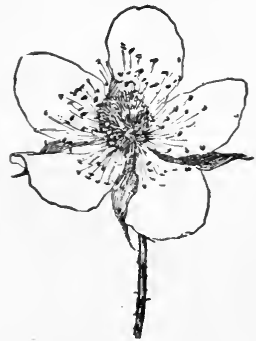

Fig. 55. Blackberry flower; full size. ously. Drawings of blackberry flowers were made upon the spot, two or three days after the frost, and

*Bull. 99, Cornell Exp. Sta. 1895. 
they are here reproduced, natural size. A normal, uninjured flower is shown in Fig. 5.5. Inside the five white petals or leaves are seen the numerous sprawling stamens or so-called male organs, each one bearing an enlargement or anther on the end, inside which the pollen is borne. In the center of the flower is the head or cluster of pistils or so-called fe-

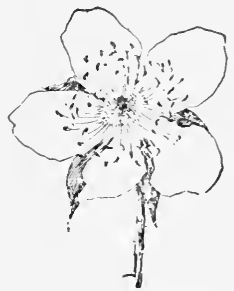

Fig. 56. Flower ruined by frost. male organs, each of which ripens into one of the little grains which go to make up the blackberry.

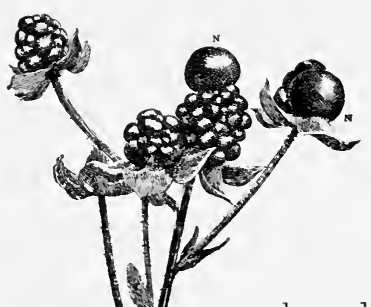
The frost killed these organs, so that the center of the flower bore only a small black column of dead pistils (see Fig. .56). Now and then, one or more of these pistils in the head

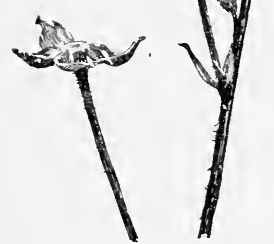

Fig. 57. Blackberry fruits ruined by frost. escaped, and developed into a fruit-grain, so that the berry became a nubbin. Fig. 57 shows the dead and aborted fruits at picking time. At the top of the picture are some fruits $\left(X, N_{\text {. }}\right)$ in which one or two grains or drupes are full grown, whilst the rest of the herry failed to develop." 
Upon the 8th of May, 1897, a temperature of $27^{\circ}$ ( $5^{\circ}$ degrees of frost) was recorded by self-registering thermometers hung in fruit trees at Cornell, but no injury resulted. At this time, all the petals had dropped from apricot flowers, but the calyx ring had not yet fallen from the young fruits ; peach flowers were in full bloom, but their fertilization had mostly taken place; Japan plum flowers were just dropping, and pear flowers were open, but not yet fully fertilized.

Young fruits of apples and pears may sometimes recover from a severe freeze and make perfect specimens.
Fig. [8. Frost injury ou young Kieffer pears.

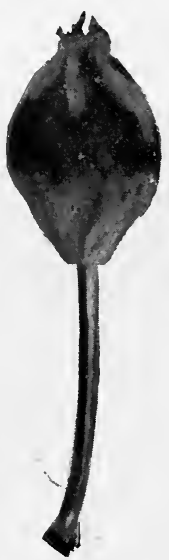

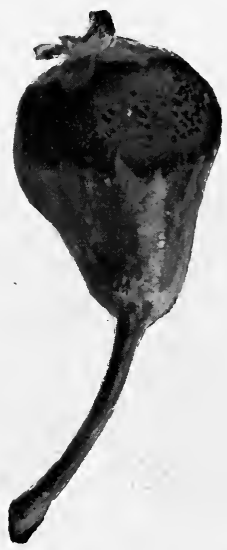
is even insisted by some careful observ-

ers that they sometimes recover even if frozen solid shortly after they are "set," the fruits failing to develop perfect seeds thereafter.* Fruits which are

* "The freeze of May, 1895; froze the fruit solid. The center of each pear turned black, and yet they persisted in growing. There were eighty barrels. I doubt if there was a seed or core in the whole lot. The quality was the best that I have ever seen."-Extract from letter from Benj. F. Hawes, Oakfield, N. Y. 
simply frost-bitten, - that is, injured by a deposit of white frost, - are very likely to persist, but to show blemishes or deformities even at maturity. A common effect of very late frosts is to leave a distinct russet zone mpon the fruit. This zone marks the position of the frost upon the young fruit. Apples and pears are usually still "rect when these frosts occur, and the dew, - which, when frozen, is frost,probably settles in a ring or belt near the top of the fruit or midway down it. The exalet position and conformation of this deposit of dew are, of comse, determined by the shape, position and exposure of the fruit. Figs. 58 and 59 show the frost zones on
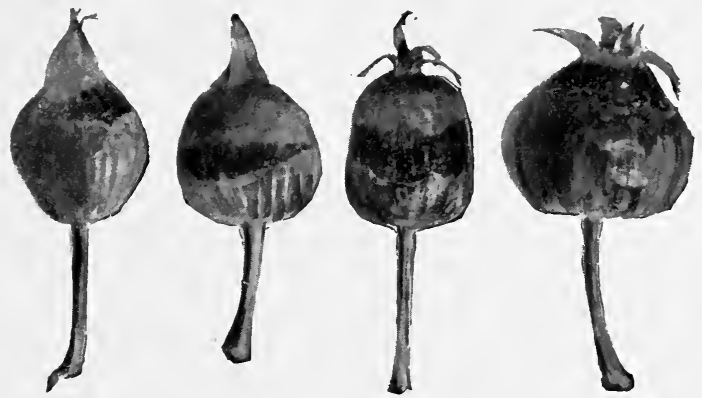

Fig. 59. Frost injuries on young apples.

roung pears and apples. This injured, corky tissue has the power of inereasing itself by the extension of the abnormal cells, so that the zone is likely to 
widen with the growth of the fruit. Mature fruits, with the rusty frost marks still conspicuous, are seen in Figs. 60 and 61. In some cases, the growth of

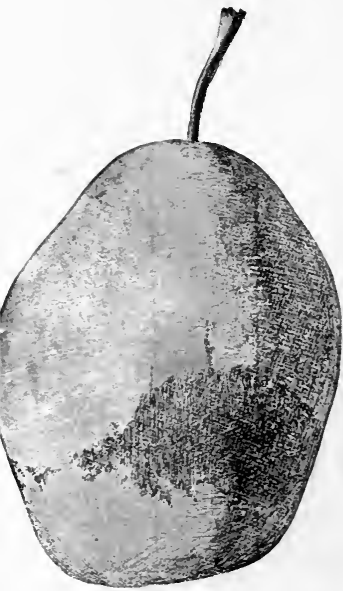

Fig. 60. Frost mark on a mature Flemish Beauty pear.

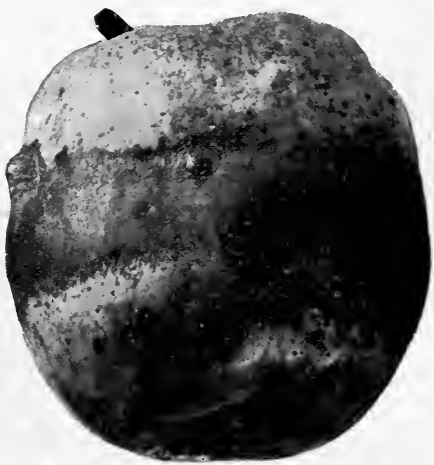

Fig. 61. Rusty frost zone around a mature apple.

tissue in the injured zone seems to be slow, resulting in a constriction of the fruit at that point.

Amongst the most serious results of very late frosts in the north are the injuries to vineyards. The cold of May 13, 1895, wrought great havoc in the Chautanqua vineyards of New York, and forced the problem of how to manage frozen vines 
upon the attention of growers. Fig. 62 shows the shoots of a grape vine as injured by the freeze. Acres of vineyards, which had made several inches of growth, were seemingly killed $\mathrm{ly}$ the disaster.

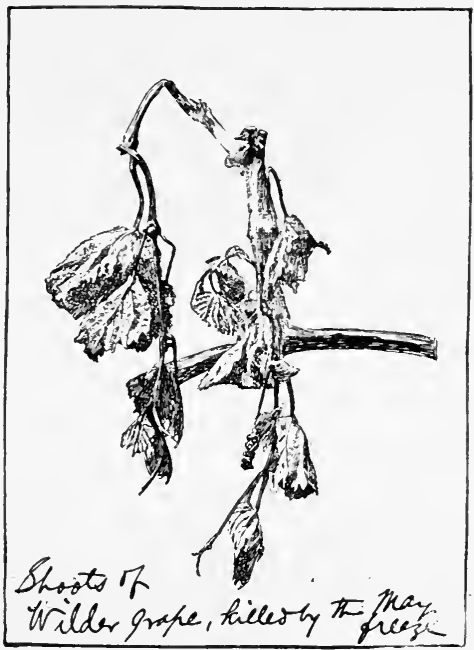

Fig. 62. Grape shoots ruined by the freeze of May, 1895.

The extent to which the rines had grown is shown by Fig. 63 (page 330). The spray upon the left shows the grapes of nornal size (that is, from uninjured shoots) as they looked in midsummer. The central spray shows grapes which were produced from the second crop of flowers, which appeared after the 
vines began to recuperate. The right-hand spray shows a cluster of flowers appearing upon a belated shoot. Of course, only the clusters of the largest size, as shown at the left, ripened into good fruit.

In proceeding to treat frozen vines, like those described, it must first of all be borne in mind that the injured parts are of no further use to the plants, and, as we have seen, they are very apt to weaken the plant by causing it to lose much of its moisture. The rational procedure, therefore, is to strip off all the frozen shoots soon after the disaster, so as to allow the energies of the plant to divert themselves to the production of new shoots. When the injured parts are soft and small, it is customary to remove them by pulling them off, rather than by cutting them off: In vineyards which are well pruned, the cost of stripping ought not to exceed one dollar an acre.

What is an injurious degree of cold * $^{*}$-To this oft-asked question there can be no specific answer, because so much depends upon the latitude, the time of year and the condition of the plants. Hammon $\dagger$ gives the following "table of temperatures at which the following plants are liable to receive injury from frosts, compiled from information received from horticulturists, orchardists and gardeners throughout the entire Pacific coast.

"The temperatures given are as nearly as possible those in contact with. the plant itself.

* A discussion of acclimatization, and other problems of climate and plants, , may be found in "The Survival of the Unlike."

† W. H. Hammon, "Frost, How and When to Prevent Injury Thereby," 1896. 


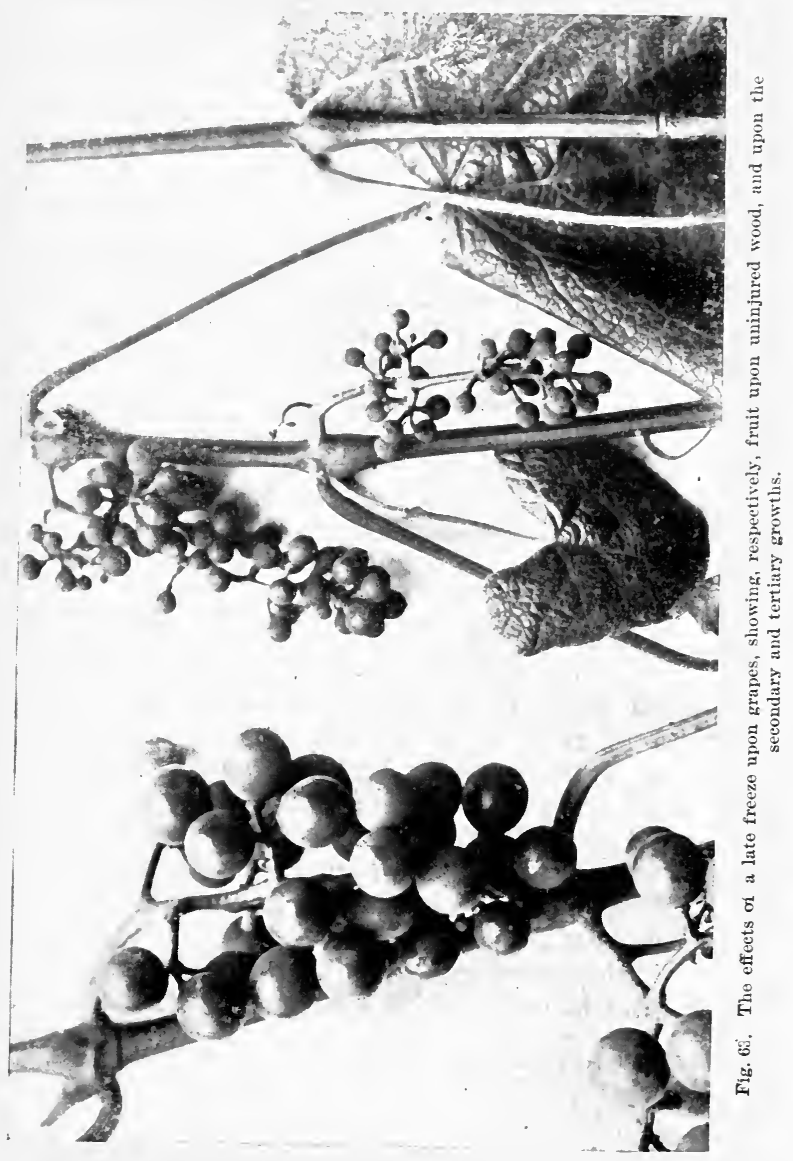


Plaxts or Fruits. In bud. In blos- In setting At other Almonds ................. $28^{\circ}$

Apples................ 27

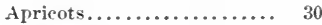

Asparagus............. 29

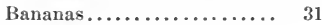

Barley.................. .

Beans ..................

Beets.................... ..

Cantaloupes ............ 32

Celery....................

Cueumbers.............. 31

Cymlings, or squas........ 31

Flowers*............... 31

Grapes ................ 31

Grape-fruit ............ 30

Lemons................. 30

Mandiarins and Tangerines.. 31

Oats.................. 31

Olives ................. 30

Onions ..................

Orangest ............... 30

Peaches ............... 29

Pears................. 28

Peas................. 29

Plums................. 30

Potatoes, Irish.......... 30

.6 sweet, and tomatoes 31

Prunes ................. 30

Shrubs, roses or trees .....26 to 30

Strawberries............ 28 som. fruit. times.

$\begin{array}{cccc}8^{\circ} & 30^{\circ} & 30^{\circ} & 28^{\circ} \\ 7 & 29 & 30 & 26 \\ 30 & 31 & 32 & 30 \\ 29 & 29 & 29 & 26 \\ 31 & 31 & 32 & 31 \\ \ldots & 29 & \ldots & \ldots \\ . & 31 & \ldots & 31 \\ 32 & \ldots & \ldots & 25 \\ 31 & 32 & \ldots & 30 \text { to } 31 \\ 31 & \ldots & \ldots & 28 \\ 31 & 31 & 31 & 32 \\ 31 & 31 & 31 & 30 \\ 30 & 31 & 31 & 30 \\ 30 & 31 & 31 & 28 \\ 31 & 31 & 31 & 28 \\ 31 & 31 & 31 & 28\end{array}$

Spinach................. .

Turnips ..................

Watermelons ..............

Wheat .................. .

Walnuts, English........ 30

$\begin{array}{lll}30 & 30 & 25\end{array}$

$\begin{array}{lll}31 & 31 & 29\end{array}$

$\begin{array}{lll}30 & 30 & 31\end{array}$

$31 \quad 31 \quad 31$

$\begin{array}{lll}31 & 31 & 29\end{array}$

28 to $32 \quad \ldots \quad 0$ to 26

$\begin{array}{lll}28 & 28 & 30\end{array}$

. 21

$\begin{array}{lll}\text {. } & \ldots & 26\end{array}$

. $\quad$.. $\quad 28$ to 31

$31 \quad 31$

$31 \quad 31$

28

* Depends on rariety.

$\dagger$ Injured at two degrees higher if eontinued 4 to 6 hours. 
We have alreatly seen (page 320.) that at Ithaca, New York, aprieots, peaches and other fruits were able to endure a temperature of $18^{\circ}$, even when the buds were well swollen. In respert to the variations in the effects of winter temperatmes, MeCluer* writes from the Illinois Experiment Station as follows:

"Here, we ordinarily think of $14^{\circ}$ or $15^{\circ}$ below zero as fatal to the peach rrop, and as we often have a lower temperature than that but few pearhes are planted. During the winter of 1894-5 the thermometer several times ranged below 20 , and onc. sank to 25 below zero, and yet only half the peach buds were killed, and the trees produced a good erop the season following. Last winter, with a minimum temperature of only $5^{\circ}$ below zero, fully one-third of the peach buds were killed. I do not know just what conditions made the buds more hardy one season than another; neither do I know why part of the buds on a tree should be more hardy than the rest. Even in the axil of the same leaf one bud may be killed and the other live.

"Other organic substances show the same differences. In a half-bushel basket of potatoes exposed to the cold in a cellar, I have often found frozen tubers scattered through the basket and the rest not frozen. In the blossom-buils of the cherry and plum one or more may often be found killed, while the rest have escaped.

* G. W. MeCluer, Garden and Forest, ix, 209 (Mlay 20, 1896) 
"When we first began to spray our peach trees to prevent the fruit from rotting, the Bordeaux mixture used was not properly prepared, and as a consequence a large part of the leaves on the sprayed trees fell off prematurely. The next spring it was found that there was a larger proportion of live buds on the trees from which the leaves had fallen than on the rest of the same variety. My explanation at the time was that the buds become less hardy in proportion as they are more developed. We know this is true in the spring. The question at once arises, at what stage in the development of a bud is it the most hardy, and how can we best control that development? This seems to me a promising field for careful study."

The effect of rain upon blossoms. - It is perfectly well known that the weather conditions in which plants are growing may profoundly affect the fecundity of the flowers. In the foreing of winter vegetables, for example, it is of the greatest importance to keep the house dry and warm when pollination is to be effected, and better results-both in the amount of pollen produced, and in the ease with which it is discharged from the anthers-are commonly obtained in bright sunshine. (See, also, page 227.) It is very probable that if the flowers of fruit plants were to be kept constantly wet, very little pollination would take place. It is probable, also, that dashing rains at blossoming time wash away much of the pollen, but it is doubtful if enough of it would be lost in such passing storms 
to serionsly redure the rop of fruit. The most disastrons storms are probably those milder ones of long duration, and which are accompanied by a low temperature. Not only may snch weather tend to prevent the discharge of pollen, but it prohibits the work of inserts.

It must be admitted that the above remarks are inferencess. We have almost no exact knowledgo as to the effect of rain storms upon the setting of fruit. A few small studies have so far been made in this country, and these are now quoted.

Bearh and Fairchild* report experiments in applying continuons sprays to pears and grapes. "On May 16 two Momnt Vermon pear trees, apparently of equal vigor, standing within one lmudred feet of each other, were selected. Into one was thrust the Vermorel nozzle, with its broad, fine spray. The tree was about twenty-five feet high, and the spray from the nozzle did not entirely cover it: in fact, the original design, soon abandoned, was to wot only one-half of the tree, and leave the other half dry. At the inanguration of the experiment, only a few blossoms had opened upon either tree, and, as no inserts had bern busy about the fruit trees, owing to the rold weather immediately preceding, no risk from previons pollination was run. The water was tmrned on at noon of Hay 16, and kept rmming (exrept from $10 \mathrm{~A}$. M. of the 21st, to $10 \mathrm{~A}$. M. of the 23d, dnring an almost constant rain-storm, pres-

\footnotetext{
*Eleventh Anu, Rep, X. Y. State Exp. Stit. for 189:, 6v7.
} 
eipitating .72 of an inch of water), until 3 P. M. of the 25th. The total length of time in which the tree was kept wet was two hundred and nineteen hours, or nine days and three hours.

"On May 17, after the tree had been under the spray twenty-four hours, an examination was made of the stigmas of many of the flowers, and they were found to be dusted with pollen, although no insects had been seen about the tree. Pollen was taken from fresh anthers on the 21st (the fifth day), and placed in weak sugar solution, to test its germinative power. It proved to be perfectly capable of germination. The flowers at this time presented a curious appearance. The anthers of the innermost, stamens were plump and of their normal pink color, while the outermost ones were swollen and decayed, and contained many disintegrated pollen grains, and a few that had evidently been induced to germinate by the excess of moisture. The power of the male elements to withstand long-continued moisture was apparently great, for at the close of the experiment, after the rain had ceased, many anthers opened and shed an abundance of pollen, while the anthers of flowers on adjacent trees had withered and fallen several days previonsly. After turning off the water, on the 25th, an examination with a hand lens was made of flowers on both the side nearest to and that farthest from the spray, with the following result:

"Of four hundred and three flowers counted on the side receiving the most water, one hundred and three were possessed of plump anthers and apparently 
normal stigmas. Of three humbed and three flowers upon the dryer side, only there were still fresh and rapable of fertilization. The effect of the water in retarding the development of the flowers was strikingly illustrated.

$$
* * * * * * * * * * * * * *
$$

"Althongh, as mentioned ahove, after the spray had been removed many flowers with perfect anthers and pistils remained capable, presmmably, of self-pollination, only one fruit, bearing three seeds, was borne by the tree. This was produced about midway between that half more heavily wet down and that more nearly dry. The unsprayed tree produced a fair crop of normal fruit.

"Two vines situated near each other were seleeted for an experiment. One was left mineated for a check, the other was sprayed for twelve nights and days. Since the Duchess rame into blossom later than was anticipated, the sprayed rine was under treatment a week before the eheck began to bloom. Cnavoidably the spray was diseontimned before either of the vines was out of blossom. It will, therefore, be seen that the twelve days' treatment did not cover the entire period that the vines were in bloom.

"The first apparent effect of the spray was to retard the opening of the grape hlossoms four days, as compared with the blossoming of the rherk vine. This effect was noticeable during the blossoming period, and the treated vine contimued in blossom at least fomr days longer than the rheck. Retarding the blossoming period, however, had no perceptible 
influence on the ripening of the fruit, for the fruit of both vines ripened at the same time. * * *

"A microscopic examination, made after the spray had been running eleven days, failed to disclose any perceptible injury to the pollen. The pollen germs were not disintegrated, nor had they germinated, and no difference could be detected between them and pollen grains from the check vine. By its peculiar structure the grape blossom is well adapted to withstand protracted rains without injury to the sexual organs. As shown by one of the writers in a recent paper (see page 230), many grapes pollenize their own stigmas before the blossoms open enough to allow the entrance of outside pollen, and the Duchess belongs to this class. Although self-pollination is thus insured, efficient fertilization does not always follow, and consequently in some varieties it does not result in the production of fruit. Such grapes are able to set fruit only when supplied with outside pollen. It is, therefore, probable that with grapes of this class, e. g., Salem and Brighton, the effect of constant spraying throughout the blossoming period would give more marked results than with the variety noted in this experiment.

"The most marked and permanent influence of the spray was seen in the character of the fruit. The clusters from the treated vine had very many abortive berries, either with no seeds at all or with only mere rudiments of seeds. A few clusters were. nearly or quite perfect. These may have blossomed after the spray had been discontinued. All other 
clusters had many abortive fruits, and showed every gradation of loss up to 80 or 90 per cent. No cluster was seen in whieh all the berries were abortive. With the eheek vine perfect elusters were numerous, and abortive berries were comparatively few. The whole loss of fruit on the sprayed vine cannot be computed by comparing the amount of perfect with abortive fruit, because some blossoms must have failed to form even abortive fruit, and some of the abortive fruits dropped before the grapes were gathered. It should be borne in mind, therefore, that the total loss of fruit from the spraying is not represented in the following figures. $A$ eomparison of the fruit of the two vines shows the following results:

"1. Counting all berries, whether perfect or abortive, the average weight of a berry from the sprayed vine was $8 . \bar{j}$ grains, and the average weight of a berry from the eheek vine was 17.5 grains, showing a difference of 106 per eent.

"2. The amount of abortive berries was compared with the perfeet berries of each vine, and 60 per cent of the fruit from the sprayed vine was abortive, while but 21 per eent of the fruit from the eheck vine was abortive."

Halsted* has also made observations upon the influence of weather upon pollination, and finds that continued wet weather at blossoming time seems, in most eases, to lessen the setting of the fruit.

*Special Bull. C, X. J. Exp. Sta. (1889), and Rept. for 1889, D. 230, and Rept. for 1890 , p. 330. 
Card* has made experiments in the spraying (to imitate rain) of raspberries: "It is generally supposed that rainy and cloudy weather at blossoming time is injurious to the fruit crop, and the question occurs whether frequent spraying with water at this period would produce any noticeable effect. On June 15, 1892, spraying was begun on Caroline, Cuthbert and Turner raspberries. At that time the Caroline was well in bloom, while the others were scarcely beginning to bloom. The spraying was continued until July first, two to four times each day when the weather was bright and pleasant, but omitted when there were rains to take its place. Showers were frequent during the period, but were well interspersed with bright weather and sunshine. "The results were entirely negative, showing no effect whatever from the spraying. The fruits on this portion of the row were just as perfect and abundant, and the plants appeared to suffer no more from fungous diseases than those not sprayed. It is to be noted, however, that the conditions were not the same as those present in continuous eloudy weather, for during much of this time the weather was bright, and insects were numerous, and continued working among the blossoms regardless of their being wet, so that opportunities for pollination were good. The test is of interest as showing that there need be no fear of interfering with pollination by spraying for insects or diseases, even if necessary to do it at blossoming time. Of course, it should not be done

* Fred W. Card, Bull. 57, Cornell Exp. Sta. 
at that time, ordinarily, on account of our friends, the bees."

Coote reports that peaches under glass set less fruit when sprayed in full bloom with either warm or cold water than they did when pollinated by means of a brush.*

\section{RENOVATING OLD ORCHARDS.}

It is impossible to give any specific method of procedure when it is desired to renovate an old and profitless orchard. It is first necessary to discover the causes of its unprofitableness - to diagnose the difficulty - and then to go straight at the root of the eril. It must be remembered, too, that an old, neglected orchard camnot be expected to arrive at the profitable condition which trees enjoy which have received proper care from the beginning, no matter how thorough the means of recuperating it may be. At the best, one can only make an apology for long years of neglect and mistakes. It is probable, too, that the trees may sometimes become so fixed in habit that no amount of good treatment can make them bear satisfactorily. If the grower once arrives at a clear conception of the agencies which make for productiveness, he will readily perceive what the trouble with his orchard may be.

In general, it may be said that the first thing to do to revive an old orchard is to till the land.

\footnotetext{
* George Coote, Bull. 34, Oregon Exp. Sta. (1895). This bulletin also contains observations on the pollen production of varieties of fruits.
} 
This may demand a heavy trimming up of the trees in order to allow a team to work in it; and in many of the forest-like old orchards it may be economy to cut out a third or half the trees at the start. Perhaps the roots are so high that the land cannot be plowed. In such case, the land may often be broken up in the spring, before the earth becomes hard, by means of spading-harrows, disc harrows, spring-tooth harrows, and similar vigorous tools. Or corn and other grain may be dropped. freely in holes made with a crow-bar, and the hogs then turned in. Let them root for it!

The earth-mulch once secured to save the moisture, it may next be necessary to apply plant-food, either in the form of stable manures, green crops or concentrated fertilizers, or in all these forms together.

It is probable that the trees will need heavy pruning. But this pruning is for the purpose of correcting the results of years of neglect, not for the purpose, directly, of making the trees bear. In fact, the effect of heavy pruning is apt to be in the very opposite direction from fruit-bearing; but it must be done in most old orchards to bring the trees back into manageable shape, to produce new and fresh wood for fruit-bearing, and to thin the top sufficiently to allow the fruit to develop to something like perfection of size and quality. Weak trees may sometimes be re-invigorated by this heavy pruning alone. Severe heading-in of old peach trees often accomplishes this. When the new wood is once 
formed and the tree has re-established its equilibrium, fruit-bearing may be expected to begin, if other conditions are right.

It will next be necessary to begin hunting for borers and other squatters and campers. The trees will very likely need to be thoroughly sprayed to dislodge the army of hangers-on which has held undisputed possession of the territory for a decade or two.

If the trees are of the wrong varieties and are still vigorous, it will probably pay to top-graft them, as already explained (page 298), if they are apples, pears, oranges, or cherries. Old and poor peach, apricot, plum and quince trees had better be pulled out.

Why are orchards barren?-It may be suggestive if the matter of renovating old orchards be put in the form of this question and categorical answers be given. It will help the grower to diagnose the trouble, and it will impress him with the fact that he is the man to solve his own difficulties. The commonest reason why old orchards are barren is because they are in sod,-that is, because they are untilled and unfed. There are men enough in the country-although they have been greatly in the minority-who have boldly taught that sodded orchards are wrongly managed orchards. They have been combatted by citations of orchards which are in sod but are still productive. They have replied that in some cases, for a combination of reasons, orchards may do well in continuous sod, but they 
have still fallen back upon the fundamental principles of land management, and have said that the system is nevertheless wrong. Time is rapidly demonstrating the accuracy of their prophecies. It is a case in which a handful of philosophy is worth more than a forkful of facts.

If one asks why orehards are barren, let him fill out the following synopsis by way of review of some of the principles which are enunciated in this book :

The nature of the problem: each case must be investigated by itself; teaching must be along the line of general or fundamental principles, not statements of rules. The six general factors which determine productiveness are:

1. The Tillage Factor.-Soil texture. Fertility as influenced by $(a)$ fineness, $(b)$ eonditions of root-hold, $(c)$ life processes, $(d)$ air-holding eapacity, $(e)$ water-holding eapacity.

Sod in orehards Cover erops.

2. The Fertility Factor. - Our conceptions of the uses of nitrogen, potash, phosphoric acid, ete., in fruit-production.

3. The Pruning Factor. - The relation of pruning to woodgrowth and fruit-growth.

4. The Variety Factor.-(a) Unproductive varieties, (b) impotent varieties.

5. The Propagation Factor.-The individuality of the tree, and its power to perpetuate its eharacteristies.

6. The Parasite Factor.-(a) Fungi, $(b)$ insects. Spraying (Chapter VII.). 


\section{CHAPTER VII.}

DISEASES, INSECTS AND SPRAYING.

In 1886, the present author wrote as follows: "A remedy proposed of late is to syringe the trees with a mixture of Paris green and water, very early in the season, while the young apples stand erect. The poison lodges in the 'blossom end' and destroys the first brood of worms. Later, when the apples turn downward, the poison is washed out by the rains. This remedy was proposed, and its entire success demonstrated, by Professor A. J. Cook, of the Michigan Agricultural College. A tablespoonful of poison to a gallon of water is sufficient."* This represented very nearly the sum of knowledge respecting the spraying of orchards at that time. Just ten years later, the writer had a part in putting before the public a manual on spraying, $\dagger$ which made a closely printed book of some four hundred pages. These contrasts will serve to show how rapid has been the evolution of the spraying of plants to combat insects and diseases. This sudden development of the spraying of orchards has tended

* "Field Notes on Apple Culture," 88.

†Lodeman, "The Spraying of Plants." This work should be consulted when full information is desired upon the history and practice of spraying. 
to magnify its importance out of all proportion to other accustomed operations of fruit-growing. The practice has been hailed as a positive means of making orchards fruitful. As a matter of fact, however, it makes orchards fruitful only when the eause of unfruitfulness is incursions of insects and fungi. It will not correct the faults of poor tillage, nor of insufficient plant-food, nor of unprofitable varieties, nor of neglect in pruning. In other words, it is only one of the various elements which enter into successful fruit-growing. Wholly aside from its direct and immediate importance, spraying has had an emphatic secondary influence in waking up the horticulturist. Any movement which sets a man to thinking very strongly along one line is likely to awaken his interest in eognate subjects. So it happens that spraying has been one of the means of rapidly diffusing a better knowledge of horticultural operations. Some of the directions in which this secondary influence of spraying is bound to enlarge the horticultural horizon may be stated as follows:

1. The necessity of spraying ealls the attention of the grower to the reasons for the recent incursions of pests. Spraying was unknown in his boyhood days. Why is it so imperative now? This opens a volume of suggestion, and will lead the questioner to consider the fact that insects and fungi are constantly changing their habits from one plant to another, as the native plants are destroyed and as the area of cultivated ones is increased, and 
that the continuing commerce with all parts of the world constantly exposes us to new dangers. Pests which have latterly broken out with fury have been breeding in unobserved numbers in the neglected plantations for many years. The ideals of the fruitgrower are also higher now than they were a few years ago. Competition has increased, and the smallest blemish on a fruit is enough to throw it out of a first-class article, whilst a few years since it might have passed without comment.

2. The necessity of spraying is bound to force new ideals upon the grower. Those persons who grow in a large way for the general and more or less staple markets will find themselves casting about for those varieties which are least susceptible to disease and insect injury and which, therefore, need the smallest amount of attention in the way of sprays.

3. On the other hand, the protection which spraying affords will tend to bring in many of those good old varieties which, like the Virgalieu pear, have almost disappeared from eultivation because of disease. Those persons who are growing special kinds of fruit for particular or personal markets will select the varieties of ideal qualities almost independently of the liability to insect or fungous attacks, because they are now assured that these attacks can be overeome. On the one hand, therefore, spraying will force the selection of varieties which do not demand this extra care and treatment; and, upon the other hand, it will afford the grower of fruits for dessert 
and home use the protection which he has heretofore not enjoyed.

4. Spraying is bound to force a closer study of the companionships and inter-relations of crops, fungi and insects. It will teach the farmer to observe that certain pests follow the round of certain crops, and that when he breaks such a rotation he also lessens the liability of attack. It will also force him to the use of shorter rotations, for it is a very nimble insect or fungus which can keep pace with a lively and resourceful farmer. He will come to learn that the best treatment of the anthracnose on raspberries may be a short rotation rather than spraying. In fact, the best treatment may be a combination of both; but he will find that if he reduces the number of crops to two or at most to three, and then has plantations coming on in other land, he will suffer comparatively little. The same suggestion is extremely applicable to the cultivation of strawberries.

5. Spraying will take its place along with tillage, fertilizing, pruning, and the other cardinal operations of the fruit plantation.

6. Spraying is bound to force better care, in order that the crop may repay the extra cost of the treatment. The advent of the potato-bug has no doubt exercised a very pronounced influence in improving the cultivation of the potato, and it is probably not too much to hope that the apple-scab is bound to revolutionize apple-growing in the northeastern states. 
7. The necessity of spraying must ereate a greater watehfulness on the part of the fruit-grower for new pests, for these pests are all the time appearing from foreign eountries, from adjacent states or geographieal regions, or from the wild.

8. Inasmueh as every new subject of inquiry awakens new thoughts and expands one's sympathies, so it becomes a means of enlarging and edueating the man. A concentrated invasion of the army-worm is one of the very best means of waking up any farming community and of setting every man, woman and ehild to asking questions of every passer-by, every agrieultural editor and teacher, and experiment station. The good effects of such an invasion are likely to last for a number of years. It is surprising, as one thinks of it, how easily people are scared by a bug! A strange insect, which perhaps does not weigh a grain, will set a whole eommunity of ablebodied men agog, and may cause as mueh downright fear and discussion as a political revolution.

There are three general types of diffieulties which are germane to the discussion in this ehapter. A classification of these troubles might be made as follows :

1. Attacks by inseets.

(a) The injuries of those insects which eat or ehew the parts of the plant, and which, therefore, are killed by the applieation of poisons like Paris green. Sueh inseets are the whole tribe of eaterpillars, worms and beetles. 
(b) Attacks of insects which suck their food, and which are, therefore, destroyed by caustic applications which injure the bodies of the pests. All the tribes of plant-lice and scale insects belong here, and for these the kerosene emulsion, resin washes, and the like, are the specifies.

2. Parasitic fungous diseases, such as the applescab, black-rot and mildew of the grape, leaf-blight of the plum and pear, black-knot, and the like. These diseases are characterized by definite spots, discolorations or excrescences, which are more or less scattered over the surface of the leaf, fruit or branch. As a rule, the leaves and fruits which are attacked have a tendency to drop from the tree. The general treatment for these diseases is to spray with some fungicidal mixture, like the Bordeaux mixture or the ammoniacal carbonate of copper. The treatment is useful in proportion as it is applied early and thoroughly. After the fungus once gets into the tissues of the host-plant, it is difficult, if not impossible, to kill it. If, however, the fungicide is upon the plant before the fungus is, the parasite may not be able to obtain a foothold. Even after it does obtain a foothold, it is probable, however, that the spray will check its spread by preventing the development of its external parts.

3. The physiological and bacterial diseases, or those which are termed constitutional troubles. In these cases, there are rarely any definite spots, as in the attacks of parasitic fungi, but the entire 
leaf, or even the entire plant, or a large part of it, shows a general weakening and disease, as if there were some cutting off of the aceustomed souree of nourishment. Sueh diseases are very likely to be seen in a general yellowing and death of the leaf, in the dying of the leaf along the main veins and around the edges, showing that the difficulty is one which affeets the entire leaf, and not any partieular part of it. In general, there is a tendency for the foliage in plants so attaeked to wither up and hang on the tree for a time. The peach rellows and pear blight are diseases of this kind. There are no specifie treatments for troubles of this sort. They must be approaehed by what physicians eall prophylaxis, - that is, by methods of sanitation and prevention. The diseased plants or parts are ent away and burned. All those eonditions which seem to favor the development of the disease are removed. Varieties which are partieularly susceptible are discarded. Careful management in matters of this sort is often mueh more important than any attempt at speeific treatment.

Before taking up a diseussion of spraying, it may be said that the best treatment for borers and similar pests is to watch the plants earefully, and to dig the inseets out at least twiee every year. In grounds which are kept in elean tillage, sueh insects are rarely as troublesome as they are in negleeted areas. This is both beeause the insects find places of lodgment in negleeted orehards, and because the fruit-grower is so seldom present that 
he does not discover them in season. The various protective washes which are advised for keeping borers out of trees are of very doubtful efficiency.

The roots of fruit trees and brambles are very likely to be affected with large tuberlike swellings or galls, which have been the subject of a good deal of uneasiness in various parts of the country. One of these is shown in Fig. 64. So far as known, these galls are not contagious, and the amount of harm which they do has probably been overstated. The rootknot of the southern states and of greenhouses is a wholly different trouble, and is the work of a nematode worm. There is also a root swelling or gall on raspberries, due to the work of an insect. The nematode galls are commonly smaller and softer swellings, and occur on the younger or smaller roots, and appear not to occur in

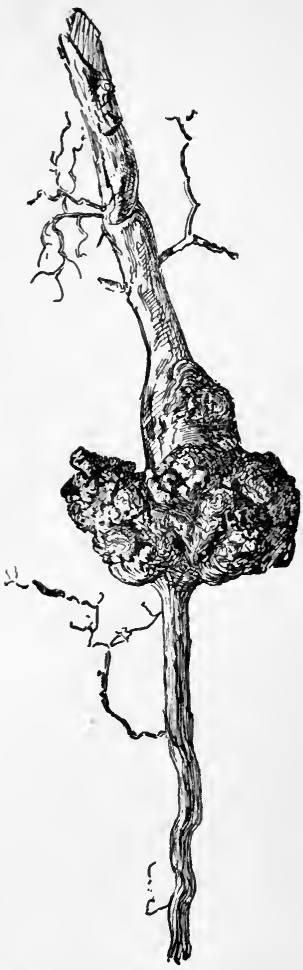

Fig. 64. Root gall on raspberry. (From Bull. 100, Cornell Exp. Sta.) 
the open in regions where the ground frcezes deep. This subject of the root-galls has been fully gone over by various writers, and a summary of the subject is presented in Bulletin 117 of the Cornell Experiment Station (although this subject is by no means well understood), from which the following epitome is elipped: "The conclusion of the w.role matter, then, as we now

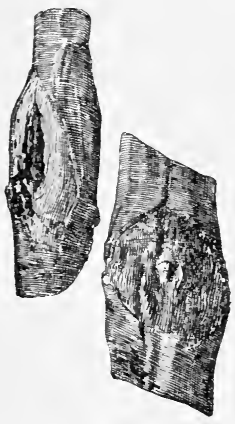

Fig. 65. Injuries by hail. stones. understand it, is that these rootgalls are not the work of a parasite, but are a mal-formation following some injury of the root, or some uncongenial condition in soil or treatment. The galls may seriously interfere with the nutrition of the plant, in many cases causing it to become weak and sickly. It is probable that the trouble is not communicable, and that cutting off the gall averts further trouble from that source. As a precantionary measure, however, we much prefer to plant only trees with perfectly clean and normal roots."

The injuries caused by hail are very often confounded with those wrought by borers and other pests, and it is the delight of many persons to endeavor to puzzle the experimenters and teachers with specimens of such work. Plum limbs injured by hail-stones are shown natural size in Fig. 65 . 
When it is desired to secure extra fine fruit, it is a good plan to tie up the fruits in paper bags. This keeps away the insects and fungi (although the whiteness of the bags is likely to attract thieves at night), and the fruit is apt to ripen earlier, and to be of higher quality because of the warmth which the bag gives. If it is desired to bring ont the blossoms of a tree very early in the spring, it may be done by tying grocers' bags upon the spurs when the buds first begin to swell. The bagging of grapes is a frequent practice when exhibition or test specimens are desired. It is customary to pin the bags upon the clusters when the grapes are a third to a half grown. Bags made of mosquito netting are very useful later in the season, when it is desired to secure the full color of highly-colored fruit.

\section{SPECIFIC REMARKS UPON SPRAYING.*}

1. Spraying is only one of the requisites to success in fruit-raising.-Spraying has come into use so quickly, and so much of the attention of teachers and experiments has been given to it, that many peopie have come to look upon it as the means of salvation of our orchards. If spraying is to have the effect of obseuring or depreciating the importance of good cultivation and fertilizing, then it might better never have come into being. Trees must grow before they ean bear, and this growth depends upon food and proper conditions of soil,

* Largely adapted from Bull. 101, Cornell Exp. Sta. 
more than it does upon the accident of immunity from insects and fungi. There are four fundamental operations upon which all permanent success in most kinds of orchard culture depend, and their importance lies in something like the following order, - tillage, fertilizing, pruning, spraying. Spraying is the last to be understood, but this fact should not obscure the importance of the other three.

2. Spraying is an insurance.-There are always elements of risk in the growing of fruit. The chief of these is frost, a difficulty which can never be completely under our control. The second great element of risk is the injury wrought by insects and fungi, and the greater part of this injury ean be averted by the sprays. Now, it is impossible to foretell by any considerable length of time, if any or all of the diffieulties which are liable to harass the fruit-raiser will actually appear. One does not know if his buildings will burn, yet he insures them. We know that in four years out of five, some serions injury of insects or fungi may be confidently expected, and it is the part of wisdom to insure against it. The year 1894 was a season of remarkable invasion of apple-scab fungus in New York, and those persons who sprayed their orchards thoronghly had phenomenal results. These experiences, aided by many publications upon the subject, so advertised the value of the sprays that much more spraying was done in the state the next year than ever before. But it so happened, probably because of the dry spring, that eomparatively few invasions of enemies 
occurred the next year; and the sprays generally gave small results. There arose, therefore, a considerable indifference or even opposition to spraying, which may be regretted when years of serious invasion arise. It is a common fault with farmers that they draw their conclusions from the behavior or experiences of each recurring season, and do not consider the aggregate results of a series of years. Every operation should rest upon some fundamental reason or philosophy, rather than upon any single half-understood experience.

3. Spraying is of some value every year, upon apples, pears, plums, quinces, grapes, and various other fruits.-Even in years of great immunity, nearly all sprayed orchards carry a better foliage than those which are untreated. So, wholly aside from the idea of insuring against risk, it is advisable to spray for those insects which are more or less abundant every year. Some insects and diseases appear late in the season, so that in any year the spray may be needed at some epoch in the season. It is, perhaps, useless to urge people to spray their orchards. Those persons who will not spare the trees this much of their attention will not be likely to do much in the way of tilling and fertilizing. One must grasp the entive body of principles of orchard management before he can hope for permanent rewards.

4. Spray thoroughly, or not at all.-Fully half the spraying which is commonly done is a waste of time and material. Squirting a few quarts of water at a tree as one hurries past it, is not spray- 
ing. A tree is thoronghly and honestly sprayed when it is wet all over, on all the branches and on both sides of all the leaves. An insect or a fungus is not killed until the poison is placed where the pest is. Bugs do not search for the poison, in order that they may accommodate the orehardist by committing suicide. The one spot which is not spraced may be the very place where a bud-moth is getting

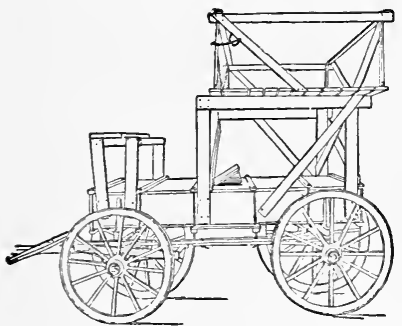

Fig 66. Rack for spraying rig. his dinner. On the other hand, there are many fruit-growers who spray with the greatest thoroughness and accuracy, and they are the ones who, in the long run, will get the frnit.

5. Prepare for next year's work during the vinter.-Secure nozzles and pumps, and fix up the wagons. It is especially important that the wagons be handy. In very low orchards, a low truck may be needed, and in some cases a stone-boat is best; but most orchards will need some kind of a high rig, to enable the operator to reach the tops of the trees. Fig. 66 is a rig nsed by T. G. Yeomans \& Sons, Walworth, N. Y. The tank holds 300 gallons. The pump is placed on the front of the rig (in the seat-rack), and one man drives and pumps. The horses are stopped at every tree. Two leads of hose are used, and two men stand on the rear platform 
and direct the nozzle. These men have ample space, and the railing gives them security. A boy has been employed until recently to agitate the liquid with a large hoe. These three men and the boy cost $\$ 5.50$ per day, and they can spray thoroughly about five acres of full-grown apple trees in a day. An automatic agitator has now been employed in place of the boy, with good results. Another good rig is that shown in Fig. 67, used by A. H. Dutton, Youngstown, N. Y. Many other efficient spraying outfits are in use, but these two will serve to illustrate the kind of work which is needed to be done.

The greater number of fruit-growers use an ordinary

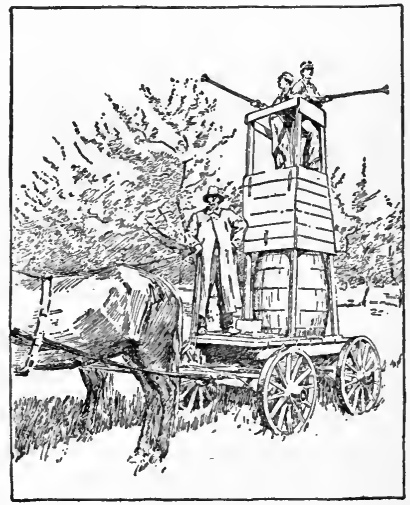

Fig. 67. Rig for spraying. wagon, with box or

rack, and a single 50-gallon barrel; but if one has much 'spraying to do, it is generally economy to use a larger tank, especially if water has to be hauled some distance; and more thorough work can be done in old orchards if the operator is elevated above the barrel. The use of long pieces 
of half-inch gas-pipe with the nozzle attached to the end, is advisable when one is working in the tops of the trees, but they are apt to be a nui-

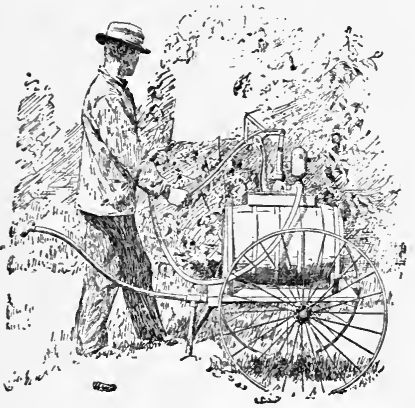

Fig. 68. Handy outfit for bushes and small sance if one works from the ground. They are awkward if more than ten feet long. We generally prefer to use a bamboo fishingpole, and secure the hose to it near its upper end, letting the lower part of the pole remain free. Most operators have insufficient hose.

For work in old orchards, the run should be at least fifteen feet long. For yards and ornamental plants, a cart-like rig, like that shown in Fig. 68, is handy and efficient, and others are shown in Fig. 72. A home-made rig for spraying strawberries and potatoes is seen in Fig. 69. It is simply a barrel pump mounted on wheels, with three Vermorcl nozzles rigged on the tail-board, so as to eover as many rows of plants.

6. The style of pump and nozzle to be used depends almost wholly upon the particular kind of work to be done.*-The reader will now see that the advice

* The reader shonld consult Lodeman's "Spraying of Plants" for more specific advice on this subject. 
as to machinery must depend upon the specific purpose for which the appliances are to be used. Apparatus which was devised a few years ago for the distribution of Paris green may be of no value for the application of such a thick compound as the Bordeaux mixture. Whatever the outfit selected, the pump should be strong and powerful, with hard brass working parts, and capable of throwing much liquid with great force. In respect to nozzles, it may be said that there is no one kind which is best for all purposes. It is desirable that the liquid should reach the plant in the form of a very fine mist; but it is just as important that the nozzle should have the power of throwing the liquid to the desired point: In other words, there are two elements to be considered,- the nozzle must have earrying power and delivering power. A fine mist at the orifice of the nozzle is of no use when the nozzle is thirty feet short of the bug. With many of the modern devices, the man who holds the hose in spraying rigs may stand eight or nine feet above the ground and he may use a pole

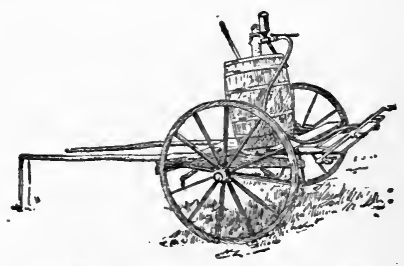

Fig. 69. Outfit for spraying strawberries and potatoes. twelve to fifteen feet in length, which will elevate his nozzle something like twenty-five feet from the ground; but many of our apple trees are fifty and sixty feet high. It will 
therefore be seen that the liquid must carry itself twenty-five to thirty feet beyond the nozzle. For such purposes, a nozzle which distributes the liquid in a spray directly from its orifice is of small use. A nozzle must be had which throws a more or less solid stream, and the stream should break up when it reaehes its destination. It will therefore be seen that it is practically impossible to secme a single nozzle which is best for all purposes. The grower should have at least two styles, one for short range and one for long range. The Cyclone types of nozzles are generally best when a rery fine spray is desired for short range (eonsult Fig. 70).

Remarks similar to the above may be made for pumps; that is, there is no one best pump. We might divide all pumps into two general classes,those which deliver the liquid by force of gravity,

Note. The pictures of spraying machinery (Figs. 70 to 75 , pages 362 to $36 \%$ ) are inserted only for the purpose of familiarizing the reader with a number of the different types of inventions which are useful in the work. They are not inserted for the purpose of recommending any of the derices, and there are many other machines, which are not shown in the engravings, which are equally as good.

Fig. 70. 1, 2, Cyelone Nozzles. 3,4, Vermorel Nozzles. 5, Double Vermorel. 6, Longshank Vermorel. 7, Bordeaux Nozzle. 8, Undersprayer (Boekel). 9, Y for two nozzles. 10, Carnation Nozzle (Gould). 12, same, with pole attachment. 11, Masson Nozzle (Gould). 13, MeGowen. 14, Graduated Spray. 15, 16, Lilly (Rumsey); 18, same, with long tube. 17, Calla (Gould). 19, Boss (Field Force Pump Co.). 20, 21, 22, Nixon Nozzles. 23, 24, Winkle Nozzle.

Fig. 71. 1, Galloway Knapsack. 2, Garfield (Field Force Pump Co.). 3, Deming Kerosene Emulsion Knapsack. 4, Eclipse (Morrill \& Morley). 5, Excelsior (Stahl). 6, Dandy (Rumsey). 7, Douglas emulsion. 8, Knapsack at work. 9, Obsolete type of pump on a knapsack tank. 10,11, 12, Wonder Pumps (Lewis). 
as many of the potato sprayers do, and those which deliver it by the force of the pump. We have now come to believe that the force of gravity is not sufficient to do the work well, especially when Bordeaux mixture is to be used. Of the pump machines, there are several kinds, as those which derive their force from the suction of a piston and valves, and those which work from the force of compressed air. The accompanying illustratious (Figs. 70-75, pages 362-367) will show the reader some of the forms of puinps which are now manufactured, and will perhaps enable him to make an intelligent choice for his purpose. It may be said that knapsack pumps are very efficient, not only because they are powerful for their size but also because they enable the operator to stand very close to his work; but they are not adapted to work upon trees nor, in fact, upon large areas in this country, because labor is too high priced. For small areas, for experiment

Fig. 72. 1, Eureka Knapsack (Boekel). 2, Success Bucket Pump (Deming). 3, Common Bucket Pump. 4, Dart Bucket Pump (Gould). 5, Success Kerosene Bucket Pump (Deming). 6, Aquanette (Douglas), 7, Double-acting Aquanette (Douglas). 8, Handy eart rig. 9, Cart Sprayer (Field Force Pump Co.). 10, Economy Garden Engine.

Fig. 73. 1, Barrel Pump (Field Force Pump Co.). 2, Barrel Pump (Douglas). 3, Columbian (Douglas). 4, Double-acting Pump (Gould). 5, Nixon Tripod Pump. 6, MeGowen's Automatic Poison Injector. 7, Clock Pump, and Dash Agitator (Gould). 8, Bean Pneumatic Pump. 9, Myer's Lever Bucket Pump. 10, Barrel Agitator (Gould). 11, Maud S. Pump (Maud S. Co.).

Fig. 74. 1, Empire (Field Force Pump Co.). 2, Eclipse (Morrill \& Morley).' 3, Pomona (Gould). 4, Double Cylinder (Rumsey). 5, Geiger Pump. 6, Florida (Rumsey). 7, Columbia (Columbiana Co.).

Fig. 75. 1, Victor Outfit (Field Foree Pump Co.). 2, Caswell Sled Sprayer. 3, Caswell Geared Sprayer. 4, Wagon Outfit (Morrill \& Morley). 5, Mounted Barrel Sprayer. 6, Eureka Tank Outfit (Morrill \& Morley). 


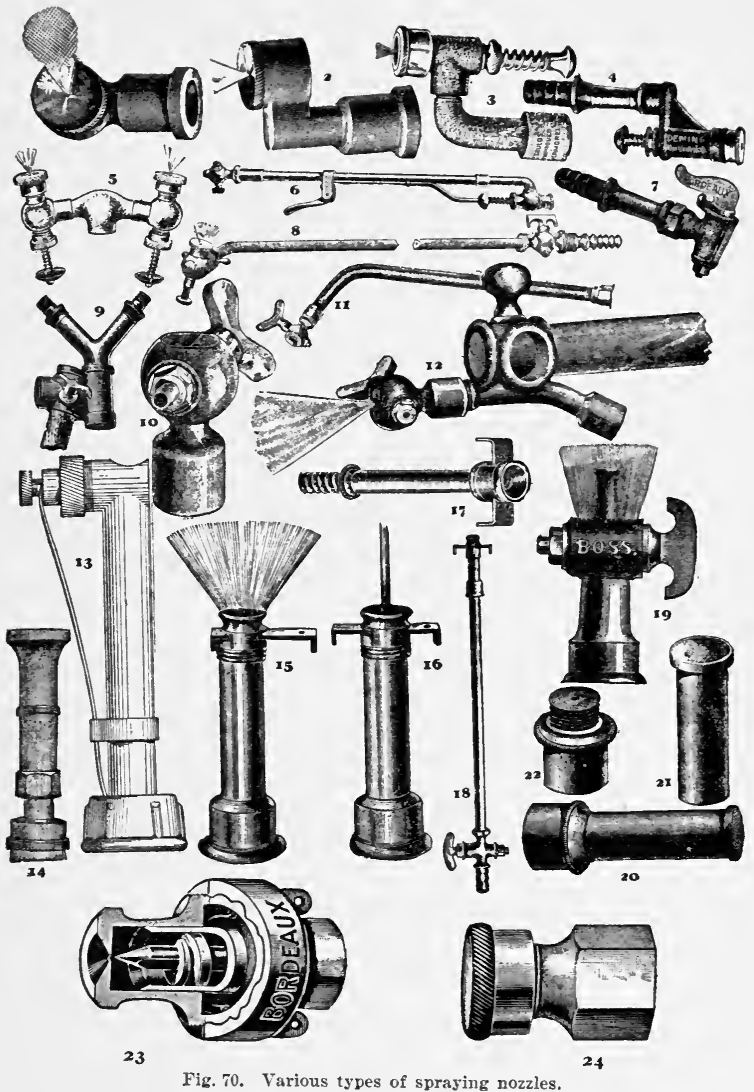




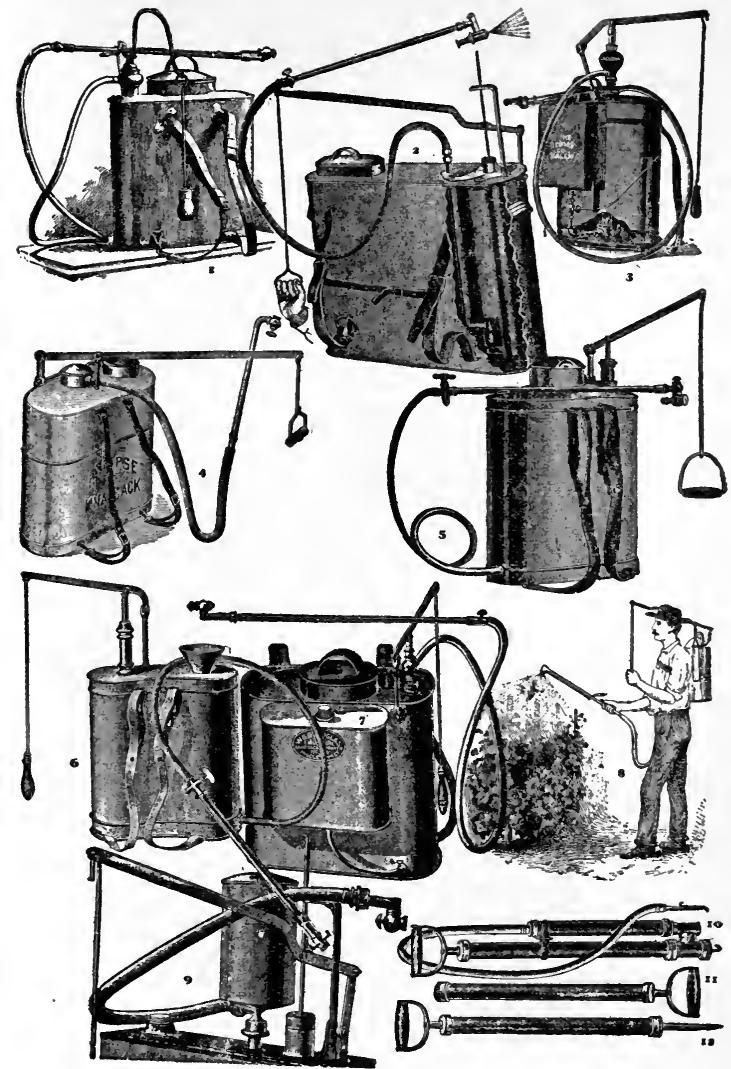

Fig. 71. Knapsack and syringe pumps. 


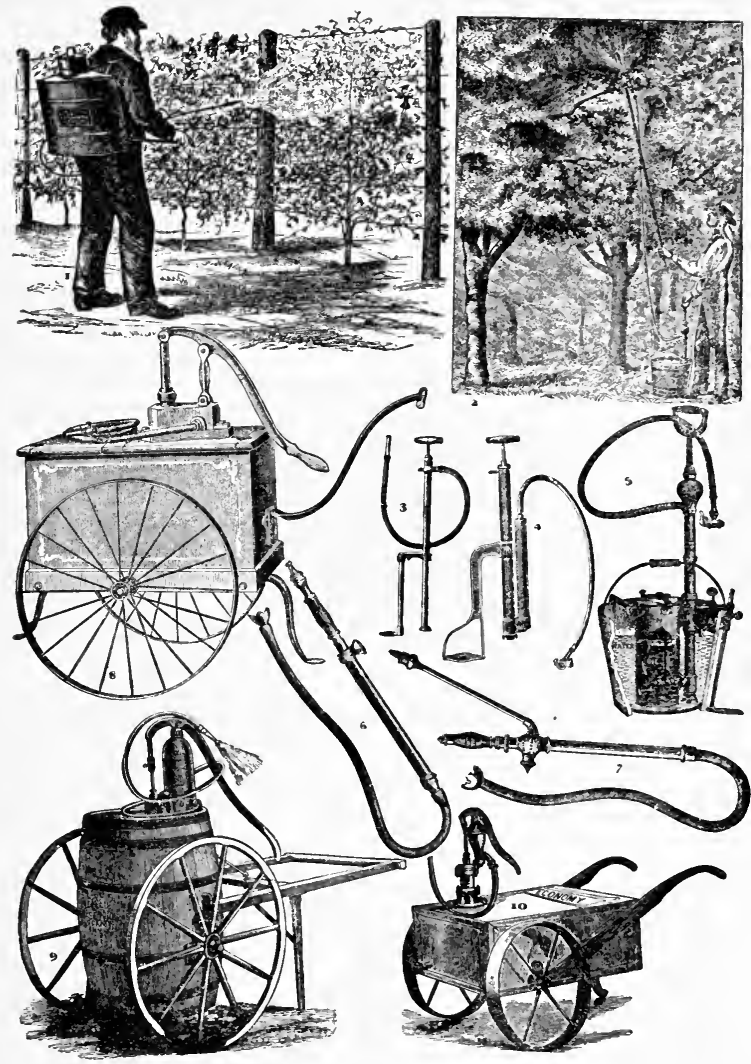

Fig. 72. Garden sprayers of various patterns. 


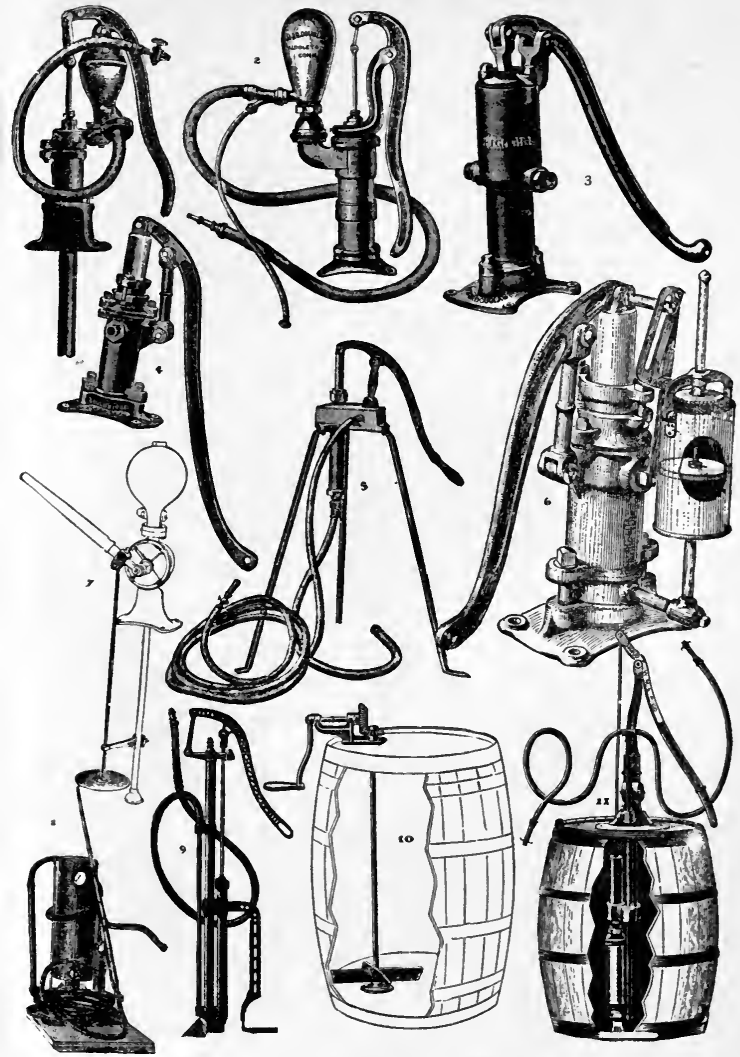

Fig. 73. Pumps for heavy orchard work. 


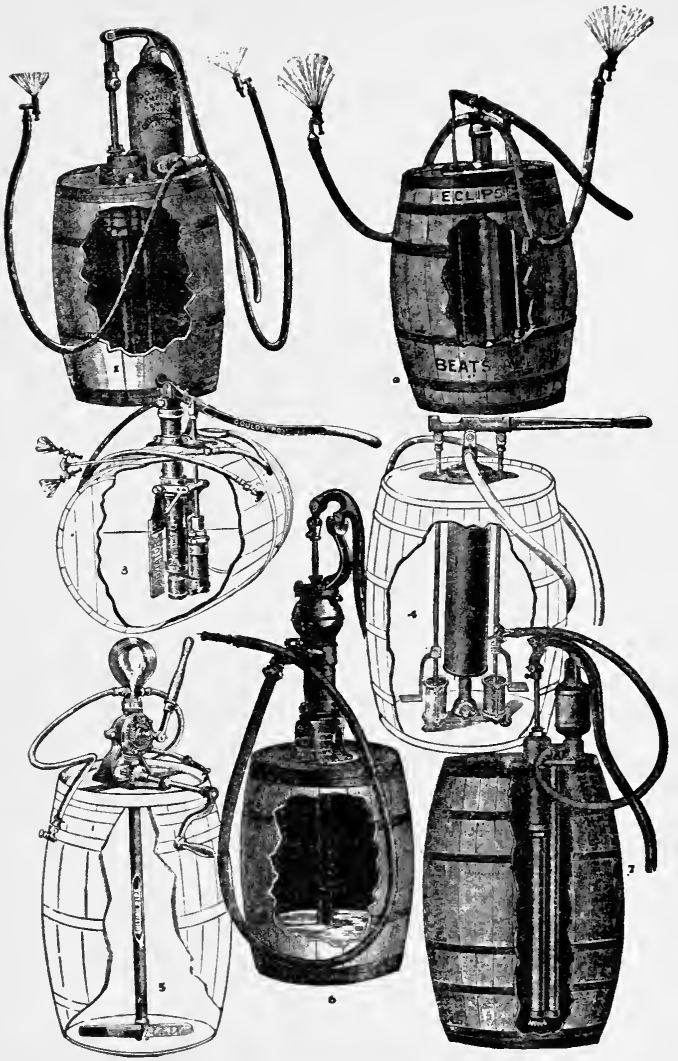

Fig. 74. Barrel outfits for heary work. 


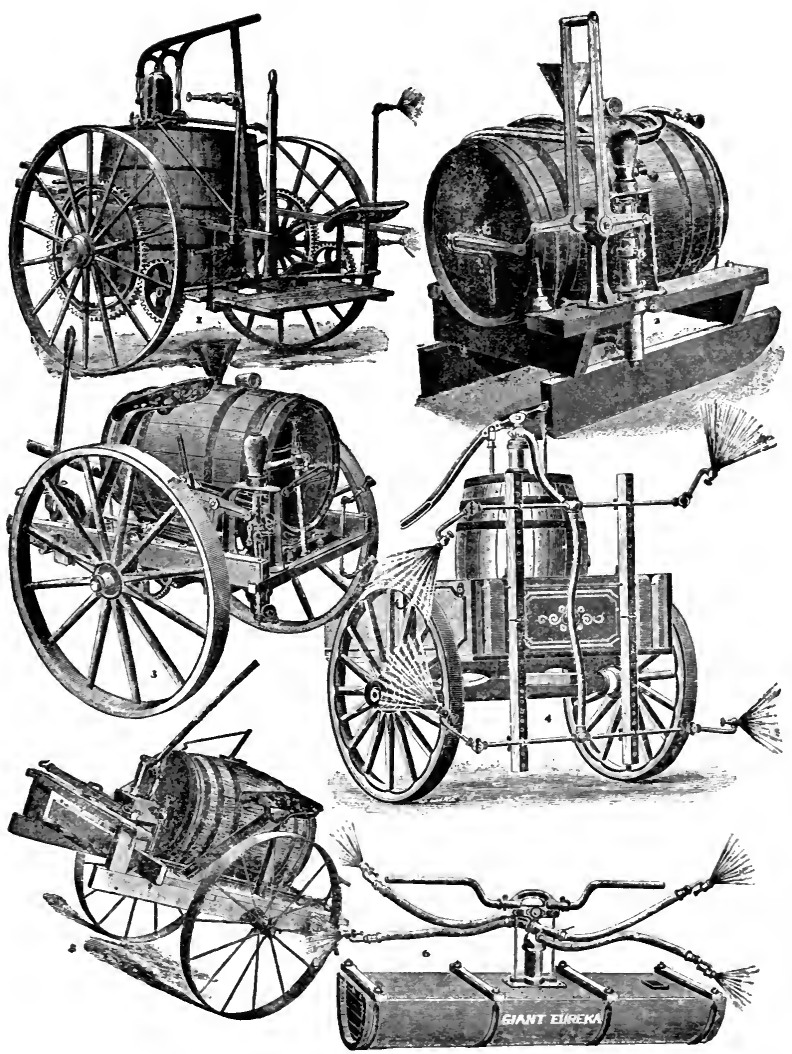

Fig. 75. Power and tank outfits. 
purposes, and the like, they are exceedingly useful and handy. The syringe and bucket pumps are very efficient for work upon a small scale, and especially when it is desired to be extra thorough. The greatest difficulty with the bucket pump is that the amount of material which can be carried is very small. The power sprayers (those which work from the wheel of the vehicle) are useful for vineyards, dwarf pears and low-growing plants; but, as a rule, they are not adapted to large orchard trees, becanse enough liquid camnot be thrown whilst the machine is passing a tree to thoroughly spray it. For very large areas and very tall trees (as street trees) steampower sprayers are coming into use.

7. The farmer should know what he rants to kill before he begins to spray. - It is common to find a man who is going at spraying with enthusiasm, but who cannot explain a single definite object which he has in view. He simply knows upon general principles that spraying is useful. To such a man, spraying is spraying, whether he uses Paris green, or Bordeaux, or both, or neither one; and his results are about equal to his knowledge. There is no longer an excuse for such ignorance, for all the leading insects and fungi have received more or less exact treatment in the publications of the experiment stations. The state of knowledge is far in advance of the state of practice. Many fruit-growers demand such elementary instruction as this:

The arsenites (Paris green and London purple) are used to kill all larræ or worms, and all those 
insects which chew the leaves or shoots, - such as the codlin-moth, bud-moth, canker-worm, potatobeetle, tent-caterpillar, and the like. Kerosene emulsion* is used for scale-insects and plant-lice. Bordeaux mixture and ammoniacal carbonate of copper are used to prevent the attacks of fungous parasites, as apple-scab, leaf-blight of the pear, quince and plum, potato-blight, and such like. Bordeaux is the better all-round fungicide, but the copper carbonate solution $\dagger$ does not discolor the fruit, and may therefore be used if very late sprayings are necessary.

The times and seasons of spraying depend entirely upon the enemies which it is desired to reach, and upon the weather.

8. The time to spray must be determined for each particular case. - The grower himself must decide when and how often to spray, because he should

* kerosene emulsion.

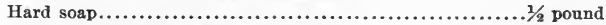

Boiling water (preferably soft water) ................. 1 gallon

Kerosene ........................................ gallons

Dissolve the soap in the water, add the kerosene, and churn with a pump for 5 to 10 minutes. Dilute 4 to 25 times before applying. Use strong emulsion (diluted 4 to 9 times) in winter for scale insects.

Some of the recent pumps emulsify kerosene and water, and make a very efficient spraying material. One part of oil to 4 or 5 of water is safe on foliage, partieularly in sunny weather.

\section{† AMMONIACAL COPPER CARBONATE.}

Copper carbonate...................................1 ounce

Ammonia, enough to dissolve the copper.

Before making the solntion, the ammonia should be prepared as follows : Use $26^{\circ}$ ammonia, and dilute with 7 to 8 volumes of water. Then gradually add the necessary amount to the copper carbonate until all is dissolved. It is best treated in large bottles, and in them it will keep indefinitely. Dilute with 9 or 10 gallons of water. For same purposes as the Bordeaux mixture. 
know what enemies he desires to reach. If he has the bud-moth, he should spray with the first swelling of the buds, and if he has the plum-scale he should spray in the winter. But, leaving the special insects aside, it is safe to say that for the two staple enemies - the apple-seab and the codlin-moth - at least two sprayings should be given. It is not yet

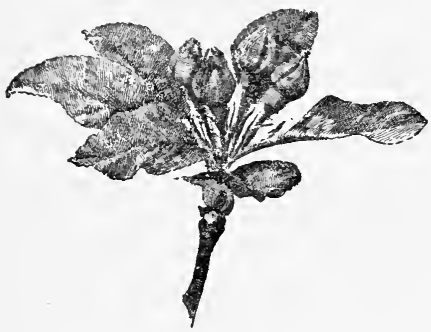

Fig. 76. Showing when apple treas are ready for the first spraying.

clearly proved that spraying when the tree is dormant has any appreciable effect in destroying the apple-scab fungus. As a general statement one may say, spray twice upon apples and pears, once just as the fruit-buds break open but before the flowers expand (Fig. 76), and again just as the last blossoms fall. In both cases, use a combination of Bordeanx mixture and Paris green. The first spraying is for the scab fungus in particular, and for this the Bordeaux is used; but the Paris green will most likely be of service in destroying various leaf-eating insects. The second spraying is for the codlin-moth in particular, and for this the Paris green is used; but the Bordeaux mixture will still be needed for the apple-scab and other fungi. Whether or not it is necessary to spray again will depend largely upon the season. 
The operator must watch matters closely, and spray when he needs to do so, or when he is in doubt. Two sprayings are sufficient for the codlin-moth, and three are generally sufficient for the apple-scab. These two sprayings constitute the insurance which has been mentioned; thereafter, the grower will be able to see more definitely what is needed. These remarks illustrate the nature of the questions which the fruit-grower must consider.

At any time when the tree is in growth, Paris green or London purple should be used with lime, or, better, with Bordeaux mixture, to prevent injury to the foliage. One pound of Paris green to two hundred gallons of water is the most serviceable general formula for that material; and to this a pound or two of lime may be added. A pound of Paris green (or London purple) may be added to two hundred gallons of Bordeaux mixture. If the Paris green is made into a paste with a little water, it mixes better in the barrel.

9. Prepare stock solutions for the Bordeaux mixture, * rather than to make each batch in the quantities

* NORMAL OR 1.6 PER CENT BORDEAUX MIXTURE.

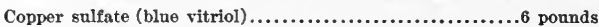

Stone lime ...................................... ponnds

Water. ..................................40-50 gallons

Dissolve the vitriol by putting it in a piece of coarse burlap and hanging this in at least six gallons of water, so that the bottom of the bag just rests in the water. Use a wooden pail or tab; vitriol eats tin. Pour the vitriol solution into the spraying barrel and fill the barrel about half full with water. Slake the lime and dilute it to make 10 to 15 gallons of milk of lime. Pour this into the barrel through a strainer and add water to make 40 to 50 gallons of Bordeaux. The formula 4 pounds of vitriol and 4 pounds of lime to make 40 to 50 gallons of Bordeaux is apparently equally efficient. If Bordeawx is to be used on peach foliage, apply it at one-half the ordinary strength. 


\section{The Principles of Fruit-grouing.}

called for by the formula.-The sulfate of eopper may be put into solution and kept in this condition indefinitely, ready for use. A simple method is to dissolve forty or fifty pounds of sulfate in as many gallous of water, pulverizing the material and hanging it in a coffee-sack in the top of the barrel. $A$ gallon of water, therefore, means a pound of sulfate. The lime may also be slaked and kept in readiness for use. Slake it into the ereamy eondition familiar to masons, eover lightly with water, and then close the box or vessel to prevent the water from evaporating. When making the Bordeaux mixture, pour the requisite quantity of the stoek solution of sulfate of copper into the barrel, and then dilute with four or five times the quantity of water. Now add the lime, and then add enough water to satisfy the formula. If the ferroeyanide test is used, place a spoonful of the mixture in a sameer or plate, and add a drop of the test solution. If a red color appears, the mixture needs more lime. If the test solution is added directly to a tank or barrel of the mixture, the eolor reaction is apt to be lost in the mass. An exeess of lime ensures the safety of the mixture.

10. How can one tell if soluble arsenic is present in Puris green?-It is the soluble arsenie whieh burns the foliage. This is present in London purple, but good Paris green should have little of it. Farmers are always asking how they ean determine if Paris green contains soluble arsenic. This may be determined by the use of the sulfur test. This 
test consists in adding sulfuret of hydrogen to a solution of the poison, when, if arsenic is present, a yellow precipitate (or sediment) will be thrown down.

In a bottle holding five or six onnces, place a quarter of a teaspoonful of Paris green. Add water until the bottle is nearly full; shake well, and then allow the material to settle. The clear liquid which remains on top will contain what soluble arsenic may be present. Carefully turn off this clear liquid into a long, slender bottle, or test-tube, add two or three drops of muriatic or sulfuric acid, then add a tablespoonful or more of the solution of sulfuret of hydrogen. If any arsenic is present in the elear liquid, a yellow discoloration will at once appear, and if the liquid is allowed to stand for a few minutes, patches or grains of a sand-like material will settle to the bottom. This yellow precipitate is sulfide of arsenic. If very little soluble arsenic is present, the sulfuret solution should be warm when used, for the reaction is then more delicate. The sulfuret is easily made by anyone who has had even an elementary instruction in chemistry, by adding sulfuric acid to iron pyrites.

This sulfuretted hydrogen is not a commercial preparation, but it is present in all sulfur mineral water, and the water sometimes gives the test. One can make sure of the presence of this material, for its odor is strong and offensive. It is the odor of spoiled eggs. If mineral water is used, it should be strong and fresh, and about equal in quantity 
to the arsenic solution; and even then only a faint amber discoloration may appear, because of the small amount of sulfur in the water. The mineral water test, therefore, is practically out of the question.

This test of arsenic determines only the fact that soluble arsenic is or is not present. It does not determine how nuch soluble arsenic there may be ; although the greater or less amount of the yellow "olor on precipitation will afford a comparative idea of the amount present in any two or more samples.

It has already been advised to use lime with Paris green or London purple for the purpose of taking up the soluble arsenic, by the formation of arsenite of lime. If this is done, or if the Bordeanx mixtme is used with the arsenites, it will not matter if the poison contains soluble arsenic.

11. Hou can one determine if Paris green is mure?-It sometimes happens that material which is ohtained as Paris green contains no arsenie. Chrome green may be sold instead. If the material is pure laris green, it will quickly and completely dissolve in common strong ammonia, giving a beantiful, rich, dirk blue, clear liquid, whilst any of the compounds which would ordinarily be substituted for Paris green on aroount of their color and textme, will not behave in this manner in ammonia. Any insoluble resiche is impurity. Chrome green will not dissolve in ammonia.

12. What becomes of the arsenic when it falls upon 
the soil?-With the action of the rains and the falling of the leaves, most of the arsenic which is applied to trees finally reaches the soil. What then becomes of it? If lime has been used with the spray, the arsenic will be insoluble when it falls. upon the soil. It is possible that the organic acids in the soil, and also earbonic acid, may dissolve some of the arsenic, but it would be almost surely made immediately insoluble again by combination with lime or other soil constituents. If soluble arsenic is placed on the soil, it probably almost immediately goes into insoluble combinations, and remains where it was placed unless slightly washed down by mere mechanical means. Now, some plants appear to have the power to take up very minute quantities of arsenic and still thrive-probably so minute that the nicest chemical test can scarcely discover it,-but any appreciable quantity of soluble arsenic in the soil quickly destroys the roots. If, therefore, the grass and other plants under sprayed trees continue to live, there need be no fear that the arsenic will injure the soil.

A study of the destination of arsenic which has been applied to the soil in the form of Paris green was made at the Cornell Station (Bulletin 101), from which the following conclusions were drawn: "The gist of the whole matter then, if we may generalize from these tests, is that the arsenites do not leach from the soil. They remain where they fall, the same as sand does, and are carried down only when there are crevices or other openings in the soil, and they then go down as insoluble compounds, and to 
a slight extent, by the mere mechanical action of the water. It is really remarkable that sand was such a perfect filter as to hold the great quantity of arsenic above a depth of three inches for over four months. If the soil in either experiment had been a homogenous subsoil, where the sun eould not have cracked or checked it, it is fair to conclude that no arsenic could have penetrated it."*

Summary - The fruit-grower may desire to have a very brief epitome of some of the eardinal suggestions touching spraying:

1. Spraying is only one of several means or operations which the pomologist must master if he aspires to the greatest and most uniform success. Other fundamentally important requisites are tilling, fertilizing and pruning.

2. Spraying is not necessary to successful results every year, but inasmuch as the farmer cannot foretell the need of the operation, he should spray as a matter of insurance.

3. Spraying is almost sure to be of some benefit every year, particularly upon apple, pear, plum and quince trees, and upon grape vines.

4. Spraying is of little consequence unless carefully and honestly done. The spray must actually reach every point which it is intended to protect.

5. Prepare for the rear's campaign during the previous winter, by reading the last teachings, and

* For another discussion of this subject, and of the destination of copper In the soil, see Lodeman, "The Spraying of Plants," 231-237. 
by completing pumps and appliances. Give particular attention to a convenient wagon outfit.

6. The Bordeaux mixture need not be made up at each using in the exact numbers of the formula. The copper sulfate may be permanently dissolved in water and the lime may be slaked. When the mixture is prepared, the stock solution of vitriol is diluted, the lime added, and the tank filled to the required amount.

7. Spraying is of small account unless the operator understands precisely what he sprays for.

8. The time to spray is when the operation is needed to protect the plant. This will vary, therefore, with every season and every different pest. In general, apples and pears need spraying twice, first when the fruit-buds open, but before the flowers expand, and again when the blossoms fall.

9. The presence of soluble arsenic in Paris green may be determined by a test with sulfuret of hydrogen.

10. Pure Paris green dissolves in ammonia, giving a rich, deep blue liquid.

Note.-Home-made arsenites of lime and soda are now nsed in some regions. Either ean be used with Bordeaux mixture. When used with water, it is safer to add freshly slaked lime.

Arsenite of lime is made by boiling one pound of white arsenic in two to four quarts of water until it is dissolved, then nse this arsenie solution to slake two pounds of good lime, adding water if necessary to slake it; when slaked, add water enongh to make two gallons of this stock mixture. This may be kept in a tight vessel and used as desired. Thoroughly stir the material before using. For most insects one quart of the above to forty gallons of water will be sufficient.

Arsenite of soda. The arsenie (one pound) may also be boiled with ferr pounds of sal soda crystals in two gallons of water until dissolved, and this solu. tion used in the same manner (with lime). 


\section{CHAPTER VIII.}

\section{HARTESTING AND MARKETING FRLIT.}

Althovgh the management of the business or commereial side of fruit-growing - the importanee of which is urged in the first chapter-is very largely a matter of personal temperament, nevertheless a fiw general remarks by way of suggestion may be given to the subject. The business part of fruitgrowing is chiefly eoncerned with the broad subject of marketing the fruit, which may be eonsidered under the four heads of picking, packing, storing and shipping. The actual selling of the product is an enterprise which belongs rather to the merehantman than to the fruit-grower.

\section{PICKING FRUITS.}

When to pick.-Just when and how the fruit should be picked for best market results depends very largely upon the speeies or variety of fruit, and greatly, also, upon the distanee to whieh it is to be shipped. The eloser and better the market, the riper the fruit should be when it is taken from the plant. If one is fortunate enough to have a special or personal market, delivering the fruit to 
the consumer direct, then he can hope to retain this market only by sending in the products in the very finest dessert condition. Such consumers are generally willing to pay a sufficient extra price for the advantage of having the fruit taken from the plant when it is in its highest state of edible quality. Most serious mistakes are constantly made in the picking of blackberries, for example. It is ordinarily considered that when the berries are black they are ripe, but such is not the case. They are fully ripe only when they shake from the bushes readily, and when they are soft and free from sharp acidity. In this condition blackberries ean be handled direct to the consumers in the local market which is only a few miles away; but they could not be shipped by rail. The strawberry is ordinarily picked for market when only a portion of the berry is really ripe, and when the organic acids are still too sharp and austere for the dessert. A strawberry which has a green or white tip is not yet in fit condition to pick, if one is expecting to reach a really good market.

With the tree-fruits, it may be said that in general the samples keep longest when they are picked greenest, but they suffer thereby in point of quality. There are no well-marked lines between greenness or immaturity, ripeness or full maturity, and over maturity and decay. The one stage passes into the other insensibly, and it is a part of the normal chemical history of the fruit that it should begin an incipient breaking down and disorganiza- 
tion of tissue as soon as the ripening process is thoroughly complete. It will be seen, therefore, that the riper the fruit, the more nearly it approaches this period of disorganization, and the sooner the breaking down of the tissues may be expected to begin. When the fruit is picked very green, however, this period of natural disorganization is comparatively remote. On the other hand, fruits which are pieked very green are not yet arrived at their most edible stage, and unless they are kept in the most favorable conditions, they are very likely to shrivel and to beeome unmarketable.

In the case of apples, it is generally best to pick them, if they are to be stored or exported, just as they have arrived at their full size and when they have attained only a part of their full color. Overripe or fully ripe fruits must be sent to the market at once, or else they must be kept in artificial cold storage in order to thoroughly stop the chemical processes within the fruit, and when they are taken from storage they are very likely to soon deeay. Apples which are picked slightly green, however, generally continue to keep well after being taken from eold storage. This was demonstrated at the World's Fair at Chieago, at which New York apples taken from cold storage remained upon the shelves in good eondition for several weeks.*

Pears, on the other hand, nearly always lose quality by fully ripening upon the tree. The cells of the fruit fill up with gritty mineral matter, mueh

* Annals Hort. for 1893, 67 . 
to the detriment of texture. It is ordinarily considered that the best time to pick a pear of any variety is just as soon as it reaches its full size and before it has begun to color. In most varieties, this stage is pretty well indicated by the facility with which the fruit stem parts from the spur. The pear is taken in the hollow of the hand and turned up; if the stem snaps off from the spur at its point of articulation, the fruit is generally considered to be-ripe enough to pick. The pears are then ripened under cover. The best place in which to ripen them is a rather cool but dry room, like a loft or a ehamber. Here they are piled upon the floor or upon racks, and they should not lie, for the best results, more than three or four pears deep. If they are piled too deep, the lower ones are likely to be indented by the weight of those above them. The room should be kept fairly close. If there is too much circulation of air, and if the temperature is high, the pears ripen too quickly, and often shrivel. A Bartlett pear, when properly picked and handled, ordinarily requires a full week in which to ripen up to its best quality, and the ripening process may often be continued considerably longer than this by picking the fruit early and keeping it cool. Kieffers, especially if grown in the north, seem to ripen best if they are stored in bulk, like beans, two or three feet deep, or even in barrels, and the ripening process is ordinarily two to three weeks long. If they are given this long time in which to mature, the quality may be 
experted to be very much better than it is in the general run of samples.

$A$ peach is fit to pick when it is full grown and hats begun to develop its characteristic color. Peaches and apricots do not ordinarily color up well after they are picked, although plums usually will to so, especially the Japanese plums, which may be picked very green and yet develop a high color. It is very difficult to describe that period of maturity at which a peach is ready for picking. An experienced picker will take the fruit softly in his hand and press the ball of his thumb very lightly upon the side, and if the fruit has a somewhat springy fecling, it is ready to take off the tree. This pressure is never sufficient to leave any mark upon the fruit. Pinching a peaeh will almost always spoil it. If the peach is too green, it will feel hard and stone-like. If it is too soft, it will simply indent, and will not have the elastie feeling whieh is mentioned.

In the case of cherries and plums, it is very important that the fruits be picked just before they have reached their condition of most edible quality. This is largely because the fruit-rot fungrus is very likely to destroy the fruits at the time of their ripening, especially upon those varieties which are particularly subject to the disorder. Amongst plums, the Lombard is one of the most seriously attacked; and amongst cherries, nearly all the white-fleshed ones, like Governor Wood and Napoleon, are greatly subject to injury. If the 
weather at picking time gives promise of being close and warm or muggy, then it is exceedingly important that the fruit should be picked early. In sweet cherries, a delay of a few hours will sometimes result in the loss of an entire crop from the fruit-rot fungus. Cherries and plums should always be picked, if possible, when they are perfectly dry. This is especially true of the sweet cherries. If they are picked when they are wet, and put into boxes or baskets in this condition, they will be almost certain to decay before reaching the market, unless the weather remains very cool.

This fruit-rot fungus is very serious upon many stone fruits. In cherries, "the losses from this disease which have come under my observation are invariably the result of letting the fruit hang on the trees till ripe, and then the rot is very active; but cherries should be picked a few days before ripe, before they soften, and then the rot does not seriously affect them. An illustration of this point, which is a most important one, was brought to my notice the present season. The last week of June, in eastern New York, was very hot and close, with showers every day or two. The cherries were then ripening, and the conditions were favorable for the rot to spread. In one orchard, from which several tons of cherries were shipped that week, there was not more than one hundred and fifty pounds destroyed by the rot, while in another orchard a few miles distant at least ten tons of the same varieties were ruined on the trees. In the first 
orehard the fruit was picked before it had ripened, and all that was fit was taken off as soon as the trees dried off after a shower; in the other orchard it was left till nearly ripe, and one-half to two-thirds of the crop was lost before the fruit conld be picked. So rapid is the work of this fungus at this period, that the owner of the orchard told me that he lost three tons of one variety in one night. It might be added that the orehard first mentioned was a mueh stronger one, as it was in cultivation, while the last had been in sod for years, and the general debility and neglect of the trees made them good subjeets for the attacks of rot or any other disease." $*$

How to pick.-In picking the soft fruits, like cherries and plums, the operator grasps the stem and not the fruit itself. In this way he does not remove the delicate bloom, and does not injure the fruit when pulling it from the spur. In the case of grapes, it is likewise very important, especially in those which have a heavy bloom, that the picker should not grasp the bunch itself, but should take the cluster by the stem and suip it off with shears (which are made for the purpose). In the case of peaches and apricots, this precantion, of course, need not be taken, because the stem does not naturally alhere to the fruit; but the operator must be very careful, when picking these fruits, not to grasp them too tightly, otherwise he will bruise them and cause

*G. H. Powell, Bull. 98, Cornell Exp. Sta. 410. 
them to become discolored. The picker must always bear in mind that every evidence of fruits having been touched by the hands detracts from their market value. Strawberries should always be picked with the stems on. A berry which has the hull pulled out is not fit for the market. The picker should grasp the stem itself and pinch it off between the thumb and the finger.

Upon all fruits which grow on a distinct pedicel or stem, this stem should be allowed to remain. Pears which have the stems pulled out or broken in two are never first-class fruits, no matter how good and uniform the specimens otherwise may be. This is even true of apples when they are put up for the finest dessert trade; but as they are ordinarily handled, very little attention is paid to leaving the stems on. Leaving the stems on is vital to the handling of plums and cherries, not only because the market demands it, but because the fruit will be very likely to rot if the stems are pulled out, and they will not pack so snugly, and will not stand the transportation so well. The stems of cherries, plums and currants, and the hulls of strawberries, serve a most useful purpose in holding the fruits in place in the box or basket, and in taking up the slack from settling or shrinkage.

A word may be expected in respect to the exact methods of handling fruit in the field. It is only in rare cases that fruit should be sent to the market in the packages in which the pickers place it; that is, it will need to be sorted from these 
parkiges into others, and this sorting should be done in a rool shed or packing room. In the pick-

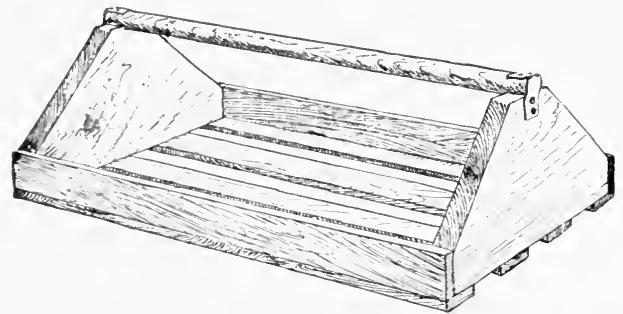

Fig. 77. Dundee berry stand.

ing of small finits, various kinds of trays or stands are used. In strawherries, it is important that these stands should have legs, so that when the package is sot down it will not crush the berries. and neither will it be so likely to tip over. Such

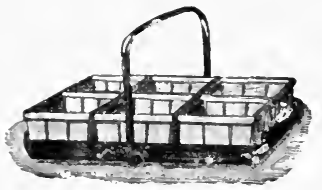

Fig. ix. Berry-tray mate of theet. iron, with band-iron handle. stands are handy for grapes, or for any kind of berry fruits as well. Fig. 77 shows a type of berrystand whirh is largely nsed in parts of Sew York for the pirking of rasplerrexis and blarkberries. This stamd loolds six one-quart boxes, and a tier is rasily starked npon another, one tire or layer of stands buaking joints with those above and 
below. Other types of berry-stands are shown in Figs. 78, 79 and 80.

In the picking of tree-fruits, it is ordinarily best to use a basket and not a bag, for in spite of all one can do, the fruit is bruised when it is thrown into a bag which is slung over the shonlder. In the picking of peaches, it is customary to pick in something like a Climax basket, or better still, in the old-fashioned tall, round-top peck baskets, such as are standards in New Jersey and other places. These baskets are held at about one's

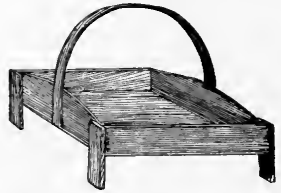

Fig. 79. Berry-stand on legs.

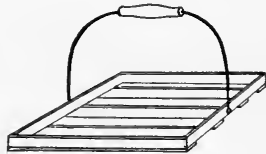

Fig. 80. Tray for berry boxes.

middle by dropping them into a hoop which is held upon the person by a strap running over the shoulder and under one arm (Fig. 81). This allows the picker the free use of both arms, and obviates the necessity of his being obliged to stretch or stoop to deposit the fruit after he has picked it. The baskets are filled about level full, all the fruits which are ripe enough for picking being saved indiscriminately. The basket is then set in the shade alongside the tree from which the fruit was taken, and at intervals a wagon or cart collects the baskets and takes them to the packing-room, where 
the frut is sonted, grabled amel partion. In the prokinge of apples, the best method is omblinarily to nse a half-bushel, romul-lottomod splint (not woven) hasket whioh has a swinging handle. If this basket

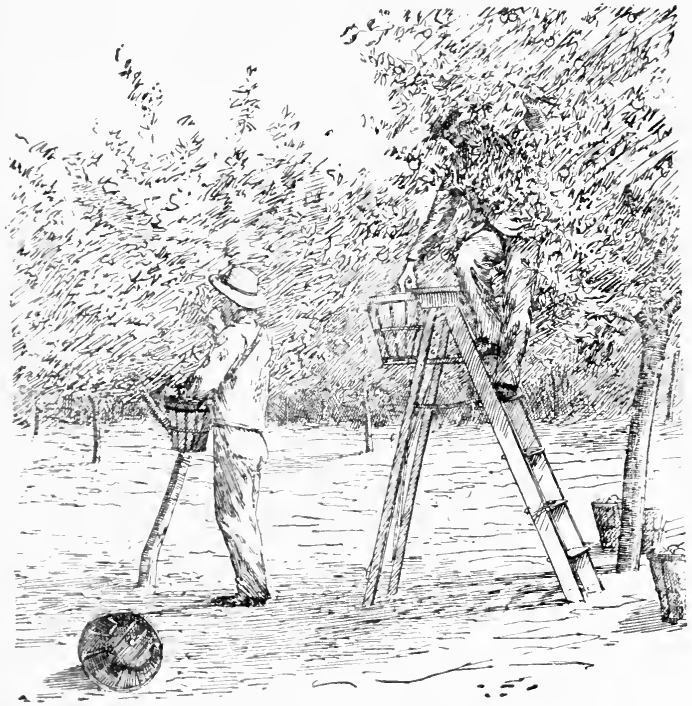

Fig. Bl. Pieking pearhes.

is linerl on the inside with thick roth or burlaps, it will answer the purpose all the better. This basket is poovided with a stromg wire hook, that (an be hume upon a limb, allowing the piokere to 
have both hands free. There are various special practices to facilitate apple-picking, which are not proper subjects for discussion in a general fruitbook.

There are various appliances which may be used in the field to facilitate the picking of fruit, some of which may be briefly mentioned. In the first place, the fruit picker shonld provide himself with an ample supply of erates or baskets, or whatever other receptacle may be used in the field. These receptacles should be strong and durable, so that they may be used year after year; this is especially true of the baskets and crates which are used for the picking of the heavier fruits, like pears, apples and grapes. It is generally advisable to take the fruits to the packing house in the very baskets or boxes in which they are placed from the tree, thereby avoiding unnecessary handling of the fruit. In the ease of winter apples, however, it is sometimes admissible to earefully pour the apples from the roundbottomed baskets, into which they are picked, into bushel baskets, or sometimes into crates such as are used for potatoes. In any case it is always advisable, in the best quality of fruit, to have all these baskets or crates lined with burlaps.

The best wagons for use in orehards are those which are of the platform style, with low and very broad-tired wheels, and the platform extending over the wheels. Such wagons are not only capable of carrying a very large load, but do not eut up the ground; they are easily drawn and managed, and 
they escape the limbs in low oreharels. It is desiralle that the front wheres should turn under the platform, in order that the wagon may be turned at sharp angles. The pratetiee of loading apples and other fruits into a wagon box in bulk amuot be too strongly depreseated. It is only admissible when the apples are of low chality, and are fit only for sale as second and third grades, or for manufacture into cieler, evalporated stock, or oflere products.

The strles of ladelers to be nesed must depend directly npen the height of the trees. In old apple orehards, it is nearly always essential to have long and light ladders, with a sharp or poaked top, which "an be run direstly up into the top of the tree and find lodgment against the branches. Extension ladder's are also nsed, but they are usually more (ommbersome and more difficult to manage than the light pointertopped implement which is here mentioned. In most other orehards, howerer, a step-ladder of the ordinary pattern, but perhaps somewhat taller (rmming from ten to even twelve feet high), is all that will be required. This ladder should have a flat top, and also a movable shelf npon its back, where baskets may be placed. The facility of picking fruit is rery morh increased if the trees have heren well trained and promed. Dwarf pears shonld rarely rach a height of more than twelve or fifteen foest: and if pear and apple trees are planted suffiriently far apart, and are kept open at the base, the pirker's an reach most of the fruit by alimbing. In the pieking of apple's and pear's, there is nothing 

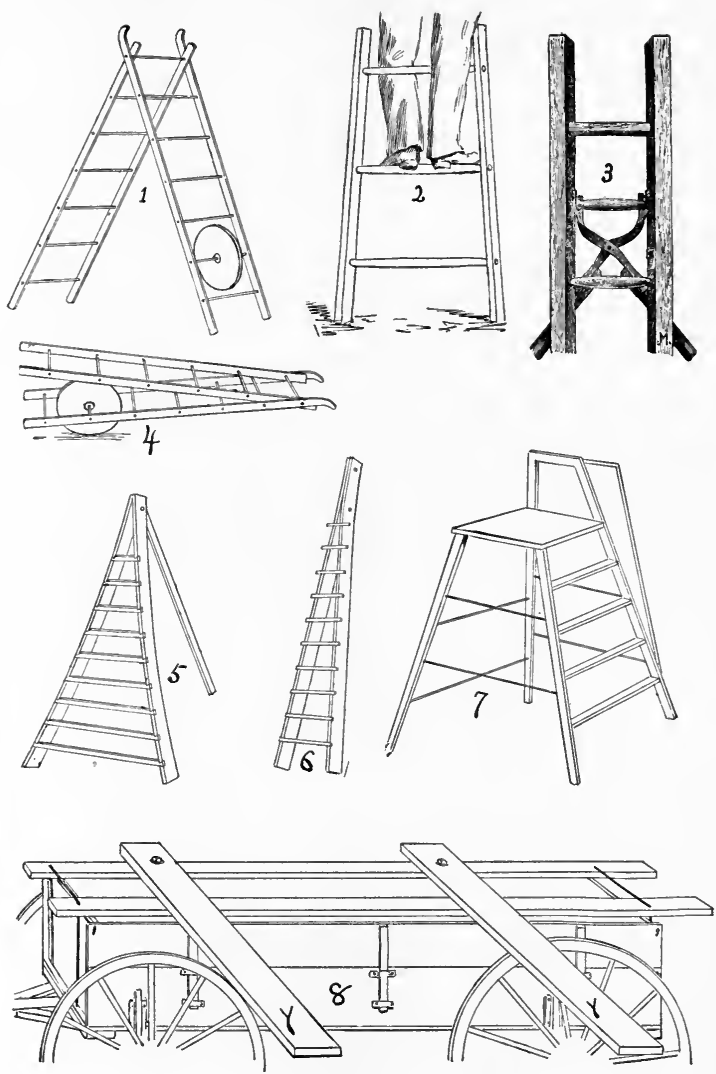

Fig. 82. Various types of ladder arrangements. 
which answers the purpose so well as a strong, nimhlo log who is not afraid to climb. In many orchamds, the long and emmbersome ladelers may be almost antimly dispensed with if this requisite is at lannel. For gerting into the tops of fruit trees, a short and very light ladeler with three or four roungs is rxoedingly nseful. This little ladeler will also aid greatly in the gathering of fruit which hangs npon the lower limbs just ont of the rearell of the pirker. The lateler is stoot upright and the pieker monnts it puickly. ressing his legs orer the top one or twe romes, and holels himself ereet by grasping a limb, ahove his head, as shown in the illustration (2), Fig. s.2, palge 391). This is a type of lateler which is much nsed by professional top-ganters.

The vardons kinds of fruit-pioking devices which ase mon the market are nseful only for gathering the few outlying fruits mpon the tall and far-reaching limbs. It is nerer practionhle to use them for the pirking of the entire crop, except in those very rase rases in whioh the rop is small and all the fronits are fit for the dessert trate. The labor of pieking with these devios is slow and onerous. One of the best types of fruit-piekers is shown at 5 in Fig. 83.

Notr. - I variety of ladders is shown in Fig. 8. . No. 1 is a light ladder with a wheel, allowing it to be wheeled like a wheelbarrow when it is shut up, as at $4 ; 2$, the short lubler, not requiring support, deseriled in the text aluse ; 3 , a tierman device for securing a support to a larlder, allow. ing the two supporting legs to be shut together; 5, a pointed ladder, with support: 6 , similar ladder, without support (very useful in tall trees); 7 , plat form laulder: $x$, wagon rigged for pirking, the planks $y, y$ (upon which the bicker stands) being swumg aroum lengthwise the box when alriving from tree (o) tree. 


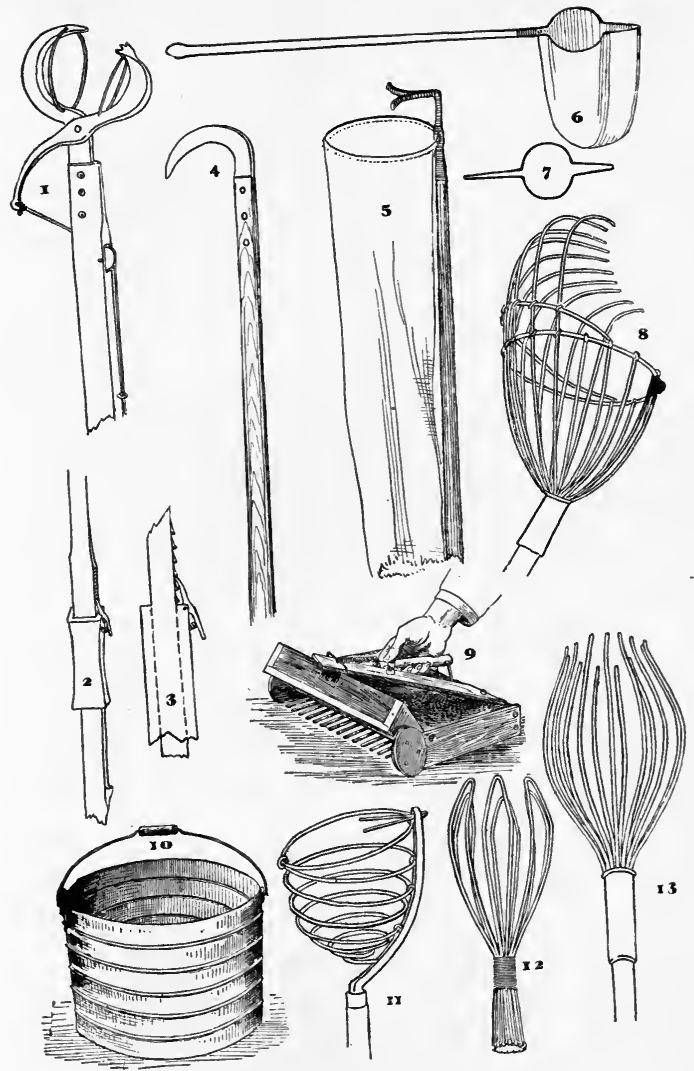

Fig. 83. Different implements for picking fruits. 
which may be mate hy any hamely man. The fruits

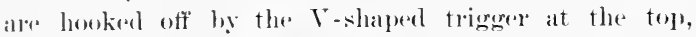

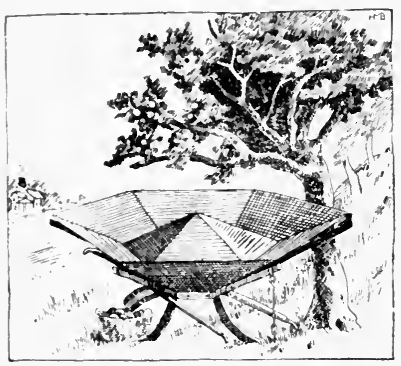

Fin. Xl. Cook's apple pirker. and are delivered to the pieker thromgh the ranvas or hurlaps hatg which extenels along the landle. Of course, only one fruit shombl be allowed 10) go threngh the bag at a time. Anothere very handy device is the fingere picker, illustrated at No. 13. This may be made by any hamely tinsmitl, who, how"ver, shomlel be antioned against making it too heary ant (*monbersone. In this instanee, the apple is deliv(reel to the pirker by taking down the instrument. 'The thisalvantage of this toul is that the fingers are apt to spriner with use, and the apple will pull through between them rather than be pulled off. There are also deviees in nse for eatehing the fruit when it is shaken from the tree or hush. These are usually upon the prineiple of a soft cloth hopper

Notr.-Key to Fig. 8. : No. 1, picker composed of two pincer-like jaws, with wire ghards to reenive the fruits, the jaws being closed ly means of a eord, which is worked below ( 2 and 3 ) ly a catch ; 4, hook used for cutting off the fruits (therurved etlge being slunp); 5, V-picker with delivery suck; 6, Bag-picker, humg on a wire frame (as shown in $7 ; x$, a wire finger-pieker : 9, cranberry bieker : 11, 6-quart eranleerry measure ; 11, 12, 13, forms of wire pickers. 
(see Fig. 84). Such machines are often very useful in the gathering of black currants and gooseberries. For these purposes inverted umbrellas are sometimes used. Cherries are sometimes gathered by being shaken into the machines used for the eatching of curculios. It is needless to say that these

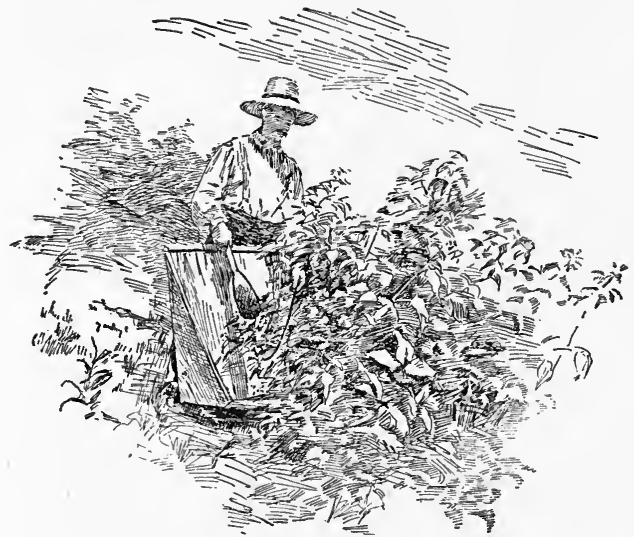

Fig. 85. Batting the berries.

means of gathering fruit are advisable only when the fruit is to be manufactured into some commercial product, or when the price of fruit is extremely small.

To lessen the cost of harvesting, and to overcome the difficulty of securing pickers in remote places, a harvester for raspberries has come into use 


\section{The Primeiples of Frut-groming.}

in Now York state.* This is a canvas trat, made by stretehing the roth over a light wooken frame shout three feect with and fomr or five feet longe At the hottom, the frame projerets upwarels at right angles to the body of the frame to a distance of fire or six inches, to eatch the berries as they fall upon the eanvas. A wooden shoe or rumer is placed on the bottom of the apparatus, to allow the operater to slide it along from bush to bush, as shown in Fig. 8.5. A long wire hook (Fig. 86) is used to pull the bushes over the tray or to lift up the fallen annes, whilst with the other lamel the operator deftly auffs off the berries with a paddle of wood of of wire eovered with anvas and about the size of a butter ladle.

The harvester is used only for the gathering of berriess which are to be evaporated. The berries are allowed to berome fully ripe,

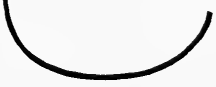

Fig sit, Batter's hook.

so that they fall easily, and the pat rh is gene over about three times. Mueh litter falls with the berries, but this is readily removed by romning the doied fruit thromgh a fanning mill. There are few growers who nse this harvester exchusively. It is often hrought into requisition for the last pieking, or in seasoms of low priees, and it also has a most stimulating effect 10 pon a lot of disaffereted berry piekers. The deviee was first perfected by Mr. Benedict, of Inudee, New York, although

* Bulletin 100, Cornell Exp. Sta. 
the idea seems to have originated with Uriah Hair, of the same place.

After fruit is picked, it is very important that it should be kept cool and away from the direct sun. This is particularly important with the soft and berry-like fruits, like grapes, strawberries, cherries and peaches. The fruits not only ripen up rapidly after they are picked if the sun strikes them, but they may also become so warm that they will not withstand shipment. It is ordinarily best to pick the perishable fruits early in the morning, if they are dry, and then to pack them up tight and send them directly to the railway station; or, if they have become too warm, or if it is desired to delay the shipment, then they should be put in the cellar or a cold storage in order to reduce them to a low temperature. If the soft fruits, like strawberries and raspberries, are treated in this way, they will ordinarily endure shipment best if they are sent in tight, unventilated crates. Apples ripen up very rapidly in the pile if they are exposed directly to the rays of the sun. It is always well, therefore, if they are piled in the field, to place them on the shady side of the tree, if possible; but, no doubt, the very best results in long-keeping qualities are obtained when the apples are taken directly from the trees to a cool room and there kept in storage, where the ripening process is wholly or partially cheeked. This is especially important if they are to be shipped long distances, and particularly if they are to be exported: If the weather is cool and somewhat dull at the picking 
time, this precantion is not so essential as it is in falls which are dry, hright and warm.

kepping records with the pirliers.-There are various methods of keeping acoounts with berry pickers. Perhaps the rommonest mode in large patehes is a simple ticket, like Fig. 87 , which is given to the picker in exchange for the berries which are delirered. There are tickets of various

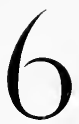

C. H. Gould.

Fig. 8i. Picker's tirket. denominations, the figures rep. resenting quarts, so that any number of quarts can be represented by combinations of tickets. These tickets are so often lost that they may soon come to be a nuisance, although some growers prefer them for this very reason, for all that are lost do not have to be redeemed. Several growers, therefore, have designed tirkets which ran be tied to the person ly a string, which bear the pieker's name, and in whieh the numbers are cancelled by a pumeh. Two good styles are shown, half-size, in Figs. ss and 89. In the latter are two stylus of punch marks, representing different foremen. Other grower's abolish all tirket ststems outright, and kees) a book acoount with earh picker; and, what is better, they pay by the pound. A small, flat-topped groeers' sale may be taken to the shed in the berry field. Earh picker is numbered, and he pielis in an eight-pound or ten-pound climax 
grape basket. As he comes to the shed, he slips his number into the basket on a bit of card or splint, and he sees the basket weighed and the credit given; or, if the picker has no suspicions, the foreman may gather the baskets from the field. Growers generally pay 2 cents a quart for raspberries, or 1.6 cents a

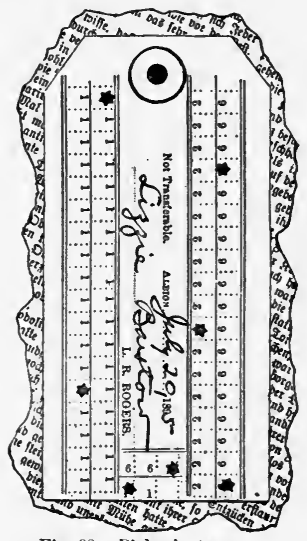

Fig. 88. Picker's tag.

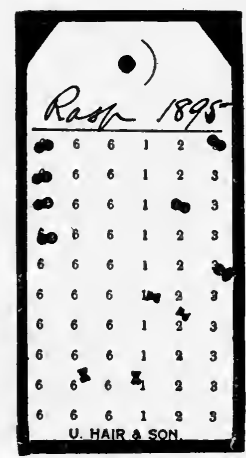

Fig. 89. Picker's tag.

pound (since a quart weighs $1 \frac{1}{4}$ pounds), but the price ean be dropped to 1 cent a pound in some varieties and in good picking.

In the picking of fruits, it is always essential that each picker finish the particular job to which he is assigned. This is especially important in the smallfruits, for the picker must follow a certain row, and 


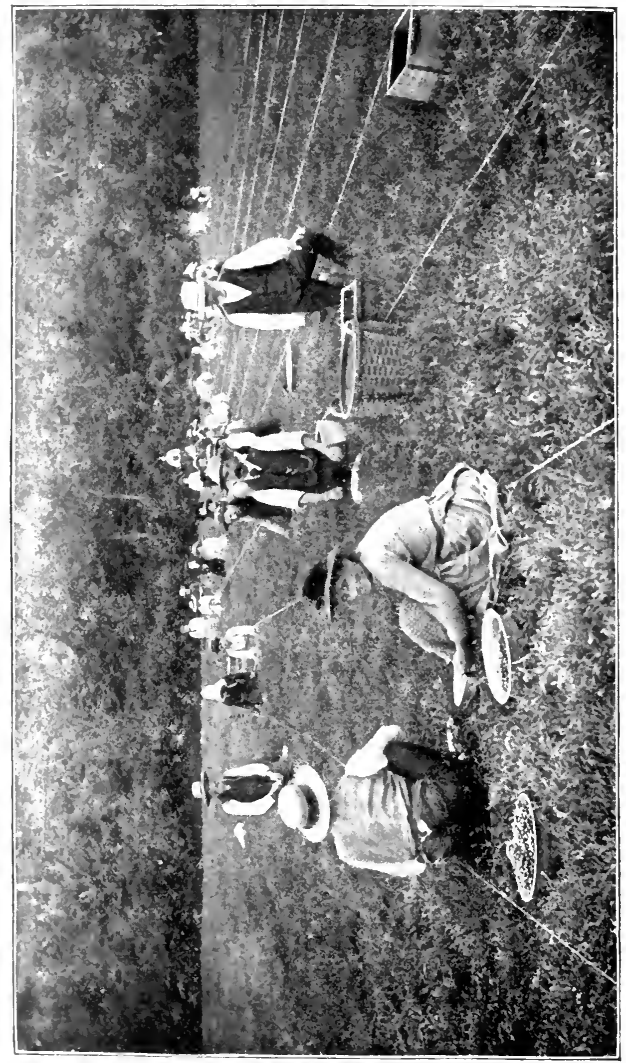

ב 
not be wandering over the plantation in search of the best picking. Fig. 90 shows the method of "lining off" cranberry pickers.

Necessity of hand-picking.-It would seem to be unnecessary to say that all fruits which are to be put into a good market should be hand-picked, and ret it is a fact that a great quantity of the apples, and even of the pears and plums, which go into our common markets are shaken from the trees. It is impracticable to grade or sort such fruits, because the proportion of jammed or bruised fruits is so great that the samples of first quality are found to be very few. It is an axiom in fruitmarketing that only the best fruit pays for eareful packing, and that the poor fruit is rarely worth the trouble of grading. The better the frnit, therefore, and the more carefully it is picked, the more profitable may be the attention which is given to sorting and packing.

THE PACKING OF FRUIT.

What is first-class fruit?-The very first thing to be considered in the packing of fruit is to determine what first-class fruit is. Even amongst those persons who sell apples for the export trade, there is very little exact practice in the sorting of the apples. It seems to be ordinarily considered that any fruit which is sound enough to reach its destination is good enough to be called first-class; but such standard is a serious error. The fruit 


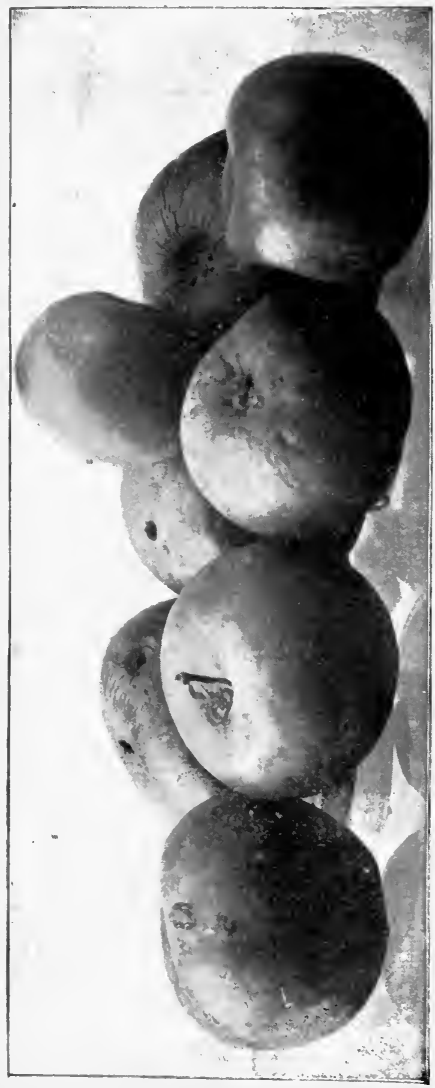

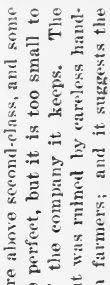

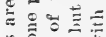

$\approx \stackrel{\bar{c}}{=} \mathrm{s}$

है

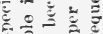

言: 气

클

च क

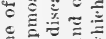

हैं ڤิ

$九 \stackrel{2}{2}$

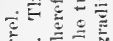

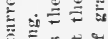

$\underline{\Xi \pm ⿻}$

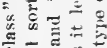

递

$\frac{1}{4} \stackrel{0}{=} \cong$

\&

ธ 대월

क ष

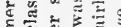

है

ह

c

ह ․ㅝ

ह

ह है है

홀

ज ह

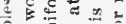

ड ह

일

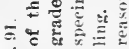
si i 
should not only reach its destination in approximately the same condition in which it leaves the orchard, but it should also be attractive and uniform in quality, and capable of being held for some time when it reaches the wholesaler. Mere soundness or perfectness of form and freedom from all bruises and blemishes do not constitute a first-class apple. All the specimens should grade up to a more or less uniform standard of size and shape, and any fruit which is ever so perfect in itseli would not be considered to be first-class amongst fruits which average either very much larger or very much smaller. In other words, there is a great difference between a perfect specimen and a firstelass parcel. Perhaps it will answer all requirements to define first-class fruit as a quantity of sufficient amount to be quoted in the market (as one box, basket or barrel), which is thoroughly well packed and of one variety, and in which the individual specimens are very nearly uniform in size, shape and degree of ripeness, are possessed of fulllength stems (in stem-bearing fruits), are free from bruises and injuries and all insect and fungous blemishes, are fully characteristic of the variety, and are in that stage of maturity which the market demands at the time of their exposure for sale.

This is well illustrated in Fig. 91, which represents a tray of winter apples. It shows a variety of apples of second and third class, and yet they were taken from a lot which sold for first-class fruit. It may be well to designate the particular points in 
these apples which throw them ont of a first-celass simple. Beginning with the frout row, the spereimen upen the left is seablesel in two or three places; the mext one has a worm-hole about the stem, but it is otherwise perfect; the thind one has a worn-hole in the top, and is also shrivalled; the end one on the right was a perfect apple as it homg on the treer, hut when shaken off it struck a limb or the gromud, and

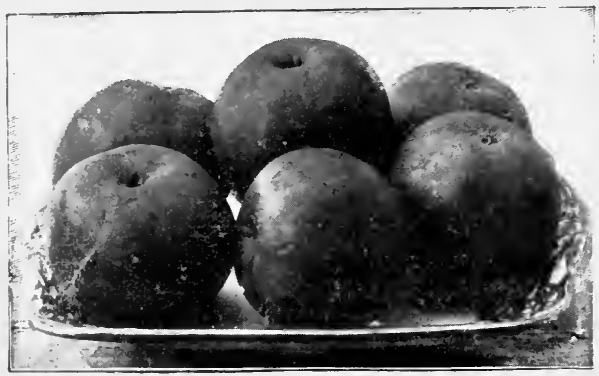

Fig. 92. First-elass sample.

was flattened on one side. Begimning with the left splole upon the lark row, it will be seen that there is a had inseret blemish mpon the side; the secoma one has a puneture in the side; the third one, on top), is perfort in itself (as a specimen), but it is of very inferior size for apples of its olass; the last apple upon the right has a worm-hole in the blossom end, and is withereal. Fig. 92 shows a filstrlass sample. Fig. 93 (page 408) slows a barrel of 
Ben Davis apples just opened, in which the different specimens are of uniform size and quality.

Essentially these same remarks may be applied to other kinds of fruits. It should be remembered that the more personal and local the market, the more exacting that market is, and therefore the greater attention should be paid to the details of sorting and grading. It should be especially impressed upon the horticulturist that uniformity in size is quite as important to a package of fruits as excellence in intrinsic quality of the individual speeimens. The reader will also recall that the proper grading of fruit is greatly facilitated by thinning the fruits on the trees, a subject which has received speeific treatment in Chapter VI. It would seem to be unnecessary to add that the mechanical sorters now recommended in some quarters are wholly unadapted to use for any but the rougher and cheaper qualities of fruits and for potatoes. High quality apples which come through the sorter apparently without blemish usually show discolored spots in a few days, and softer fruits are often ruined.

It is evident, therefore, that if fruit is sorted, two grades will result, - the first-class grade and the remainder. In small-fruits, these two grades-known as the firsts and the seconds-usually comprise the entire crop, and the same may be true of tree fruits which have been well grown and rigorously thinned. In most cases, however, tree fruits are made into three grades, the third grade being generally known as culls. Persons who sort their fruit as carefully 
as our definition requines will do well to designate the first grate by some speecial name or mark, as "siclected," "First (hoiece," and the like, in order to distinguish it foom the eommon type of so-called first-elass fruit. In such thorough sorting, four grates are often necessary, in order to properly present the frout to the various types of consumers. It shonlel be remarked, however, that the better the fruit as it hangs on the tree or vine, the fewer will be the grades in the parking-honse.

The parking of fruit, therefore, comprises two rather distinet elements, - the sorting or grading (which has now been ronsidered), and the plaring of the fruits in the final receptacles, or packing proper, to which we now proceed.

How to preck.-The method of packing must depend very greatly upon the market which is to be reached, upon the quality of the fruit, and upon the parkage which is to be nsed. Ordinarily, women are better fruit-packers than men, especially for the delirate fruits, like peaches, the berries and grapes. Each individual fruit or clnster should be placed in the parkage separately and by hand. This is emphatically true of all the tender and perishable dessert finits. The specimens are ordinarily laid in conrentrie rows, the first row being placed on the ontsicle of the bottom of the basket, and other cirrles filling in the layer until it is full. Other tiers are then placed in the same way. The top layer is placed with special care, the stems of the fruits being all laid one way, and the same side of the 
fruit (ordinarily the cheek) showing uppermost. The top of the basket should present a uniform and finished appearance, and should be slightly rounding or oval in shape. There will ordinarily be a difference of from five to ten cents a basket between good plums or peaches sent to the market as they are picked from the tree, and those which are properly packed and finished up.

When packing apples and pears in kegs or barrels, it is not always necessary to place every individual; and yet, if the packages are to go abroad, it is ordinarily best to take this pains, laying all the fruits in tiers, for thereby there is tight packing and little shrinkage; and when one handles his fruit so carefully he is constantly throwing out the inferior samples. As apples are ordinarily handled for our domestic trade, however, they are simply faced upon the two ends. They ought always to be faced upon one end. This facing is done by selecting apples of uniform grade and placing them in concentric rows on the lower head or end of the barrel. Abont two or three tiers should be faced, the rings of one tier breaking joints with those of another. The stem end should point towards the head of the barrel. The apples in the middle of the barrel may be turned in from a round-bottomed, swing-handled basket, which ean be let directly into the barrel (or from a smaller basket which will turn in the barrel), and after every basket is emptied the barrel should be lightly shaken to settle the fruits. It is generally advisable to face the upper 
head of the barrel before the head is plated in, but this is not always dome. The barrel is ordinarily headed up, then ended over, and the oplowsite or originally-fated end is stenciled, and this is the and which the dealer is supposed to open. It

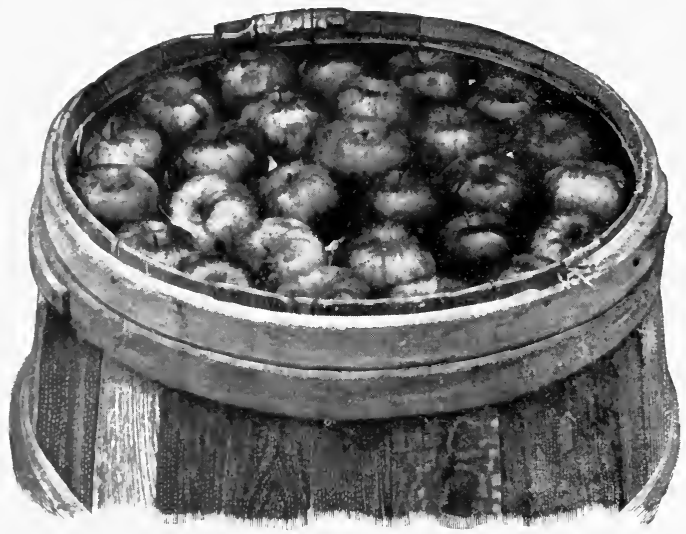

Fig. 93. Barrel of first-class apples opened up in the market.

very frequently happens, however, that the dealer, in order to test the packing, opens the wrong or mintended end of the barrel: and in selling large lots of apples two or three barrels are sometimes nsed as samples, and the entire contents are rolled out upon the parking house or anction room floor. 
A barrel of winter apples properly faced and packed is shown just as it was opened in Fig. 93.

The greatest care should be taken in the packing of apples for export, because they are subjected to long and trying transportation, the freight and incidental rates are high, and only the very best fruits will pay transportation and other expenses. One reason why the foreign market has recently been so poor for American apples is because a great amount of poorly-sorted and poorly-packed fruit has been exported. The following suggestions for the exporting of apples are condensed from a report made by George T. Powell, of New York state, to the Commissioner of Agriculture for that state, and will be found to be very useful :*

"Kind of fruit wanted.-Only good fruit is wanted abroad. The fruit-grower should begin months in advance to secure good quality, by practicing good tillage, efficient fertilizing, and thorough spraying. Apples grown on trees which have imperfect (insect-eaten and fungous-infested) foliage generally fail to earry in good condition to Europe. Standard fall and winter varieties are most in demand in the export trade. Duchess and Twenty Onnee generally sell well if pieked while hard. Alexander is too soft. Baldwin, Greening, Spy, King, Spitzenburgh, Hubbardston (Nonesuch), Newtown (Pippin), Peck's Plęasant, and late Russets are popular varieties. Jonathan and other medium-sized apples are especially desired. Red apples sell better than solid green ones, as a rule. Soft summer varieties do not ship well.

"Picking the fruit.-Apples intended for export should be picked earlier than for the home trade, but not when green

* Suggestions as to the Picking and Packing of Fruit for the Foreign and Home Markets, Albany, 1896. 
and immature. It is largely the beauty of the American apple which sells it; therefore, the eolor should be well advalued before the apple is pieked. Hand piek the finest very carefully. It is advisable to harrel and ship as soon as jirkked, rather than to store the fruit for some days in piles in the orehard.

"Parking.-Fort earefnlly. Very fine fruit should be marked 'Fancy' or 'Selected,' with four $\mathrm{X}$ 's (XXXX), and with the grower's or shipper's name or initials. The second grade shoukl be good, and marked with three $\mathrm{X}$ 's. Nothing lower than this should be exported. The English law requires that the package he phinly marked 'American Produee.' Lse only stamlarel size barrels. Put in a double row of facers. Apples somewhat soft in texture, like Greenings, may be pressed down a full inch in larreling, but hard apples should not be squenzed so much. Ninil the barrels securely. If the apples beome loose in transit, they will be very much injured.

"Methork of sile.-Apples are solel in the English markets hy sample. Two barrels of a lot are selected, one opened to show the packing, the other turned out so that every apple can he seen. The lot is then sold at anction. The first lay of sale they are solel as 'soumd.' These are delivered within twenty-four hours. Any loose barrels, known as 'slacks' or 'slaek packed,' and any from whieh the juice is ruming, called 'wets,' are closed ont at the snceeeding sale."

Shiftless packing really accounts for more than one-half of all the unsatisfactory returns from fruit. This fact is commonly acknowledged to be tine by the fruit-growers themselves, and it is ammally impressed upon them hy teachers, buyers and consumers, and yet it is an astonishing fact that the great majority of all our fruits are either not packed and graded at all, or else the work is done in the most eareless manner. The eastern fruits are often better in quality than the Californian fruits, and 
being grown near the consumer, they ought to command a superior price; and yet it is a fact that because of the better packing and sorting of the California product, it drives the home fruit from the markets. The better packing of this Californian product has arisen from the fact that transportation rates are such an important item in the marketing of the fruits, and time of transit is so long, that only the highest-priced and soundest fruit can bring the consignor any profit after the expenses and risks are doducted. It is always found that the farther fruit has to be shipped, the greater is the care exercised in the grading and packing.

Whilst we, with the best of reasons, are constantly deploring the shiftless attention given to the packing of our fruit, the fruit-growers of Europe are impressed with the excellent condition in which our apples often arrive in their markets. The following extract is from a German paper of recent date :*

"Although during the last few years repeated attention has been called, by those in authority, to the development of the German fruit industry as a possible means of enlarging the net proceeds of domestic agriculture, it is necessary again and again to recur to the subject, and especially at this time to eall attention to the fact that our fruit industry is confronted by a crisis which, if it does not meet with immediate and strong resistance, threatens to completely destroy it, and thus to greatly damage our national welfare.

\footnotetext{
*Deutsche Tandwirtschaftliche Presse, xxiv., No. 7, Jan. 27, 1897.
} 
This danger has now beeome artual through the floesling of the German market with fresh American apples. It is, e. y., a fart, that during this winter the demand for apples in Berlin is being supplied with the Aneritean product, and others are scareely offered or not desired. This condition, and the dangers to the ferman fruit industry arising therefrom, are set forth in a praiseworthy mammer in a small pamphlet by B. L. Kühne-Rixdort (Berlin, 1897). This pamphlet also points ont the means by which we in Germany, by following to some extent the practical American-in relation to the growing of a. few good marketable varieties of fruits, rigidly sorting them, and parking and shipping in proper paekages-can sueressfully meet the dangers alluded to.

"The suggestions made by the anthor of the pamphlot are as follows:

"1. The fast transportation of fresh German fruit at low rates on the part of the railroads.

“.2. The cultivation of a few valnable varieties.

"3. The rigid sorting of fruit destined to be eaten in the fresh state.

"4. The rational conversion of the less valuable fruit into imperishable narketable produets, as fruit juires, eider, marmalade, jelly, steamed fruit, dried frnit, and fruit wines.

"5. The general introduction of light, cheap and strong packing eases of standard size.

"6. The proper packing of the fresh fruit.

$" 7$. The training of scientifie and praetieal speeialists in fruit "ulture. 
"8. The planting of large, rationally conceived and intensively eultivated fruit plantations, for the immediate supply of the German market.

"The present conditions prove that past methods for adrancing the German fruit industry have not been productive of the desired results, and it is high time that all who have the welfare of this industry at heart unite on the basis suggested; then and not until then will the conditions improve through the increased home production of fruit, if but sufficient to cover home consumption; we shall be able to successfully meet foreign competition, and this done, it will be possible to conquer for the German product a prominent place in the markets of the world."

Fruits which are intended for the dessert may often be put into the consumer's hands in very excellent condition by wrapping them in soft grocer's paper, of the kind which is ordinarily called tea paper; or, when the product is especially choice, and the grower has a large quantity, it may pay him to use a grade of tissue paper. There are many middlemen who practice this careful packing, and growers may often imitate them with profit. It is needless to say that all wrapped samples of fruit reach the consumer in perfect condition, and he may depend upon their excellence and uniformity as he could upon a case of eggs. With pears or apples, the inside of the keg or barrel is lined with newspapers, and each fruit is individually wrapped in soft manilla paper. Such fruits may be expected to carry thousands of miles without perceptible injury. When 
opened, their aroma is such that no well-bred eonsuncer can resist the temptation of a high price. Ordinary fruits, howerer, are not worth this care.

It is important that all fruit should be packed very smug, especially that which is to be shipped any distane in barrels or other large parkages. Fruit whirh is slack when it reaches the market is nearly always injured, and sells as seeond or third quality produrt. This slarking or shaking in barrels may he prevented by using fruits which are not over ripe, by areful attention to grading, so that all the spereimens are of miform maturity, by keeping the product eool after it is pateked, and especially by plaring the fruits in the parkage by hand. Barrels of apples and pears should ordinarily be filled about an inch above the rhine and the frout should be pressed in with a sorew or lever press until the head eomes into place. If the fruits are wrapped in paper. or if the parkage is lined with sereral thicknesses of paper. the spring of the paper itself will take up the slark and will keep the fruit in place; and in surh cases it is not necessary to apply heary pressure in the heading-np of the barrel.

Epon the best brand: of fruit, a trade-mark is often important. Some neat pietorial design, with the name of the grower and a statement to the efferet that the fruit is guarinteed to be as represented, attracts the ere of the purehaser and gives hom eonfidence in the article; but to put a trademark upon fruit of indifferent or even of ordinary quility is little more than a joke. If a man uses 
a trade-mark, he must expect, of course, to handle his own produce, or at least to see that it reaches the market under his own name. The fruit buyers who travel through the country for apples and other produce ordinarily pay little attention to the trademark of the grower, but put their own mark upon the package. If one really grows a good quality of fruit, it will commonly pay him to give his farm some neat and attractive name, which can go onto the labels. In short, every effort should be made to put up the produce in a finished manner, as the best grades of manufactured produce are now packed and delivered to the consumer.

Very much of the success of any fruit upon the market depends npon how it is grown as well as how it is handled. There may even be a difference in the salableness of samples of fruit which are to all appearances alike. It is now pretty well demonstrated, for example, that apples from trees which have been thoroughly sprayed and well tilled are better keepers than those of similar size and appearance which are grown upon neglected trees. When fruits are to be shipped to any distance, it is particularly important that the tillage and general care of the fruit plantation should have been the best.

Packages.-It is well nigh useless to make any general remarks upon the packages which are used for fruits, because so much depends upon the particular grade of the fruit and upon the way in which it is shipped and handled; very much also depends upon the demands of the given market. 
It is an excellent plan for the fruit-grower to visit markets in advance of the ripening of his crop, and to determine just what style of package his market will most appreciate. When fruits are pooled, or shipped through exchanges or unions, it is imperative that a miform style of package should be used: but when a man handles fruit solely npon his own account, and has a fine or superior quality, he ean. often advertise his product by a unique parkalge, or at least by one that is mulike those in most rommon use. Such a package singles him ont from his neighbors, and answer's as a trade-mark for his product. The writer has known profitable retums to be got from fruit which was shipped in rolored baskets. A dye was made of aniline, and the haskets were dipped into the kettle (being handled with a pitchfork), and fruit which was no better than the ordinary rum bronght from two to five cents a lasket more than that paeked in the ordinary white package. This will not often sneceed, however, but this instanee is given simply to show that a poekage which is somewhat out of the usual ron may be a desirable one for a man to use upon particular ocasions.

In all the finest fruits the grower should use nothing but a gift parkage, that is, one which is given away with the fruit when it is sold. This insmes a clean and dainty parkage, and the purhaser is not bothered with the thonght of retmrning it. In fruits which are to rearh a goos market. a paekage which has been used once is a positive 
detriment. In very many cases, it is the packing and the package which sells the fruit, more than the fruit itself. When fruits are sold by the definite quantity, as by the quart, the peck or the bushel, the packages should be full measure. It sometimes happens that for a time a man secures as much for a short or snide package as for one of full measure; but such a person can scareely expect to hold a superior trade for a great length of time.

The most popular package at the present time for grapes, peaches and apricots is the Climax basket, which is made in varions styles and sizes. Some of the common forms are shown in Fig. 95. These are made in sizes holding from five to ten or twelve pounds of fruit. They are handy, cheap, nest well in the shipment, and are durable. A good basket of any kind should be one which is neatly made, with no splinters or tag ends hanging from it, which is firm and symmetrical in shape, well nailed, and which is perfectly clean or white in appearance. Baskets become yellow and discolored if they are left in the sun; therefore, when they are stored, they should be placed in a clean and dark dry loft or room. If packages which have been left over from the last year are somewhat dingy, it is sometimes possible to bleach them by burning a little sulfur in the room.

The grower, then, will begin some months in advance to look up the packages which he shall use, for he will thereby not only suit himself and 


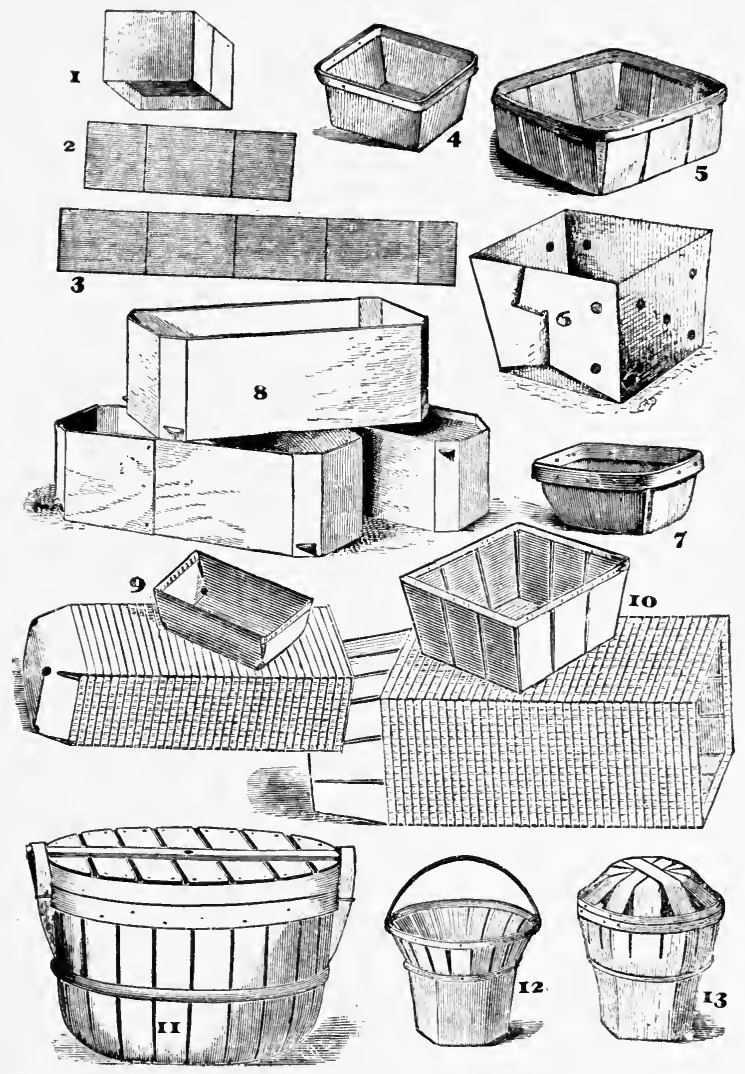

Fig. 94. Various types of fruit packages. 

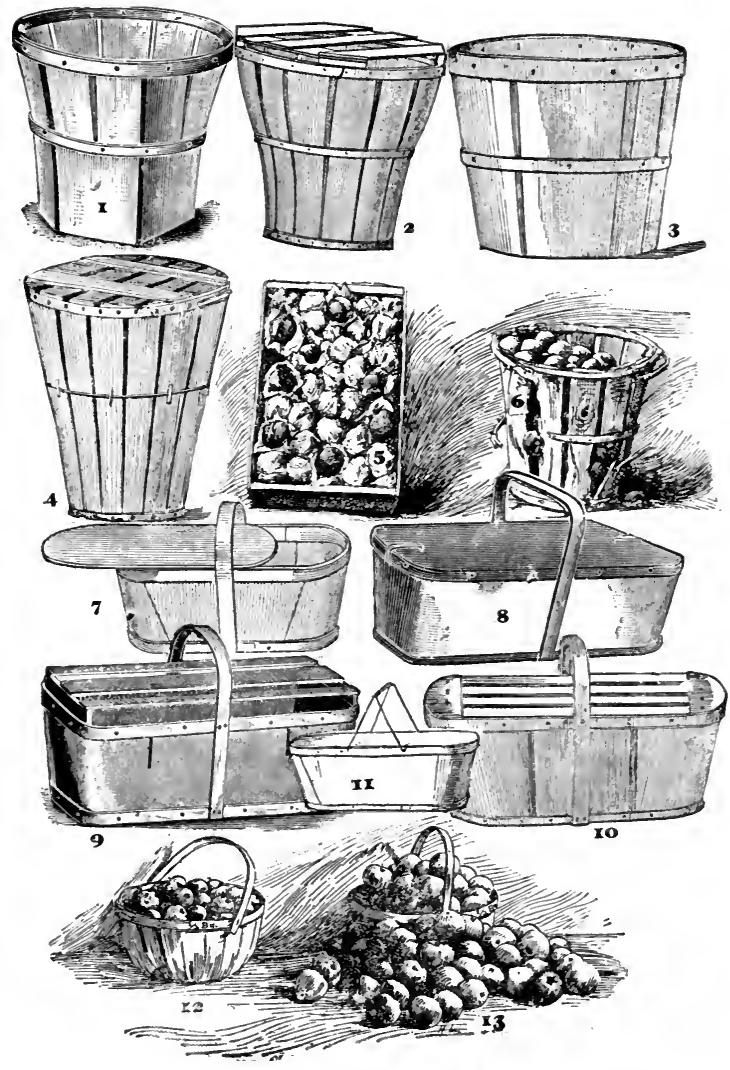

-Fig. 95. Various types of baskets. 
the market, but he will likely be able to secmre his packages at a lower cost if he gots them early in the season; and he will, in any event, he sure of his packages in ease there shonld be a large demand for them at marketing time. It is well to secme the illustrated priee-lists of the mannfacturers, and to thomonghly canvas the subjects of styles and prices some months in adrance.

All packages smaller than a half peck should be shipped in erates. It is onstomary to nse crates with slat sides and an abundance of openings, in order to insure complete ventilation; but if the fruits are firm and dry when they are pieked, and are then reduced to a lower temperature, they can be shipped in unventilated erates, generally with better results (page 397). The shriveling and shrinkage of the fruits will be less in the tight erates, and decay will ordinarily be less also. These crates should be gift parkages, and made out of light split stuff, as bas-

Note.-The pictures in Figs. 94-97, pages 41\%, 419, 422, 423, are shown for the purpose of acquainting the reader with some of the leading types of fruit packages now in use.

Fig. 94,-No. 1, common quart berry box; 2, the bottom, in flat: 3 , the sides, in flat; $4,5,7$, till baskets ; 6 , paper basket, set up; 8 , ollong quart boxes; 9, 10, metal-topped baskets; 11, bushel basket with slat eover ; 12, common splint peach basket; 13, same, with cover.

Fig. 9.5.-No. 1, veneer peach basket; 2, standard peach basket; 3 , veneer straight-sided basket; 4, vegetable basket; 5 , California peaches, wrapped in paper; 6, a frequent result in the market; $\tau-11$, varions styles of ('limax baskets; 12, 13, baskets for apple-picking (same number of apples in each, but those in 13 from sprayed trees, those in 12 from untreated trees).

Fig. 96.-No. 1, Diamond market basket ; 2, 16-pint basket-tray ; 3-9, vari. ous styles of erates for berry boxes.

Fig. 97.-No. 1, crate for Leslie boxes: 2, 4-quart hand-tray ; 3, 24-quart erate ; 4 , till-basket crate ; 5 , 6 , fruit boxes (holding from $1 / 2$ to 1 bus.); 7 , 
kets are. Crates which are designed to be returned to the grower are usually heary, are commonly made of sawed stuff, and are provided with hinges and clasps. In shipping long distances by rail, large crates (holding as many as sixty baskets or eups) are generally preferable, because there is less "side shake," because of the greater bulk; and such heavy packages are not so carelessly handled as the small ones are. The time is rapidly coming when all the better grades and better qualities of fruits will be put up in special gift packages, and the time cannot be far distant when pasteboard boxes will be used to some extent. One of the most marked results of the recent advancement and competition in the manufacture of products is the packing of single articles in tasty boxes. Boots and shoes, for example, were shipped loose in large cases a few years ago, whilst now, in all of the better grades, every pair is boxed by itself. In other words, not only is the product itself a finished article, but it is packed in a dainty and finished way, and the same

The bushel box; 8. patent fruit barrel; 9. Higheliffe patent barrel for export apples (arranged to be sawn in two withont distubing the fruit.

With these packages the reader should compare Fig. 98, showing erates actually sent into the New York market with pears. The grower was evidently of an economieal turn of mind, for he had made the packages of the odds and ends of the place,-old boards and old rail, a wagon-jaek, and a wagon-reach! The New York party who sent us these packages wrote as follows: "I fonnd a new fruit package on the market here, and as I know that you are deeply interested in hortienlture, this will be of interest to you. It was invented and manufactured by a man up the Hudson River, and was used for shipjing pears. The commission man who received this package offered it, pears and all, for $25 \mathrm{cts}$, but could not sell. I requested him to empty the fruit into a $\mathrm{keg}$ and let me have the package. He did so, sorting out a few of the smallest fruits, and then sold the keg for $\$ 1 . "$ 


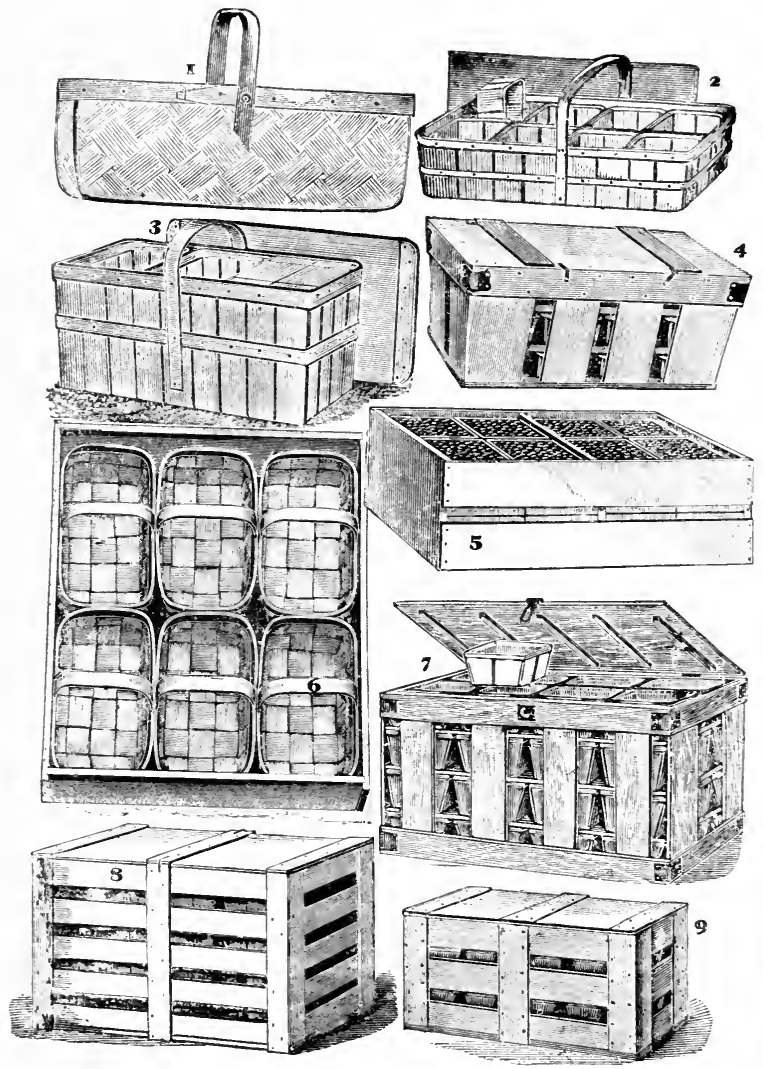

Fig. 96. Baskets and crates. 
numst come to be true of many of the better kinds of agricultural products.

In the fanciest fruits, like the best dessert pears, and even some of the largest and finest strawberries, it is often profitable to ship in cases something like

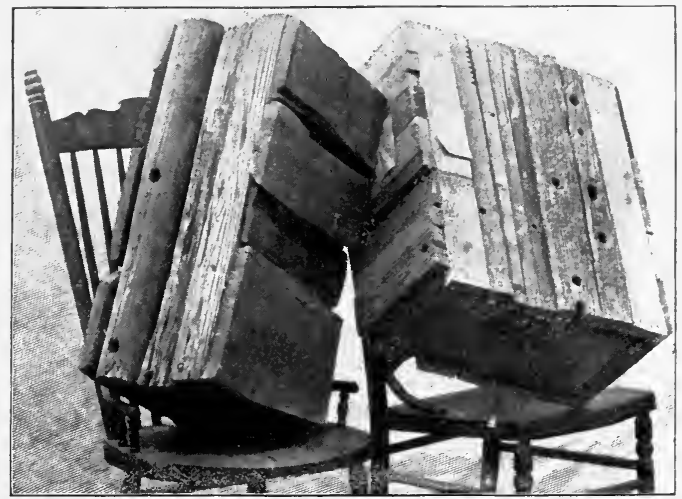

Fig. 98. Novel packages found in the New York market.

those used for eggs, in which each individual fruit has a compartment or receptacle of its own. If, in addition, the fruit is carefully wrapped in these compartments, the very finest type of packing will result. To one who has not followed the market elosely, all these suggestions will seem to be expensive and nnprofitable; and this is certainly true of everything 
but the best quality of fruits. The common run of goods will not bear the expense of extra care in the handling and marketing, and this is the kind of fruit which it does not pay to grow. If one makes a study of the market he will soon come to feel that the package and the packing eut a most important figure in the sales. The package really advertises the fruit more than the fruit advertises itself; and it is a well-known business principle that an article which is first-class will stand very heavy advertising, but no other will.

\section{PACKING-HOUSES AND APPLIANCES.}

The subject of packing-houses is one which cannot be treated specifically for each grower, from the fact that every person has a different ideal, and he may grow fruits for a market which demands particular treatment of the products. Amongst the best types of packing-houses, which one generally meets in the east, are those used by the grape men; and if one studies the question, he will find that there are two distinct types of packing-houses in use in the grape regions. One type is a combined packing and storage house, and is used very largely where Catawbas are grown, and where the grapes are often stored for some time before they are marketed. The other type of house is that which is used in the Concord regions, and which is simply a half-way station between the field and the railway station, - a shelter place for the pack- 
ing of the grapes,-and is not used for the storage of the fruit.

One of the best of the storage type of parkinghouses (used for holding the fruit until winter or later) may be described as follows: ${ }^{*}$ It is built on a side hill, and the basement or cellar is used for the storage of grapes, the first floor is used for parking, and the second floor or attic for the storage of baskets, crates, and the like. This building measures $25 \times 60$ feet over all. The foundation walls are 24 inches thick, and the cellar is provided with ample means of rentilation by ontside windows, and also by means of a chimney which rms from near the middle of the cellar up through the roof. The floor is of dirt. By means of eareful attention to ventilation, this cellar ean be kept to $50^{\circ}$ or below during September and Oetober, and is frost-proof during the winter. The windows are provided with close-fitting sereens, to keep ont rats and squirrels. This cellar will hold easily fifty tons of grapes in the picking trays. The first floor is divided into two rooms, the front one being a parking-room 25 feet square, and the baek room being a storage and shipping department $25 \times 35$ fret. This packing-room is provided with heat, and is lighted by seven large windows. The floor above the cellar is double and made of $1 \frac{1}{4}$-inch matrhed pine, with an abundant air space between the two layers. This, therefore, proterts the cellar from

*Bull. 117, Cornell Exp. Sta. 
sudden fluctuations of temperature. The building is also shaded, especially from the afternoon sun, by large trees. This building can be erected for about

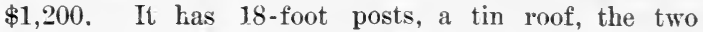

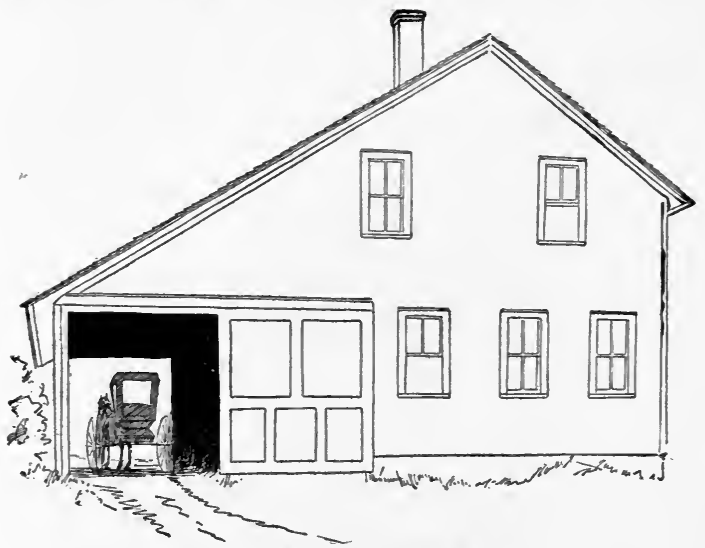

Fig. 99. A good type of packing-house.

rooms in the first floor ceiled with pine, but the top floor not ceiled.

The other type of packing-house (used only for purposes of packing and of storing packages) is admirably illustrated by Figs. 99 and 100, which are pictures of the house of W. W. Pettit, Brocton, New York. In this case there is no cellar, for the grapes are not to remain in the house more than a day or two at the longest, and they ordinarily 
pass directly through it on their way to the railway station. This is a honse which can be built for abont $\$ 500$. The main floor of the building is $24 \times 40$ feet, and aside from this there is a driveway, $W^{\prime}$, moder the same roof, and whith measures

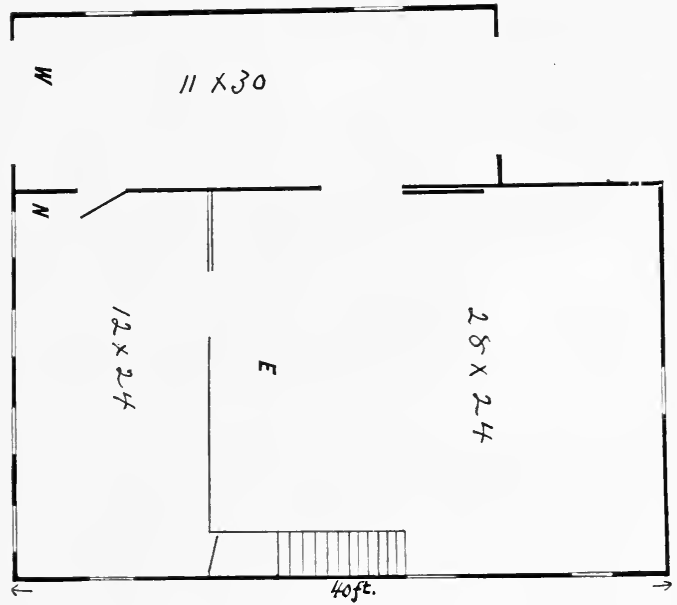

Fig. 100. Plan of the $40 \mathrm{ft}$, packing-house.

$11 \times 30$ feet. This driveway conneets with the main floor by two doors. The front room, $\lambda$, which is lighted by four windows in the front and one upon the side, and is $12 \times 24$ feet in size, is the parkingroom. In the rear of this is a store-room, $E$, for the grapes. The half-story above is used for baskets 
and erates, and these are delivered into the packing-room by a shute. This building will accommo-

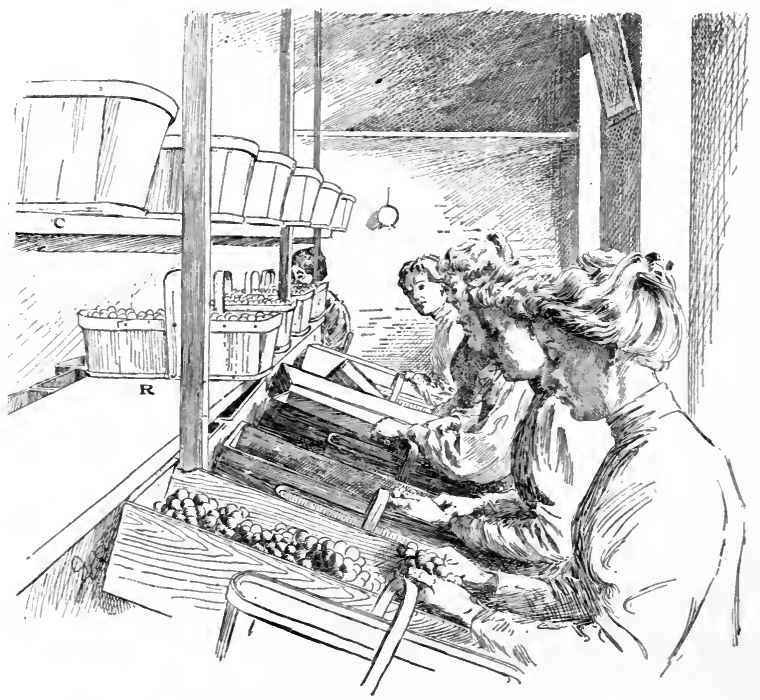

Fig. 101. The packing and sorting of grapes.

date ten packers, and will easily handle the grapes from fifty acres of land.

In the packing of grapes, the greatest care is required to keep the fruit clean and fresh, to prevent the bunches from being broken, and to preserve the bloom upon the fruit. It is essential 
that the home should be kept thoromghly clean and sweet at all times. It is esperially important that the storage room for the baskets and crates should be dry and airy, in order that the baskets may

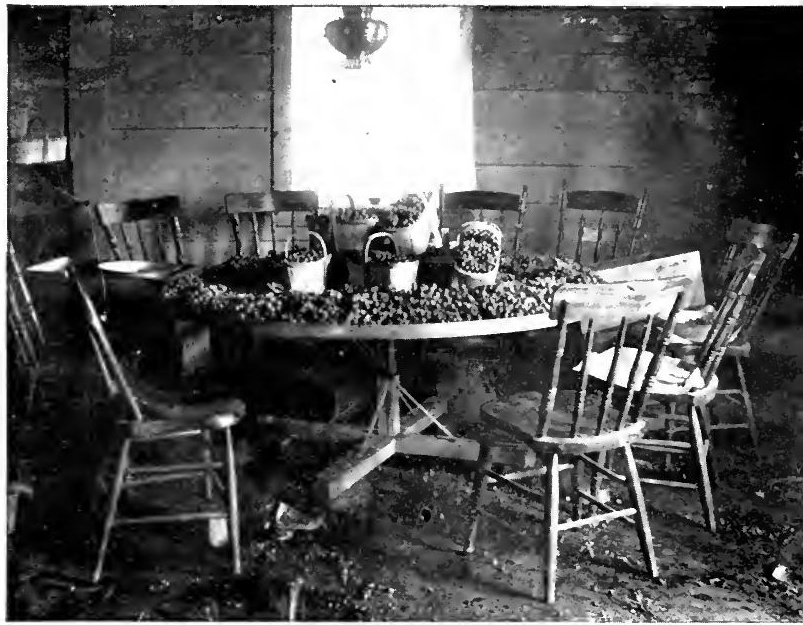

Fig. 102. Revolving packing-table of the Kenka grape region, New Vork

not beeome moldr or mustry and this room should also be kept darkened, to prevent the baskets from roloring.

In Fig. 101 is shown the parking room in Mr. Pettit's house. In this case, the pioking trays are set before the packers upon an inclined table, and the 
packer handles the grapes from this tray into a basket which she places at her left. When the bassket is filled, it is placed upon a flat ledge in front of her ( $R)$, and is taken off by an attendant, who places the baskets on a truck and rolls them into the back room, from which they are delivered to the wagon. Empty baskets are stored upon the high shelf $\mathrm{C}$, and these are replenished by an atten-

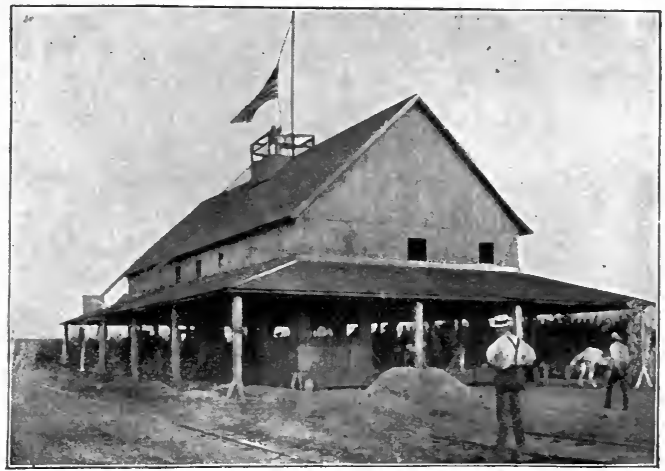

Fig. 103. Packing house of the Hale orehards, Georgia.

dant, as necessary. When the tray is empty, it is slid throngh an opening just in front of the packer and underneath the flat ledge upon which she places her finished baskets. Fig. 102 shows a packing-table in the packing-room of George C. Snow, Penn Yan, New York. This is a circular revolving table, about 
which the packers sit. The packer holds the basket in her lap and takes the grapes off the table, which is turned as fresh fruit is put upon it. This device allows the packer to select from a large quantity of fruit.

The packing-house of the great Hale orchards in Georgia is shown in Fig. 103, and an interior view

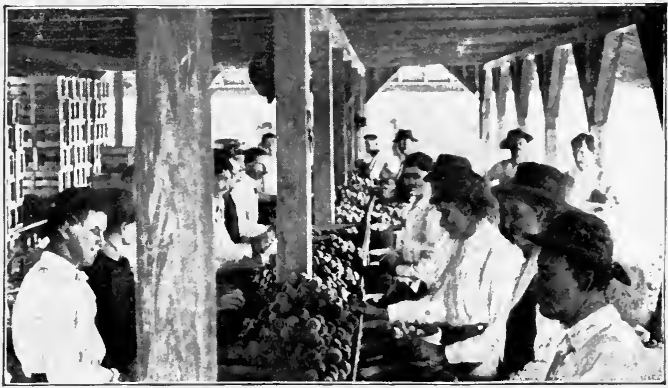

Fig. 101. Packing peaches in Georgia.

in Fig. 104. The latter picture is a peach-packing scene.

The suggestions in the last few pages eover most of the points which it is necessary to eonsider in the construction of a packing-house. The grower will be able to apply them to his own conditions. A simple temporary shed ereeted in the orehard is often made to serve all the purposes of a parkinghouse. A cloth tent is often used. The appliances 
which are needed in packing-houses, aside from packages and crates, are trucks, sorting-tables, barrel presses, and an abundance of baskets or barrels for the refuse fruit.

Sorting-tables are of various patterns, but those which are used for apples, cranberries (Fig. 105),

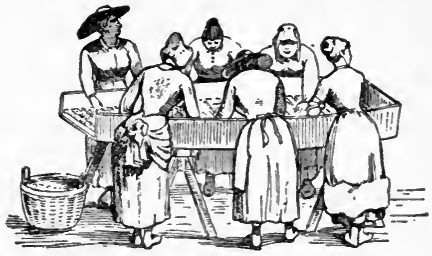

Fig. 105. Sorting cranberries. and other firm fruits, consist of a table or tray about twice as long as broad, narrowed at one end, at which it is open to allow the good fruit to roll off into a basket or barrel. The fruits are poured from the picking baskets on to the table, and a number of persons standing on either side remove the litter and the inferior fruit, whilst they work the good fruit on to the ontlet.

Of barrel presses there are several styles. The most expeditions is some kind of lever press (like No. 3 in Fig. 106), but more pressure can be obtained with a serew press ( 7 ), and such an implement holds itself in place whilst the head is being adjusted. Fig 106 (on page 434) contains illustrations of all the types of barrel presses which are in common use. They are: 1, home-made lever press; 2, Climax lever press; 3 , improved lever press; 4, stand-up barrel header; 5, packing press (for packing and baling goods); 6, stirrup press; 7, iron screw press. 


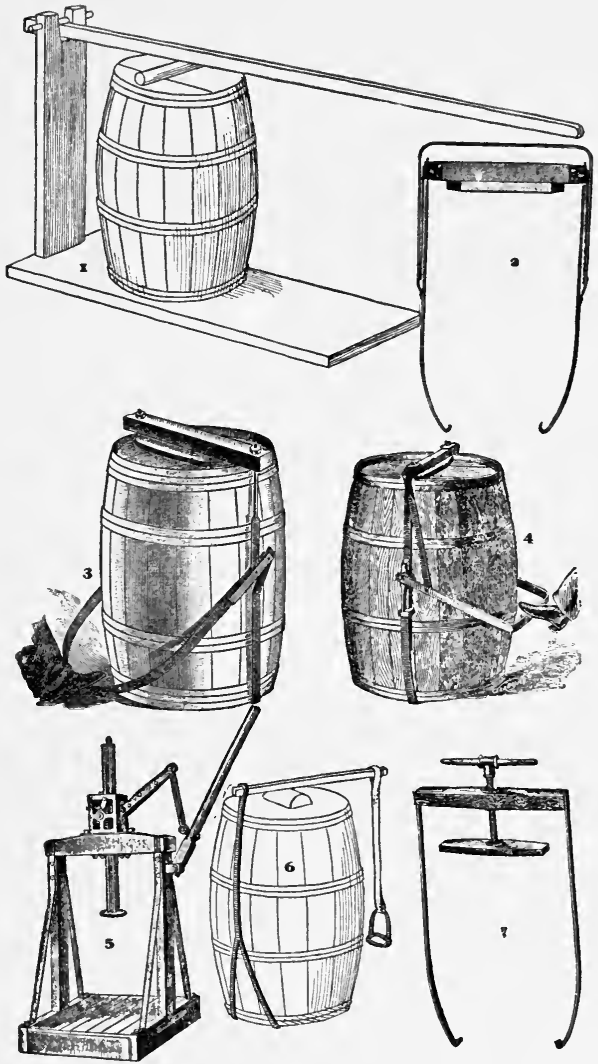

Fig. 106. Barrel presses. (See page 433.) 


\section{STORING FRUITS.}

It is impossible to draw the line between a packing-house and a storage-house. In fact, the same structure may be used for both purposes, as the grape house is which has been described in the preceding pages. There is more and more necessity that the fruit-grower should provide the means of storing fruits, when prices are low and competition is very sharp.

General advice.-As a rule, it will not pay the fruit-grower to build iced storage or chemical storehouses for his fruit, unless he has a very large acreage. This cold-storage of fruit is really a business by itself, and requires a great deal of care and skill to carry it through successfully, and a discussion of it is foreign to the purpose of this book. If the grower desires to keep his produce until late winter or spring, and has no cellars or natural storage place, it will ordinarily pay him best to put it into some commercial cold-storage house, and to pay so much per package for the storing of it.

For temporary storage, however, these remarks will not apply. Every person who grows fruits, especially perishable kinds, should have some kind of a building in which he may place the fruits over night, or for two or three days, when waiting for the market to improve, or for the purpose of cooling them down before shipment. These houses are ordinarily cooled merely by cold air. They are often 
known as "chill rooms." A room which is well fitted for the keeping of butter in warm weather may also be used to advantage for fruit. In some eases, arrangements can be made for the use of iee to reduce the temperature for the time being. If one has a considerable quantity of fruit, and has a large eellar which is well adapted to the keeping of apples, he ean often store his erop to advantage when the price is low in the fall; but the grower must bear in mind that the risks in the storing of fruit are very great. In the first place, markets may not improve as he thinks they ought; and, again, the fruit may not keep well. Even when the fruit does keep well, there is frequently a large shrinkage, and the expense of re-paeking and handling is a large item. The fruit which is designed to be kept for the late winter or spring trade should be carefully sorted when it is put in storage, and espeeial eare should be taken that none of the fruit is over-ripe. (See page 379.) Fruit which is in proper condition for storing when it is picked may be ruined for long-keeping quality by allowing it to lie in the sun or in a warm place for a day or two.

Neighborhood or coöperative storage is often practicable, without, however, attempting to establish a true cold-storage business. C. H. Perkins* has presented the advantages of such an enterprise to the fruit-growers of New York, as a means of sav-

\footnotetext{
* "Cold Storage for Neighborhoods," Proc. 39th Meeting W. N. Y. Hort. Soc., 41 (1894).
} 
ing the fruit erop over gluts, and especially of holding the market from western competition. This would no doubt prove to be a very useful method for the north for the late fall and winter fruit, but it would probably not be practicable for the south, or for holding the summer fruits. "If, therefore," he writes, "every neighborhood in western New York had a cold-storage house for barreled apples, that would protect against frost and hold anywhere from ten thousand to twenty thousand barrels, run, if need be, on the same coöperative principles and methods as the cheese factories of this state, or the fruit associations of California or Michigan, would not the result be very much more satisfactory to the grower than present methods? * * * * * Such a building may be of moderate cost and yet substantial and durable, and need not always be located at the nearest railroad. How many have ever figured or thought of the cost to the grower of transporting his apples to the railroad or canal station from his farm during the months of September or October, when there is much work to do and time is of most value? Say that the grower is five or eight miles from said station. I believe that for less cost per barrel the dealer located in western New York will deliver the same apples in barrels at Chicago, Milwaukee, Duluth, Philadelphia, New York, or Boston. There are quite a number of apple houses in western New York owned by dealers, but there are few that were built for the express purpose of safely storing apples. I have a building that 
was built for the storage of nursery stock, and in which I have had apples stored all winter. It is frostproof, built on a heavy stone wall twenty-four inches thick and three feet high. On this wall were set up two by four seantling; these were sheathed with inch hemlock, then covered with tarred building paper, then furred out with strips four inches decp, and again covered as before, until the wall has three air spaces. The roof is constructed in the same way to protect against frost. Light and ventilation come from two rows of windows at the top. The roof is gravel. The outside is covered with novelty siding. The building has double or two sets of doors at each end, and a driveway through the center. It is painted inside and out, is one hundred feet long by forty feet wide, the whole cost was $\$ 1,400$, and it would afford storage for ten thousand barrels. The atmosphere is the same inside as out, only that the building is frost-proof and can be rum in the winter montlıs with a variation of not over $12^{\circ}$; there is no smell of a cellar whatever, and stock always keeps perfectly. Such a house, or a better one, in a neighborhood, would pay four years out of five, at least 50 cents per barrel over all cost of labor for handling, sorting, insurance, etc., and this year where there were apples, it would have paid $\$ 1$ to $\$ 1.50$ per barrel."

Requisites for domestic storage.-The home storage establishment is generally either a cellar or a halfcellar, although, by taking particular pains in the construction of air spaces, a building entirely above 
ground may be made to answer the purpose. A building wholly on the surface, however, is more likely to give variable temperatures than one which is partially under ground. An ordinary house cellar, if it has good ventilation and is not too. dry or too warm, may answer very well for the storage of fruit; but it is ordinarily best, both for purposes of storage and for health, that the fruit cellar should be a separate structure if products are to be stored in any quantity. The requisites of a good storage cellar for fruit are chiefly four: protection from frost; the ability to secure a uniform or unvarying temperature of $40^{\circ}$ or below; facilities for ventilation; and air which is moist enough to prevent evaporation.

The protection from frost is secured either by sinking the building below the surface of the soil, or by making two to four air spaces in the walls in that portion which stands above the earth. The ventilation should include facilities for removing the warm and impure air from somewhere near the top of the structure. Some kind of a shaft or chimney construction, with a valve or shutter which can be opened or closed as necessary, will answer this purpose. In buildings which are above ground, it will be often necessary to provide some means of taking in the cold air near the bottom of the building, especially before the cold weather of winter sets in and after the warm weather of spring begins. Cold air being heavier than warm air, it settles upon the surface of the ground in still nights, and if the floor of the storage structure is two or three feet below the top 
of the ground, this cold air may be drained into the building by means of flues which are laid through the walls, the outer ends standing just above the earth. Six-inch sewer pipes, at intervals about the building, answer this purpose admirably. In a building thirty feet wide and seventy feet long, three of these valves along either side, and one upon either eud, are probably sufficient for all ordinary requirements. Sub-ventilation is sometimes recommended, and may often work to good advantage. This is secured by running a long pipe from near the bottom of a cellar storage out to the surface of the ground six or more rods away. This pipe has a valve at the outer end, or at least some protecting structure to prevent the leaves and litter from blowing into it, and it is ordinarily best, also, to have a valve at the inner end. Inasmuch as the earth about this subterranean passage is not frozen during the winter, cold air may be drawn in from the outside and be warmed up above the freezing point in its passage through the tube. This type of ventilation has been used with success in cellars designed for the wintering of bees. It should always be remembered that cold air contains less moisture than warm air does. When very cold air is admitted, therefore, moisture is rapidly taken up when its temperature rises, and the cellar may be made too dry. It is advisable, therefore, to raise the temperature of such air to nearly its ultimate or required degree before it enters the storage room.

Cellars which are very dry cause the fruit to 
shrivel. Those rooms in which there is a natural sand or gravel bottom ordinarily keep fruit in the best condition. Cement bottoms are very apt to be too dry. Running water is very often desirable in a fruit cellar, not only because it furnishes moisture to the air, but also because it is an equalizer of the temperature. One must be cautioned, however, that a cellar which is not properly ventilated will cause the fruit to mold and decay, if it is wet. In general, it is best to have means for supplying fresh air, and then keep the cellar simply moist, not wet. One should avoid drafts in the storage cellar, for currents of air are very likely to cause the fruit to lose moisture and to shrivel.

Much is said about the keeping of fruit upon trays in cellars rather than in barrels or crates, but this must be determined by the character of the cellar as to temperature and moisture. In cellars which are too dry, the fruit should be left in the elosed packages; but if the air is moist and the temperature very low, the fruit may be placed upon racks or trays to the very best advantage. But in any case, it should always be remembered that fruit which has been placed in storage for a month or more, should be re-sorted and re-packed before it is put upon the market. It has been said (page 436) that the best results in the storing of fruit are had when the product is very thoroughly sorted before it is put into the cellar, for even if the cellar is very nearly perfect for the keeping of the fruit, any over-ripe or decayed specimens will very likely break 
down, and spread the contamination to the entire sample. The fruit should be cooled down somewhat before it is placed in cold storage, especially if there is much of it, otherwise it raises the temperature of the compartment.

The requisite features in a domestic iced storage house are set forth as follows by Hexamer:* "To preserve fruit or retard its ripening, it has to be stored in pure, dry, cold air. These conditions can be produced in various ways. But the simplest and least expensive method for farm use is to build a two-story ice house, the ground floor of which is for the storage of fruit and the upper for ice. The most important part of such a house is the proper construction of the dividing floor upon which the.ice rests. The timbers, the size of which depends on the quantity of ice to be supported by them, are so arranged as to have narrow openings between one another to permit the cold air from the ice chamber proper to descend to the storage room below, and also to facilitate the dripping of the water from the melting ice.

"To prevent the water from falling on the fruit, an additional floor or roof has to be constructed nnder the dividing floor. The best material for this purpose is galvanized, corrugated sheet iron, arranged so that all the water which falls upon it flows into a gutter connected with a leader, through which it is carried into the main drain. Dryness in the storage

* Dr. F. M. Hexamer, "Cold Storage Fruit House," Amer. Agric., Jan. 30, $1897,135$. 
room being of prime importance, the floor should be cemented whenever existing conditions permit. Of course, ample provision has to be made for thorough drainage, ventilation and circulation of air. Several devices for the accomplishment of this have been patented, and an excellent non-patented plan is minutely described and illustrated in Theron L. Hiles' book on the 'Ice Crop.' The general construction of the walls, roof, ventilation, etc., of such a storage house does not differ materially from that of ordinary ice houses. If the storage house is used much during hot weather, the greater part of the ice will probably have melted before the fall fruit comes in. It will therefore be necessary to have a reserve ice house near by, from which the storage house can be replenished."

The requisites for keeping grapes during the winter are given as follows by George C. Snow:* "Any good building in which the temperature can be held even at about $35^{\circ}$, with ventilation as may be required, this to be determined by noting how the fruit is keeping, will be found available for grapes. No positive rules can be laid down. A cooling room, in which the fruit can be first cooled, is a necessity. If placed directly in cold storage, the temperature will be found to be raised rapidly by placing a quantity of warm fruit in the room. As even a temperature as possible is much the best. Grapes should not be packed in baskets for shipping before being stored. They should be ripe, as grapes do not mature after

*Rural New-Yorker, Feb. 1, 1896 ; Bull. 117, Cornell Exp. Sta. 
picking. Niagara or any other variety ean be held only for a limited time, some varieties longer than others."

The following temperatures at whieh a cold storage company (Genesee Fruit Company, Rochester, New York) engages to hold certain products, will be interesting to the hortieulturist:

\begin{tabular}{|c|c|c|c|}
\hline GOODS. & Temp. & GOODS. & Temp. \\
\hline Apples* ............... & $33^{\circ}$ & Lemons............... & $36^{\circ}$ \\
\hline Berries ................ & 40 & Maple syrup............ & 35 \\
\hline Canned goods ........... & 35 & 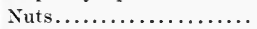 & 35 \\
\hline Celery $\ldots \ldots \ldots \ldots \ldots \ldots$ & $3 \tilde{5}$ & Oranges .............. & 36 \\
\hline Cherries.............. & 40 & 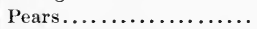 & 35 \\
\hline Cranberries ............ & 33 & Peaches or plums....... & 35 \\
\hline Dried berries........... & 35 & Prunes ............... & 35 \\
\hline Dried apples............. & 35 & Quinces .............. & 35 \\
\hline Dried corn.............. & 35 & 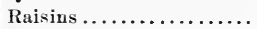 & 35 \\
\hline Dates ................. & 35 & Vegetables............. & 35 \\
\hline Evaporated apples....... & 35 & Wine ................ & 40 \\
\hline Figs..$\ldots \ldots \ldots \ldots \ldots \ldots$ & 35 & Watermelons ......... & 35 \\
\hline Grapes ................ & 36 & & \\
\hline
\end{tabular}

Storage buildings.-There are many fashions in which storage houses may be built for home use.

* Apples are often carried as low as $30^{\circ}$.

Note.-The director of the Genesee Fruit Company writes under date of May 22, 1897, as follows: "We carry apples at a temperature of 30 degrees, and we would advocate carrying them at 29 degrees for the first month in storage. Apples are going out of our warehouse in perfect condition ; in fact, there was one small lot, eonsisting of 198 barrels of Baldwins, which went out two weeks ago, and they were all run (or sorted), and the shrinkage oceasioned by decay was $1 \frac{1}{2}$ barrels. One of the most essential features in earrying apples is getting them in storage directly after they are picked from the trees, and we do not advocate receiving Greenings for storage after October 20." 
Fig. 107 shows a simple fruit-house, with tiers of trays upon either side of a central passage-way. The chimney and the area in the floor allow of change of air. Fig. 108 is a fruit-house of the late Charles Downing, of pomological fame. Whatever the style of the fruit-house, the walls above the surface of the ground should be well provided with airspaces. The accompanying details of the construction of celery houses (Figs. 109, 110), will suf-

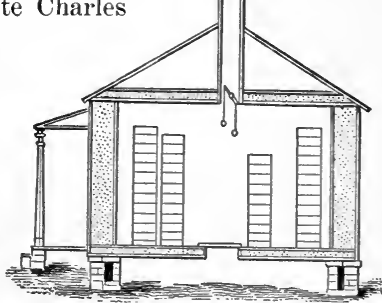

Fig. 107. Simple fruit-house. ficiently explain some of the problems which should be considered.* "This structure has a brick foundation, and the roof is well provided with air chambers and paper linings, affording the best protection against cold. The additional large air chamber above the collar beams, with its separate windows, seems also desirable. There are large double doors at each end, and the space between each outer and inner door is large, and the connections are well arranged for the exclusion of cold air. It seems of sufficient interest to give a view of such a storage house; but full details of construction may not be entered upon in this connection. It will be seen that Fig. 109 shows the construction of the peak and collar-beam (k) of the house, and also of the ventilator (1.1). Fig. 110

*B. M. Duggar, Bull. 132, Cornell Exp. Sta. 
shows the details of the roof construction. The plate (h) is lield firmly to the wall by a tongue (i) let into the brick work. The rafter is b. On this is a thickness of sheathing upon either side $(a, e)$, with

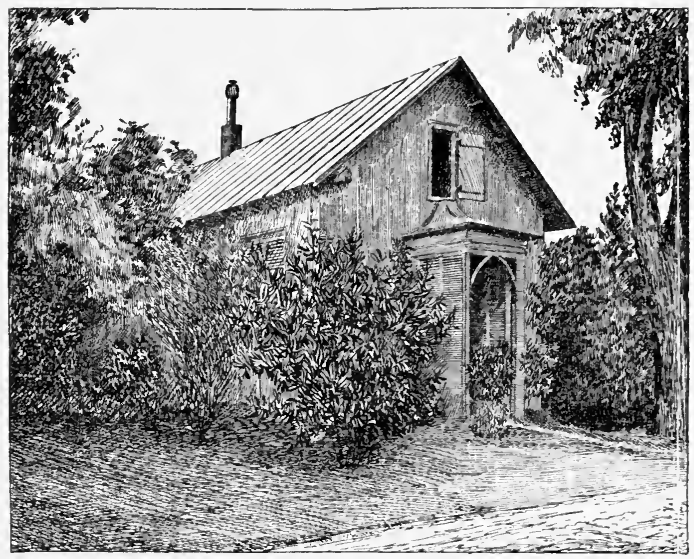

Fig. 108. Charles Downing's fruit-house.

an air-space at $e$, and onter sheathing at $\mathrm{g}$, and building paper at $d$ and f." Bnildings made upon this plan, or one similar to it, are efficient for the storage of either vegetables or fruits.

Waugh* gives the bill of lumber entering into the fruit-house in Fig. 111 (page 449) as follows:

" Apple Growing in Grand 1sle County," Bull. 55, Vermont Exp. Sta. 


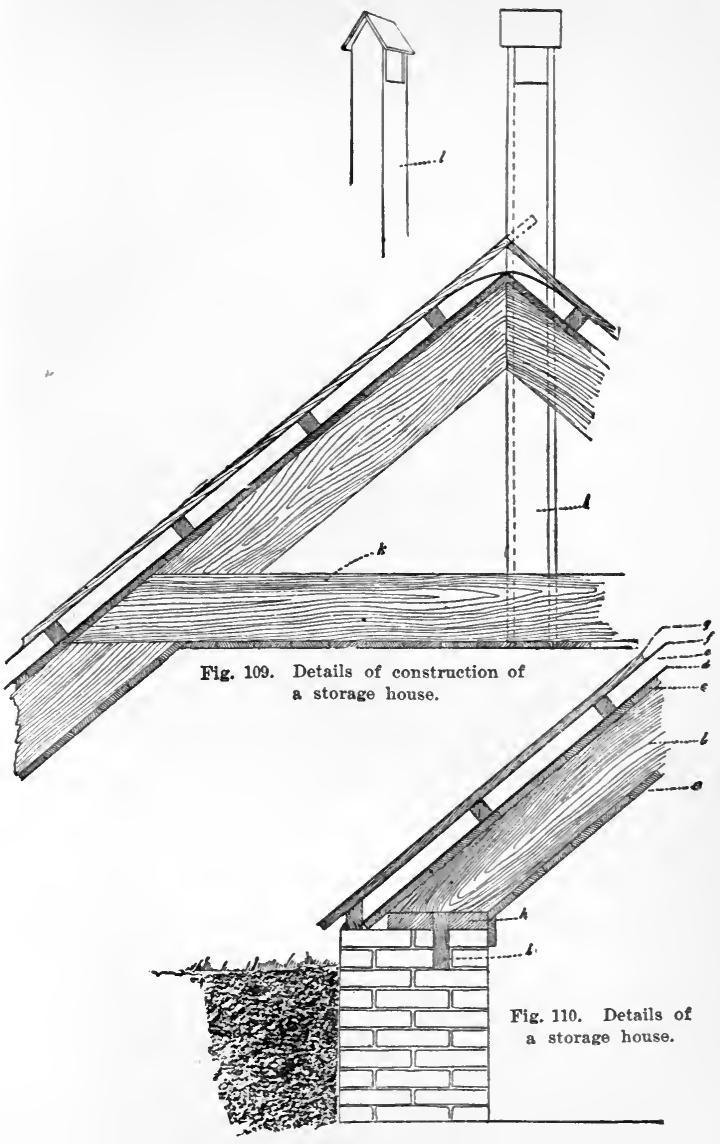


Bill of Lumber for Apple House.

3,500 feet wall boarding.

3,000 " roof boarding.

3,500 " eeiling (insicle).

7,200 " floor boards (double floors).

4,000 " clap-boards.

25 bundles lath.

$221 / 2$ squares slate.

OUTSIDE FINISH.

200 feet 5 -in. crown mold.

190 " 3 -in. bed mold.

300 " $7 / 8 \times 10$ mold for frieze and facia.

200 “ $7 / 8 \times 7$ base and water tables.

200 " $7 / 8 \times 12$ planers.

Lineal measure.

$$
4 \text { pieces } 7 / 8 \times 5,15 \text { feet. }
$$

4 " $7 / 8 \times 6,15$ " $\}$ Comer boards.

$\left.\begin{array}{rllllll}8 & \text { " } & 2 & \mathrm{x} & 8,15 & \text { " } \\ 16 & \text { " } & 2 & \mathrm{x} & 8,13 & \text { " }\end{array}\right\}$ Sills.

$\left.\begin{array}{lllll}56 & \text { " } & 2 & \times 9,15 \mathrm{l} / 2 & \text { " } \\ 26 & \text { " } & 2 & \times 9,30\end{array}\right\}$ Floor joists.

26 " $11 / 2 \times 9,19 \quad$ " Collar ties to rafters.

$\left.\begin{array}{rrrrrr}100 & \text { " } & 3 & \text { x } 4,14 & \text { " } \\ 20 & \text { " } & 3 & \text { x } 4,12 & \text { " }\end{array}\right\}$ Wall studs.

56 “ 2 × 5 8, 21 “ $\quad$ Rafters.

$\left.\begin{array}{lllllll}26 & \text { " } & 2 & \times & 6,10 & \text { " } \\ 26 & \text { " } & 1 & \times 6,8 & \text { " }\end{array}\right\}$ Braces.

16 " 1 × 4,13 " 13 Ribbons.

4 " $2 \times 12,13$ " Ridge poles.

The owner of this house (T. L. Kinney) gives the following information (See Fig. 112): "The fruit house is built on high and dry ground. The cellar was three feet, and dirt taken from this was nsed to bank up around the wall. The wall is solid stone and mortar, is five feet high, two and one-half feet wide 
at the bottom, and two feet at the top; two-inch plank for sills on this, bedded in mortar, doubled so as to break joints; two by four studding above this; outside of studding matched pine, then paper, and then clap-boards, painted; in middle of studding, lath

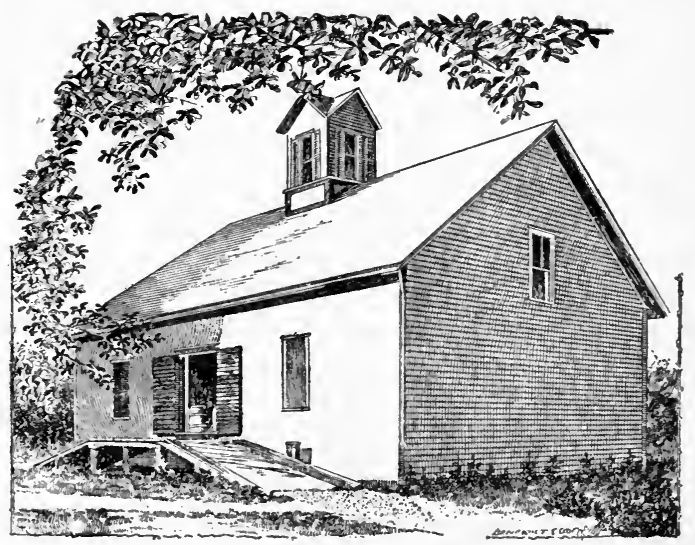

Fig. 111. Apple house; from the islands of Lake Champlain.

and plaster; inside of studding, matched pine, then paper, and then one-half-inch sheathing, painted. This gives two hollow walls, or dead-air spaces. For ventilating, there is one ventilator from cellar to the observatory on top of building, which has four large window frames, with blinds, but no tight windows. The ventilator opens into both storage rooms. We 
have three eighteen-inch windows on east and west sides of building in the cellar, and three large windows in west side, next to store room. Both floors are double, with paper between, and the second room is ceiled overhead with matched spruce, and painted. The two windows on east side show in cut, with the outside doors.

"About picking time, we begin to cool off the building by keeping open during westerly winds or cold waves, and closed as much as possible when it is warm. We try not to put in any fruit when the fruit is warm, but have it cool, if possible. In this way the air in the building is cool all the time. I have kept a partial daily record of the temperature in the cellar this winter $(1896-7)$ since December 28 , the results of which are as follows:

\begin{tabular}{|c|c|c|c|c|c|}
\hline \multicolumn{3}{|c|}{ CELLAR. } & \multicolumn{3}{|c|}{ SECOND ROOM. } \\
\hline & DATE. & Temp. & & DATE. & Temp. \\
\hline \multicolumn{2}{|c|}{ December $28 \ldots \ldots \ldots \ldots \ldots$} & $35^{\circ}$ & \multicolumn{2}{|c|}{ December $28 \ldots \ldots \ldots \ldots$. } & $32^{\circ}$ \\
\hline ، & $29 \ldots \ldots \ldots \ldots$ & 35 & 6 & $29 \ldots \ldots \ldots \ldots$ & 33 \\
\hline January & $1 \ldots \ldots \ldots \ldots$ & 36 & January & $1 \ldots \ldots \ldots \ldots$ & 33 \\
\hline 6 & $2 \ldots \ldots \ldots \ldots$ & 36 & " & $2 \ldots \ldots \ldots \ldots$ & $3 \tilde{5}$ \\
\hline " & $3 \ldots \ldots \ldots \ldots$ & 36 & " & $3 \ldots \ldots \ldots \ldots$ & 37 \\
\hline "6 & $4 \ldots \ldots \ldots \ldots$ & 37 & " & $4 \ldots \ldots \ldots \ldots$ & 38 \\
\hline "6 & $7 \ldots \ldots \ldots \ldots$ & 37 & " & $7 \ldots \ldots \ldots \ldots$ & 36 \\
\hline$" 6$ & $11 \ldots \ldots \ldots \ldots$ & 37 & " & $11 \ldots \ldots \ldots \ldots$ & 35 \\
\hline "6 & $14 \ldots \ldots \ldots \ldots$ & 36 & " & $14 \ldots \ldots \ldots \ldots$ & 32 \\
\hline$" 6$ & $17 \ldots \ldots \ldots \ldots$ & 36 & $\because 6$ & $17 \ldots \ldots \ldots \ldots$ & 34 \\
\hline "6 & $19 \ldots \ldots \ldots \ldots$ & 36 & $" 6$ & $19 \ldots \ldots \ldots \ldots$ & 32 \\
\hline " & $23 \ldots \ldots \ldots \ldots$ & 36 & “ & $23 \ldots \ldots \ldots \ldots$ & 33 \\
\hline
\end{tabular}


"It will be seen by this that the temperature ranges from 35 to $37^{\circ}$ in the cellar, and from 32 to $38^{\circ}$ in the room above. This difference is occasioned by the cellar being nearly full of barrels of apples,

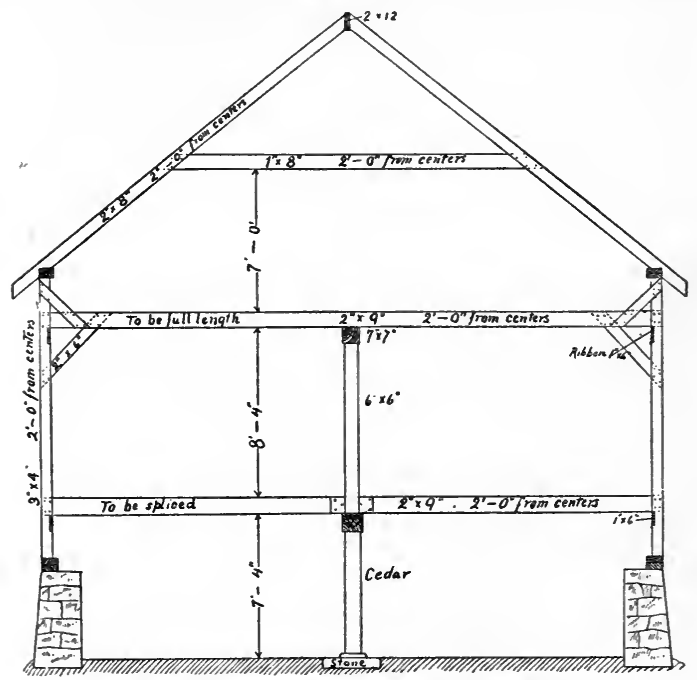

Fig. 112. Details of house shown in Fig. 111.

and the next room about half full; and we are passing in and out to the second room every day, and some days many times. The doors are large and high up, and only common doors. We had no snow until the 21st of January this winter, and it has been 
as cold as $18^{\circ}$ below zero at two different times, and as low as $10^{\circ}$ below zero several times. I have no fire exeept an oil stove, and have not used that yet. I think that winter apples will keep as well at a temperature of 36 as $32^{\circ}$; yet, I have no proof of it. I do not like to have the apples get too eold, as we have twelve miles to haul to the ear; and if the fruit is kept too cold, it is more likely to freeze on its long trip to market."

A "new plan for the construction of a storage cellar" is given by Alwood:*

"The winter storage of fruits and vegetables is a question of much importance in this state [Virginia] because of the wide range of temperature which prevails during that season. Also, temporary summer storage is a subject worthy of careful attention, and may be to some extent solved by eareful application of the principle explained in this article. The common practice for winter storage largely in vogue over this state, is to bury snch vegetables and fruits as are required for winter and spring use in outdoor pits. The particular method followed varies with the different kinds of erop to be preserved, but the essential facts are the same. This system of pitting ean hardly be considered a success so far as relates to the main erops stored; viz., apples and potatoes. The essentials of winter storage for apples and potatoes are a low, dry, even temperature, and to secure this without artificial cold storage is a problem that cannot be met by the outdoor pit methods of burying these staple articles. These two crops are necessarily held by growers in considerable quantity for winter and spring use, and the problem of storing them in a convenient and successful manner is the one had in view in the discussion which follows. It may be well to state at the outset that we doubt the even partial success of the plan herein explained for all of

*W. B. Alwood, Bull. 11, vol. iv., Va. Exp. Sta. 
that portion of the state lying east of Piedmont. Several years since, we concluded to construct a simple storage cellar upon a plan which we once heard discussed, but had not seen carried into practice. In fact, our building is the first one constructed en this plan of which we have any knowledge.

"The essential features involved in the storage building which we designed for this purpose are: First, a cellar excavated into a gently sloping hillside, carried into the bank far enough to place the cellar room entirely below the surface of the earth, and yet give opportunity to enter the cellar easily by an inclined way from the lower side of the slope; secondly, a flue leading out from near the center of the floor of the cellar room, along the bank of the hillside for a considerable distance, with sufficient fall to make it act both as a drain pipe and a fresh air flue; thirdly, ventilating flues placed at each end of the cellar room or elsewhere, as desired, and rising to the height necessary to give a sufficient draft to carry off rapidly the air from the cellar room whenever ventilation is desired.

"The cellar room will better serve the purpose of cold storage if the excaration is carried back into the bank so as to make the floor twelve or fifteen feet below the lowest point of the adjacent hillside. In the ease of the cellar built here, the excavation is only ten feet deep at the deepest point, but we are now satisfied that a greater depth would give better results. The principle of a subterranean air flue is the essential feature of this cellar. In its use we aim to secure a dry, even temperature in the cellar by admitting air as desired through this flue. It should be at least six inches in diameter and, we now think, should be laid, at a depth of eight or nine feet, along the bank of the hillside, for a distance of about five hundred feet. It is not necessary that this flue should lie in a straight line, but any departure from a straight line should be a gradual eurve, so as to permit an unobstructed flow of air into the cellar. Situated at this depth, and having a length approximately as stated above, the air flowing into the cellar through this flue will be in summer reduced, and in winter raised, to the temperature of the soil at the depth stated, which will 
approximate somewhere between $50^{\circ}$ and $55^{\circ}$ Fahr. during the entire year. The above statement is based upon the observed temperature of perennial springs in this vicinity.

"From the foregoing it follows that if the air in the cellar becomes warmer than the air in the underground flue, it will rise through the ventilating flues, and the colder air will flow in from the supply flise, as desired. The temperature of the cellar room can thus be approximately controlled to at least the neighborhood of $55^{\circ}$ to $60^{\circ}$ Fahr. The construction of the cellar is shown somewhat in detail in the drawings below. These figures are not intended as working drawings, but serve to bring out the essential ideas and plan of the structure sufficiently to enable any mechanic to carry them out on larger or smaller scale to suit the needs of the builder. Fig. 113 is a

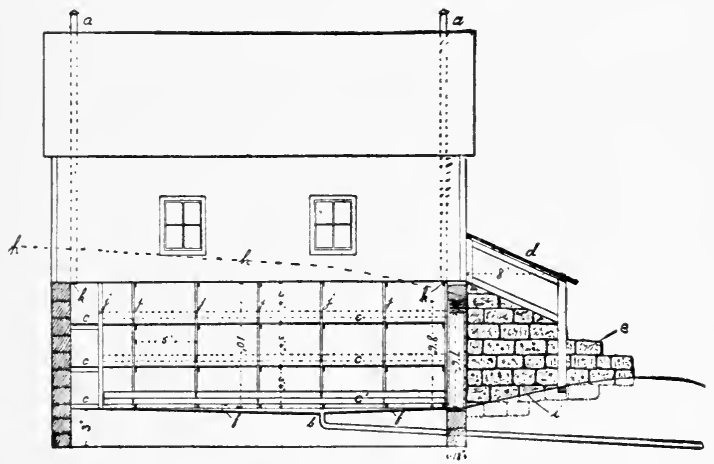

Fig. 113. Longitndinal seetion of Alwood's house.

longitudinal section through the cellar room, and shows also a side elevation of the storeroom above. The two ventilators $a a$ rise through the-storeroom, and are six inches in diameter by fifteen feet long, thus insuring good draft. The air flue $b$ 
enters under the foundation and discharges fresh air into the cellar room near the center. This flue is six inches in diameter, and theoretically should be extended far enough along the hillside to admit of tempering the air to the temperature of the

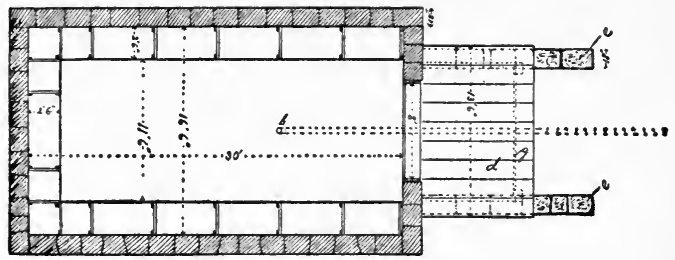

Fig. 114. Ground plan.

surrounding earth while passing through it. The cellar built here has an air flue only one hundred and fifty feet long, and we have never been able to cool the air down below $60^{\circ} \mathrm{Fahr}$. when the temperature of the outside air is above $70^{\circ} \mathrm{Fahr}$.

"The dotted line $h h$ shows the contour of the hillside, and the line $i$ shows the entry-way into the cellar. The entry-way should preferably be on the north side of the structure, and should be closed in by a vestibule, so as to protect the cellarway from storm, and to prevent influence of outside temperature upon the atmosphere in the cellar.

"The roof structure of vestibule is shown at $d$, and one of the side walls of the entry-way at $e$. The floor of the cellar $f f$ pitches slightly to the mouth of the air flue $b$, which serves as a drain pipe when one is needed. The cellar floor is made of broken stone and cement, and successfully checks the upward rise of ground water. The bins $c c$ and $c^{\prime}$ on one side of the cellar room are shown, with dimensions. They are constructed of two by four seantling and one inch oak boards. At $c^{\prime}$ the facing on lower bin is shown in position. When we desire to fill the bins additional facing boards are used. The letters $k k$ 
at lower ends of ventilating flues indicate position of sliding dampers, by means of which the flow of air from the cellar is effectually controlled. With the short flue used in the cellar here, we find that when the mercury remains below $20^{\circ} \mathrm{Fahr}$. for any length of time the cellar will be reduced below freezing, unless the ventilators are closed.

"The dimensions of the ground plan of the cellar are shown in Fig. 114. The letters so far as used always indicate the same part of the structure in the several figures. This figure shows the walls to be constructed of stone, which is unquestion. ably the proper material. In our building, which was constructed to test the practicability of an idea new to this elass of structures, expense was avoided so far as possible, and the walls are built of wood. The framing of the walls is constructed of two by four scantling framed into sills laid in broken stone and cement. The corner posts are four by four seantling. This frame is covered outside by a double sheathing of inch oak plank. The first course was put on diagonal and covered with strong builder's paper, and over this a perpendicular course of sheathing was put on. The whole structure was then literally soaked with crude petroleum, and the earth rammed in tight around the cellar story and banked up, so as to carry surface water away from the walls. Inside the walls were covered with inch oak boards, and the bins constructed as indicated in the drawings. The entry-way to the cellar is wide enough to admit of backing a horse-cart or wagon down into the cellar, so as to unload directly from it. This is a matter of much convenience to the workmen. The width of the cellar floor will permit of a row of barrels being placed in front of the bins and yet admit the vehicle.

"A series of observations on the range of temperature in the cellar was made during November, December, January and part of February, and the results are summarized below. The ventilator and the supply air flue were all left open from November 1 to December 10. The outside air temperature registered $28^{\circ}$ on the morning of the first of November, and the cellar showed a temperature of $46^{\circ} \mathrm{Fahr}$. As the month progressed, a period 
of warm weather set in, without a drop to freezing from the 7 th until the 24th of the month. During this time the temperature often registered above $60^{\circ}$ in the shade, with maximum readings considerably higher. The cellar temperature varied just $12^{\circ}$ for the entire month, reaching $58^{\circ}$ on two occasions, but elosing the month at $46^{\circ}$, with outside temperature at $34^{\circ}$. During December the cellar temperature was reduced quite steadily from $45^{\circ}$ to $38^{\circ}$, the daily variations being at most $2^{\circ}$. Outside temperature varied considerably, but the range was between $15^{\circ}$ and $46^{\circ}$. Quite a number of observations was made on the working of the supply flue and the ventilators. The tests made showed that air passed through the one hundred and fifty feet supply flue in thirty to forty seconds, and the ventilators could be depended upon at all times to keep up a movement of air in the cellar so as to draw a fresh supply. In fact, during the coldest weather we frequently elosed the ventilators to prevent the too rapid lowering of the temperature in the cellar. The tests showed that this short flue could not be depended upon to raise the air to a proper temperature when the mereury outside was at $15^{\circ}$ or lower. Our observations showed that the air was, under these circumstances, raised about $20^{\circ}$, varying, of course, with conditions. During January further experiments showed that we could quite easily reduce the cellar temperature to $35^{\circ}$ when the outside air registered $15^{\circ}$ to $20^{\circ}$. However, the building proves to be lacking in two essentials to hold the cellar temperature stable; viz., it is not deep enough in the earth, and the floor between it and the tool-room above is not properly laid. This floor is made double, of half-inch stuff, while we now see that the cellar-room should also be ceiled in the best possible manner, to prevent interference by outside changes of temperature. The total range in the cellar during January was $35^{\circ}$ to $42^{\circ}$. This result was, however, seeured by carefully watehing the conditions, so as to admit cold air during the night or periods of low temperature and then closing the flues when the outside temperature would act injuriously upon the temperature of the cellar. With the temperature fluctuations which prevail in this region, much attention is necessary to properly control the conditions in the cellar." 
Alcoholic vapor as a fruit-preservative.-In connection with cold storage, it may be possible to experiment with the "new process for keeping fruit fresh," which was published in 1895 by the Department of State (Burean of Statisties, by Henry P. DuBellet, Consul at Rheims, Franee), and distributed by the Division of Pomology of the Department of Agriculture:

"The great difficulty experienced in preserving fruits in their natural state is such that the dealers who make the attempt of furnishing them out of season are compelled, on account of the heavy losses they sustain, to sell their goods at prices which render it impossible for the great majority of families to place fresh fruits on their tables during the winter months. The high prices which fresh fruits command on the eity markets increase day by day from the time they are gathered, and have induced orchard and vine owners to run many risks in order to keep their fruits as long as possible before offering them for sale. And it is not surprising that no pains, efforts, and sacrifices are spared to reach the coveted result, when it is known that during these last years, first-class grapes sold from 2 to 4 franes (38.6 to 77.2 cents) per kilogram (2.2 pounds) from September to November, that they were worth 8 franes (\$1.53.4) and as much as 12 franes (\$2.31.6) in February and Mareh, and 14 franes (\$2.70) in April and May.

"These exorbitant prices show plainly how imperfect are yet the means employed for keeping fruits fresh, how few must be the successful efforts, and how many the difficulties encountered. The solution of this question is, therefore, of great interest to all, and the result of the experiments made in the latter part of the year 1894 and lately reported to the Horticultural Society of Soissons by Mr. A. Petit, chief of the laboratory of horticultural researehes at the National Horticultural School of Versailles, deserves the attention and consideration of fruit-growers throughout the United States. 
"Impressed with the powerful action of alcoholic vapors on the mold which generally appears on the surface of fruits in a damp atmosphere, Mr. Petit noticed that pears and apples kept for several months in a surrounding saturated with vapors of water and alcohol, even were they at the beginning in a state of decay, showed no signs of mold, while fruits in every particular identically similar to the former, stored under the same conditions, but not exposed to the action of alcoholic vapors, were entirely covered with it.

"Taking advantage of this observation, Mr. Petit applied the principle to the preservation of fruits in general, and most particularly to grapes, because, more than others, the latter are subject to mold. It was to be foreseen that grapes kept, from the day they are cut off the vines, in an atmosphere saturated with vapors of water and alcohol would, by the retarding of the sweating period, not only remain free from mold, but would even retain their natural aspect. Consequently, should the temperature be constant and low, the preservation could be maintained long and well.

"On the 31st of October, 1894-that is, very late in the season and at a very unfavorable time-Mr. Petit placed, with other fruits and a bottle filled with 100 cubic centimeters (61 cubic inches) of alcohol at $96^{\circ}$, some bunches of grapes known as 'Chasselas de Fontainebleau,' fresh from the vine, in a brick recipient in the form of a parallelopiped, cemented inside and closed as hermetically as possible by a common wooden door. In two similar recipients contiguous to the first, one of which was kept open and the other closed, but without alcohol, were stored similar fruits from the same trees and vines. The fruits were laid on wood shavings. The recipients were built in a very damp cellar, the temperature of which varied regularly from $10^{\circ}$ to $8^{\circ} \mathrm{C}$. $\left(50^{\circ}\right.$ to $46^{\circ} \mathrm{F}$.) during the whole time the experiment lasted.

"On November 20, the grapes placed in the recipent left open, and especially so those in the closed recipient without alcohol, vere mostly rotten and covered with mold, and were immediately removed. In the recipient containing the bottle of alcohol, the 
grapes were beautiful; on one bunch, two grapes had turned brown, but were firm, full, and free of mold; they did not taste at all sour, thus differing essentially from moldy grapes, espeeially those subject to Penicillium glaucum. The hair hygrometer in the recipient registered $98^{\circ}$. On December 7 , the bunches of grapes in the recipient containing the alcohol had kept their fine aspect; on most of them, however, one or two grapes had turned brown, and were in the same condition as those above referred to. On December 24, same results; on most of the bunches could be seen one or two grapes commencing to decay. At the end of nearly two months, each bunch had lost but from two to four grapes each and all were in a perfect state of preservation, the stalks being perfectly green and the grapes firm, full, and savory, and having all the qualities of fresh-cut grapes.

"At the conclusion of the experiment, 28 cubic centimeter's (17 eubic inches) of alcohol at $60^{\circ}$ remained in the bottle out of the 100 cubic centimeters (61 eubic inches) at $96^{\circ}$, but, as $\mathrm{Mr}$. Petit remarks, the door of his recipient had not been built with great care and did not close hermetically, hence a useless consumption of alcohol.

"This process offers many advantages. It is simple, easy of application, and eheap, and, if adopted by our fruit-growers, would allow them not only to hold their fine fruits until they can dispose of them at a fair price, but would also insure them handsome profits during the winter months."

Beckwith makes the following note* upon this method: "For the purpose of testing the process as described in the above circular, two fully ripened branches of Norfolk grapes were placed, together with two ounce bottles filled with alcohol, upon a large pane of glass and covered with a glass bell jar. The grapes thus prepared were placed upon a table in my laboratory, where they remained until December 18, perfectly sound and plump in appear-

* Eighth Ann. Rep. Del. Exp. Sta., 110. 
ance, but had changed to a slightly darker brown color. The flesh was sound and firm, and still retained nearly its normal flavor. The grapes remainded under the treatment until February 10, when they were removed. At this date, nearly all of the grapes were firm and plump, a few having become somewhat shriveled. They had a peculiar alcoholic taste, having entirely lost their normal flavor. The flesh was very firm, and of a light brown color. The above was, of course, a severe test of the process for keeping fruit fresh, and could not be considered a success. It is possible that by placing the fruit in a cool apartment it could be preserved for a considerable length of time without any great expense."

SHIPPING, AND REACHING THE CONSUMER.

The grower and the consumer.-The means to be employed in reaching the consumer are such personal matters that little specific advice can be given upon the subject; and the suggestions which are here made are not meant to apply to the buyers of fruit, nor to those growers who sell their fruit to itinerant buyers. It should first be said that the fruit itself is the best business card which the grower can have, in the long run. Fruit which is well grown and well packed is already virtually sold. If the consumer is convinced of the honesty and good faith of the grower and the packer, then his suspicions are allayed, and he is willing to purchase 
freely, and at a fair price. If the grower's name is upon the package, it becomes a guaranty of the quality of the fruit, and the consumer buys confidently. If, in addition to this, there is some neat and unique label attached to the package, the consumer will be convinced that his grower is not only willing to be responsible for the quality of the fruit, but that he is also a man of business instincts. It has recently been remarked that the Canadian apples which are shipped into the American markets bring a better price than the domestic products, and very largely for the reason that the law demands that the fruit should be marked "Canadian grown," and the grower ordinarily places his name upon the parcel. The buyer in such ease knows who is to be held responsible for the product in ease it does not come up to his expectations. The time is certainly coming when an inferior grade of fruit cannot be put upon the market with profit. Competition is gradually increasing, and it is only the better grades which can pay for the expense of shipping and packages and selling, and leave a margin of profit to the grower.

The gist of the successful distribution and selling of fruit lies in searching out the best markets, and then in finding out what the consumer wants. This ean be done only by giving as much attention to the market end of the business as to the distinctly agricultural end of it. The grower who expects to handle his own fruit directly should visit the markets, and should take particular pains 
to determine the especial types and brands of fruit which the consumers in that market require. It is generally true that the fruit-grower raises whatever comes handy, and sells it if he can. It would be better business to determine what the market is likely to demand, and then to grow the article that is wanted. The essence of modern trade is the specialization of business and the individualizing of the consumer. The person who has much fruit of good quality to sell should begin to look up his markets some weeks in advance of the market season; and he will ordinarily do well to sell somewhat by sample. Regulation packages, with his accustomed grade of fruit, may be sent here and there to dealers and consumers, to represent the product which he has for sale. Much of the success of this type of marketing depends upon the quantity which the grower can provide. Dealers ordinarily demand that the grower furnish them with stated quantities of stated varieties; and if the grower cannot do this he may be unable to hold his customer, and must simply meet the vagaries of an incidental trade. The grower or shipper should notify his dealer in advance as to the amount and quality of fruit which will be likely to reach him at any given time. The dealer is then able to inform his customers and to find an outlet for the product. It should be remarked that this matter of finding a market is a perennial enterprise; that is, it is onc which must be renewed every year, for the market of one year may not 
be the best market for the following year. The market details should be followed up with the same thoroughness which the grower gives to the new development in varieties, and in means of contending with fungi and insects.

The selection of the middleman, throngh whom the fruits are to be sold, is one of the most important features in the whole range of fruit marketing. The first requisite is that this man shonld be honest and capable. Then the grower should place great confidence in his judgment, for, as he is nearer the point of consumption, his advice should be worth much more than the judgment of one who is far away. Too many growers are guided in their selection of a merehant by high quotations and flattering letters which are sent ont at the beginning of the fruit season, but it is often true that the man who at the beginning of the season makes the most moderate and conservative quotations, is the one who secures the most profit for the grower in the end.*

If one is to reach special and personal markets, the small package is nearly always advisable; but in the wholesale and impersonal methods of marketing, the large package will no doubt prove to be the most economical, not only because it costs less for a certain quantity of fruit, but becanse the expense of packing is less. In the early days of commercial fruit shipping in this country, the large

\footnotetext{
* For a sketch of the rise of the auction system of selling fruits in this country, see Annals of Horticulture for 1892, p. 40 .
} 
package for peaches and other tender fruits was commonly used. Peaches were shipped almost wholly in bushel baskets. With the increase and specialization of the business, however, smaller packages were in demand, and in some of the largest peach regions of the country, the product was finally shipped in fifth and sixth-bushel baskets. Now that the production has come to be enormous, however, and the returns to the individual grower are comparatively light, there has again arisen a demand for the large package. All this is well illustrated in the Lake Michigan region, in which the bushel basket has recently come into great use. The probability is that if the low price of grapes continues for a few years, there will arise a great demand for a larger package. The individual grower who has a special market to reach, however, will still find that the small package is as useful as ever, and it may perhaps have an added advantage because of its contrast with the larger ones in eommon nse. There is likely to be, therefore, a differentiation in the use of fruit packages, tending upon the one side towards a larger wholesale package, and on the other towards a small retail and personal package.

It should be said in passing that one reason why the small package falls into disfavor is because the fruit is so completely packed by hand that there is a great temptation on the part of the grower to include fruits of poor quality, or at least not to keep up the standard of an arbitrary grade. When 
large paekages are used, and the grades are not so carefully made, there is less reason for finding fault with a few poor fruits. It is also true that many of the packages, especially in the handling of peaches, have been too small to allow of thoroughly honest paeking. This is true of the fifth and sixth-bushel baskets especially. They are either too high or too low to allow a given number of full tiers of fruit to be placed in them, and in order to bring the top layer up to its required height, it is often necessary to insert a layer of small fruits somewhere below the top ; and this small fruit is commonly placed in the middle, because the paeker eannot always diseover if he must use it until the package is partially filled.

In the distribution of fruit, it should be remembered that the establishing of a reputation for the fruit is quite as important as the securing of a remunerative price for the present samples; therefore, the inferior fruits and eulls should be kept in the home markets, or manufactured into cider or other seeondary products; or, if shipped, they should be plaeed upon the market without guaranty and without the grower's name. They are then sold simply upon their merits, without the recommendation of the grower's name or any attractive label or deseription.

Refrigerator cars.-Fruit which is of superior quality will pay for considerable extra effort in transportation. If it is of a perishable nature, and the market is more than six or eight hours away, 
it may pay to ship in iced cars, particularly if the weather is very warm. In shipping fruit in ieed cars, it is important to know that the car should be iced some time in advance of its receiving the fruit. This is for the purpose of completely cooling off the car. The ice should be put in at least six hours in advance of the loading, if possible, and a longer time is very often advisable. The transportation companies should be notified in advance of the" number and route of the ears which are shipping, in order that the ice may be renewed at the necessary intervals. It may be said, also, that the car should not be completely filled with fruit. The upper part of the car is apt to be very hot, especially in summer, and if space is left above the fruit there is better opportunity for ventilation. About three hundred bushels of fruit in bushel packages should be the limit of the amount in any one car.

Earle writes* as follows upon shipping in refrigerated cars :

"Many difficulties and much prejudice were formerly encountered in shipping fruits under refrigeration. Dealers and buyers were afraid to handle fruits that had been on ice, claiming that they would melt down and spoil as soon as they were removed to the warmer air. This belief was widespread and deeply seated, and it has taken much time and many practical demonstrations to fully convinee the trade of its falsity. It probably originated in attempts to save fruit. that was already over-ripe, and on the verge of spoiling, by placing it in the ice-box. Such fruit will be preserved for

*F. S. Earle, Bull. 79, Ala. Exp. Sta. 
some time, if kept cold enough, for cold arrests the growth of the organisms of decay. The decay is only arrested, however, for these organisins are not killed by the cold, and as soon as sueh fruit is again brought into a warm atmosphere they rapidly complete its destruction. If, however, the fruit is taken from the field at the proper stage of ruaturity, and is placed at once in a refrigerator car, the cold prevents the beginning of incipient decay; and the fruit will arrive at its destination in a condition to keep almost as long after taking it from the ear as it would lave kept in the open air at the time it was picked. Strawberries must be in the best possible condition, and the weather not too hot, for them to stand thirty-six hours' transportation by express; or, in other words, for them to reach market in good condition on the second morning after picking. In the writer's experience, strawberries have been repeatedly sent from southern Illinois to Detroit, a three-days' run, by refrigerator freight, and have been suceessfully reshipped by express to Canadian points that were not reached till the second morning after leaving Detroit.

"Again, no fruit is more perishable than a fully ripencel peach; but peaches fully mellow, and ready to eat, have been put in refrigerator ears in California, and, after a six-clays' run to Chicago, have been reshipped by express to New York, reacning there in condition to bring good prices. Of eourse, to endure such severe tests, it is necessary to have the fruit very carefully assorted and paeked. A very few specked peaches or rotting strawberries would spoil an entire package before reaching so distant a market. Good judgment, too, is necessary in picking fruit at the proper stage of maturity for refrigerator shipment. Of course, it should not be too ripe, but the mistake is much more often made of picking it too green. In shipping by freight in open ears, it is often necessary to pick rather green, but with most fruits this is done at great sacrifice of quality. Under refrigeration, fully matured ripe fruit will keep better than that which is grass green. This is an important point in favor of refrigeration, and one that many growers do not understand, for it enables 
fruit to be put on the market after its full flavor and quality has been developed. The flat, insipid quality, and lack of flavor so often noticed in California fruits on the eastern markets, comes very largely from the pernicious habit of green picking. A peach that is ripe enough to be fully mellow is hard to handle without bruising, but they should hang on the tree till fully grown and colored. A peach that would be mellow if left on the tree till to-morrow, is in just the right condition to pick to-day. Pears, on the other hand, should be picked green, at least ten days to two weeks before softening, and should be ripened in a close, dark place. For this" reason, they can be safely shipped in tight boxes or barrels in open ears, unless it is intended to place them in cold storage on arrival. In this case, they should be shipped under refrigeration, to retard the ripening process as much as possible.

"Refrigerator cars were first built for the meat trade. The meat was hung in cold-storage houses, and was loaded into the ears at or near the freezing point. In a tight, well built car such a cold load would warm up very slowly, and a small amount of ice served to carry it safely to its destination. When it was attempted to use these cars for fruit, the hot load, fresh from the fields, soon melted the limited ice supply, and the cars invariably arrived heated and in bad order. To use these cars successfully, it was found necessary to build cooling houses at the shipping points, in which the fruit could be cooled off before loading, as in the ease of the meat. This caused delay in getting the fruit on the market, and made much additional expense. It, however, demonstrated the success of refrigeration for the transportation of fruits, and soon ears were built especially for the fruit trade, with sufficient ice capacity to cool off a load of hot fruit in transit, and to keep it cool. At the present time there are a number of refrigerator car lines, with specially built fruit ears, that are actively competing for the fruit and vegetable carrying trade; so that any point, having sufficient business to offer, can secure efficient car service, with competent men to look after the proper loading and icing of the 
ears. Each line, of course, claims to have the best ears; and for difficult service there would certainly be considerable choice between them, but with the numerous re-icing stations that are now available, any of them will give satisfactory service, if properly loaded and liandled.

"The main points to consider in selecting a refrigerator car for transporting produce are first, its ice capacity, and second, its insulation. The ice tanks should hold at least five tons of ice, and six tons is even better. The position of the tanks, whether overhead or at the ends, is a question of minor importance. The car should be tightly built, with double walls and roof, with the space between them filled in with some nonconducting material, or by numerous linings of building paper, with dead air spaces between them. The doors should be built like the walls, and be of the same thickness; and they should fit as nearly air-tight as possible. Of course the car should be sweet and clean.

"It is usual for the refrigerator companies to furnish their own men for loading the cars, for proper loading is a point of so much importance that they do not care to trust the reputation of their ears to inexperienced men. The important points to secure in loading are first, that the packages be so spaced that the cold air has immediate access to all sides of them, and second, that they be so secured that the load cannot shift by the bumping of the cars while in transit. These points are usually secured by piling the crates or other packages one above another in tiers or ranks, from three to six inclies apart, and with lath or strips between each layer. Strips are placed upright against the end of the ear, and a row of packages is placed on the floor, with the ends set snugly against these strips, and carefully spaced. Light half-inch strips, as long as the width of the car, are placed across the ends of the packages; and the front one is nailed down with a light nail to the head of each package, to prevent side shifting. Another row of packages is placed on these strips, each one directly above one in the lower row. These are again stripped and nailed, and so on to the top. The 
next course is placed with the ends snugly against the ends of the first course, so that the air spaces are continuous. When the center of the ear is reached, begin in the other end and load in the same way. A space will usually be left at the last, too narrow to admit another course of packages; and the car must now be braced, to prevent the courses from shifting endwise. Pieces of one by six inch boards are set up against the ends of each rank of packages, and other strips are nailed across these uprights, near the bottom and the top of the car. The distance between these opposite cross-pieces is now carefully measured, and pieces of board are cut for braces about an inch longer than this space, so that they will have to be driven home with considerable force. The braces are toe-nailed in place, to prevent their falling, if they should chance to loosen in the bumping of the ear. When thus loaded and braced, the contents are absolutely immovable, yet each package is separated from its neighbors on all sides by a layer of cold air, which, when it becomes warmed by the hot fruit, rises, and is carried by the currents thus generated to the ice, where it is quickly cooled again, and where it deposits the moisture that may have been taken up from the fruit. This rapid circulation of the air is very important, and the ice, instead of making the fruit damp, as might at first be thought, really serves to dry it very effectually."

Shipping associations. - In many parts of the country, the grower, if he is a good business man, can find a special market for all that he can raise; but, in general, it is no doubt true that a thoroughly competent organization of fruit men is the best means through which to distribute fruit. Such an organization should make it a particular business to determine just where the best markets are, and to make out lists of those towns which are within practicable reach of the fruit region, with the popu- 
lation and the consuming capacity of each, the transportation rates thereto, and all incidental matters which are likely to influence the market from day to day. Having such information before it, the association, if it has the shipping of the larger part of the fruit of any region, ean place such quantity in each eity or town as can be consumed, and thereby prevent the glutting of the markets. All this ean be done only when the system of organization is exceedingly thorongh and when the growers are willing to coöperate; but it would likely be a mistake for any organization to expect to enlist in such an enterprise those fruit-growers who are able to find special and personal markets for themselves. as indicated in the next paragraph. Such growers are ordinarily so few, however, that they do not influence the general market conditions.

Much has been said during the past few years about the shipping of fruit in pools or unions. When the market is very far removed from the producer, so that transportation rates are high, an organization of interests is often necessary. In districts which are so far from markets as the Pacific coast, it is necessary that a man have either a large quantity of fruit to ship or that he ship in conjunction with his neighbors; or, that he sell his fruit outright to buyers. In districts which are close to market, it is rarely advantageous to the growers of the very finest fruits to ship through pools or unions. The difficulty is that the best fruit is sold for about the same price that the poor fruit 
is, and it is very rare that all the growers of any locality pack their fruit in the same degree of excellence. If the union were to exercise very stringent oversight over the packing, this difficulty might be overcome. If, for example, the fruit were brought to the union in the trays or erates directly from the field, and were then re-packed uniformly before shipment, and each grower paid for the exact amount of good fruit which he delivers, the union might prove to be very advantageous, because there should be an economy in the purchase of baskets, in the cost of packing, in transportation rates, and also in the finding of the best markets. The unsatisfactory results which have arisen from fruit unions have not come from inherent difficulties in the system so much as from the lack of a thorough business system of oversight to the packing and grading of all the different samples which are submitted.

The number of persons who ean and will grow a dessert quality of fruit is very few, and such persons can really not afford to pool their interests with the common run of fruit-growers. These persons are the ones who find special markets here and there, and they should use special and personal means of disposing of their produce. The more cities there are within a given distance, and the greater the number of transportation lines, the greater are the chances that a man will be able to find a personal and special market for his produce.

A $n$ illustration of a fruit market.-A knowledge of the destination of fruit after it reaches a 
metropolis should aid growers and shippers in comprehending the needs of the market. The following is a graphic description of fruit-selling in Chicago:*

"The distribution of the supplies furnished by the fruit-grower, whether direct or through the ageney of others, has gradually become a complex and complete system. Perhaps I ought not to use the term 'complex,' as each step is well defined and, after all, simple, but I think but few fruitgrowers have any idea of how complete it is, and to what distances fruit is exported,-the only limit being the cost and ability of the consumer to pay prices commensurate with the expenses and risks.

"Practically all receipts are taken from the depots or docks to the various places of business as early as practicable after the arrival of the train or steamer. To make the matter clearer, let us illustrate by using letters in place of names. A, a shipper, consigns to $\mathrm{B}$, his correspondent, a shipment of fruit. On arrival, B has his spring wagons in waiting, and takes it to his place of business on South Water street. There, with other lots of fruit of different grades, qualities and conditions, it is examined and offered for sale. The largest, finest, and every-way-select lots are taken by the retail grocers whose patronage is among the 'upper ten,' to whom money is no object, apparently. The grade must be of the very best, quality superior and condition perfect. Less than 5 per cent of the total

* Mr. Barnett, of Barnett Bros., before Mich. Hort. Soc., Dec., 1896, as reported in the Horticultural Gazette, Allegan, Mich., for Dee. 19, 1896. 
receipts meets the conditions exacted, so that the amount that can be disposed of to this class of buyers is limited, and their requirements are also about in the same proportion.

"The next grade is of really good quality and good condition, so that it can be handled with a reasonable degree of safety, and good for, say, twenty-four hours' transit to other points, or to be handled safely by the average retail grocer who supplies the well-to-do classes. The competition for this class of fruit is the greatest, and often a sale turns on the condition only, the shipper often turning from a good line of fruit and accepting something not so desirable in quality, to secure that which will reach his customers in good condition. It is very much better to have a medium grade of quality in good condition than a fancy line of fruit as to flavor, size, etc., worthless on account of decay. That fruit which lacks the carrying qualities desired by the shipper is just right for the retail dealer, and, as a rule, will class good to choice.

"There are then left the inferior grades, both as to quality and condition. For these, buyers are found among the grocery keepers in the poorer sections of the city,-among the foreign populations. They are good judges of fruit, and buy to meet the wants of their customers. With them, also, there are the peddlers, a numerous class and an influential one, whose trade is necessary in handling large receipts. These latter also use the refuse, the 'off condition' of all grades, and the poorest qualities 
that arrive, or that beeome in poor eondition after arrival, as well as a respectable portion of the better grades, for they sometimes carry a very good quality.

"Let us trace these different elasses a little further, bearing in mind earefully that there is no arbitrary grading, the perishable qualities of fruit at times making the 'faney' of $5 \mathrm{~A}$. M. the 'peddler's. stoek' at 5 P. M. Let us suppose C is a retail dealer having the best patronage. He seleets what he needs (earefully paying no more than he can help-which remark also applies to all), has it set aside, and sends his wagon for it as soon as he has eompleted his purehases. Arriving at his store, the fruit is temptingly displayed to eateh the eye, and from his stoek he fills his orders, taken often without the price being named in advance, quality being the ehief requirement, sends to his customer, and charges it up to his aceount. The transaction is completed-all but collecting the bill. Many pay: many do not, and during the last thirty years, of all I have known, in the strietly fancy trade, less than a dozen have earned a competence. But little net profit remains with them.

"The retail dealer, D, who supplies the middle elasses, with a fair proportion of the well-to-do, loads his purehase into his wagon, and at once goes home to be ready for dinner, placing a moderate advanee on his purehase price as his selling figure. He sells for cash if he ean, or to his 'book' eustomers at praetieally the same figure. He delivers to his customer's home, if desired, but the bulk of 
it is taken at the time of purchase, and he clears out his stock as closely as possible. The advance charged by the retailer for his labor of selecting, selling, delivering, and collecting his accounts may be roughly estimated at 2 cents per box on snall fruits, and 2 cents per basket on peaches and 5 cents per peck on apples. This must cover the loss by decay, sampling, etc., inevitable to the retail trade. At times, when fruit is scarce, the profit charged will be larger, and when abundant, less. Sometimes a 'run' is made, and a single dealer will buy one hundred to three hundred baskets and sell at cost, but I consider this as advertising.

"E, the peddler or huckster, buys everything left. It may be 'fancy,' or 'good,' 'out of condition,' 'scrubs,' 'trash'-anything is grist for his mill. With equipments, worth ten dollars for horse, wagon, and harness of the Greek beginner, up through the various grades to the splendid two-horse team and $\$ 200$ wagon (carrying supplies of all kinds and manned by three active, enterprising men) of the successful huckster, the 2,500 members of that great division of distributors are powerful factors. Taking their purchases into their wagons, they at once start for their routes and cry their wares. There can be no fixed margin. They get what they can, take a margin, or sell at cost; live on the refuse, and probably have only a dollar per day on which to support a family. While their transactions on the whole are enormous, their profits are very small, and with long hours, penetrating every street and lane of the 
eity, they earn what they get. There is not a lane, street, nor avenue of the city where their voice is not heard, not a block but is visited by their ramshackled old wagon, their apology for a horse with his harness or straps and strings. Not a house is passed unnoticed; they are everywhere, and sell the fruit at a margin so close that, as I have said, their profits are exceedingly small. I honor them, for they are engaged in an honest ealling; I respect them, for they bring to the very poor, in the poorest sections of the city, a taste, at least, of the richest and best offering of the country to the city, and we use them freely in our business and treat them, rough, uncouth, ragged and ignorant though they may be, as men.

"There remains $\mathrm{F}$, the shipper, whose aid is valuable in the disposition of the receipts from day to day. His selections have been made on the basis of his orders in hand or in prospect. He has carefully studied the country that can be reached from this eity, and by a course of correspondence or personal interview has built up a clientage that orders from him in such quantities as may be sold profitably. The entire northwest has been carefully studied, and from central Illinois to middle Missomri, western Iowa, central Minnesota, and all of Wisconsin, orders have been solicited and some have been received. Weekly quotations are sent, some houses sending two thousand to three thousand at a single issue. These reach every eity, town, village, or hamlet within reasonable rail communication, and everything else is 
out of the question. He studies the needs of each customer, and having secured the amount needed to fill his orders, at once commences to send by express, and to many points where through freights run the fruit goes largely in that manner. It is safe to say that there is no spot within two hundred miles of Chicago that, with fair means of connection with this market, can not have a full supply of fruit. "Now, as to the expense or cost of these shipments. The broker, dealer or shipper is well satisfied if he can realize 10 per cent on his purchases. Let the shipper of fruit to this market consider what it means. There is the eareful selection of fruit, the marking, billing, practically guaranteeing of safe delivery, chances of failure of his far-off customerand collecting his bill at the end of two weeks to three months. Applying the test to the fruit broker or shipper, but few get much more than a living out of the business. The express and freight companies charge only a fair compensation for the service performed. Although fruit may come high in central Minnesota or northern Wisconsin, the dwellers in those regions can not reasonably expect to have fruit brought to them without labor and expense," 


\section{APPENDIX.}

\section{HOW DID THE VARIETIES OF FRUITS ORIGINATE?}

There is universal curiosity to know how the various kinds of fruits have originated. It seems to be next to impossible to enlighten the public mind upon the question, for whatever detailed explanation one may give seems to leave the questioner unsatisfied. The real cause of this dissatisfaction is the fact that people assume that there is something mysterious about the process of the origination of varieties; and so long as the mind makes a mystery of a subject it is impossible to elucidate it. We have also been taught that like normally produces like, and therefore that any unlikeness between two plants-as between the parent and its offspring-calls for instant explanation. The fact is, that it is not the nature of domestic productions for like to produce like, but rather for similar to produce similar. That is, there are certain type or family characteristics which pass over to the offspring, but there is normally almost endless unlikenesses in the details. Apples give rise to apples, and sometimes there is a closer reproduction of the parents in tribes like the Fameuse apples and the Crawford peaches; but there is seldom or never an exact duplication of parental features. Considering that this is the normal law of nature, it follows that the wonder is that plants should ever reproduce the variety with approximate exactness. In other words, rigidity of generation may be the thing to be explained rather than the elas. ticity of it. In kitchen-garden vegetables this rigidity has come about, but it is the direct result of a long effort at selection and breeding until the elasticity of the type has been largely bred out.*

*A fuller explanation of this class of facts will be found on pages 88, 89 and 90 of "Plant-Breeding;" and the reader is referred to that work and to "The Survival of the Unlike" for discussions of the philosophy of plant-breeding and of the running out of varieties. 
Those persons who are always wondering how the varieties of fruits have come should consult the records. History is capable of enlightening them. If the origins of varieties are traced it will be found that in the vast majority of cases the variety was simply discovered, and that some one began to propagate it because he thought it to be good. A tree springs up along a roadside, in the fence-row, back of the barn, in a thicket, and bears acceptable fruit. It is the product of a chance seed dropped by a bird or thrown there by an urchin. A thousand, perhaps ten thousand, seeds produce trees which bear poor or indifferent products where only one bears superior fruit. This one good tree is cherished, and all the others are forgotten, or perhaps are never seen; and then we wonder why so many more good varieties originate in the half-wild places than in the garden. It is only because more seeds have been sown there; and as we do not covet the ground, the failures pass unnoticed. If we should secure the same results in the garden by the sowing of only half the number of seeds, we should consider the experiment to be a costly one. It is probable that a seed will produce the same character of fruit, whether the tree springs up in a fence-row or in the garden; and the halfwild areas are, therefore, most useful and prolific places in which to allow nature to carry out her various whims in plant-breeding. And if man has been willing to be relieved of all effort in the matter, it is fair to assume that he will long continue of the same mind, and that this exploration for new varieties will be a passion of the adventurer until every copse and tangle has been razed into cultivated fields.

There has been, to be sure, an occasional direct attempt to produce new varieties, but there has been very little definite plant. breeding of the type which sets an ideal before the mind and then tries to attain to it. It is not germane to the present book to discuss the fundamental reasons why plants vary and new forms arise. These reasons are obscure at best, but the greater part of them are probably not past finding out. It is enough for this occasion to say that nearly all the varieties of fruits were seedlings found in some waste place, or in a nursery row or a garden; and they were propagated. 


\section{REMARKS ON CLASSIFYING AND DESCRIBING FRUITS.}

We name the varieties of fruits in order that we may speak and write about them. Since the name is a definite thing, it is commonly assumed that the variety is also a definite thing. It is a fact, however, that varieties are not definite or definable. This follows from two facts, - that there is no original or necessary standard or measure of what shall constitute a variety, and that the variety may vary or change through the influence of climate or other agencies. There cre, therefore, varieties representing all degrees of differences, some being so unlike all others as to be universally accepted as distinct, and some so like others as to canse dispute as to whether they are really rarieties or not. Again, we must not assume, because one name has been retained for a certain stock, that the stock, therefore, remains the same. For example, the fact that we still use the name Catawba does not prore that the Catawba grape is the same now as it was when first named and disseminated; the King is not the same apple in Oregon and New York, although the name is the same in both states, and all the trees have been propagated from one original.

These remarks are made for the purpose of pointing out the facts that the classifying and describing of varieties involve two classes of problems,-the questions connected with the making of the names and the systems (as the form of the name, rules of priority. schemes of classification), and those associated with the natural history of varieties (as to whether given varieties are distinet, the value of geographical names and synonyms, and the like). The practical application of these remarks is, that we are not to expect uniform exactness, either in the classifying of varieties or in the describing of them. We can deal only with types, expecting that numerous exceptions will be found to the most painstaking description, and to the most carefully made key. Varieties are not entities or things, as machines are, a fact which, though usually not recognized, has been the reason for the failnre of the many attempts to protect the originator of varieties by means of patent rights.

The first step in making a sketch of a variety is to distinguish clearly between a description and a characterization. A description gives a full account of all the attributes; a characterization gives only those attributes which are unique to the variety. For example, ten kinds of cherries may be large, red and heart-shaped; in descriptions, these three attributes are repeated for each variety; but in 
characterizations, these attributes are omitted (having previously been given in a general sentence), and only those features are mentioned which distinguish any variety from the other nine. It follows that when varieties are arranged alphabetically, only deseriptions are of value; but when they are arranged in some system of classification, only characterizations are admissible. Descriptions are easy to make: one writes down what he sees. Characterizations are difficult to draw: one must make comparisons of many specimens, and he must clearly perceive an ideal type.

In making either descriptions or characterizations, the student should consider the entire plant as well as the fruit itself. The habit of growth, the bark and foliage, the flowers, often have characteristic features in different varieties. Yet, since the fruit is the main consideration, and since the enquirer can seldom have flowers and fruits at the same time, and often has not even access to the plant, it must follow that characters drawn from the fruit itself must form the foundation of the characterization; and these should usually precede other characters in the paragraph. Similarly, a system of classification of the varieties of any fruit which gives great emphasis to characters not drawn from the fruit itself, is fundamentally weak. It is to be expected, therefore, for example, that the effort to classify varieties of apples and pears by characters of the stamens and styles will never come into popular use; but these characters are no doubt of great value if they can be used as secondary features of descriptions or characterizations. For studies of the characters of stamens and styles in pomaceous fruits, see Beal's various writings. (Rep. Mich. Pom. Soc. 1876, 17. Am. Pom. Soc. 1877; 1879, 27; 1881, 73.) Of ideals of classification founded on the characters of the fruit, one of the best discussions is to be found in Hogg's "Fruit Manual" (English). The student should also consult Warder on "The Apple," and Thomas' "American Fruit Culturist."

Since each fruit demands a separate and usually distinct mode of classification and characterization, the details of the subjects cannot be considered here; but the following extracts will show what constitutes a complete and good description in the mind of one careful student (Beal, Proc. 12th and 13th Ann. Meetings Soc. Prom. Agric. Sci., 1892, pp. 25, 28):

"Crescent Strawberry.-Plant rather large, not robust, soft pubescent, of a light green color, very hardy and vigorous and exceedingly productive; runners rather slender, bracts a little above the middle; leaflets slightly involute-conduplicate, oval, coarsely serrate or rarely 
donbly serrate; peduncle rather stout, raising the panicle nearly as high as the leaves; panicle 2-4 inches long, 12-24-flowered (usually about 15-flowered); lower bracts broad, oval; sepals lanceolate or ovate-lanceolate, the alternating bractlets about the same length; petals orbicular, or oval, 4-16 to 5-16 inches long, including a short claw; stamens numerous and well developed; fruit bright erimson, broad ovoid to round oblong, $7 / 8$ inch long; moderately firm; quality, medium; season medium.

"Origin, Connecticut, 1870.

"Probably not excelled by any variety for its productiveness on all sorts of soils and with every kind of treatment. Extensively grown."

"Cuthbert Raspberry.-Plant tall, stout, slightly glaucous, prickles recurved, few, weak, seldom more than one $\mathrm{mm}$. long; leaves, somewhat wrinkled, light green above, light green to glaucous green below, under a lens more or less tomentose; leaflets large, doubly serrate-dentate, often recurved, those on stout shoots mostly five, sessile, puckered at the base, those of bearing branches three, stipules $45 \mathrm{~mm}$. long, erect, terete, 7-10 of the upper leaves bearing 1-4 flowers, light red on the upper side, pedicles $1.5-2.5 \mathrm{~cm}$. long (the whole panicle 20-30 $\mathrm{cm}$. long), smooth or with minute prickles, bractlets 1-2 mm. long; calyx destitute of prickles, petals narrowly oval or obovate, 4-5 mm. long, including the very short claw; pistils clothed with minute reddish pubescence; fruit ovoid-conic, 6-8 mm. long; base of calyx 3-5 mm. long; styles, when dead, brown, bent, $2.5 \mathrm{~mm}$. long; torus conical, $8 \mathrm{~mm}$. long, fruit red, very large and firm, productive and vigorous, quality good, rather hardy, season medium.

"Origin, New Jersey or New York, 1870."

A glossary of some of the leading terms used in describing fruits may be useful to the novice. Of general terms, the following may be mentioned: Phytography, the describing of plants; taxonomy, the science or practice of classification; terminology, the knowledge of the terms or technical words used in any subject; nomenclature, the knowledge of the names used to designate any class of objects.

Leading terms used to designate the shape of fruits are as follows: Conical, length equal to or greater than the breadth and the upper shoulders narrowed (Fig. 115); ovate, broader than the conical (Fig. 116); obovate, inversely ovate (larger at the apex); oblong, length equal to or greater than the breadth, and sides parallel or very nearly so; oblate, distinctly flattened endwise (Fig. 117); lop-sided (Fig. 118). Combinations of these terms with themselves (Fig. 119), 


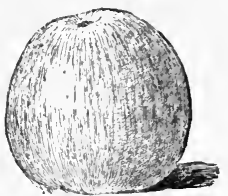

Fig. 115. Conical.

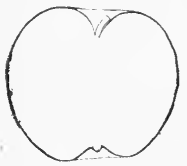

Fig. 116. Ovate.

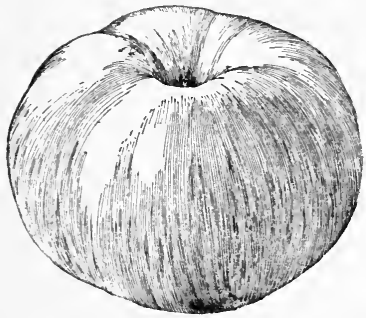

Fig. 117. Oblate.

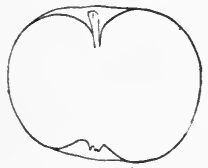

Fig. 118. Lop-sided.

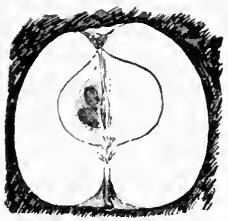

Fig. 119. Oblong-conieal.

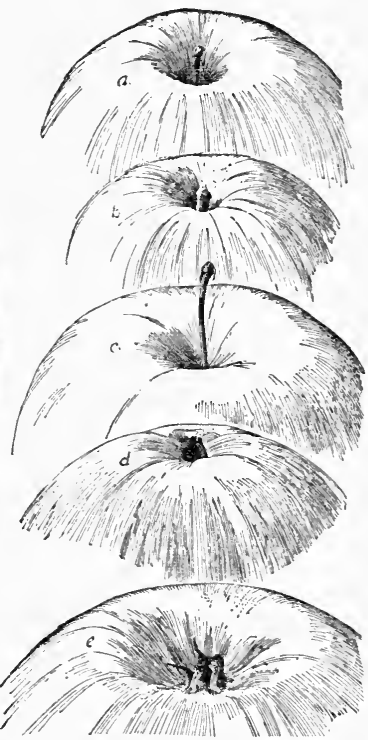

Fig. 120. Various types. 
and with such common adjectives as spherical, round, short, flat, enable one to designate the form of the more irregular fruits.

The ends or extremities of fruits are described by technical terms. In pome-like fruits, the depression in the apex (or blossom end) is known as the basin (d, e, Fig. 120). The depression at the base (or stem end) is the cavity (a, b, c, Fig. 120). The basin is broad and deep in $e$, and small and shallow in $d$; and it is corrugated or furrowed in Fig. 117. The cavity is narrow and deep in a, broad and deep in $c$, and narrow and shallow in $b$. In the basin sits the calyx or eye. This calyx is open in $e$, and closed in $d$. The statk or stem is short in a, very short in $b$, and long and slender in $c$. In stonefruits, the depressions at apex and base are less marked, and the term basin is not used; but carity is used for the depression about the stem. The longitudinal furrow or depression on the side of a stone-fruit (as of a peach or plum) is known as a suture.

In describing the color of a fruit, it is customary to assume an under-color or ground-color, which is laid on nearly or quite uniformly over the entire surface, and over which the markings are dis played. This ground-color is therefore the prevailing tone of yellow or green, or other subdued color, which shows between the spots and streaks, underneath the solid red or purple, and on the uncolored side of the fruit. A fruit is striped when it is marked by broad and more or less definite longitudinal bands; streaked when the markings are very narrow, as in Fig. 115; splashed when the stripes are broken and irregular; mottled when marked by large confluent dots.

The quality of a fruit is determined by its texture and its flavor. The texture is said to be hard, coarse, gritty, rough, fine-grained, buttery, melting. The flavor is described as poor, good, very good (largely matters of individual taste), sweet, acid or sour, subacid or sourish (that is, only slightly sour), dry, juicy, vinous (with a lively wine-like suggestion), aromatic, and the like.

The names of rarieties should be short and modest; and a name which has once been used should not be used again in the same elass of fruit, eren though the variety to which it was first applied should hare become extinct. All titles, as General, Professor, President, and all extravagant adjectives, as superb, magnificent, grand, should be omitted from the name of the rariety. The standard practice in this country is that specified in the rules adopted by the American Pomological Society. Helpful suggestions may also be found in the rules adopted by a committee of horticulturists for the naming of vegetables, and published in "Annals of Horticulture for 1889." 


\section{AMERICAN BOOKS ON FRUIT-GROWING.}

The subjoined bibliography comprises all the American books in the author's library which are devoted to the general discussion of fruit-growing. It omits all works upon particular pomological topies, as small-fruits, grapes, oranges, and the like. Inventories of these special books belong properly in the works which shall be devoted to the various classes of fruits.

BAILEY, L. H.

Garden-Making. Suggestions for the utilizing of home grounds. Aided by L. R. Taft, F. A. Waugh, Ernest Walker. New York and London. 1898. [c. 1898.*] The Macmillan Company. pp. vii +417. $7 \times 5+$. [The Garden-Craft Series.]

-Same. Reprinted 1898. pp. vii +417 .

- Same, 3rd ed., revised. pp. vii +417 .

BAILEY, L. H.

The Nursery-Book; a complete guide to the multiplication and pollination of plants. Illustrated. New York. 1891. [c. 1891.] The Rural Publishing Company. pp. 304. $71 / 2 \times 51 / 2$.

-Same, 3rd ed. New York and London. 1896. [c. 1896.] The Macmillan Company. pp. xi +365 . $7 \times 4 \frac{1}{2}$. [The Garden-Craft Series.]

- Same, 4th ed. 1900. pp. $x i+365$.

BAILEY, L. H.

The Principles of Fruit-Growing. Illustrated. New York and London. 1897. [c. 1897.] The Macmillan Company. pp. $x i+508$. $7 \times 43 / 4$. [The Rural Science Series.]

-Same, 2nd edition. 1898. pp. xvii +514 .

BAILEY, L. H.

The PRUNing-Book. A monograph of the pruning and training of plants as applied to American conditions. Illustrated. New York and London. 1898. [c. 1898.] The Macmillan Company, pp. ix +537. $7 \times 5$. [The Garden-Craft Series.]

-Same, 2nd ed. 1899. pp. ix +545 .

* Date of copyright.

t Length and width of volume, in inches. 
BAKER, CHARLES R.

Practical and Scientific Fruit-Culture. Illustrated. Boston. 1866. [c. 1866.] Lee \& Shepard. pp. 523. $81 / 4 \times 5 \frac{1}{2}$.

BARRY, P.

The Frut Garden; a treatise intended to explain and illustrate the physiology of fruit trees, the theory and practice of all operations connected with the propagation, transplanting, pruning and training of orchard and garden trees, as standards, dwarfs, pyramids, espaliers, etc., the laying out and arranging different kinds of orchards and gardens, the selection of suitable varieties for different purposes and localities, gathering and preserving fruits, treatment of diseases, destruction of insects, descriptions and uses of implements, etc. Illustrated with upwards of 150 figures, representing different parts of trees, all practical operations, forms of trees, designs for plantations, implements, etc. New York. 1860. [c. 1851.] C. M. Saxton, Barker \& Co. pp. $x i v+398$. $7 \frac{1}{2} \times 5$.

-Same. New edition. Revised and brought down to date, by the author. Illustrated. New York. 1888. [c. 1883.] Orange Judd Company. pp. $\mathrm{x} v \mathrm{i}+516$. $73 / 4 \times 5$.

BEADLE, D. W.

Canadian Fruit, Flower, and Kitchen Gardener; a guide in all matters relating to the cultivation of fruits, flowers and vegetables, and their value for cultivation in this climate. Illustrated. Colored plates. Toronto. 1872. [c. 1872.] James Campbell \& Son. pp. xvi+391. $9 \times 6$.

BEECHER, HENRY WARD.

Plain and Pleasant Talk about Fruits, Flowers and Farming. New York. 1859. [c. 1859]. Derby \& Jackson. A. O. Moore \& Co. pp. viii +420 . $71 / 2+5$.

-Same, new edition, with additional matter from recent writings, published and unpublished. New York. 1874. [c. 1873.] J. B. Ford \& Co. pp. vii +498 . $73 / 4 \times 5$.

BRÉHAUT, REV. T. COLLINGS.

Cordon Training of Fruit Trees; diagonal, vertical, spiral, horizontal, adapted to the orchard-house and open-air culture. With a supplement containing remarks on cordon training, the cultivation and pruning of peach trees in pots, the best varieties of 
fruits for pot-culture; and general remarks on orchard-houses adapted to the climate of the United States. By C. M. Hovey. lllustrated. Boston. 1864. [n. c.] Hovey \& Co. pp. 112. $9 \times 53 / 4$. [The supplement, pp. 79-112, is by Hovey.]

\section{BRIDGEMAN, THOMAS.}

The Frute-Cultivator's Mandal; containing ample directions for the eultivation of the most important fruits, including the cranberry, the fig, and grape, with descriptive lists of the most admired varieties. And a calendar, showing the work necessary to be done in the orchard and fruit-garden every month of the year. The whole adapted to the climate of the [nited States. Portrait. New York. 1845. [c. 1844.] A. Hanford. pp. rit 175. $7 \frac{1}{2} \times 4 \frac{1}{2}$.

-Same. New York. 1847. [c. 1847.] pp. ri + 189. $71 \frac{1}{2} \times 4 \frac{1}{2}$.

BRINCKLE, WILLIAM D., Editor.

Hoffy's North AMErican Pomologist; containing numerous finely colored drawings, accompanied by letter press descriptions. etc., of fruits of American origin. Portrait. Book No. I. Philadelphia. 1860. [c. 1860.] Prepared and published by A. Hoffy. pp. vi+44. $103 / 4 \times 8$.

COLE, S. W.

The American Fruti-Book; containing directions for raising, propagating, and managing fruit-trees, shrubs, and plants; with a description of the best rarieties of fruit, including new and valuable kinds; embellished and illustrated with numerous engravings of fruits, trees, insects, grafting, budding, training, etc., ete. Eighteenth thousand. Boston. 1850. [n. c.] John P. Jewett $\&$ Co.; New York. C. M. Saxton. pp. 288 . $6 \times 4$.

COLLINGWOOD, H. W.

Fertilizers and Fruit. A trip among growers in the famous Hudson River fruit district. Best quality in fruit. New York. 1893. [c. 1893.] The Rural Publishing Co. pp. 27. $7 \frac{1}{2} \times 5$. [The Rural Library, Vol. I., No. 25, Dec.]

COXE, WILLIAM.

A View of the Cultivation of Fruit Trees, and the MaNAGEMENT OF ORChaRdS AND CiDER; with accurate descriptions of the most estimable varieties of native and foreign apples, 
pears, peaches, plums, and cherries, cultivated in the Middle States of America; illustrated by cuts of two hundred kinds of fruits of the natural size; intended to explain some of the errors which exist relative to the origin, popular names, and character of many of our fruits; to identify them by accurate descriptions of their properties, and correct delineations of the full size and natural formation of each variety; and to exhibit a system of practice adapted to our climate, in the successive stages of a nursery, orchard, and cider establishment. Philadelphia. 1817. [c. 1817.] Published by M. Carey \& Son. D. Allinson, printer. pp. iv +268 . $83 / 4 \times 51 / 2$.

CREIGHTON, W. O.

F'́ult-Growing for Profit; comprising a complete history of apple culture, from the time the seeds are planted until the proceeds are pocketed. With chapters on the plum, pear, cherry, strawberry, raspberry, blackberry, currant and gooseberry. Halifax, N. S. 1891. [n. c.] Nova Scotia Printing Co. pp. 52. $81 / 2 \times 51 / 2$.

DOWNING, A. J.

The Fruits and Fruit Trees of America; or the culture, propagation, and management, in the garden and orchard, of fruit trees generally; with descriptions of all the finest varieties of fruit, native and foreign, cultivated in this country. Illustrated with many engravings. New York and London. 1845. [c. 1845.] Wiley \& Putnam. pp. xiv $+594.8 \times 5$.

- Same (6th ed.), 1846. [c. 1845.] pp. xiv +594. $8 \times 5$.

- Same (7th ed.), 1847. [c. 1845.] pp. xiv +594. $8 \times 5$.

- Same [with wide margin and colored plates]. 1847. [c. 1845.] pp. $x i v+594.10 \times 61 / 4$.

- Same (9th ed.) 1849. [c. 1845.] John Wiley. pp. xiv +594 . $8 \times 5$.

-Same, revised and corrected by Charles Downing. 1860. [c. 1857]. John Wiley. pp. xiii +760 . $8 \times 5$.

- Same, 1864. [c. 1857.] pp. xix +760. $8 \times 5$.

- Same, second revision and correction, with large additions, ineluding the appendices of 1872 to 1881 , and containing many new varieties, by Charles Downing, with nearly 400 outline illustrations of fruit. 1890. [c. 1872.] John Wiley \& Sons. pp. $\mathrm{xxiv}+1,098+\mathrm{ix}+189.91 / 2 \times 6$.

- Same, appendices I., II., III. 1881. [c. 1881.] pp. $x i i+189$. $9 \times 5 \frac{3}{4}$. 
DOWNING, CHARLES.

Selected Frults; from Downing's Fruits and Fruit-Trees of America. With some new varietics; ineluding their culture, propagation, and management in the garden and orchard. Illustrated with upwards of four hundred outlines of apples, cherries, grapes, plums, pears, etc. New York. 1871. [c. 1871.] John Wiley \& Son. pp. $x+679.8 \times 5 \frac{1}{2}$.

- Same, fifth edition. 1845. [c. 1845.] pp. xiv +594. $8 \times 5$.

ELLIOTT, F. R.

Fruit Book; or, the Ameriean fruit-grower's guide in orchard and garden. Being a eompend of the history, modes of propagation, culture, ete., of fruit trees and shrubs, with deseriptions of nearly all the varieties of fruits cultivated in this country; notes of their adaptation to localities and soils, and also a complete list of fruits worthy of cultivation. Illustrated. New York. 1854. [e. 1854]. C. M. Saxton. pp. ix +503 . $8 \times 5$.

-Same, The Western Fruit-Book; new edition, revised, enlarged and improved. New York. n. d. [c. 1859.] Orange Judd Co. pp. $x i+528.7 \frac{1}{2} \times 5$.

ELLIOTT, F. R.

HAND-BOOK FOR FrUtT-Growers; containing a short history of fruits and their value, instructions as to soils and locations, how to grow from seeds, how to bud and graft, the making of euttings, pruning, best age for transplanting, etc., etc. With a list of varieties suited to climate. Illustrated. Made for those who grow fruit for their own use. New edition, enlarged. Rochester. [c. 1876.] Rochester Lithographing Co. No date. pp. 144. $7 \times 5 \frac{1}{4}$.

ELLIOTT, WILLIAM R.

Practical and Comprehensive Treatise on Fruit and Floral Culture, and a few hints on landseape gardening. Illustrated. n. d. [Philadelphia alvertisements interspersed.] pp. 100. $7 \times 4 \frac{1}{2}$.

EMMONS, EBENEZER.

Agriculture of NEw York; comprising an aecount of the classification, composition and distribution of the soils and rocks, and the natural waters of the different geologieal formations; together with a condensed view of the elimate and the agricultural produetions of the state. Nlany eolored plates. Vol. III [comprising an aeeount of the fruits]. Albany. 1851. pp. viiit340. 11 x9. [In Natural History of New York.] 
FORSYTH, WILLIAM.

An Epitome of Mr. Forsyth's Treatise on the Culture and Management of Fruit Trees. Also, notes on American gardening and fruits; with designs for promoting the ripening of fruits and securing them as family comforts; and further, of economical principles in building farmers' habitations. By an American farmer. Philadelphia. 1803. [n. c.] Printed by T. L. Plowman for John Morgan. pp. $186+6$. $81 / 2 \times 51 / 4$.

FORSYTH, WILLIAM.

A Treatise on the Culture and Management of Fruit Trees; in which a new method of pruning and training is fully described. Together with observations on the diseases, defects, "and injuries in all kinds of fruit and forest trees; as also, an account of a particular method of cure, made public by order of the British government. To which are added an introduction and notes, adapting the rules of the treatise to the climate and seasons of the United States of America. By William Cobbett. Plate. New York. 1802. [n. c.] Ezra Sargeant \& Co. pp. viii +259 . $81 / 2 \times 51 / 4$.

-Same. Albany. 1803. [n. c.] D. \& S. Whiting. pp. xii +280 . $81 / 4 \times 5 \frac{1}{4}$. Contains at the close a commendatory letter from Peter W. Yates, of Albany.

FULLER, ANDREW S.

The Propagation of Plants; giving the principles which govern the development and growth of plants, their botanical affinities and peculiar properties; also, deseriptions of the process by which varieties and species are crossed or hybridized, and the many different methods by which cultivated plants may be propagated and multiplied. Illustrated with numerous engrarings. New York. 1887. [c. 1887.] Orange Judd Co., David W. Judd, president. pp. $\mathrm{x}+349.71 / 2 \times 5$.

GOODRICH, CHAUNCEY.

The Northers Fruit Culturist; or, the farmer's guide to the orchard and fruit garden. Illustrated. Burlington. 1849. [c. 1849.] Chauncey Goodrich. pp. viiit 108. $7 \frac{1}{2} \times 4 \frac{1}{2}$.

-Same, second edition, corrected and enlarged. Burlington. 1850. [c. 1849.] Chauncey Goodrich. pp. viii+112. $71 / 2 \times 4 \frac{1}{2}$.

GREEN, CHARLES A.

Green's Four Books, devoted to: 1. How we made the old farm pay. 2. Peach culture. 3. How to propagate fruit-plants, vines and trees. 4. General fruit instructor. Illustrated. 
Rochester, N. Y. 1897. [e. 1895.] Green's Nursery Co. pp. 119. $9 \times 6$. [New edition of 1897.]

GREEN, CHARLES A.

Green's Six Books, devoted to apple culture, pear culture, plum and cherry culture, raspberry and blackberry culture, grape culture, strawberry, eurrant, gooseberry and persimmon culture. Illustrated. Rochester, N. Y. 1896. [c. 1894.] Green's Nursery Co., N. Y. pp. 142, $9 \times 6$. [New edition of 1896.]

GREEN, CHARLES A.

How to Propagate and Grow Fruit; editor of Green's Fruit Grover. Two colored plates. Over fifty illustrations. Rochester, N. Y. n. d. [c. 1885.] pp. $80.91 / 4 \times 6$.

GREEN, SAMUEL B.

Amateur Frutt Growing; a practical guide to the growing of fruit for home use and the market. Written with special reference to colder climates. Illustrated. Minneapolis. 1894. [c. 1893.] Farm, Stock and Home Publishing Co. pp. 132. 71/2 x 5 . GREGG, THOMAS.

A Hand-Book of FrutT-Culture; being a guide to the cultivation and management of fruit trees; with condensed descriptions of many of the best and most popular varieties in the United States. Illustrated with ninety engravings. With an appendix containing a variety of useful memoranda on the subject, valuable household receipts, ete. N. Y. n. d. [c. 1857.] Fowler \& Wells. pp. viii+163. $7 \frac{1}{2} \times 4 \frac{1}{2}$.

GURNEY, C. W.

Northwestern Pomology; a treatise on the growing and care of trees, fruits and flowers in the northwestern states. Concord, Nebraska. 1894. [c. 1894.] Pub. by Author. pp. 293. $8 \times 5 \frac{1}{4}$.

HARCOURT, HELEN.

Flokida Fruits, and How to Raise Them. Revised and enlarged edition, with elaborate index of subjects. Louisville, Ky. 1866. [e. 1866.] John P. Morton \& Co. pp. 347. $8 \times 5 \frac{1}{4}$. HOOPER, E. J.

Hooper's Western FrutT-BOoK; a compendious collection of facts, from the notes and experience of successful fruit culturists, arranged for practical use in the orchard and garden. Colored plates. Cincinnati. 1857. [e. 1857.] Moore, Wilstach, Keys \& Co. pp. $\mathrm{x}+333.8 \times 5$.

-Same, 3rd edition, completely revised. 1858. [c. 1857.] pp. $x+355.8 \times 5$. 


\section{Appendix.}

HOVEY, C. M.

The Fruits of AMERICA; containing richly colored figures, and full descriptions of all the choicest varieties cultivated in the United States. Boston. Vol. I., Hovey \& Co. 1852. [c. 1851.] pp. 100. Vol. II., Hovey \& Co. 1856. [c. 1851.] pp. 96 . $11 \frac{1}{2} \times 8$. [In Cornell Univ. Library, Vol. II. has 24 pp. of Vol. III., but no title. Vol. III. was never completed.]

HOW to Grow Fruit, Flowers and Vegetables; and the language of flowers. New York. Norman L. Munro. No date. Paper. pp. $68.61 / 2 \times 4$.

IVES, JOHN M.

See Manning, Robert. The New England Fruit-Book. JAQUUES, GEORGE.

A Practical Treatise on the Management of Fruit Trees; with descriptive lists of the most valuable fruits for general cultivation; adapted to the interior of New England. Worcester. 1849. [e. 1849.] Erastus N. Tucker. pp. 256. 68/4 $\times 41 \frac{1}{2}$. [Bound as Jaques' N. E. Fruit Trees.]

JENKINS, J.

ARt of Propagation; a hand-book for nurserymen, florists, gardeners, and everybody. Illustrated."Winona, Columbia Co., Ohio. 1886. [c. 1876.] Jenkins' Gŕape and Seedling Nursery. pp. 31. $9 \times 6$.

KENRICK, WILLIAM.

The New AMERICAN ORCHARDist; or, an account of the most valuable varieties of fruit, adapted to cultivation in the climate of the United States, from the latitude of $25^{\circ}$ to $54^{\circ}$, with their uses, modes of culture, and management; remedies for the maladies to which they are subject, from noxious insects, and other causes, ete. Also, a brief description of the most ornamental forest trees, shrubs, flowers, etc. Boston. 1833. [c. 1832.] Carter, Kendel \& Co., and Russell, Odiorne \& Co. pp. xxxvi+428. $71 / 2 \times 43 / 4$.

KENRICK, WILLIAM.

The New American Orchardist; or, an account of the most valuable varieties of fruit, of all climates, adapted to cultivation in the United States, with their history, modes of culture, management, uses, etc. And the culture of silk. With an appendix on vegetables, ornamental trees, shrubs and flowers. Second edition, enlarged and improved. Boston. 1835. [c. 1835.] Russell, Odiorne \& Metealf. pp. 418. $7 \frac{1}{2} \times 4 \frac{3}{4}$. 
KENRICK, WILJIAM.

The New American Orchardist; or, an aceonnt of the most valuable varieties of fruit, of all elimates, arlapted to eultivation in the United States; with their history, modes of culture, management, uses, ete. With an aprendix on regetables, ornamental trees, shrubs and flowers, the agricultural resourees of Ameriea, and on silk, ete. Third edition, enlarged and improved. Boston. 1841. [e. 1841.] Otis, Broaders \& Co. pp. 449. $71 / 2 \times 4 \frac{3}{4}$.

-Same, 5th edition, enlarged and improved. 1842. [e. 1841.] pp. 449. $\quad 7 \frac{1}{2} \times 5$.

-Same. 6th edition, enlarged and improved. With a supplement. 1843. [e. 1841.] pp. 450 . $71 / 2 \times 5$.

-Same, 7th edition, enlarged and improved. With a supplement. 1844. [c. 1841.] pp. 450 . $71 / 2 \times 5$.

-Same, 8th edition, enlarged and improved. With a supplement. 1848. [c. 1841.] pp. 450 . $71 / 2 \times 5$.

KITCHEN ANd Frit Gardener, The; a select manual of kitchen gardening, and eulture of fruits, containing familiar directions for the most approved practice in each department, deseriptions of many valuable fruits, and a calendar of work to be performed each month in the year. The whole adapted to the elimate of the United States. Philadelphia. 1844. [c. 1844.] Lea \& Blanchard. pp. $x i i+118$. $73 / 4 \times 43 / 4$. [An American edition of an English work. Bound with the Complete Florist.]

KNOWLTON, D. H.

Frut Celture; its possibilities in Maine. A paper delivered before the winter meeting of the Maine State Pomological Society, held in Bangor, Feb. 24 and 25, 1891. Farmington, Maine. pp. 12. $6 \times 3$. [Separately printed.]

LACY, T. .TAY.

Frcit Cllture for the Gelf States, south of latitude $32^{\circ}$. Alexandria, La. 1888. [c. 1888.] Press of Town Talk. pp. 50. $61 / 2 \times 41 / 4$.

LARSEN, HENRY.

Manual for the Pruning and Culture of All Kinds of Fruit Tress; and directions for the destruction of the eurculio and other inseets. Philadelphia. 1860. [e. 1859.] James Challen \& Son. pp. 75. $6 \times 4$.

LAWSON, WILLIAN.

A New Orchard and Garden; or, the best way for planting, 
grafting, and to make any ground good, for a rich orchard. Particularly in the north, and generally for the whole kingdom of England, as in nature, reason, situation, and all probabilitie, may and doth appeare. With the country housewife's garden for herbs of common use, their vertues, seasons, profits, ornaments, varietie of knots, models for trees, and plots for the best ordering of grounds and walkes. As also the husbandry of bees, with their several uses and annoyances, all being the experiences of 48 years' labour, and now the third time corrected and much enlarged, by William Lawson. Whereunto is newly added the art of propagating plants, with the true ordering of all manner of fruits, in their gathering, carrying home, and preservation. Printed at London by J. H. for Francis Williams. 1626. Illustrated. Philadelphia. 1858. [n. c.] Robert Pearsall Smith. pp. 39. 91/4 x6. [Reprint.]

LINDLEY, GEORGE.

A Guide to the Orchard and Fruit Garden; or, an account of the most valuable fruits cultivated in Great Britian. With additions of all the most valuable fruits cultivated in America, with directions for their cultivation, budding, grafting and propagation, pruning and training of standard, open dwarf and espalier fruit trees, adapted to the climate of the United States of America. A new edition, with an appendix, describing many American fruits not mentioned in the former edition. Illustrated. New York. 1846. [c. 1846.] J. C. Riker. pp. $x i+420$. 71/2 $\times 4 \frac{1}{2}$.

LODEMAN, E. G.

The SPRaying of PlaAnts; a succinct account of the application of liquids and powders to plants for the purpose of destroying insects and fungi. With a preface by B. T. Galloway. Portrait of A. Millardet. Illustrated. New York and London. 1896. [c. 1896.] Macmillan \& Co. pp. xvii +399. 7x 5. [The Rural Science Series, edited by L. H. Bailey.]

MANNING, ROBERT.

Book of Fruits; being a descriptive catalogue of the most valuable varieties of the pear, apple, peach, plum and cherry, for New England culture. To which is added the gooseberry, currant, raspberry, strawberry, and the grape; with modes of culture. Also, hardy ornamental trees and shrubs. With plates. First series for 1838. Salem. 1838. [c. 1838.] Published by Ives \& Jewett. pp. 120 . $7 \frac{1}{2} \times 43 / 4$. 
MANNING, ROBERT.

The New England Fruit Book; being a descriptive catalogue oi the most valuable varieties of the pear, apple. peach, plum and cherry, for New England culture. To which is added other varieties; also the grape, quince, gooseberry, currant, and strawberry; with outlines of many of the finest pears, drawn from nature; with directions for pruning, grafting, budding, and general modes of culture. Second edition, enlarged by John M. Ives. Salem and Boston. 1844. [c. 1844.] Pub. by W. \& S. B. Ives, Salem. B. B. Mussey, Boston. pp. 133. $71 / 2 \times 4 \frac{3}{4}$.

MAYNARD, S. T.

The Practical Fruit-Grower. Profusely illustrated. Springfield, Mass. 1898. [c. 1885.] The Phelps Publishing Company, pp. 128. $7 \frac{1}{2} \times 5$.

MCNEIL, J. W.

Fruits and Vegetables. Hazlehurst, Miss. 1888. [n. c.] Copiah Signal print. pp. $21.9 \times 5 \% 4$.

NEILL, PATRICK.

The Fruit, Flower, and Kitchen Garden. Adapted to the United States, from the fourth edition, revised and improved by the author. Illustrated. Philadelphia. 1851. [c. 1851.] Henry Carey Baird. pp. ix $+427.73 / 4 \times 43 / 4$.

NEILL, PATRICK.

The Practical Fruit, Flower and Vegetable Gardener's CoyPAxion, with a calendar; alapted to the United States from the fourth edition, revised and improved by the author. Edited by G. Emerson. With notes and additions by R. G. Pardee. With elegant illustrations. New York. 1858. [c. 1855.] A. O. Moore. pp. $x i v+408$. $71 / 2 \times 51 / 4$.

NUTTING, W. R.

California Views in Natural Colors. The California Illustrated Series. Vol. I., No. 2. San Francisco. April, 1889. [c. 1889.] California View Publishing Co. pp. 30. $7 \times 10 \frac{1}{2}$.

PARKER, S, C., Editor.

Profits and Costs of Fruit-Growing in Nova Scotia. 1893. pp. $16.8 \frac{1}{2} \times 6$.

PEEK, S. W.

The Nurgery aNd Orchard; a practical treatise on fruit culture. Illustrated. Atlanta, Ga. 1885. [c. 1885.] Jas. P. Harrison \& Co. pp. $208 . \quad 73 / 4 \times 5$. 
PHILLIPS, NORMAN.

History of Fruit-Growing in South Haven, Mich. President Phillips' second annual address. [Read before the South Haven Pomological Society, Dec. 30, 1872.]

POOLE, MRS. HESTER M.

Fruits, And How to Use TheM; a practical manual for housekeepers; containing nearly seren hundred recipes for wholesome preparations of foreign and domestic fruits. New York. 1890. [c. 1889.] Fowler \& Wells. pp. 242. $71 / 3 \times 5$.

POWELL, E. C., Editor.

Fruit Packages; the current styles of baskets, boxes, crates and barrels used in marketing fruits in all parts of the country. Fully illustrated. New York. 1893. [c. 1893.] The Rural Publishing Co. pp. 62. $7 \frac{1}{2} \times 5$. [The Rural Library, Vol. I., No. 19. June.]

PRINCE, WILLIAM ROBERT.

The PoMological Mandal; or, a treatise on fruits; containing descriptions of a great number of the most valuable varieties for the orchard and garden. Aided by William Prince. Parts I. and II. New York. 1831. [c. 1831.] T. \& J. Swords, G. \& C. \& H. Carvill, E. Bliss, Collins \& Co., G. Thorburn \& Sons, New York; Judah Dobson, Philadelphia; J. B. Russell, Boston; Gideon B. Smith, Baltimore; James Winston, Richmond; and Joseph Simmons, Charleston, S. C. pp. vi+200, vi+216. $9 \times 5 \frac{1}{2}$. [Parts separately bound.]

-Same, parts I. and II., 2nd edition. 1832. [c. 1831.] pp. $v i+200, x v i+216.9 \times 51 / 2$. [Bound together.]

RIVERS, THOMAS.

The Miniature Froit Garden; or, the culture of pyramidal and bush fruit trees. From the 13th English edition. Illustrated. New York. n. d. Orange Judd Company. pp. $x+133.71 / 2 \times 5$. [Publisher's preface dated 1866.]

-Same. With instructions for root-pruning, etc. 15th edition. Boston. 1870. J. E. Tilton \& Co. pp. $x+156$. 61/2 $\times 4 \frac{1}{2}$. [Printed from the English plates.]

SAYERS, E.

The American Frutt Garden Companion; being a practical treatise on the propagation and culture of fruit, adapted to the Northern and Middle States. Boston. 1839. [c. 1838.] Weeks, Jordan \& Co. pp. $x v+174.7 \times 4 \frac{1}{2}$. 
STRONG, W. C.

Frurt Culture; and the laying out and management of a country home. Illustrated. Boston. 1885. [c. 1885.] Houghton, Mifflin \& Co. pp. $\mathrm{v}+202.7 \times 4 \frac{1}{2}$.

-Same, New York. 1892. [c. 1885.] The Rural Publishing Co. pp. $\mathrm{xiv}+231$. $7 \frac{1}{2} \times 5$.

THACHER, JAMES.

The American Orchardist; or, a practical treatise on the culture and management of apple and other fruit trees, with observations on the diseases to which they are liable, and their remedies. To which is added the most approved method of manufacturing and preserving eider, compiled from the latest and most approved authorities, and adapted to the use of American farmers. Boston. 1822. [c. 1822.] Printed and published by Joseph W. Ingraham. pp. vi+226. $9 \times 5 \frac{1}{4}$.

- Same, bound with American Orchardist and Cottage Economy. By William Cobbett.

THACHER, JAMES.

THE AMERICAN ORCHARDIsT; or, a practical treatise on the culture and management of apple and other fruit trees, with observations on the diseases to which they are liable, and their remedies. To which is added the most approved method of manufacturing and preserving cider, and also wine from apple juice and eurrants. Adapted to the use of American farmers, and all lovers and eultivators of fine fruit. Second edition, mueh improved. Plymouth, Mass. 1825. [e. 1825.] Published by Ezra Collier. pp. iv $+234.7 \times 4 \frac{1}{4}$.

THOMAS, JOHN J.

The Aserican Fruit Culturist; containing directions for the propagation and eulture of fruit trees in the nursery, orchard and garden. With deseriptions of the prineipal American and foreign varieties eultivated in the United States. Illustrated with three hundred accurate figures. Fourth edition. Auburn. 1850. [c. 1849.] Derby, Niller \& Co. pp. xiv $+420.73 / 4 \times 5$.

-Same, 1851. [e. 1849.] pp. xiv +410 . $73 / 4 \times 5$.

-Same, Auburn and Buffalo. 1854. [e. 1849.] Miller, Orton \& Mulligan. pp. xiv $+421.73 / 4 \times 5$.

-Same, New York. 1858. [c. 1849.] C. M. Saxton. pp. xiv +424 . $73 / 4 \times 5$. Same also by Miller, Orton \& Mulligan.

-Same. Illustrated with four bundred and eighty accurate figures. New York. 1867. [e. 1867.] William Wood \& Co. pp. vi +511 . $8 \times 5 \frac{1}{4}$. 
THOMAS, JOHN J.

The American Fruit Culturist ; containing practical directions for the propagation and culture of all fruits adapted to the United States. A thoroughly revised edition [8th], illustrated with five hundred and eight accurate figures. Colored frontispiece. New York. 1875. [c. 1885.] William Wood \& Co. pp. $\mathrm{vi}+576.9 \times 61 / 4$.

-Same. A thoroughly revised edition, illustrated with five hundred and nineteen accurate figures. New York. 1885. [c. 18751885]. William Wood \& Co. pp. vi +593. $71 / 2 \times 5$.

-Same, 20th edition, revised and enlarged by William H. S. Wood. Illustrated with nearly eight hundred accurate figures. 1897. [c. 1875, 1885, 1897.] pp. $x \mathrm{v}+758.81 / 4 \times 53 / 4$.

THOMAS, JOHN J.

The Frut Culturist ; adapted to the climate of the northern states; containing directions for raising young trees in the nursery, and for the management of the orchard and fruit garden. Fourth edition. lllustrated. New York. 1847. [c. 1846.] Mark H. Newman \& Co. pp. vi+216. 61/2 $\times 41 \frac{1}{2}$.

WICKSON, EDWARD J.

California lluustrated, No. I. The Vacaville early fruit district of California. Second edition. Colored plates. San Francisco. 1888. [c. 1888.] California View Publishing Co. pp. viii $+149+$ viii. $101 / 4 \times 7$.

WICKSON, EDWARD J.

The California Fruits, and How to Grow Them. A manual of methods which have yielded greatest success; with lists of varieties best adapted to the different districts of the state. First edition. Illustrated. San Francisco. 1889. [c. 1889.] Dewey \& Co. pp. $v i+575$. $9 \times 6$.

-Same. Second edition, revised and enlarged. 1891. [c. 1889.] pp. viii $+599.9 \times 6$.

-Same. 3rd ed., largely rewritten. 1900. [c. 1899.] Pacific Rural Press. pp. viii $+477.9 \times 6$. 



\section{INDEX.}

PAGE

Acers, growth of ....................

Achras ......................... 4

Asculus, growths of..............166

Agents .......................236

Age of trees for planting ........233

Air-enrrents ................... 47

- currents and frost .............119

- heating .......................120

Alabama, frost ..................125

Alcohol as preservative..........458

Alligator pear ................ 5

Almond, kinds of ............... 5

- for wind-breaks ............... 89

- mulching .................... 93

Alnus, growths of.................166

Alternate plan.................267

Altitude and frosts ............. 55

- and zones .................... 9

Alwood, W. B., on storing........452

Amelanchier.................... 6

- growth of .....................166

American Net \& Twine Co.........296

Ammoniacal copper carb ...........369

Ammonia test for Paris green......374

Amorpha, growth of..............166

Ampelopsis, growth of.............166

Anacardiaceous fruits ........... 4

Anacardium ................... 5

Analyses of cover crops ...........201

Ananas ........................ 7

Andrews, W. S., quoted ............114

Aniline dyes .....................416

Anonaceous fruits ............... 4

Anona, species of.............. 4

- zone...................... 8

Anthracnose ....................347
PAGE

Apple and the seab...........347,35t

- culture, status of .............136

- growing, status of.............. 30

- root, broken .................280

- roots.........................161

- soils for...................... 19

- storage-house.................449

- zone........................ 8

Apples, age for planting..........233

- and cedar-apples................ 78

- distance for...............240, 273

- exporting ....................409

- fertilizers in..............203, 205

- grading..................402, 403

- hand-picking.................401

- how to piek ...................385

- injured by cold..................325

- in sod.......................172

- keeping..................380, 397

- packing ......................407

- preserving ...................459

- ringing.....................291

- species of .................... 2

- sterile and fertile...............229

- storing....................437

- temperature for keeping.....444, 450

- thinning.................300,306

- when to pick...................280

- with peaches ..............241, 242

- wrapping ....................413

- trees, and latitude..........243, 265

- - grafting ...................298

- mulching..................93 93

- - trimming young..........251-253

Apricot-culture, status of.........137

- flower injured...............317-321 
Apricots, distance for.............240

- for wind-breaks............... 89

- how to pick ...................... 384

- species of .................. 3

Aralia, growth of ...............166

Arbor vitæ for wind-breaks . . . . . 89

Arbutus ..................... 5

Arizona...................... 9

Arsenie, arsenites ...........370-377

Artocarpus ................. 3

Aslies, mounds of ...............295

Asimina ..................... 4

Aspeet $. \ldots \ldots \ldots \ldots \ldots \ldots \ldots \ldots \ldots, 60$

Associations, shipping..........471

Atmospheric drainage ..........48-59

Auction sales .....................464

Audibert system................117

Authors on wind-breaks........... 71

Bacterial diseases .................349

Bagging fruit.................... 353

Banana .................... 7

- zone....................... 8

Barbadoes gooseberry ........... 7

Bark-bound trees...............285

Barley for cover.............192, 202

Barnett, quoted.................474

Barnyard manure .............211

Barrel presses ..................433

Barrenness of orchards ...........342

Barry, quoted.................. 72

- W. C., quoted ................. 33

Barton, H. L., quoted ...........154

Baskets......................417

Basswoods for wind-breaks....... 89

Batting berries ..................... 395

Beach, S. A., quoted...228, 230, 301, 334

Beans in orchard ........187, 192, 202

Beckwith on preserving fruits . . . . 440

Bellet, Du, on preserving.........458

Ben Davis apple, region for.......226

Benedict, mentioned...............396

Berberis, growth of................. 166

Berries, keeping................444

- packing .......................406

jorry stands .................386
Betulas, growth of...............166

Birds, protecting from...........296

- migrations of . . . . . . . . . . . 127

Blackberries, age for setting.......233

- and rust..................... 78

- distance for .................241

- laying down.................. 98

- mulehing................... 93

- on low lands ................ 59

- species of $\ldots \ldots \ldots \ldots \ldots \ldots \ldots \ldots \ldots 6$

- thinning ........................ 305

- tilling .....................281

- when to pick ................279

Blackberry flowers, killed .........323

Black-knot ................... 22

Blodgett, quoted................ 80

Blossoms, effect of rain on..........333

Body-blight..................287

Bone..................27, 218

Boneblack ....................217

Books for record................. 307

Bordeaux mixture, formula........3\%1

- - for wounds............287, 31 !

Borers in grass lands.............172

- keeping out ................. 995

Boussingault, quoted............115

Box-scraper...................28i

Bramble-fruits................ 6

Bread-fruit .................. 3

Bread-stuffs, raising of.......... 26

Bridgeman, quoted ............ 72

Buckwheat for cover ..........191, 202

Budding young stocks ............235

Budd, quoted .................. 51

Bud-moth ........................ 369

Buds, winter-killing of ........316, 321

Buffalo berries, mulehirg ........ 93

- berry....................... 6

Bug, what is a ................ 25

Buildings for storage . . . .426, 436, 444

Burrill, quoted.................281

Bush-fruits, defined.............. 6

Butternut..................... 4

Buying trees.................. .235

California, frost $\ldots \ldots \ldots \ldots \ldots \ldots \ldots 12$ 
California fruits, packing...........410

Cherry-culture, status of............137

- shipping from...................468

- spraying for frost............106, 110

- wind-breaks in............ $76,77,89$

Canada, frosts..................... 43

Cane-fruits ....................... 6

Canker-worm...................78, 369

Canned goods..................... 32

Caraunda ........................ 6

Carbolic soap.....................285

Carbonate copper...................369

Card, F. W.......................305

- ón rain.........................339

Carica .......................... 5

Carissa............................. 6

Carob............................ 4

Carolinas, frost..................125

Carpinus, growth of ...............166

Cars, refrigerator..................466

Caryas, growth of ................167

Cashew ......................... 5

Casimiroa....................... 3

Castaneas, growth of..............167

- species of ..................... 5

Catalpa, growth of.................167

Catch erops....................164, 184

Cedar-apples...................... 78

Celery, keeping................444, 445

Cellars........................436, 438

Celtis, growth of..................167

Ceratonia....................... 4

Cereis, growth of .................167

Ceriman ........................ 7

Chart of frost....................126

Chautauqua.................41, 42, 52

- freeze ..........................327

Chemical fertilizers................212

Cherimoya....................... 4

Cherries and birds................296

- distance for.................240, 273

- how to pick ......................384

- keeping.....................397, 444

- shaking off......................395

- species of..................... 3

- when to pick...................382

Cherry-knot ..................... 22

Cherry, Surinam ................ 4

- trees in Virginia ...............243

Chestnuts for wind-breaks......... 89

- species of ................... 5

Chieago, market of ................474

Chill room.......................436

Chinquapin ................... 5

Chrysophyllum .................. 4

Cions, selection of ................234

Citron .......................... 3

Citrous fruits.................... 3

- groves, frosts ..................107

- zone......................... 8

Citrus, species of ................. 3

Cladrastis, growth of..............167

Clinton, L. A., quoted .............145

Clod-crushers......................157

Clouds and frost...................111

Clover, analysis of................202

- Crimson.........164, 190, 199, 202, 218

- for orehards ................189, 202

Coccoloba........................ 5

Cocoa-nut........................ 5

- zone......................... 8

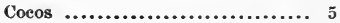

Codlin-moth..................369, 370

- distribution of .................20, 24

Cold, injuries by................... 313

Cold-storage.................455, 438

Cold, what is injurious ............329

Coloring baskets..................416

Commercial fertilizers on hard

lands ........................141

Complete fertilizers ...............216

Connecticut peach orchards .......272

- peach trees in ....................243

- temp. in........................ 80

Constitutional diseases.............349

Consumer, reaching the............461

Cook, A. J., quoted .................344

Cook's apple picker.................394

Coote on pollination................340

Copper earbonate formula..........369 
Corn for cover...............191, 202

- orchards ..................170

- marker.....................265

Cornus, growth of ..............167

Corylus.................... 5

Cosmopolitan fruits............9, 19

Cover crops..................164, 184

Covering plants................ 98

Cow peas, analysis of . . . . . . . . 202

- in orchard ............187, 192, 202

Crab-apples, species of........... 2

Craig, John, quoted.............275

Cranberries, distance for . . . . . . . 241

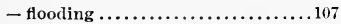

- keeping ......................444

- picking .....................400

- sorting ......................433

Cranberry, inventory of $\ldots \ldots \ldots \ldots, 7$

Cratregus, growth of ............. 167

Crates ........................4.

- for picking..................389

Crimson clover....164, 190, 199, 202, 218

- - analysis of ...............202

Cropping the orchard.............170

Cultivators .......................

Curculio machine.................395

Currants, age for setting.........233

- distance for..................241

- mulching.................. 93

- shaking off....................... 395

- species of $\ldots \ldots \ldots \ldots \ldots \ldots \ldots \ldots 6$

- thinning .......................303

Currents of air vs. frost...........119

Cyphomandra ................ 7

Cypress for wind-breaks ........ 89

Dakota, frost.................112

Date......................... 5

Dates, keeping...................4t4

Davies, D. O., quoted..............120

Deciduous zone................. 8

Delaware, fruit trees in . . . . . . . . 243

Determinate growth..............164

Dewberries and rust............. 78

- species of................... 6

Dew-point, determining.......130, 131
Dew-point, raising............. 54

Diospyros, syecies of............ 4

Discovery..................... 26

Diseases .............................

Distance for planting.........239, 273

Distribution ..................461

- of products.................. 34

Dolichos sesquipedalis.............194

Double planting .................241

Downing, quoted................ 71

- storage house................445

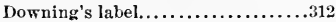

Drags..................... 149, 150

Drainage ..................... 154

- atmospheric ...............48,51

Dried fruits, keeping ............444

Droughts ..................... 142

Drupaceous fruits ............. 3

Dry freezing.................. 10

Du Bellet, on preserving..........458

Duggar, B. M., on storage .........445

Dutton, A. H., spraying rig.........357

Dwarfs vs. standards ............203

Earle, F. S., on shipping.........467

- Parker...................269, 270

Ebenaceous fruits............... 4

Egg-cases . . . . . . . . . . . . . . 424

Elæagnus................... 6

Elevation and frost......41,44,55, 58

Elms for wind-breaks ........... 89

Emulsion formula ................. 369

Eriobotrya................... 2

Eucaly ptus for wind-breaks....... 89

Eugenia, species of ........... 4

Euonymus, growth of............167

Europe, smudges in..............114

Evans, J. C., mentioned ...........2\%

Evaporated fruits, keeping ........444

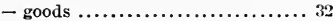

Evaporation in winter........... Io

Evolution of fruit-region ........ 26

Excommunication of bugs........ 25

Exploration ................... 26

Exporting apples ..............4409

Exposure..................59, 60 
Facing barrels....................407

Fagus, growth of ................167

Fairchild, quoted..............229, 334

Fall planting .....................237

- plowing........................144, 169

Family fruit garden.................276

Fernald, C. H., quoted.............. 23

Ferrocyanide tests.................372

Fertile varieties................227, 229

Fertility and produetiveness.........343

Fertilizers ......................202

Fertilizer summary...............219

Fertilizing........................175

Fiens ........................... 3

Fig.............................. 3

- Indian.......................... 7

- zone............................ 8

Figs, distance for................240

- for wind-breaks ............... 89

- keeping ........................444

- laying down.................... 98

Filbert.......................... 5

Finkle, quoted...................110

First-elass fruits..................401

- tree...........................231

Float ...........................153

Flooding for frost .................. 106

Florida freeze .................... 39

- freezes .........................120

- zones.......................... 8

- wind-breaks in ...............77, 89

Flowers, injury by cold.............322

- sterile.........................227

Fogs and frost...................111

Forest conditions..................134

Forests and fruit-growing.......... 77

Fragaria, species of............... 7

France, smudging in..............114

Fraxinus, growth of ...............167

Freezes ......................... 39

Frost, injurious degree of...........329

- prediction of .....................121

- protection from................ 92

Frosts and location............... 39

Frozen trees ......................314
Fruit-bnds, winter-killing ..........s16

Fruit, definition of ............... 1

- market, illustration of..........473

Fruit-pickers ....................392

Fruit-rot........................383

Fruit trees, plant-food in ..........204

Fruit-zones .......................7, 8

Fuller, quoted ................... 74

Fulton, quoted................... 73

Fungi and fruit-growing............ 21

- attacks by .......................349

Galloway, quoted..............106, 112

Galls on roots......................351

Garden and Forest, quoted .........179

Garey, quoted.................... 77

Genesee Fruit Company ............444

Geographieal adaptations..........226

Geography of fruit-growing........ 7

Georgia, frost....................125

- packing in.................431, 432

- peach orchards.................272

Germany, fruits in................411

- smudging in....................115

Gift package.......................416

Ginkgo ........................ 5

Gipsy-moth ..................... 24

Girdled trees ....................288

Girdling .......................288

Gleditschia, growth of..............167

Gluts ............................ 34

Glyeosmis ....................... 3

Goodman, L. A., mentioned ........270

Gooseberries, age for setting .......233

- shaking off ......................395

- species of .................... 6

Gooseberry, Barbadoes ............ 7

- effect of mulehing............... 93

- Otaheite.......................... 5

Goumi.......................... 6

Grading fruit.................401, 403

Grafting, top.....................298

- young stocks...................235

Grain in orchards.................170

Granadilla........................ 6

Grape business, status of.........32. 35 
Grape fruit $\ldots \ldots \ldots \ldots \ldots \ldots \ldots \ldots \ldots, 3$

- houses .......................425

- root, broken .................279

- trimming young................252

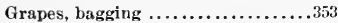

- distance for..................2

- how to pick ....................... 384

- injury by cold................327

- keeping ..............397, 413,444

- mulching..................... 93

- packing.................406, 429

- preserving ..............459,460

- rain on blossoms................336

- ringing.....................290

- species of $\ldots \ldots \ldots \ldots \ldots \ldots \ldots \ldots, 6$

-sterile and fertile...............230

Grazing...................... 26

Green, quoted................... 75

- manures ......................184

Ground bone....................218

Growing parts, injury to...........322

Growths, records of...............165

Guava, species of .............. 4

Gurney, quoted ............... 75

Hail injuries..................... 352

Hair, Uriah, mentioned............396

Hale, J. H., mentioned. ....259, 271, 273

- orehards, packing in............432

Halstead, B. D., quoted............303

- on rain.......................338

- on winter-killing..............318

Hammon, W. H., quotedi.. 107, 112, 120, 130,329

Hand-picking..................401

Hansen, N. E., quoted ........... 51

- on sun-scald..................284

Hardiness and moisture.........11, 18

Hard-pan................143, 155

Harness, Sherwood..............159

Harrowing.................149, 157

Hartlib, Samuel, quoted ...........142

Hawes, B. F., quoted ...............325

Hay in orchards ............... 170

Hexagonal plan.................265

Heading-in .......169, 240, 293, 315, 341
Heating the air .................120

Héguilus, quoted ................115

Hemlock for wind-breaks.......... 89

Herb-like fruits................ 7

Hessian-fly................... 24

Hexamer, on storing.............442

Hickories, speries of ............. 4

Hicoria, species of............. 4

Hide-bound trees................286

High lands.................... 59

Hiles, T. L., Ice book..............443

Hogs in orchards ...............173

Holes for trees.................24t

Home plantation................275

Horn-fly .................... 25

Hovenia ...................... 5

How to plant ...................244

Humus ............141, 179, 218, 221

Hunting ..................... 26

Husmann, quoted...............74

Ice storage...................435

Illinois, frost in ................... 332

Illustration of a market ..........473

Impotent varieties...........227, 229

Inarching...................289

Indeterminate growtl $\ldots \ldots \ldots \ldots \ldots . .165$

Indian fig.................... 17

Insects and fruit-growing........ 20

- attacks by ...................348

Insurance, spraying is............354

Irrigating for frost $\ldots \ldots \ldots \ldots \ldots 106,107$

Isophenal lines................. 128

Isoproetals................. 9

Isotherms $\ldots \ldots \ldots \ldots \ldots \ldots \ldots \ldots \ldots 9,128$

Ithaca, temperatures at......... 56

Jellies ........................ 32

Jew plum.................... 4

Juglans, species of ............. 4

Jujube $. \ldots \ldots \ldots \ldots \ldots \ldots \ldots \ldots \ldots, 5$

Juneberries, mulching.......... 93

Juneberry..................... 6

Kainit.................215, 217

Kaki...................... 4

- distance for .................240

Kansas, protecting peaches in ......101 
Kedzie on frosts ...................108

Loomis, quoted................... 80

- on psyebrometer.................128

Loquat ........................ 2

Keeping fruit ............397, 435, 444

Kenrick, quoted .................. 71

Kerosene emulsion, formula.........369

Kerr, J. W., quoted................229

Kieffer pear, region for............226

King, quoted .................48, 146

Kinney, T. L., storage house ........448

Knisely, A. L., quoted ............. 13

Knots on roots....................351

Kühnne-Rixdorf, B. L., quoted .......412

Kumquat ........................ 3

Labels ...........................307

Ladders............................390

Lagrolet system.....................117

Lakes and frosts.................42, 60

Larch for wind-breaks............ 89

Latitude........................ 9

- and fruit trees...............243, 265

Laws for pests.................. 22

Laying down plants............98, 99

- out the plantation................254

Leguminous fruits................. 4

Lemon.......................... 3

Lemons, distance for ..............241

- keeping ........................444

Lestout, on frosts .............116, 117

Lichen, office of .................176

Lime.........................3, 218

- arsenite of ......................377

- berry.......................... 3

- Spanish...................... 5

Line, laying-ont by ............259, 260

Lining packages ..................413

Lippens, on frost .................115

Liquors........................ 32

Liriodendron, growth of............167

Litchi.......................... 5

Location for fruit-growing......... 37

Locnst for wind-breaks............ 89

Lodeman, on nitrogen ..............214

- quoted ..........................234

Lodeman's label...................312

London purple, formula ............371

Low lands ..................... 59

Lucuma ......................... 4

Lumbering ..................... 26

MacGillirray, A. D., quoted..........121

McClner, G. W., quoted.............332

Maclura, growth of ...............167

Macomber, J. T., quoted............100

Magnolia, growth of...............167

Maine, frost ....................125

Mammea....................... 5

Mammee apple.................... 5

Mango ........................., 4

- zone......................... 8

Manitoba, frost..................112

- wind-breaks................... 51

Manufactured goods............... 32

Manure..........................211

Mangifera....................... 4

Maples for wind-breaks..........87, 89

Maps for orchards................307

Market, illnstration of.............473

- location ....................... 38

Markets and picking ...........379, 385

- finding ........................461

Marking out the area.............254

Marmalade tree ................... 4

Maryland law ................... 22

Maturity of fruits................279

Medlar......................... 2

Melicocca ....................... 5

Mespilus....................... 2

Mice, protecting from .........283, 294

Michigan ...................... 20

- fruit trees in................243, 265

- peaches in...................... 45

- planting in.....................260

- temp. in....................... 81

- wind-break in.................. 88

- wind-breaks in..............66, 70

Middleman........................464

Millet for cover................192, 202

Mining......................... 26

Missonri, fruit trees in.............243 


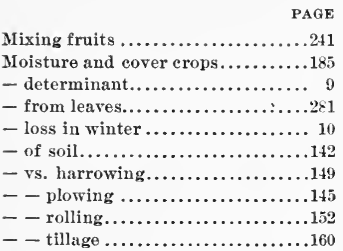

Monstera ..................... 7

Moore, quoted ................. 77

Moraceous fruits ............... 3

Morus, speeies of .............. 3

Mountain ash as stoek........... 19

Mulberry, species of ............ 3

Mulehing for frost.............. 92

Mulch of earth ................. 145

Mulching trees...................245

Muriate of potash........215, 217, 218

Musaceous fruits ............... 7

Musa, species of $\ldots \ldots \ldots \ldots \ldots \ldots \ldots 7$

Myriea..................... 5

Myrtaceous fruits.............. 4

Neetarine, kinds of ............. 3

Neetarines, distance for ..........240

Neetarine tree, exp. with......... 96

Neighborhood storage...........436

Nematode...................... 21

Nematodes.......................351

Nephelium................... 5

Netting about trees...........283, 295

- for birds ..................296

New England, trees in ............243

- Hampshire, frost . . . . . . . . . . 125

- Jersey, expts. in ..............210

- Mexico ..................... 9

- York, frost....................

- - frosts ....................4 43

- - fruit trees in ................265

- - peaches in................. 44

- temp. in.................. 81

- - wind-breaks in..........64, 69

Nitrate of soda .........213, 217, 218

Nitrogen, amount of............203
PAGE

Nitrogen for fruits..............?

North Carolina, planting in........261

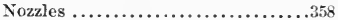

Nubbins of strawberries...........323

Nucieulture.................. 4

Nursery lands....................

Nurseryman, business of ........231

Nursery stock, injury by cold.......315

- - in orehards................ 170

Nut-fruits, kinds of............. 4

Nuts, keeping...................44t

Oats for eover...............192, 202

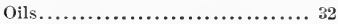

Olden plan................ 270, 272

Old orchards, renovating ..........340

Olea ........................ 5

Olive........................ 5

- zone...................... 8

Opuntia, species of $\ldots \ldots \ldots \ldots \ldots \ldots 7$

Orange groves, wind-breaks for .... 90

- soils for.................... 19

Oranges, distance for............241

- keeping ....................44t

- species of .................... 3

Orehard culture ................ 2

- definition of................. 2

- plans......................265

Orehards, renovating ..............340

Oregon ........................ 20

Organization..................

Osage orange for wind-breaks...... 89

Otaheite gooseberry............. 5

Outlook for fruit-growing......... $2 \overrightarrow{7}$

Over-production ................ 34

Ozark region....................

Pacifie zones...................8, 9

Packages.......................415

- small and large................465

Pucking grapes .................429

- houses.......................425

- how to .......................406

- of fruit......................401

Paddoek's label........................

Paint for wounds............287, $\$ 14$

Palmaceous fruits ............. 5 
Palmetto for wind-breaks ........ 90 rapaw........................4, 5 raper on fruits .................413 - tarred.......................295

Parasite determinant............21 Parasites and produetiveness.......343

Parentage of trees...............234

Paris green, formula...............371

- - tests for ...............372, 374

Passiflora...................... 6

Passifloraceous fruits ........... 6

Pasturing orchards ...............172

Peach buds, killed............319, 321

- culture, status of...............138

Peaches, age for planting..........233

- among apples...............241, 242

- distance for...............240, 273

- how to piek .................... 384

- keeping.................297, 444

- mulehing...................... 93

- packing ......................4406

- picking.........................388

- thinning.................300, 306

Peach-growing and frost...........125

- status of .....................44

Peach, soils for .................. 19

- species of .................... 3

- trees, and latitude ............243

- - fertilizing ..................210

- - nitrogen on................212

- price of......................236

- - protecting.................100, 101

- trimming young ......247, 248, 253

- when to pick....................382

- yellows.................22, 4i, 350

- zone......................... 8

Pear, Alligator.................. 5

Pear-blight................287, 350

Pear buds, killing ............321, 325

- on mountain ash.............. 19

- prickly...................... 7

- roots .........................161

- trees, trimming young ...........249

Pears, age for planting............233

- distance for................240, 273
Pears, dwarf, age for planting......233

- - depth to set.................244

$-\sim \operatorname{good}$ stock.................232

- - picking......................390

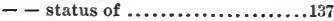

- hand-pieking................401

- how to pick ........................ 385

- injured by cold.................325

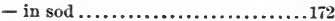

- keeping......................444

- packing .......................407

- preserving .....................459

- pruning Kieffer .................293

- rain on blossoms................334

- species of ..................... 2

- sterile and fertile ..............229

- when to pick....................380

- with peaches..................241

- wrapping....................413

Peas, analysis of . ...............201

- in orehards............187, 192, 202

Pecan......................... 4

Pecans, distance for ..............240

Peddlers .......................236

Pegging down trees.............. 98

Penicillium glaucum..............460

Pennsylvania, frost..............125

- fruit trees in..................265

Pepper tree for wind-breaks ....... 89

Pereskia....................... 7

Periearp ....................... 1

Perkins, C. H., on storage.........436

Persea ........................ 5

Persimmons, species of ...........4 4

Peru, smudging in...............116

Pests and fruit-growing .......... 20

Petit, A., preservative ............458

Petroleum for frosts. ..............112

Pettit, W. W., house of .......427, 430

Phenology .....................127

Philadelphus, growth of ...........167

Phin, quoted..................... 74

Phøenix ..................... 5

Phosphorie acid, amount of .......204

- - for fruits...................216 
PAGE

Phyllanthus................... 5

Phylloxera, flooding for...........107

Physiological diseases . . . . . . . . . 349

Pickers, keeping records with.......398

Pieking, how to do.................384

- when to do..................... 378

Pineapple.................... 7

- soils for.................... 19

Pineapples, covering.............106

Pines for wind-breaks.........89, 91

Pistacio...................... 5

Pistil, killing of................... 316

Place for fruit-growing . . . . . . . . 37

Plains region $\ldots \ldots \ldots \ldots \ldots \ldots \ldots \ldots, 9$

Planker.......................... 153

Plans for orchards...............265

Plantain ..................... 7

Plant, how to.....................244

Planting.....................224

Plants, ehoosing...............230

Platanus, growth of...............167

Pliny, on frosts .................114

Plow, handy..................281

Plowing vs. moisture .............145

Plow, laying-out by..............256

Plum buds, killing ............321, 325

- culture, status of..............137

— injured by hail................. 352

- Jew ...................... 4

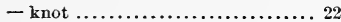

- on peach ...................... 19

Plums, age for planting...........233

- distance for . .............240, 273

- hand-picking ................401

- how to pick ........................ 384

- impotent................228, 229

- keeping .....................444

- species of .................... 3

- when to pick ....................382

Plum tree,.injured by cold..........315

- trees, price of .................236

- - trimming young.............251

Pollen and weather..............227

Pollination.....................227

- and rain.......................333
PAGE

Pomaceous fruits.............. 2

Pomegranate................... 5

- zone....................... 8

Pomelo ....................... 3

Pomology, definition of .......... 1

Pond-apple.................... 4

Pools .........................4

Poplars for wind-breaks........88, 89

Populus, growth of ...........167, 168

Potash, amount of..............204

- for fruits....................214

Potato and the bug ...............347

- beetle...................347, 369

Potato-bug..................... 25

Powell, G. T., quoted.............409

Prediction of frost ..............121

Preserving fruits . ..............258

Presses for barrels . ..............433

Price of stock .................236

Prickly pear ................. 7

Productiveness of orchards........343

Propagation and productiveness....343

Prophylaxis ....................350

Prune, distance for ..............273

Prunes, keeping .................444

Pruning and productiveness ........343

- trees.....................292, 300

- young trees .................246

Prunus, growth of...............168

- species of ................... 5

Psidium .................... 4

Psychrometer....................128

Puddling .....................246

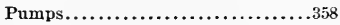

Punica...................... 5

Pyrus, growth of $\ldots \ldots \ldots \ldots \ldots \ldots . .168$

- speeies of ................. 2

Quantities of seed for cover crops...202

Quercus, growth of ............... 168

Quince-culture, status of..........137

Quinces, age for planting.........233

- and cedar-apples ............. 78

- distance for..................240

- keeping........................444

- low lands for................ 59 
Quinces, mulching.................93

- species of....................... 2

Quineunx system.............241, 265

Quinn, quoted.................... 74

Rabbits ....................283, 294

Rain, effect upon blossoms .........233

Raisins, keeping..................444

Rape for cover..................191

Raspberries, age for setting .......233

- and rust ...................... 78

- distance for....................241

- harvesting. .....................395

- kepeping ........................397

- laying down................... 98

- mulehing.......................93

- rain on.........................339

- species of ..................... 6

- thinuing........................305

- tilling.........................281

Raspberry, anthraenose ...........347

- galls on .......................351

Records of orchards...............307

Red-rust ....................... 78

Refrigerator ears ................466

Renovating orehards...............340

Repacking ......................441

Ribaceous fruits ................. 6

Ribes, growth of ..................168

- species of......................6 6

Rigs for spraying................356

Ringing......................290, 291

Ripeness........................279

Rivers and frosts................42, 60

Roberts on fertilizing orchards .....203

Rollers..........................152

Root.gall........................351

Root-knot ...................21, 351

Root-pruning .....................280

Roots, broken................279, 280

- extent of .......................161

- trimming......................246

Rose-apple........................4 4

Rose-chafer...................... 78

Roses, mulching .................. of

Rosette ......................... 22
Rosin, for freezes.................121

Rotation........................220

- and pests.......................347

Rows, making straight ............254

Rubaceous fruits ................. 6

Rubus, species of ................. 6

Rudisill, quoted .................. 76

Rural Life, quoted................ 51

Russia, laying down trees in........98

Rye .....................164, 190, 202

St. John's Bread.................. 4

Salix, growth of ..................168

San José scale ..................... 22

Sapodilla ....................... 4

Sapotaceons fruits................ 4

Sapota, white................... 3

Sances.......................... 32

Scab, apple..............347, 354, 369

Seale, San José.................. 22

Sehinus for wind-breaks........... 89

Seraping........................286

Screens as covers.................106

Sea-grape....................... 5

Seedlings, value as stocks...........235

Selection, influenee of ..............234

Self-sterile fruits .................229

Semi-tropical zone............... 8

Serres, on frosts..................114

Setting the plants.................224

Shaddock....................... 3

Shaking off fruits ..............395, 401

Sheds, for packing................432

Sheep, in orchards................173

Sheldon, S. L., quoted............. 56

Shelter belts..................... 87

Shepherdia ..................... 6

Shipping........................461

- associations....................471

Site.............................. 58

Slitting the bark.................286

Slopes .......................... 60

Small-fruit eulture, inventory of ... 6 - defined ....................... 6

Small-fruits in orchards ...........243

Smith, E. F., on nitrogen ..........212 
Smoking for frost

Strawberries, mulching.......... 95

Smudging for frost ...............111

- on low lands ............... 59

Snow, G. C., grapes ..........432, 443

Snows, utilizing ................149

Soap for trees ................285

Soda, arsenite of ............... 377

- nitrate of............213, 217, 218

Sod in orchards................

Soil determinant............... 18

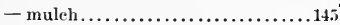

Sonoran zone................. 9

Sorting-tables ................433

Sour-sop..................... 4

South Carolina roek ..........216-218

Spalding, quoted............... 77

Speeulation.................. 26

Spondias..................... 4

Sprayed fruit ..................415

Spraying........................

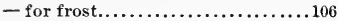

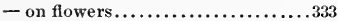

Spring planting. ................238

Sprinkling for frost............. 106

Spruces for wind-breaks........87, 91

Stable manure.................211

Staking out orchards............261

- trees ......................282

Standards vs, dwarfs............233

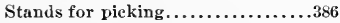

Star-apple ................... 4

Sterile varieties ............227, 229

Stevens, H. R., quoted.............120

Stoek, first-elass................231

- proteeting from..............296

Stoek-raising ................. 26

Stocks vs. soils ................ 19

Stone fruits.................. 3

Storage houses..........426,436,444

Storing fruits...............435, 438

Strawberries, age for setting ......233

- eovering .................98, 106

- distance for..................241

- how to piek ............................

- in orchards ..................243

- keeping ......................... 397

- species of $\ldots \ldots \ldots \ldots \ldots \ldots \ldots \ldots, 7$

- sterile and fertile .............230

- when to pick.................279

Strawberry diseases .............78

- field and frost............... 53

- flowers and weather...........227

- is cosmopolitan .............. 9

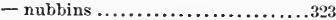

- rust ......................... 347

- tree ...................... 5

Stringfellow system.............246

Stripping trees..................238

Strong, quoted................ it

Subsoiling .......................... 155

Substitution ..................237

Sugar-apple..................

Sulfato of potash..........215, 217

Sulfur for bleaching..............417

- test for Paris green ............... 37

Summer-fallowing orehards .......178

Sun-seald .....................282

Superphosphate ............216, 217

Surinam elierry............... 4

Surveying plantations ..........254

Sylvinit......................

Syringa, growth of ..............168

Tags for pickers .................. 398

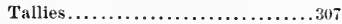

Tamarind................... 4

Tamarindus ................. 4

Tangierine.................... 3

Tare for eover ................... 195

Tarred paper...................295

Tarr, R. S., quoted............42, 52

Teller, analysis by..............201

Temperate zone................ 8

Temperature determinant ......... 8

Temperatures for fruits...........444

Tennessee frost................ 125

Tent-caterpillar...................869

Tent-caterpillars............... 78

Terminalia.................... 5

Texas, fruit trees in............. 43 
Texture of soil..................140

Thermometer, wet- and dry-bulb . 128

Thinning fruit ..... . . 299

Thomas, quoted ....... 72

Thorn trees and cedar-apples. . . . 78

Tickets for pickers. . . . . . 398

Tilia, growth of. . . . . . 168

Tillage .

133,277

- and productiveness ...... 243

- philosophy of ........ 138

- value of ............ 139

Tilling for frost . . . . . . 109

-suggestions for. . . . . . 154

Time to plant. . . . . . . . 237

Top-grafting . . . . . . . . 298

Trade-mark.......... 414

Transpiration from leaves . . . . 281

Transportation ......... 466

- facilities......... 38

Trays for picking. . . . . 386

- keeping fruit on . . . . . . 441

Tree, first-class. . . . . . 231

Tree-fruit culture... . . . . 2

Trees, choosing. . . . . . 230

Trifolinm incarnatum ..... . 202

Trimming trees........ 292

- young trees........ 246

Triphrasia.......... 3

Troop, James, quoted. . . . . . 296

Tropical zone......... 8

Turner, E. T., quoted . . . . 40.

Turnips for cover ..... 191, 202

Twigs, moisture in ....... 10

Tying trees. . . . . . . . 282

Umbrellas as fruit-pickers . . . 395

Unions .......... 472

United States, fruit in . . . . . 35

Unventilated crates. . . . . . 397

Vaccininm ......... 7

Van Deman plan . . . . . . 265

- quoted ..... 242, 256, 265

Vapor, alcoholic, as preservative ...458

- and frost....... . 106

Varieties and productiveness. . 243

- choosing.
Varieties running out ..... 225

Vegetables, keeping. . . . . . 444

Vermin, protecting from. . 283, 294

Vermont, frost.. . . . . . 125

- storage house .......446

- wind-breaks in....... 73

Vetch, analysis of. . . . . . 201

- in orchard...... 187, 195, 202

Vicia sativa. . . . . . . 197

Vigna Sinensis . . . . . . . 192

Vine-fruit culture....... 5

Vineyard label . . . . . . . . 312

Vineyards, status of ...... 137

Virginia, frost........12t

- fruit trees in........ . 243

- storage house . . . . . 452

Viticulture, inventory of . . . . 5 5

Vitis, growth of ...... 168

- species of ... . . . 5, 6

Voorhees, E. B., quoted . . 207, 210, 217

Wagonis for picking. . . . . . . 389

Waite, M. B., quoted . . . . . 228, 229

Walnuts for wind-breaks . . . . . 89

- species of. . . . . . . . . 4

Warder, quoted. . . . . . . 71

Washington, quoted ...... 24

Washing trees . . . . . . 285

Water and frosts. . . . 42, 60

- in air. . . . . . . 106

Watermelons, keeping .... 444

Wangh, on storing apples. . . . 446

- quoted... ...... 73

Wealth of farmer. . . . . . 28

Weather vs. pollen-bearing . . . . 227

Weeds....... 136, 177, 278

Wellhouse orchards . . . 259, 268

West Virginia, frost . . . . . 125

Wet- and dry-bulb. . . . . 128

Whale-oil soap ...... 285

Wheat, constituents of...... 206

- fields, frost in . . . . . 112

- for cover. . . . . . . 192, 202

Whitten, quoted........ 92

Wickson, quoted ....... 76

Willows for wind-breaks... . . 89 
PAGE
Wilson, on thinning apples . . . . 302

Wind-breaks........ 48,51

- discussion of. . . . . . . . 62

Winds and fruit.growing. . . . . 47

Wine, keeping . . . . . . . 444

Wine-making . . . . . . . . 32

Winter-killing of fruit-buds. . . . 316

- of wood . . . . . . . . . 313

Winter preparations . . . . . 294

- trimming ........254

Wire, laying-out by. . . . . . 260

- screen ........ 283, 295
PAGE

Wisconsin .......... 48

Women as packers . . . . . 405

Wrapping fruits . . . . . . 413

Yard manure . . . . . . . . 211

Yellows of peach . . . 22,47,350

Yeomans, spraying rig . . . . . 356

- T. G., quoted. . . . . . 261

- T. G. \& Sons, on wind-breaks.. 84,86

Zine labels . . . . . . . . . 308

Zizyphus........... 5

Zones, of fruit . . . . . . 7.8 


\section{The Best and Nervest Rural Books}

ROOKS ON LEADING TOPICS CONNECTED WITH AGRICULTURAL AND RURAL LIFE ARE HERE MENTIONED. EACH BOOK IS THE WORK OF A SPECIALIST, UNDER THE EDITORIAL SUPERVISION OF PROFESSOR L. H. BAILEY, OF THE CORNELL UNIVERSITY, OR BY PROFESSOR BAILEY HIMSELF, AND IS READABLE, CLEAR-CUT AND PRACTICAL. 


\section{THE RURAL SCIENCE SERIES}

Includes books which state the underlying principles of agriculture in plain language. They are suitable for consultation alike by the amateur or professional tiller of the soil, the scientist or the student, and are freely illustrated and finely made.

The following volumes are now ready:

THE SOIL. By F. H. Kine, of the University of Wisconsin. 303 pp. 45 illustrations. 75 cents.

THE FERTILITY OF THE LAND. By I. P. RoBERTS, of Cornell Univer* sity. Fifth edition. 421 pp. 45 illustrations. $\$ 1.25$.

THE SPRAYING OF PLANTS. By E. G. Lodeman, late of Cornell Lniversity. $399 \mathrm{pp}$. 92 illustrations. $\$ 1.00$.

MILK AND ITS PRODUCTS. By H. H. WING, of Cornell University. Fifth edition. 311 pp. 43 illustrations. \$1.00.

THE PRINCIPLES OF FRUIT-GROWING. By L. H. BAILEY. Fourth edition. $516 \mathrm{pp} .120$ illustrations. $\$ 1.25$.

BUSH-FRUITS. By F. W. CARD, of Rhode Island College of Agrieulture and Mechanic Arts. Second edition. $537 \mathrm{pp.} 113$ illustrations. \$1.50.

FERTILIZERS. By E. B. Voorhess, of New Jersey Experiment Station. Third edition. 332 pp. $\$ 1.00$.

THE PRINCIPLES OF AGRICULTURE. By L. H, BAILey. Third edition. $300 \mathrm{pp} .92$ illustrations. $\$ 1.25$.

IRRIGATION AND DRAINAGE. By F. H. King, University of Wisconsin. $502 \mathrm{pp} .163$ illustrations. $\$ 1.50$.

THE FARMSTEAD. By I. P. ROBERTS. 350 pp. 138 illustrations. $\$ 1.25$.

RURAL WEALTH AND WELFARE. By GEORGE T. FAIRChILd, Ex-Presi. dent of the Agricultural College of Kansas. 381 pp. 14 charts. \$1.25.

THE PRINCIPLES OF VEGETABLE-GARDENING. By L. H. BAILE. $468 \mathrm{pp}$. 144 illustratious. $\$ 1,25$.

THE FEEDING OF ANIMALS. By W. H. JordAN, of New York State Experiment Station. 450 pp. $\$ 1.25$ net.

FARM POULTRY. By George C. Watson, of Pennsylvania State College. 341 pp. $\$ 1.25$ net.

New volumes will be added from time to time to the Rural Science Series. The following are in preparation:

PHySiology OF PLANtS. By J. C. Arthur, Purdue University. BREEDING OF ANIMALS. By W. H. BREwer, of Yale University. PLANT PATHOLOGY. By B. T. GALLOWAY and associates of U. S. Depart. ment of Agriculture.

CARE OF ANIMALS. By N. S. MAYo, of Connecticut Agricultural College. THE POME FRUITS (Apples, Pears, Quinces). By L. H. BALLy. 


\section{THE GARDEN-CRAFT SERIES}

Comprises practical hand-books for the horticulturist, explaining and illustrating in detail the various important methods which experience has demonstrated to be the most satisfactory. They may be called manuals of practice, and though all are prepared by Professor BAILEY, of Cornell University, they include the opinions and methods of successful specialists in many lines, thus combining the results of the observations and experiences of numerous students in this and other lands. They are written in the clear, strong, concise English and in the entertaining style which characterize the author. The volumes are compact, uniform in style, clearly printed, and illustrated as the subject demands. They are of convenient shape for the pocket, and are substantially bound in flexible green cloth.

THE HORTICULTURIST'S RULE-BOOK. By L. H. BATLEY. Fourth edition. $312 \mathrm{pp} .75 \mathrm{cts}$.

THE NURSERY-BOOK. By L. H. BAILEx. Fifth edition. 365 pp. 152 illustrations. $\$ 1.00$.

PLANT-BREEDING. By L. H. BArLeY. 293 pp. 20 illustrations. $\$ 1.00$.

THE FORCING-BOOK. BY L. H. BAILEY. 266 pp. 88 illustrations. $\$ 1.00$.

GARDEN-MAKING. By L. H. Bailex. Fifth edition. 417 pp. 256 illustrations. $\$ 1.00$.

THE PRUNING-BOOK. By L. H. BArLey. Fourth edition. 545 pp. 231 illustrations. $\$ 1.50$.

THE PRACTICAL GARDEN-BOOK. By C. E. Hunn and L. H. Bailer. 250 pp. Many marginal ents. $\$ 1,00$. 


\section{THE SURVIVAL OF THE UNLIKE: 1 A Collection of Evolution Essays Suggested by the Study of Domestic Plants. By L. H. BAILEY, Professor of Horticulture in the Cornell University.}

FOURTH EDITION - 616 PAGES - 22 ILLUSTRATIONS - 32.00

To those interested in the underlying philosophy of plant life, this volume, written in a most entertaining style, and fully illustrated, will prove welcome. It treats of the modification of plants under cultivation upon the evolution theory, and its attitude on this interesting subject is characterized by the author's well-known originality and independence of thought. Incidentally, there is stated much that will be valuable and suggestive to the working horticulturist, as well as to the man or woman impelled by a love of nature to horticultural pursuits. It may well be called, indeed, a philosophy of horticulture, in which all interested may find inspiration and instruction.

The Survival of the Unlike comprises thirty essays touching upon The General Fact and Philosophy of Evolution (The Plant Individual, Experimental Evolution, Coxey's Army and the Russian Thistle, Recent Progress, etc.); Expounding the Fact and Causes of Variation (The Supposed Correlations of Quality in Fruits, Natural History of Synonyms, Reflectire Impressions, Relation of Seedbearing to Cultivation, Variation after Birth, Relation between Ameriean and Eastern Asian Fruits, Horticultural Geography, Problems of Climate and Plants, American Fruits, Acclimatization, Sex in Fruits, Novelties, Promising Varieties, etc.); ard Tracing the Evolution of Parsicular Types of Plants (the Cultivated Strawberry, Battle of the Plums, Grapes, Progress of the Carnation. Petunia. The Garden Tomato, etc.). 


\section{THE EVOLUTION OF OUR NA- TIVE FRUITS. By L. H. BAILEY, Pro. \\ fessor of Horticulture in the Cornell University.}

472 PACES - 128 ILLUSTRATIONS - 82.00

In this entertaining volume, the origin and development of the fruits peculiar to North America are inquired into, and the personality of those horticultural pioneers whose almost forgotten labors have given us our most valuable fruits is touched upon. There has been eareful research into the history of the various fruits, including inspection of the records of the great European botanists who have given attention to American economic botany. The conclusions reached, the information presented, and the suggestions as to future developments, cannot but be valuable to any thoughtful fruit-grower, while the terse style of the author is at its best in his treatment of the subject.

The Evolution of our Native Fruirs discusses The Rise of the American Grape (North America a Natural Vineland, Attempts to Cultivate the European Grape, The Experiments of the Dufours, The Branch of Promise, John Adlum and the Catawba, Rise of Commercial Viticulture, Why Did the Early Vine Experiments Fail ? Synopsis of the American Grapes); The Strange History of the Mulberries (The Early Silk Industry, The "Multicaulis Craze,"); Evolu. tion of American Plums and Cherries (Native Plums in General, The Chickasaw, Hortulana, Marianna and Beach Plum Gronps, Pacifio Coast Plum, Various Other Types of Plums, Native Cherries, Dwarf Cherry Group); Native Apples (Indigenons Species, Amelioration has begun); Origin of American Raspberry-growing (Early American History, Present Types, Outlying Types); Evolution of Blackberry and Dewberry Culture (The High-bush Blackberry and Its Kin, The Dewberries, Botanical Names); Various Types of Berry-like Fruits (The Gooseberry, Native Currants, Juneberry, Buffalo Berry, Elderberry, High-bush Cranberry, Cranberry, Strawberry); Various Types of Tree Fruits (Persimmon, Custard-Applo Tribe, Thorn-Apples, Nut-Fruits); General Remarks on the Improvement of our Native Fruits (What Has Been Done, What Probably Should Be Done). 


\section{ESSONS WITH PLANTS: Sugges- tions for Seeing and Interpreting Some of the Common Forms of Vegetation. By L. H. BAILEY, Professor of Horticulture in the Cornell University, with delineations from nature by W. S. HOLDSWORTH, of the Agricultural College of Michigan.}

\section{SECOND EDITION-491 PACES-446 ILLUSTRATION\$-12 MO- CLOTH-\$1.10 NET}

There are two ways of looking at nature. The old way, which you have found so unsatisfactory, was to classify everything-to consider leaves, roots, and whole plants as formal herbarium specimens, forgetting that each had its own story of growth and development, struggle and success, to tell. Nothing stifles a natural love for plants more effectually than that old way.

The new way is to watch the life of every growing thing, to look upon each plant as a living ereature, whose life is a story as fascinating as the story of any favorite hero. "Lessons with Plants" is a book of stories, or rather, a book of plays, for we can see each chapter acted out if we take the trouble to look at the actors.

"I have spent some time in most delightful examination of it, and the longer I look, the better I like it. I find it not only full of interest, but emimently suggestive. I know of no book which begins to do so much to open the eyes of the student-whether pupil or teacher - to the wealth of meaning contained in simple plant forms. Above all else, it seems to be full of suggestions that help one to learn the language of plants, so they may talk to him."-DARWIN L. BARDWELl, Superintendent of Schools, Bing. hainton.

"It is an admirable book, and eannot fail both to awaken interest in the subject, and to serve as a helpful and reliable guide to young students of plant life. It will, I think, fill an important place in secondary schools, and comes at an opportnne time, when helps of this kind are needed and eagerly sought."-Professor V. M. SPaldiNG, University of Michigan.

\section{FIRST LESSONS WITH PLANTS}

An Abridgement of the above. 117 pages-116 illustrations -40 cents net. 


\section{WORKS BY PROFESSOR BAILEY}

\section{ROTANY: An Elementary Text for Schools. By L. H. BAILEY.}

\section{PACES-500 ILLUSTRATIONS-\$1.10 NET}

"This book is made for the pupil: 'Lessons With Plants" was made to supplement the work of the teacher." This is the opening sentence of the preface, showing that the book is a companion to "Lessons With Plants," which has now become a standard teacher's book. The present book is the handsomest elementary botanical text-book yet made. The illustrations illustrate. They are artistic. The old formal and unnatural Botany is being rapidly outgrown. The book disparages mere laboratory work of the old kind: the pupil is taught to see things as they grow and behave. The pupil who goes through this book will nnderstand the meaning of the plants which he sees day by day. It is a revolt from the dry-as-dust teaching of botany. It cares little for science for science' sake, but its point of view is nature-study in its best sense. The book is divided into four parts, any or all of which may be used in the school: the plant itself; the plant in its environment; histology, or the minute structure of plants; the kinds of plants (with a key, and descriptions of 300 common species). The introduction contains advien to teachers. The book is brand new from start to finish.

"An exceedingly attractive text-book."-Educational Review.

"It is a school book of the modern methods."-The Dial.

"It would be hard to find a better manual for schools or for individual use."-The Outlook.

\section{THE MACMILLAN COMPANY}




\section{THE CYCLOPEDIA OF AMERICAN 1 HORTICULTURE : By L. H. BAILEY, of Cornell University, assisted by WILHELM MILLER, and many expert cultivators and botanists.}

4 VOLS.-OVER 2600 ORIGINAL ENGRAVINGS-CLOTH-OCTAVO \$20.00 NET PER SET

This great work comprises directions for the cultivation of horticultural crops and original descriptions of all the species of fruits, vegetables. flowers and ornamental plants known to be in the market in the United States and Canada. "It has the mique distinction of presenting for the first time, in a carefully arranged and perfectly accessible form, the best knowledge of the best specialists in America upon gardening, frnit-growing, vegetable culture, forestry, and the like, as well as exact botanical information. The contributors are eminent cultivators or specialists, and the arrangement is very systematic, clear and convenient for ready reference."

"We have here a work which every ambitions gardener will wish to place on his shelt beside lis Nicholson and his Loudon, and for sueh users of it a too advanced nomenclature would have been confusing to the last degree. With the safe names here given, there is little liability to serious perplexity. There is a growing impatience with much of the controversy concerning revision of names of organisms, whether of plants or animals. Those investigators who are busied with the ecological aspects of organisms, and also those who are ehiefly concerned with the application of plants to the arts of agrieulture, horticulture, and so on, eare for the names of organisms under examination only so far as these aid in recognition and identification. To introduce unnecessary confusion is a serious hlunder. Professor Bailey has avoided the risk of confusion. In short, in range, treatment and editing. the Cyclopedia appears to be emphatically useful; . . . a work worthy of ranking by the side of the Century Dictionary."-The Nation.

This work is sold only by subscription, and terms and further information may be had of the publishers.

\section{THE MACMILLAN COMPANY}

No. 66 Fifth Avenue

NEW YORK 
in 
. 



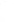


- 1 
USB IIRRARY

University of California

SOUTHERN REGIONAL LIBRARY FACILITY

405 Hilgard Avenue, Los Angeles, CA 90024-1388

Return this material to the library from which it was borrowed. 


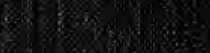

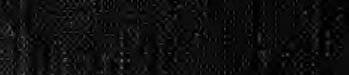

S.

sicis (4)

Singes

130.565

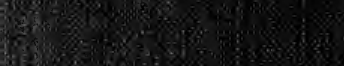

3 song

a)

How

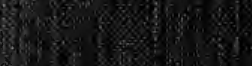

3. 3 (2)

(1)

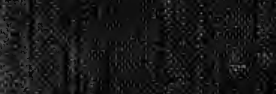

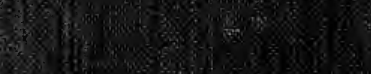

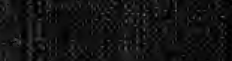

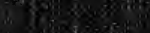

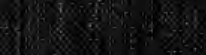

\%

ren

28.

(2)

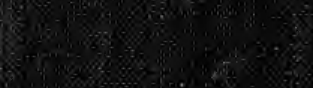
a.8. 